U.S. Department of the Interior

U.S. Geological Survey

\title{
Study Design and Analytical Results Used to Evaluate Stability of Volatile Organic Compounds in Water Matrices
}

By Jason T. Love', Gregory C. Delzer², Sonja R. Abney ${ }^{3}$, and John S. Zogorski ${ }^{2}$

Open-File Report 98-637

${ }^{1}$ Graduate Student, South Dakota School of Mines and Technology, Contract 1434-CR-96-AG-00773 ${ }^{2}$ U.S. Geological Survey, Rapid City, S. Dak.

3 U.S. Geological Survey, Arvada, Colo. 


\title{
U.S. Department of the Interior \\ Bruce Babbitt, Secretary
}

\author{
U.S. Geological Survey \\ Charles G. Groat, Director
}

The use of firm, trade, and brand names in this report is for identification purposes only and does not constitute endorsement by the U.S. Geological Survey.

Rapid City, South Dakota: 1999

For additional information write to:

District Chief

U.S. Geological Survey

1608 Mt. View Road

Rapid City, SD 57702

Copies of this report can be purchased from:

U.S. Geological Survey

Branch of Information Services

Box 25286

Denver, CO 80225-0286 
The mission of the U.S. Geological Survey (USGS) is to assess the quantity and quality of the earth resources of the Nation and to provide information that will assist resource managers and policymakers at Federal, State, and local levels in making sound decisions. Assessment of water-quality conditions and trends is an important part of this overall mission.

One of the greatest challenges faced by waterresources scientists is acquiring reliable information that will guide the use and protection of the Nation's water resources. That challenge is being addressed by Federal, State, interstate, and local water-resource agencies and by many academic institutions. These organizations are collecting water-quality data for a host of purposes that include: compliance with permits and water-supply standards; development of remediation plans for a specific contamination problem; operational decisions on industrial, wastewater, or watersupply facilities; and research on factors that affect water quality. An additional need for water-quality information is to provide a basis on which regional and national-level policy decisions can be based. Wise decisions must be based on sound information. As a society we need to know whether certain types of water-quality problems are isolated or ubiquitous, whether there are significant differences in conditions among regions, whether the conditions are changing over time, and why these conditions change from place to place and over time. The information can be used to help determine the efficacy of existing waterquality policies and to help analysts determine the need for and likely consequences of new policies.

To address these needs, the Congress appropriated funds in 1986 for the USGS to begin a pilot program in seven project areas to develop and refine the National Water-Quality Assessment (NAWQA) Program. In 1991, the USGS began full implementation of the program. The NAWQA Program builds upon an existing base of water-quality studies of the USGS, as well as those of other Federal, State, and local agencies. The objectives of the NAWQA Program are to:

- Describe current water-quality conditions for a large part of the Nation's freshwater streams, rivers, and aquifers.
- Describe how water quality is changing over time.

- Improve understanding of the primary natural and human factors that affect water-quality conditions.

This information will help support the development and evaluation of management, regulatory, and monitoring decisions by other Federal, State, and local agencies to protect, use, and enhance water resources.

The goals of the NAWQA Program are being achieved through ongoing and proposed investigations of 59 of the Nation's most important river basins and aquifer systems, which are referred to as Study Units. These Study Units are distributed throughout the Nation and cover a diversity of hydrogeologic settings. More than two-thirds of the Nation's freshwater use occurs within the 59 Study Units and more than two-thirds of the people served by public watersupply systems live within their boundaries.

National synthesis of data analysis, based on aggregation of comparable information obtained from the Study Units, is a major component of the program. This effort focuses on selected water-quality topics using nationally consistent information. Comparative studies will explain differences and similarities in observed water-quality conditions among study areas and will identify changes and trends and their causes. The first topics addressed by the national synthesis are pesticides, nutrients, volatile organic compounds, and aquatic biology. Discussions on these and other waterquality topics will be published in periodic summaries of the quality of the Nation's ground and surface water as the information becomes available.

This report is an element of the comprehensive body of information developed as part of the NAWQA Program. The program depends heavily on the advice, cooperation, and information from many Federal, State, interstate, Tribal, and local agencies and the public. The assistance and suggestions of all are greatly appreciated.

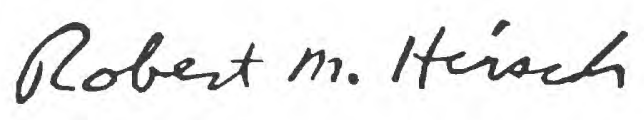

Robert M. Hirsch Chief Hydrologist 


\section{CONTENTS}

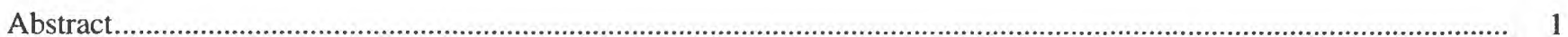

Introduction

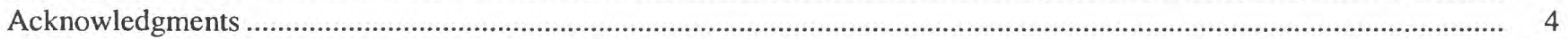

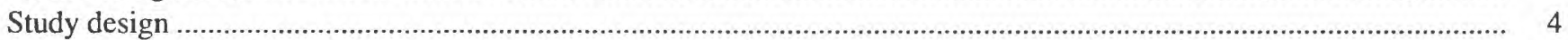

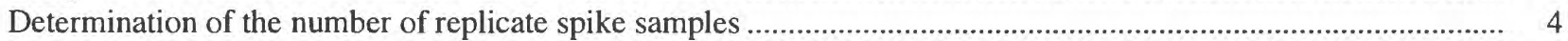

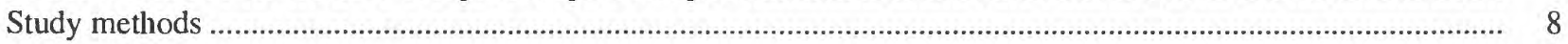

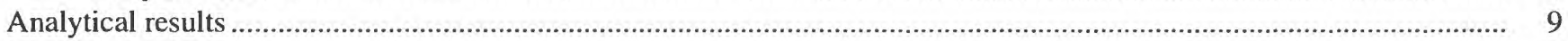

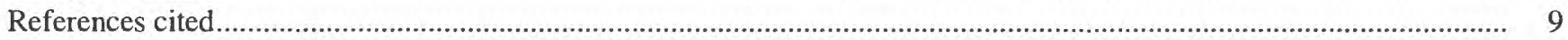

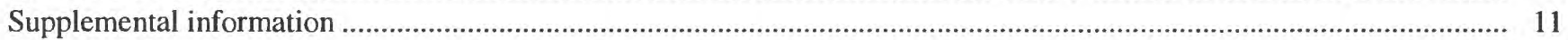

Analytical results for surface- and ground-water matrices.................................................................. 13

Plots of concentration data for volatile organic compounds in surface- and ground-water matrices

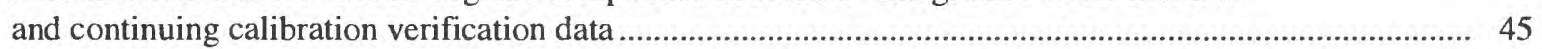

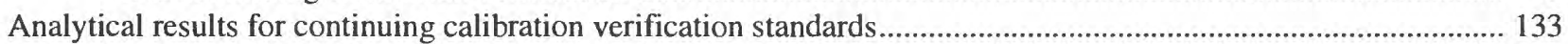

\section{TABLES}

1. Volatile organic compounds analyzed during this study

2. Summary statistics for 60 spiked reagent-water samples (set spikes) used to calculate the number of replicate spike samples needed to determine volatile organic compound (VOC) stability at the 99-percent confidence interval.

3. Number and percentage of volatile organic compounds (VOCs) that satisfy the conditions of equation 1 for assumed numbers of replicate spike samples

4. Concentrations of volatile organic compounds (VOCs) in surface- and ground-water matrices determined for stability study.

5. Percent-recovery data for continuing calibration verification standards (CCVs) for day 0 through day 216.

\section{CONVERSION FACTORS}

\begin{tabular}{rll}
\hline Multiply & By & To obtain \\
\hline liter $(\mathrm{L})$ & 0.2642 & gallon \\
microgram per liter $(\mu \mathrm{g} / \mathrm{L})$ & 1.0 & part per billion \\
\hline
\end{tabular}

Temperature can be converted to degrees Celsius $\left({ }^{\circ} \mathrm{C}\right)$ or degrees Fahrenheit $\left({ }^{\circ} \mathrm{F}\right)$ by the following equations:

$$
\begin{aligned}
& { }^{\circ} \mathrm{C}=\left({ }^{\circ} \mathrm{F}-32\right) / 1.8 \\
& { }^{\circ} \mathrm{F}=\left(1.8 \times{ }^{\circ} \mathrm{C}\right)+32
\end{aligned}
$$




\title{
Study Design and Analytical Results Used to Evaluate Stability of Volatile Organic Compounds in Water Matrices
}

\author{
By Jason T. Love, Gregory C. Delzer, Sonja R. Abney, and John S. Zogorski
}

\begin{abstract}
A surface- and a ground-water matrix were spiked with 87 volatile organic compounds (VOCs) to achieve a theoretical concentration of 0.5 microgram per liter for most VOCs. Five replicate spike samples from each water matrix were stored and analyzed at selected time intervals up to 216 days. To assess daily analytical variability, three replicate continuing calibration verification standards were analyzed at the same times as the spiked water matrices. The results of this study provide information about the stability of low concentrations of VOCs in water samples preserved with hydrochloric acid, chilled at 4 degrees Celsius, and kept in the dark prior to analysis. This report describes the study design and presents the results of samples analyzed on day $0,14,28,37$, $47,56,112,156$, and 216.
\end{abstract}

\section{INTRODUCTION}

Due to unforeseen technical difficulties with analytical equipment used for volatile organic compound (VOC) analyses at the U.S. Geological Survey (USGS) National Water-Quality Laboratory (NWQL) in Arvada, Colorado, approximately 150 to 200 VOC samples in the summer of 1996 exceeded the maximum U.S. Environmental Protection Agency (USEPA) preanalytical holding-time requirement of 14 days (Munch, 1995). The maximum holding time for the water samples that exceeded 14 days was 41 days, with a median holding time of 27 days. The samples were preserved in the field with hydrochloric acid (HC1), kept chilled at $4^{\circ} \mathrm{C}$, and analyzed as soon as the analytical equipment became operational. These data were subsequently released. However, the quality of the data was uncertain because little information exists on the stability of low concentrations of VOCs in water samples preserved with $\mathrm{HC} 1$ that are held beyond 14 days.

It is unknown how 14 days was chosen by the USEPA for a maximum pre-analytical holding time for VOC analysis. Maskarinec and others (1990) addressed the holding-time issue and suggested that the maximum holding time of VOCs in water could be increased to at least 56 days if the water samples are preserved with $\mathrm{HCl}$ to a $\mathrm{pH}$ of 2.0 or less and chilled at $4^{\circ} \mathrm{C}$. However, the concentrations of VOCs used in Maskarinec's preservation study, $100 \mu \mathrm{g} / \mathrm{L}$, were much higher than those found in most environmental samples collected by the USGS and submitted for analysis at the NWQL.

Water samples submitted to the NWQL during and after the timeframe that the 150 to 200 VOC samples exceeded the USEPA's holding time requirement were analyzed for 87 VOCs (table 1). The 87 VOCs were divided into two groups - target analytes (55 compounds) and other analytes ( 32 compounds). The target analytes were selected because of their known human-health and (or) aquatic-life concern or because of their high frequency of occurrence in surface and ground water (John Zogorski, USGS, written commun., 1994). The other analytes were included because they are on the USEPA's list for analysis using their revised method for drinking-water samples (Eichelberger and Budde, 1989). 
Table 1. Volatile organic compounds analyzed during this study

[Compounds are identified by the following: PCODE, U.S. Geological Survey data base parameter code; CAS no., Chemical Abstract Services number; IUPAC, International Union of Pure and Applied Chemistry]

\begin{tabular}{|c|c|c|c|c|c|}
\hline PCODE & CAS no. & $\begin{array}{l}\text { IUPAC compound name } \\
\text { (chemical formula) (common name(s)) }\end{array}$ & PCODE & CAS no. & $\begin{array}{l}\text { IUPAC compound name } \\
\text { (chemical formula) (common name(s)) }\end{array}$ \\
\hline \multicolumn{6}{|c|}{ Target analytes } \\
\hline 34030 & $71-43-2$ & Benzene $\left(\mathrm{C}_{6} \mathrm{H}_{6}\right)$ & 34541 & $78-87-5$ & $\begin{array}{l}\text { 1,2-Dichloropropane }\left(\mathrm{C}_{3} \mathrm{H}_{6} \mathrm{Cl}_{2}\right) \\
\text { (propylene dichloride) }\end{array}$ \\
\hline 32101 & $75-27-4$ & $\begin{array}{l}\text { Bromodichloromethane }\left(\mathrm{CHBrCl}_{2}\right) \\
\text { (dichlorobromomethane) }\end{array}$ & 34704 & $10061-01-5$ & $\begin{array}{l}\text { cis-1,3-Dichloropropene }\left(\mathrm{C}_{3} \mathrm{H}_{4} \mathrm{Cl}_{2}\right) \\
\quad((\mathrm{Z})-1,3 \text {-dichloropropene })\end{array}$ \\
\hline 50002 & $593-60-2$ & $\begin{array}{l}\text { Bromoethene }\left(\mathrm{C}_{2} \mathrm{H}_{3} \mathrm{Br} \text { ) }\right. \\
\text { (vinyl bromide) }\end{array}$ & 34699 & $10061-02-6$ & $\begin{array}{l}\text { trans-1,3-Dichloropropene }\left(\mathrm{C}_{3} \mathrm{H}_{4} \mathrm{Cl}_{2}\right) \\
\quad((\mathrm{E})-1,3 \text {-dichloropropene })\end{array}$ \\
\hline 34413 & $74-83-9$ & $\begin{array}{l}\text { Bromomethane }\left(\mathrm{CH}_{3} \mathrm{Br} \text { ) }\right. \\
\text { (methyl bromide) }\end{array}$ & 77135 & $95-47-6$ & $\begin{array}{l}\text { 1,2-Dimethylbenzene }\left(\mathrm{C}_{8} \mathrm{H}_{10}\right) \\
(\text { o-xylene })\end{array}$ \\
\hline 77342 & $104-51-8$ & $\begin{array}{l}\text { n-Butylbenzene }\left(\mathrm{C}_{10} \mathrm{H}_{14}\right) \\
\text { (1-phenylbutane) }\end{array}$ & 85795 & $108-38-3$ & $\begin{array}{l}\text { 1,3-Dimethylbenzene }\left(\mathrm{C}_{8} \mathrm{H}_{10}\right) \\
(m \text {-xylene }) \text { and }\end{array}$ \\
\hline 34301 & $108-90-7$ & $\begin{array}{l}\text { Chlorobenzene }\left(\mathrm{C}_{6} \mathrm{H}_{5} \mathrm{Cl}\right) \\
\text { (monochlorobenzene) }\end{array}$ & & $106-42-3$ & $\begin{array}{l}\text { 1,4-Dimethylbenzene }\left(\mathrm{C}_{8} \mathrm{H}_{10}\right) \\
(p \text {-xylene })\end{array}$ \\
\hline 34311 & $75-00-3$ & $\begin{array}{l}\text { Chloroethane }\left(\mathrm{C}_{2} \mathrm{H}_{5} \mathrm{Cl}\right) \\
\text { (ethyl chloride) }\end{array}$ & 77128 & $100-42-5$ & $\begin{array}{l}\text { Ethenylbenzene }\left(\mathrm{C}_{8} \mathrm{H}_{8}\right) \\
\text { (styrene) }\end{array}$ \\
\hline 39175 & $75-01-4$ & $\begin{array}{l}\text { Chloroethene }\left(\mathrm{C}_{2} \mathrm{H}_{3} \mathrm{Cl}\right) \\
\text { (vinyl chloride) }\end{array}$ & 50004 & $637-92-3$ & $\begin{array}{l}\text { 2-Ethoxy-2-methylpropane }\left(\mathrm{C}_{6} \mathrm{H}_{14} \mathrm{O}\right) \\
\text { (ethyl tert-butyl ether, ETBE) }\end{array}$ \\
\hline 34418 & $74-87-3$ & $\begin{array}{l}\text { Chloromethane }\left(\mathrm{CH}_{3} \mathrm{Cl}\right) \\
\text { (methyl chloride) }\end{array}$ & 34371 & $100-41-4$ & $\begin{array}{l}\text { Ethylbenzene }\left(\mathrm{C}_{8} \mathrm{H}_{10}\right) \\
\text { (phenylethane) }\end{array}$ \\
\hline 82625 & $96-12-8$ & $\begin{array}{l}\text { 1,2-Dibromo-3-chloropropane }\left(\mathrm{C}_{3} \mathrm{H}_{5} \mathrm{Br}_{2} \mathrm{Cl} \text { ) }\right. \\
\text { (dibromochloropropane, DBCP) }\end{array}$ & 39702 & $87-68-3$ & $\begin{array}{l}\text { 1,1,2,3,4,4-Hexachloro-1,3-butadiene } \\
\left(\mathrm{C}_{4} \mathrm{Cl}_{6}\right) \text { (hexachlorobutadiene) }\end{array}$ \\
\hline 32105 & $124-48-1$ & $\begin{array}{l}\text { Chlorodibromomethane }\left(\mathrm{CHBr}_{2} \mathrm{Cl}\right) \\
\text { (chlorodibromomethane) }\end{array}$ & 34396 & $67-72-1$ & $\begin{array}{l}\text { 1,1,1,2,2,2-Hexachloroethane }\left(\mathrm{C}_{2} \mathrm{Cl}_{6}\right) \\
\text { (carbon hexachloride) }\end{array}$ \\
\hline 77651 & $106-93-4$ & $\begin{array}{l}\text { 1,2-Dibromoethane }\left(\mathrm{C}_{2} \mathrm{H}_{4} \mathrm{Br}_{2}\right) \\
\text { (ethylene dibromide, EDB) }\end{array}$ & 50005 & $994-05-8$ & $\begin{array}{l}\text { 2-Methoxy-2-methylbutane }\left(\mathrm{C}_{6} \mathrm{H}_{14} \mathrm{O}\right) \\
\text { (tert-amyl methyl ether, TAME) }\end{array}$ \\
\hline 34536 & $95-50-1$ & $\begin{array}{l}\text { 1,2-Dichlorobenzene }\left(\mathrm{C}_{6} \mathrm{H}_{4} \mathrm{Cl}_{2}\right) \\
\text { (o-dichlorobenzene) }\end{array}$ & 78032 & $1634-04-4$ & $\begin{array}{l}\text { 2-Methoxy-2-methylpropane }\left(\mathrm{C}_{5} \mathrm{H}_{12} \mathrm{O}\right) \\
\text { (methyl tert-butyl ether, MTBE) }\end{array}$ \\
\hline 34566 & $541-73-1$ & $\begin{array}{l}\text { 1,3-Dichlorobenzene }\left(\mathrm{C}_{6} \mathrm{H}_{4} \mathrm{Cl}_{2}\right) \\
\text { (m-dichlorobenzene) }\end{array}$ & 34010 & $108-88-3$ & $\begin{array}{l}\text { Methylbenzene }\left(\mathrm{C}_{7} \mathrm{H}_{8}\right) \\
\quad \text { (toluene) }\end{array}$ \\
\hline 34571 & $106-46-7$ & $\begin{array}{l}\text { 1,4-Dichlorobenzene }\left(\mathrm{C}_{6} \mathrm{H}_{4} \mathrm{Cl}_{2}\right) \\
\text { (p-dichlorobenzene) }\end{array}$ & 77223 & $98-82-8$ & $\begin{array}{l}\text { (1-Methylethyl)benzene }\left(\mathrm{C}_{9} \mathrm{H}_{12}\right) \\
\text { (isopropylbenzene) }\end{array}$ \\
\hline 34668 & $75-71-8$ & $\begin{array}{l}\text { Dichlorodifluoromethane }\left(\mathrm{CCl}_{2} \mathrm{~F}_{2}\right) \\
\text { (CFC 12) }\end{array}$ & 34696 & $91-20-3$ & Naphthalene $\left(\mathrm{C}_{10} \mathrm{H}_{8}\right)$ \\
\hline 34496 & $75-34-3$ & $\begin{array}{l}\text { 1,1-Dichloroethane }\left(\mathrm{C}_{2} \mathrm{H}_{4} \mathrm{Cl}_{2}\right) \\
\quad \text { (ethylidene chloride) }\end{array}$ & 81577 & $108-20-3$ & $\begin{array}{l}\text { 2,2'-Oxybis[propane] }\left(\mathrm{C}_{6} \mathrm{H}_{14} \mathrm{O}\right) \\
\text { (diisopropyl ether, DIPE) }\end{array}$ \\
\hline 32103 & $107-06-2$ & $\begin{array}{l}\text { 1,2-Dichloroethane }\left(\mathrm{C}_{2} \mathrm{H}_{4} \mathrm{Cl}_{2}\right) \\
\text { (ethylene dichloride) }\end{array}$ & 34210 & $107-02-8$ & $\begin{array}{l}\text { 2-Propenal }\left(\mathrm{C}_{3} \mathrm{H}_{4} \mathrm{O}\right) \\
\quad \text { (acrolein) }\end{array}$ \\
\hline 34501 & $75-35-4$ & $\begin{array}{l}\text { 1,1-Dichloroethene }\left(\mathrm{C}_{2} \mathrm{H}_{2} \mathrm{Cl}_{2}\right) \\
\quad \text { (vinylidene chloride) }\end{array}$ & 34215 & $107-13-1$ & $\begin{array}{l}\text { 2-Propenenitrile }\left(\mathrm{C}_{3} \mathrm{H}_{3} \mathrm{~N}\right) \\
\text { (acrylonitrile) }\end{array}$ \\
\hline 77093 & $156-59-2$ & $\begin{array}{l}\text { cis-1,2-Dichloroethene }\left(\mathrm{C}_{2} \mathrm{H}_{2} \mathrm{Cl}_{2}\right) \\
\quad((\mathrm{Z}) \text {-1,2-dichloroethene })\end{array}$ & 77224 & $103-65-1$ & $\begin{array}{l}\text { n-Propylbenzene }\left(\mathrm{C}_{9} \mathrm{H}_{12}\right) \\
\text { (1-phenylpropane) }\end{array}$ \\
\hline 34546 & $156-60-5$ & $\begin{array}{l}\text { trans-1,2-Dichloroethene }\left(\mathrm{C}_{2} \mathrm{H}_{2} \mathrm{Cl}_{2}\right) \\
\quad((\mathrm{E}) \text {-1,2-dichloroethene })\end{array}$ & 34475 & $127-18-4$ & $\begin{array}{l}\text { Tetrachloroethene }\left(\mathrm{C}_{2} \mathrm{Cl}_{4}\right) \\
\text { (perchloroethene, } \mathrm{PCE})\end{array}$ \\
\hline 34423 & $75-09-2$ & $\begin{array}{l}\text { Dichloromethane }\left(\mathrm{CH}_{2} \mathrm{Cl}_{2}\right) \\
\text { (methylene chloride) }\end{array}$ & 32102 & $56-23-5$ & $\begin{array}{l}\text { Tetrachloromethane }\left(\mathrm{CCl}_{4}\right) \\
\text { (carbon tetrachloride) }\end{array}$ \\
\hline
\end{tabular}


Table 1. Volatile organic compounds analyzed during this study-Continued

[Compounds are identified by the following: PCODE, U.S. Geological Survey data base parameter code; CAS no., Chemical Abstract Services number; IUPAC, International Union of Pure and Applied Chemistry]

\begin{tabular}{|c|c|c|c|c|c|}
\hline PCODE & CAS no. & $\begin{array}{l}\text { IUPAC compound name } \\
\text { (chemical formula) (common name(s)) }\end{array}$ & PCODE & CAS no. & $\begin{array}{l}\text { IUPAC compound name } \\
\text { (chemical formula) (common name(s)) }\end{array}$ \\
\hline \multicolumn{6}{|c|}{ Target analytes-Continued } \\
\hline 32104 & $75-25-2$ & $\begin{array}{l}\text { Tribromomethane }\left(\mathrm{CHBr}_{3}\right) \\
\text { (bromoform) }\end{array}$ & 39180 & $79-01-6$ & $\begin{array}{l}\text { Trichloroethene }\left(\mathrm{C}_{2} \mathrm{HCl}_{3}\right) \\
\text { (trichloroethylene, } \mathrm{TCE})\end{array}$ \\
\hline 77652 & $76-13-1$ & $\begin{array}{l}\text { 1,1,2-Trichloro-1,2,2-trifluoroethane } \\
\qquad\left(\mathrm{C}_{2} \mathrm{Cl}_{3} \mathrm{~F}_{3}\right)(\mathrm{CFC} 113)\end{array}$ & 34488 & $75-69-4$ & $\begin{array}{l}\text { Trichlorofluoromethane }\left(\mathrm{CCl}_{3} \mathrm{~F}\right) \\
\quad(\mathrm{CFC} 11)\end{array}$ \\
\hline 77613 & $87-61-6$ & 1,2,3-Trichlorobenzene $\left(\mathrm{C}_{6} \mathrm{H}_{3} \mathrm{Cl}_{3}\right)$ & 32106 & $67-66-3$ & $\begin{array}{l}\text { Trichloromethane }\left(\mathrm{CHCl}_{3}\right) \\
\text { (chloroform) }\end{array}$ \\
\hline 34551 & $120-82-1$ & 1,2,4-Trichlorobenzene $\left(\mathrm{C}_{6} \mathrm{H}_{3} \mathrm{Cl}_{3}\right)$ & 77443 & $96-18-4$ & $\begin{array}{l}\text { 1,2,3-Trichloropropane }\left(\mathrm{C}_{3} \mathrm{H}_{5} \mathrm{Cl}_{3}\right) \\
\text { (allyl trichloride) }\end{array}$ \\
\hline 34506 & $71-55-6$ & $\begin{array}{l}\text { 1,1,1-Trichloroethane }\left(\mathrm{C}_{2} \mathrm{H}_{3} \mathrm{Cl}_{3} \text { ) }\right. \\
\text { (methyl chloroform) }\end{array}$ & 77222 & $95-63-6$ & $\begin{array}{l}\text { 1,2,4-Trimethylbenzene }\left(\mathrm{C}_{9} \mathrm{H}_{12}\right) \\
\text { (pseudocumene) }\end{array}$ \\
\hline 34511 & $79-00-5$ & $\begin{array}{l}\text { 1,1,2-Trichloroethane }\left(\mathrm{C}_{2} \mathrm{H}_{3} \mathrm{Cl}_{3}\right) \\
\text { (vinyl trichloride) }\end{array}$ & & & \\
\hline \multicolumn{6}{|c|}{ Other analytes } \\
\hline 81555 & $108-86-1$ & $\begin{array}{l}\text { Bromobenzene }\left(\mathrm{C}_{6} \mathrm{H}_{5} \mathrm{Br}\right) \\
\text { (phenyl bromide) }\end{array}$ & 77103 & $591-78-6$ & $\begin{array}{l}\text { 2-Hexanone }\left(\mathrm{C}_{6} \mathrm{H}_{12} \mathrm{O}\right) \\
\quad \text { (butyl methyl ketone, MBK) }\end{array}$ \\
\hline 77297 & $74-97-5$ & $\begin{array}{l}\text { Bromochloromethane }\left(\mathrm{CH}_{2} \mathrm{BrCl}\right) \\
\text { (methylene chlorobromide) }\end{array}$ & 77424 & $74-88-4$ & $\begin{array}{l}\text { Iodomethane }\left(\mathrm{CH}_{3} \mathrm{I}\right) \\
\text { (methyl iodide) }\end{array}$ \\
\hline 81595 & $78-93-3$ & $\begin{array}{l}\text { 2-Butanone }\left(\mathrm{C}_{4} \mathrm{H}_{8} \mathrm{O}\right) \\
\quad \text { (methyl ethyl ketone, MEK) }\end{array}$ & 77356 & $99-87-6$ & $\begin{array}{l}\text { 1-Isopropyl-4-methylbenzene }\left(\mathrm{C}_{10} \mathrm{H}_{14}\right) \\
\text { (p-isopropyltoluene) }\end{array}$ \\
\hline 77041 & $75-15-0$ & Carbon disulfide $\left(\mathrm{CS}_{2}\right)$ & 81597 & $80-62-6$ & $\begin{array}{l}\text { Methyl 2-methyl-2-propenoate }\left(\mathrm{C}_{5} \mathrm{H}_{8} \mathrm{O}_{2}\right) \\
\text { (methyl methacrylate) }\end{array}$ \\
\hline 77275 & $95-49-8$ & $\begin{array}{l}\text { 1-Chloro-2-methylbenzene }\left(\mathrm{C}_{7} \mathrm{H}_{7} \mathrm{Cl}\right) \\
\text { (o-chlorotoluene) }\end{array}$ & 78133 & $108-10-1$ & $\begin{array}{r}\text { 4-Methyl-2-pentanone }\left(\mathrm{C}_{6} \mathrm{H}_{12} \mathrm{O}\right) \\
\text { (isobutyl methyl ketone, MIK) }\end{array}$ \\
\hline 77277 & $106-43-4$ & $\begin{array}{l}\text { 1-Chloro-4-methylbenzene }\left(\mathrm{C}_{7} \mathrm{H}_{7} \mathrm{Cl}\right) \\
\text { (p-chlorotoluene) }\end{array}$ & 81593 & $126-98-7$ & $\begin{array}{l}\text { 2-Methyl-2-propenenitrile }\left(\mathrm{C}_{4} \mathrm{H}_{5} \mathrm{~N}\right) \\
\text { (methyl acrylonitrile) }\end{array}$ \\
\hline 78109 & $107-05-1$ & $\begin{array}{l}\text { 3-Chloro-1-propene }\left(\mathrm{C}_{3} \mathrm{H}_{5} \mathrm{Cl}\right) \\
\text { (allyl chloride) }\end{array}$ & 49991 & $96-33-3$ & $\begin{array}{l}\text { Methyl-2-propenoate }\left(\mathrm{C}_{4} \mathrm{H}_{6} \mathrm{O}_{2}\right) \\
\text { (methyl acrylate) }\end{array}$ \\
\hline 30217 & $74-95-3$ & $\begin{array}{l}\text { Dibromomethane }\left(\mathrm{CH}_{2} \mathrm{Br}_{2}\right) \\
\text { (methylene bromide) }\end{array}$ & 77350 & $135-98-8$ & $\begin{array}{l}\text { (1-Methylpropyl)benzene }\left(\mathrm{C}_{10} \mathrm{H}_{14}\right) \\
\text { (sec-butylbenzene) }\end{array}$ \\
\hline 73547 & $110-57-6$ & $\begin{array}{l}\text { trans-1,4-Dichloro-2-butene }\left(\mathrm{C}_{4} \mathrm{H}_{6} \mathrm{Cl}_{2}\right) \\
\quad((\mathrm{E})-1,4 \text {-dichloro-2-butene })\end{array}$ & 81576 & $60-29-7$ & $\begin{array}{l}\text { 1,1'-Oxybisethane }\left(\mathrm{C}_{4} \mathrm{H}_{10} \mathrm{O}\right) \\
\text { (diethyl ether) }\end{array}$ \\
\hline 77173 & $142-28-9$ & $\begin{array}{l}\text { 1,3-Dichloropropane }\left(\mathrm{C}_{3} \mathrm{H}_{6} \mathrm{Cl}_{2}\right) \\
\text { (trimethylene dichloride) }\end{array}$ & 81552 & $67-64-1$ & $\begin{array}{l}\text { 2-Propanone }\left(\mathrm{C}_{3} \mathrm{H}_{6} \mathrm{O}\right) \\
\text { (acetone) }\end{array}$ \\
\hline 77170 & $594-20-7$ & 2,2-Dichloropropane $\left(\mathrm{C}_{3} \mathrm{H}_{6} \mathrm{Cl}_{2}\right)$ & 77562 & $630-20-6$ & 1,1,1,2-Tetrachloroethane $\left(\mathrm{C}_{2} \mathrm{H}_{2} \mathrm{Cl}_{4}\right)$ \\
\hline 77168 & $563-58-6$ & 1,1-Dichloropropene $\left(\mathrm{C}_{3} \mathrm{H}_{4} \mathrm{Cl}_{2}\right)$ & 34516 & $79-34-5$ & 1,1,2,2-Tetrachloroethane $\left(\mathrm{C}_{2} \mathrm{H}_{2} \mathrm{Cl}_{4}\right)$ \\
\hline 77353 & $98-06-6$ & $\begin{array}{l}\text { (1,1-Dimethylethyl)benzene }\left(\mathrm{C}_{10} \mathrm{H}_{14}\right) \\
\text { (tert-butylbenzene) }\end{array}$ & 49999 & $488-23-3$ & $\begin{array}{l}\text { 1,2,3,4-Tetramethylbenzene }\left(\mathrm{C}_{10} \mathrm{H}_{14}\right) \\
\text { (prehitene) }\end{array}$ \\
\hline 81607 & $109-99-9$ & $\begin{array}{l}\text { 1,4-Epoxybutane }\left(\mathrm{C}_{4} \mathrm{H}_{8} \mathrm{O}\right) \\
\text { (tetrahydrofuran) }\end{array}$ & 50000 & $527-53-7$ & $\begin{array}{l}\text { 1,2,3,5-Tetramethylbenzene }\left(\mathrm{C}_{10} \mathrm{H}_{14}\right) \\
\text { (isodurene) }\end{array}$ \\
\hline 77220 & $611-14-3$ & $\begin{array}{l}\text { 1-Ethyl-2-methylbenzene }\left(\mathrm{C}_{9} \mathrm{H}_{12}\right) \\
\text { (2-ethyltoluene) }\end{array}$ & 77221 & $526-73-8$ & $\begin{array}{l}\text { 1,2,3-Trimethylbenzene }\left(\mathrm{C}_{9} \mathrm{H}_{12}\right) \\
\text { (hemimellitene) }\end{array}$ \\
\hline 73570 & $97-63-2$ & $\begin{array}{l}\text { Ethyl 2-methyl-2-propenoate }\left(\mathrm{C}_{6} \mathrm{H}_{10} \mathrm{O}_{2}\right) \\
\quad \text { (ethyl methacrylate) }\end{array}$ & 77226 & $108-67-8$ & $\begin{array}{l}\text { 1,3,5-Trimethylbenzene }\left(\mathrm{C}_{9} \mathrm{H}_{12}\right) \\
\text { (mesitylene) }\end{array}$ \\
\hline
\end{tabular}


The purpose of this report is twofold: (1) to document the study design used to evaluate the stability of low concentrations of VOCs in two different water matrices, and (2) to report the respective analytical results. A surface- and a ground-water matrix were spiked with 87 VOCs to achieve a theoretical concentration of $0.5 \mu \mathrm{g} / \mathrm{L}$ for most VOCs. Five replicate spike samples from each water matrix were analyzed at selected time intervals up to 216 days along with continuing calibration verification standards (CCVS). Continuing calibration verification standards are prepared daily from volatile-grade blank water spiked with all 87 VOCs included in this study at a concentration of approximately $1.0 \mu \mathrm{g} / \mathrm{L}$ for most VOCs.

\section{ACKNOWLEDGMENTS}

The authors wish to acknowledge those people that assisted in the development, design, and implementation of this VOC stability study. In particular, Brooke F. Connor from the USGS NWQL and Dr. James F. Pankow from the Department of Environmental Science and Engineering at Oregon Graduate Institute of Science and Technology, Beaverton, Oregon, are acknowledged. Dr. Herb Brass and his staff at the USEPA Office of Ground Water and Drinking Water, Cincinnati, Ohio, are also acknowledged for their technical input to this study.

\section{STUDY DESIGN}

The study used a design similar to that outlined in the American Society for Testing and Materials (1988), "Standard Practice for Estimation of Holding Time for Water Samples Containing Organic and Inorganic Constituents." The stability of VOCs in water is compound specific and may also depend on the water matrix. Data to characterize the stability of the 87 VOCs presented in table 1 were determined using replicate analyses at discrete time intervals. The water matrices examined included a surface-water sample collected from Bear Creek near Interstate Highway 470 in Morrison, Colorado, and a ground-water sample collected from a private well near Conifer, Colorado. The sample holding-time intervals used for this study were $0,14,28,37,47,56,112,156$, and 216 days. On day 0 , an unspiked sample from each water matrix was analyzed to measure VOC concentrations in the original matrix. Five replicate spike samples from each water matrix were subsequently analyzed on a random basis at each time interval.

The number of replicate spike samples was selected on the basis of laboratory precision data. A set of NWQL spiked sample data was used to characterize laboratory precision, which in turn, determined the number of replicate spike samples needed (American Society for Testing and Materials, 1988). The NWQL spiked samples were reagent water to which 87 VOCs were added to achieve a theoretical concentration of $0.5 \mu \mathrm{g} / \mathrm{L}$ for most of the VOCs. These samples are hereafter referred to as set spike samples. The replicate spike samples of each water matrix used to characterize the stability of VOCs in this study were also spiked with 87 VOCs to achieve a concentration of $0.5 \mu \mathrm{g} / \mathrm{L}$ for most of the VOCs.

\section{Determination of the Number of Replicate Spike Samples}

A set of concentration data from 60 set spike samples was obtained from the NWQL and used to document laboratory precision and to subsequently determine the number of replicate spike samples to be analyzed in the VOC stability study. The set spike samples were analyzed using multiple instruments and operators at the NWQL over a 6-month period. Summary statistics were calculated from this set of data, and the number of replicate spike samples to be analyzed in the VOC stability study were calculated using the following equation (American Society for Testing and Materials, 1988).

$$
N=\left(t \times R S D_{s s} / D\right)^{2},
$$

where

$N=$ minimum number of replicate spike samples required in the stability study;

$t=$ Student's $t$ (determined on the basis of set spike samples);

$R S D_{s s}=$ relative standard deviation of the set spike data, in percent; and

$D=20$ percent (maximum variation from mean concentration to be tolerated).

Table 2 lists the summary statistics for each VOC for the 60 set spike samples and the number of replicate spike samples required for each holding-time interval, as calculated using equation 1 . 
Table 2. Summary statistics for 60 spiked reagent-water samples (set spikes) used to calculate the number of replicate spike samples needed to determine volatile organic compound (VOC) stability at the 99-percent confidence interval

$\left[\mu \mathrm{g} / \mathrm{L}\right.$, micrograms per liter; $s$, standard deviation (in concentration terms) calculated from the set spike samples; $R S D_{s s}$, relative standard deviation of data from the set spike samples; \%, percent: $N$, number of replicate spike samples required for each holding-time interval]

\begin{tabular}{|c|c|c|c|c|c|}
\hline voc & $\begin{array}{c}\text { U.S. } \\
\text { Geological Survey } \\
\text { data base } \\
\text { parameter code }\end{array}$ & $\begin{array}{c}\text { Mean } \\
\text { concentration } \\
(\mu \mathrm{g} / \mathrm{L})\end{array}$ & $\begin{array}{c}s \\
\left(\mu g^{\prime} L\right)\end{array}$ & $\begin{array}{c}R S D_{s s} \\
(\%)\end{array}$ & $N$ \\
\hline \multicolumn{6}{|c|}{ Target analytes } \\
\hline Benzene & 34030 & 0.49 & 0.04 & 7.4 & 1 \\
\hline Bromodichloromethane & 32101 & .47 & .04 & 8.9 & 2 \\
\hline Bromoethene & 50002 & .46 & .04 & 9.5 & 2 \\
\hline Bromomethane & 34413 & .47 & .11 & 23.2 & 10 \\
\hline$n$-Butylbenzene & 77342 & .44 & .06 & 13.1 & 3 \\
\hline Chlorobenzene & 34301 & .48 & .03 & 5.8 & 1 \\
\hline Chloroethane & 34311 & .48 & .08 & 16.1 & 5 \\
\hline Chloroethene & 39175 & .55 & .13 & 23.3 & 10 \\
\hline Chloromethane & 34418 & .53 & .13 & 24.1 & 11 \\
\hline 1,2-Dibromo-3-chloropropane & 82625 & .43 & .13 & 29.0 & 15 \\
\hline Dibromochloromethane & 32105 & .46 & .04 & 8.8 & 2 \\
\hline 1,2-Dibromoethane & 77651 & .48 & .04 & 7.7 & 1 \\
\hline 1,2-Dichlorobenzene & 34536 & .48 & .07 & 14.9 & 4 \\
\hline 1,3-Dichlorobenzene & 34566 & .47 & .07 & 14.8 & 4 \\
\hline 1,4-Dichlorobenzene & 34571 & .46 & .07 & 15.5 & 5 \\
\hline Dichlorodifluoromethane & 34668 & .52 & .13 & 25.0 & 12 \\
\hline 1,1-Dichloroethane & 34496 & .50 & .04 & 8.8 & 2 \\
\hline 1,2-Dichloroethane & 32103 & .50 & .05 & 9.5 & 2 \\
\hline 1,1-Dichloroethene & 34501 & .49 & .08 & 15.4 & 5 \\
\hline cis-1,2-Dichloroethene & 77093 & .47 & .03 & 7.3 & 1 \\
\hline trans-1,2-Dichloroethene & 34546 & .48 & .03 & 7.1 & 1 \\
\hline Dichloromethane & 34423 & .54 & .07 & 13.0 & 3 \\
\hline 1,2-Dichloropropane & 34541 & .49 & .04 & 8.9 & 2 \\
\hline cis-1,3-Dichloropropene & 34704 & .44 & .04 & 9.4 & 2 \\
\hline trans-1,3-Dichloropropene & 34699 & .44 & .06 & 12.7 & 3 \\
\hline 1,2-Dimethylbenzene & 77135 & .48 & .03 & 7.2 & 1 \\
\hline 1,3- and 1,4-Dimethylbenzene & 85795 & .94 & .06 & 6.8 & 1 \\
\hline Ethenylbenzene & 77128 & .46 & .03 & 7.4 & 1 \\
\hline 2-Ethoxy-2-methylpropane & 50004 & .42 & .07 & 15.8 & 5 \\
\hline Ethylbenzene & 34371 & .47 & .03 & 6.8 & 1 \\
\hline
\end{tabular}


Table 2. Summary statistics for 60 spiked reagent-water samples (set spikes) used to calculate the number of replicate spike samples needed to determine volatile organic compound (VOC) stability at the 99-percent confidence interval-Continued

$\left[\mu \mathrm{g} / \mathrm{L}\right.$, micrograms per liter; $s$, standard deviation (in concentration terms) calculated from the set spike samples; $R S D_{s s}$, relative standard deviation of data from the set spike samples; \%, percent; $N$, number of replicate spike samples required for each holding-time interval]

\begin{tabular}{|c|c|c|c|c|c|}
\hline voc & $\begin{array}{c}\text { U.S. } \\
\text { Geological Survey } \\
\text { data base } \\
\text { parameter code }\end{array}$ & $\begin{array}{c}\text { Mean } \\
\text { concentration } \\
(\mu g / L)\end{array}$ & $\begin{array}{c}s \\
(\mu g / L)\end{array}$ & $\begin{array}{c}R S D_{s S} \\
(\%)\end{array}$ & $N$ \\
\hline \multicolumn{6}{|c|}{ Target analytes-Continued } \\
\hline 1,1,2,3,4,4-Hexachloro-1,3-butadiene & 39702 & 0.47 & 0.07 & 14.5 & 4 \\
\hline 1,1,1,2,2,2-Hexachloroethane & 34396 & .48 & .07 & 15.3 & 5 \\
\hline 2-Methoxy-2-methybutane & 50005 & .41 & .05 & 11.0 & 3 \\
\hline 2-Methoxy-2-methylpropane & 78032 & .44 & .05 & 11.3 & 3 \\
\hline Methylbenzene & 34010 & .49 & .03 & 5.9 & 1 \\
\hline (1-Methylethyl)benzene & 77223 & .49 & .04 & 7.2 & 1 \\
\hline Naphthalene & 34696 & .48 & .08 & 17.2 & 6 \\
\hline 2,2'-Oxybis[propane] & 81577 & .40 & .06 & 14.7 & 4 \\
\hline 2-Propenal & 34210 & 19.0 & 3.0 & 15.5 & 5 \\
\hline 2-Propenenitrile & 34215 & 9.9 & 1.2 & 12.4 & 3 \\
\hline n-Propylbenzene & 77224 & .47 & .03 & 6.4 & 1 \\
\hline Tetrachloroethene & 34475 & .48 & .06 & 13.4 & 4 \\
\hline Tetrachloromethane & 32102 & .48 & .04 & 8.2 & 2 \\
\hline Tribromomethane & 32104 & .46 & .05 & 11.6 & 3 \\
\hline 1,1,2-Trichloro-1,2,2-trifluoroethane & 77652 & .46 & .07 & 14.8 & 4 \\
\hline 1,2,3-Trichlorobenzene & 77613 & .46 & .08 & 16.5 & 5 \\
\hline 1,2,4-Trichlorobenzene & 34551 & .44 & .07 & 16.6 & 5 \\
\hline 1,1,1-Trichloroethane & 34506 & .49 & .03 & 6.1 & 1 \\
\hline 1,1,2-Trichloroethane & 34511 & .49 & .04 & 8.6 & 2 \\
\hline Trichloroethene & 39180 & .47 & .03 & 5.9 & 1 \\
\hline Trichlorofluoromethane & 34488 & .47 & .07 & 14.3 & 4 \\
\hline Trichloromethane & 32106 & .51 & .06 & 12.4 & 3 \\
\hline 1,2,3-Trichloropropane & 77443 & .47 & .05 & 11.1 & 3 \\
\hline 1,2,4-Trimethylbenzene & 77222 & .46 & .04 & 9.4 & 2 \\
\hline \multicolumn{6}{|c|}{ Other analytes } \\
\hline Bromobenzene & 81555 & .46 & .07 & 15.0 & 4 \\
\hline Bromochloromethane & 77297 & .50 & .03 & 5.2 & 1 \\
\hline 2-Butanone & 81595 & 5.1 & .57 & 11.2 & 3 \\
\hline Carbon disulfide & 77041 & .52 & .12 & 22.2 & 9 \\
\hline 1-Chloro-2-methylbenzene & 77275 & .46 & .07 & 14.4 & 4 \\
\hline
\end{tabular}


Table 2. Summary statistics for 60 spiked reagent-water samples (set spikes) used to calculate the number of replicate spike samples needed to determine volatile organic compound (VOC) stability at the 99-percent confidence interval-Continued

[ $\mu \mathrm{g} / \mathrm{L}$, micrograms per liter; $s$, standard deviation (in concentration terms) calculated from the set spike samples; $R S D_{s s,}$, relative standard deviation of data from the set spike samples; $\%$, percent; $N$, number of replicate spike samples required for each holding-time interval]

\begin{tabular}{|c|c|c|c|c|c|}
\hline voc & $\begin{array}{c}\text { U.S. } \\
\text { Geological Survey } \\
\text { data base } \\
\text { parameter code }\end{array}$ & $\begin{array}{c}\text { Mean } \\
\text { concentration } \\
(\mu \mathrm{g} / \mathrm{L})\end{array}$ & $\begin{array}{c}s \\
(\mu g / L)\end{array}$ & $\begin{array}{c}R S D_{s s} \\
(\%)\end{array}$ & $N$ \\
\hline \multicolumn{6}{|c|}{ Other analytes - Continued } \\
\hline 1-Chloro-4-methylbenzene & 77277 & 0.48 & 0.03 & 7.2 & 1 \\
\hline 3-Chloro-1-propene & 78109 & .86 & .07 & 8.5 & 2 \\
\hline Dibromomethane & 30217 & .49 & .04 & 7.9 & 2 \\
\hline trans-1,4-Dichloro-2-butene & 73547 & 4.3 & .69 & 16.1 & 5 \\
\hline 1,3-Dichloropropane & 77173 & .47 & .04 & 9.1 & 2 \\
\hline 2,2-Dichloropropane & 77170 & .49 & .04 & 7.3 & 1 \\
\hline 1,1-Dichloropropene & 77168 & .48 & .03 & 6.7 & 1 \\
\hline (1,1-Dimethylethyl)benzene & 77353 & .46 & .04 & 9.2 & 2 \\
\hline 1,4-Epoxybutane & 81607 & 4.5 & .53 & 11.8 & 3 \\
\hline 1-Ethyl-2-methylbenzene & 77220 & .38 & .03 & 8.1 & 2 \\
\hline Ethyl 2-methyl-2-propenoate & 73570 & 2.27 & .17 & 7.4 & 1 \\
\hline 2-Hexanone & 77103 & 4.8 & .61 & 12.8 & 3 \\
\hline Iodomethane & 77424 & .47 & .11 & 22.7 & 10 \\
\hline 1-Isopropyl-4-methylbenzene & 77356 & .44 & .07 & 16.4 & 5 \\
\hline Methyl 2-methyl-2-propenoate & 81597 & 2.6 & .25 & 9.9 & 2 \\
\hline 4-Methyl-2-pentanone & 78133 & 4.8 & .54 & 11.4 & 3 \\
\hline 2-Methyl-2-propenenitrile & 81593 & 2.4 & .22 & 9.1 & 2 \\
\hline Methyl-2-propenoate & 49991 & 2.3 & .22 & 9.8 & 2 \\
\hline (1-Methylpropyl)benzene & 77350 & .46 & .05 & 10.3 & 2 \\
\hline 1,1'-Oxybisethane & 81576 & .94 & .16 & 17.3 & 6 \\
\hline 2-Propanone & 81552 & 5.6 & 1.6 & 27.9 & 14 \\
\hline 1,1,1,2-Tetrachloroethane & 77562 & .48 & .07 & 15.2 & 5 \\
\hline 1,1,2,2-Tetrachloroethane & 34516 & .47 & .08 & 16.0 & 5 \\
\hline 1,2,3,4-Tetramethylbenzene & 49999 & .44 & .07 & 16.3 & 5 \\
\hline 1,2,3,5-Tetramethylbenzene & 50000 & .38 & .04 & 10.8 & 3 \\
\hline 1,2,3-Trimethylbenzene & 77221 & .35 & .04 & 10.6 & 2 \\
\hline 1,3,5-Trimethylbenzene & 77226 & .46 & .03 & 7.5 & 1 \\
\hline Vinyl acetate & 77057 & 4.4 & .65 & 14.9 & 4 \\
\hline
\end{tabular}


The value of 20 percent was chosen as the maximum variation from the mean concentration to avoid the need to analyze an unrealistic number of replicate spike samples and 20 percent reflects a maximum variation of $0.1 \mu \mathrm{g} / \mathrm{L}$ for most VOCs. The value of the Student's $t$ statistic for a two-tailed 99-percent confidence interval determined on the basis of the 60 set spike samples analyzed by the NWQL is 2.660 (Dougherty, 1990). Note that the number of required replicate spike samples was rounded up to the nearest whole number (table 2 ). The number of replicate spike samples $(N)$ required to determine VOC sample stability ranged from 1 to 15 . Analysis of 15 replicate spike samples at each selected time interval was unrealistic and cost prohibitive for the stability study. Thus, the number of replicate spike samples required for this study was selected such that it was sufficient for most VOCs listed in table 1. Table 3 lists the percentage of VOCs that satisfy the conditions of equation 1 for various assumed numbers of replicate spike samples. Five replicate spike samples were selected for this study because approximately 89 percent ( 77 of 87 VOCs) of the VOCs listed in table 1 satisfied the conditions of equation 1 to evaluate sample stability (table 3). The VOCs that did not satisfy the conditions of equation 1 using five replicate spike samples include: bromomethane, carbon disulfide, chloroethene, chloromethane, 1,2-dibromo-3-chloropropane, dichlorodifluoromethane, iodomethane, naphthalene, 1,1'-oxybisethane, and 2-propanone. Some of the 10 VOCs that did not satisfy the conditions of equation 1 are possible laboratory contaminants that randomly appear in the reagent water used for the 60 set spike samples or are known contaminants in the $\mathrm{HCl}$ used to preserve the replicate spike samples.

\section{Study Methods}

Maskarinec and others (1990) reported that the analytical precision and aliquot-to-aliquot variability were less than 5 percent when preparing samples from stock VOC solution held in a Tedlar sampling bag. No VOC loss from the Tedlar sampling bag was indicated over a 24-hour period. Thus, Tedlar sampling bags were used in this VOC stability study to transfer the spiked water matrices preserved with $\mathrm{HCl}$ to volatile organic analysis vials. Two sampling bags were used-one for each water matrix. Three liters of surface water were added to one sampling bag and $3 \mathrm{~L}$ of ground water were added to the second sampling bag.
Table 3. Number and percentage of volatile organic compounds (VOCs) that satisfy the conditions of equation 1 for assumed numbers of replicate spike samples

\begin{tabular}{ccc}
\hline $\begin{array}{c}\text { Assumed number } \\
\text { of replicate } \\
\text { spike samples }\end{array}$ & $\begin{array}{c}\text { Number of Vocs } \\
\text { included }\end{array}$ & $\begin{array}{c}\text { Percentage of } \\
\text { Vocs included }\end{array}$ \\
\hline 3 & 54 & 62 \\
4 & 64 & 74 \\
5 & 77 & 89 \\
6 & 79 & 91 \\
7 & 79 & 91 \\
8 & 79 & 91 \\
9 & 80 & 92 \\
10 & 83 & 95 \\
\hline
\end{tabular}

Each bag was stored in a dedicated refrigerator for 2 days to allow for any degassing that might occur. Headspace acquired after 2 days was removed from each sampling bag and $\mathrm{HCl}$ was added to each bag to achieve a pH of 2.0. Stock solution containing the VOCs listed in table 1 was added to each sampling bag to achieve a theoretical concentration of $0.5 \mu \mathrm{g} / \mathrm{L}$ for most of the 87 VOCs. Teflon tubing was attached to the on/off valve on each bag. Fifty volatile organic analysis vials were filled randomly from each sampling bag by filling each vial from the bottom up.

Ten samples known to be VOC free were prepared prior to any spiking procedures and placed in the same refrigerator that all other samples for this study were stored. The VOC-free samples contained water that was boiled, purged with nitrogen, and preserved with two drops of 1:1 HCl to achieve a pH less than 2.0. These samples are referred to as refrigerator blanks. The refrigerator was purchased new, and no additional samples of any type were kept in it during the period of this study.

Five spiked time-zero $\left(\mathrm{t}_{0}\right)$ samples for each water matrix were analyzed immediately. All samples for this study were analyzed using purge and trap gas chromatography/mass spectrometry ( $\mathrm{P}+\mathrm{T}$ GC/MS). $\mathrm{P}+\mathrm{T}$ GC/MS provides both very reliable identification and quantification for VOCs. The remaining samples were stored in a refrigerator at $4^{\circ} \mathrm{C}$ until they were ready to be analyzed. All five replicate spike samples for each water matrix were analyzed on the same days as part of 
the normal NWQL analysis routine for VOCs (Connor and others, 1998).

\section{ANALYTICAL RESULTS}

Analytical results for the surface- and groundwater matrices are presented in Section A (table 4) of the Supplemental Information section at the end of this report. Table 4 includes replicate-sample data for each spiked-water matrix, for all 87 VOCs included in this study. Five replicate spike samples of each water matrix were analyzed along with one refrigerator blank sample on days $0,14,28,37,47,56,112,156$, and 216 . On day 0 , an unspiked sample from each water matrix was analyzed to measure VOC concentrations in the original matrix. Concentration data are presented graphically in Section B from day 0 through day 216. The surface- and ground-water matrices appear together for comparison purposes.

Analytical results for CCVS are presented graphically in Section B and tabularly in Section C (table 5). Three replicate CCVS were analyzed on days $0,14,28,37,47,56,112,156$, and 216 to confirm that calibration was consistent (Connor and others, 1998). The CCVS percent-recovery data are provided to help determine if trends in VOC concentrations in the surface- and ground-water matrices are due to instrument variation over time or due to chemical instability.

\section{REFERENCES CITED}

American Society for Testing and Materials, 1988, Standard practice for estimation of holding time for water samples containing organic and inorganic constituents: Scranton, Penn., 5 p. Designation D 4841-88.

Connor, B.F., Rose, D.L., Noriega, M.C., Murtagh, L.K., and Abney, S.R., 1998, Methods of analysis by the U.S. Geological Survey National Water-Quality Laboratory-determination of 86 volatile organic compounds in water by gas chromatography/mass spectrometry, including detections less than reporting limits: U.S. Geological Survey Open-File Report 97-829, 78 p.

Dougherty, E.R., 1990, Probability and statistics for the engineering, computing, and physical sciences: Englewood Cliffs, New Jersey, Prentice-Hall, Inc., 734 p.

Eichelberger, J.W., and Budde, W.L., 1989, Method 524.2. Measurement of purgeable organic compounds in water by capillary column gas chromatography/mass spectrometry, Revision 4.0: Cincinnati, Ohio, Environmental Monitoring Systems Laboratory, Office of Research and Development, p. 283-320.

Máskarinec, M.P., Johnson, L.H., Holladay, S.K., Moody, R.L., Bayne, C.K., and Jenkins, R.A., 1990, Stability of volatile organic compounds in environmental water samples during transport and storage: Environmental Science and Technology, v. 24, no. 11, p. 1665-1670.

Munch, J.W., 1995, Method 524.2 - Measurement of purgeable organic compounds in water by capillary column gas chromatography/mass spectrometry, Revision 4.1: Cincinnati, Ohio, Environmental Monitoring Systems Laboratory, U.S. Environmental Protection Agency, 48 p. 
SUPPLEMENTAL INFORMATION 


\section{Section A - Analytical Results for Surface- and Ground-Water Matrices}




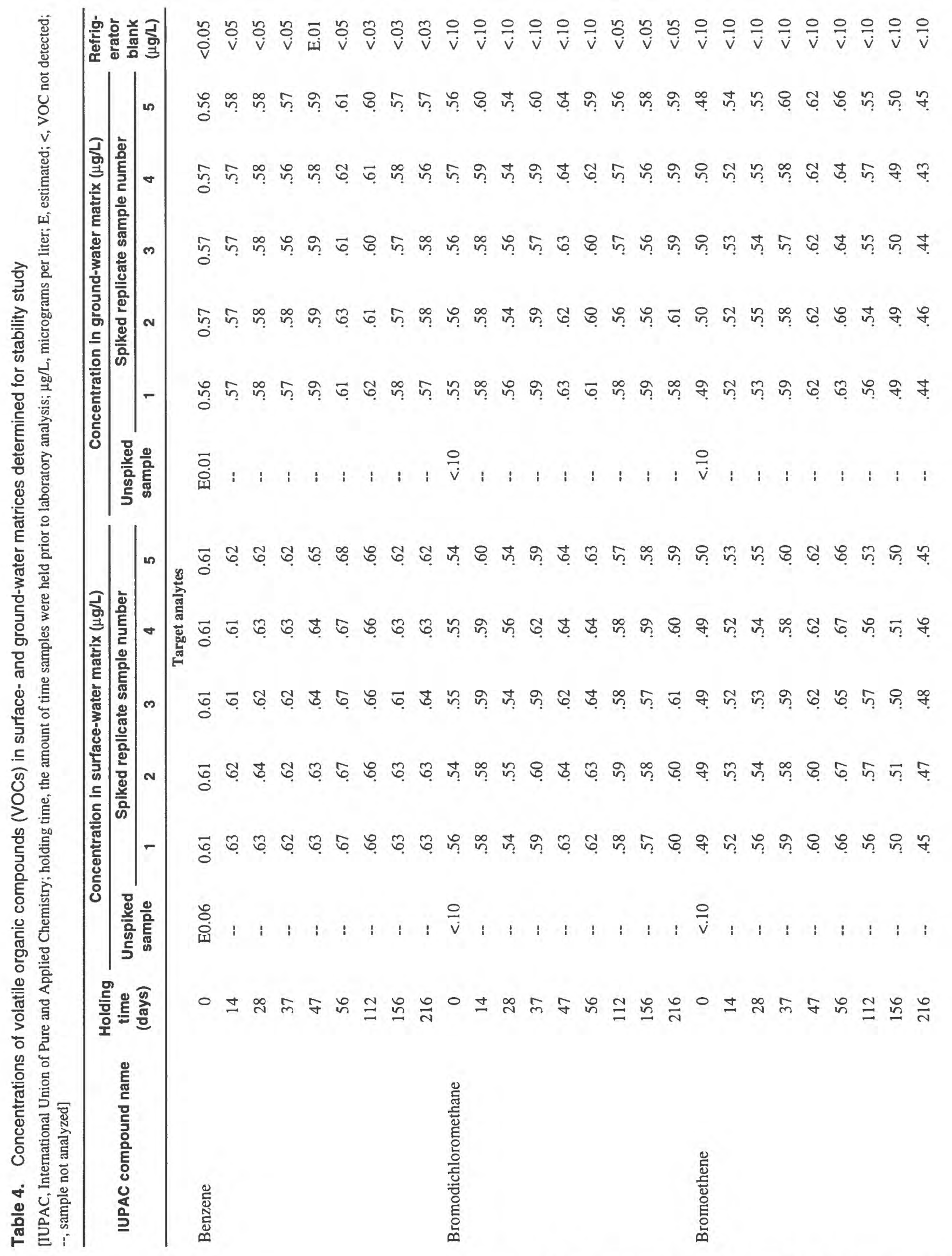




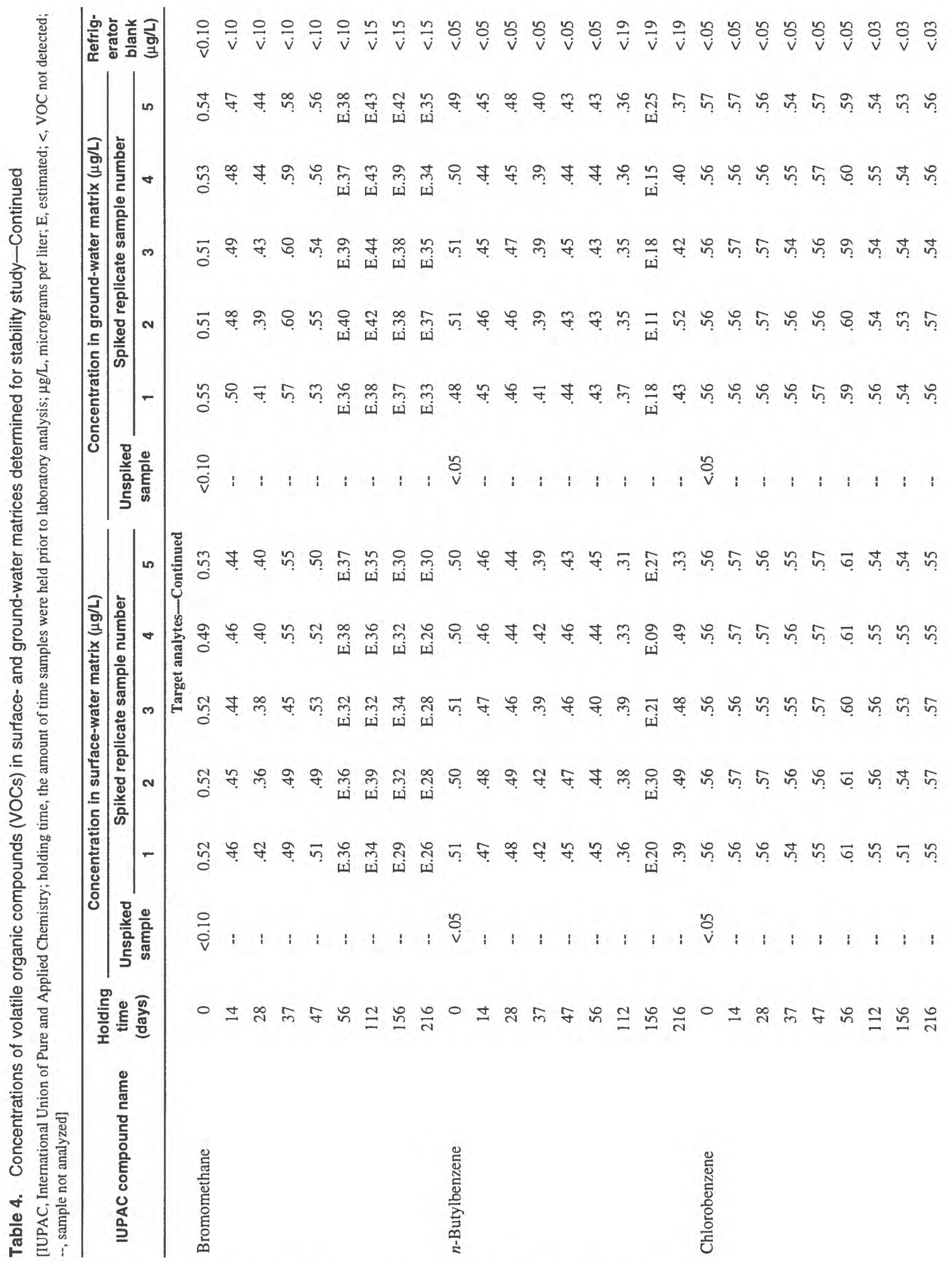




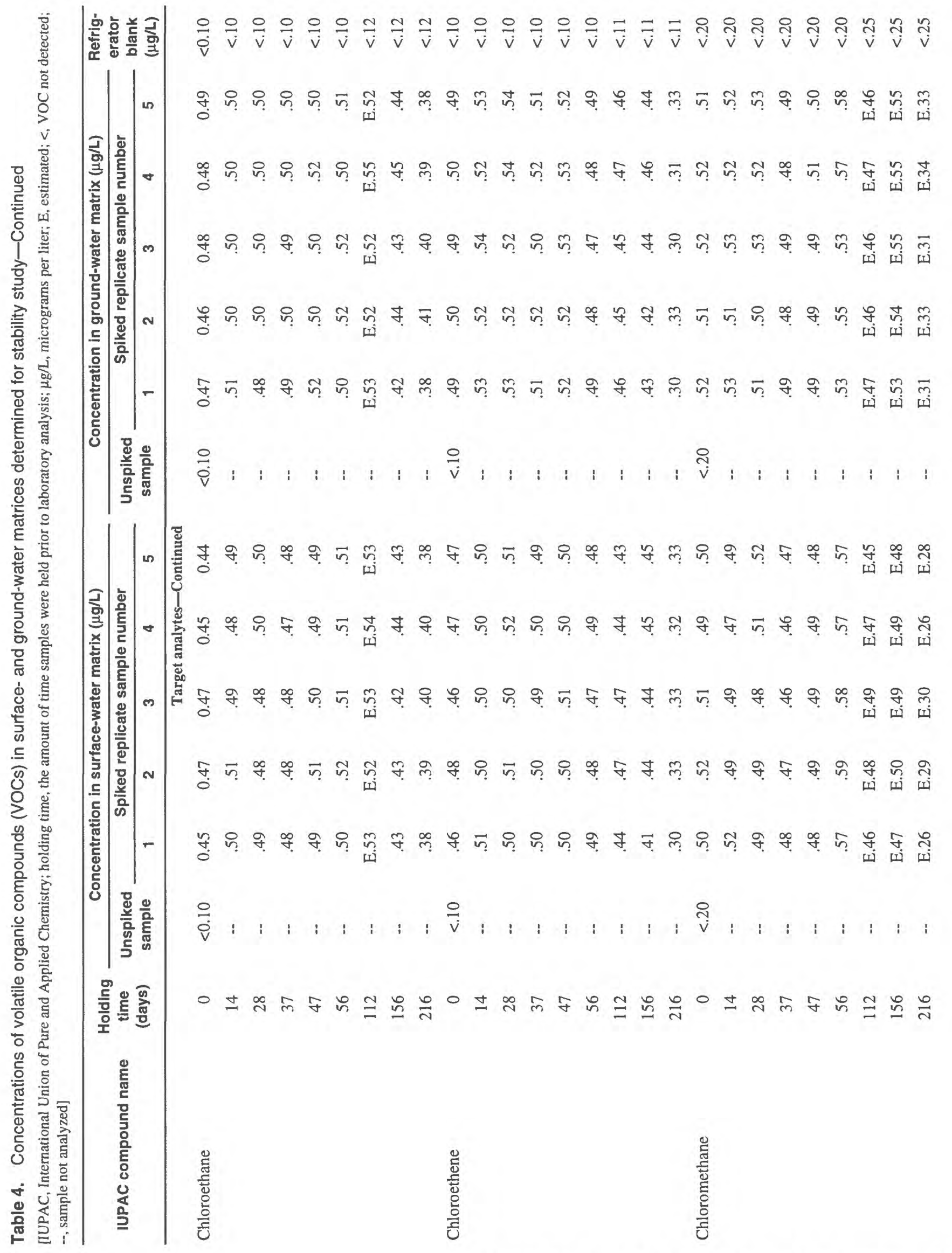




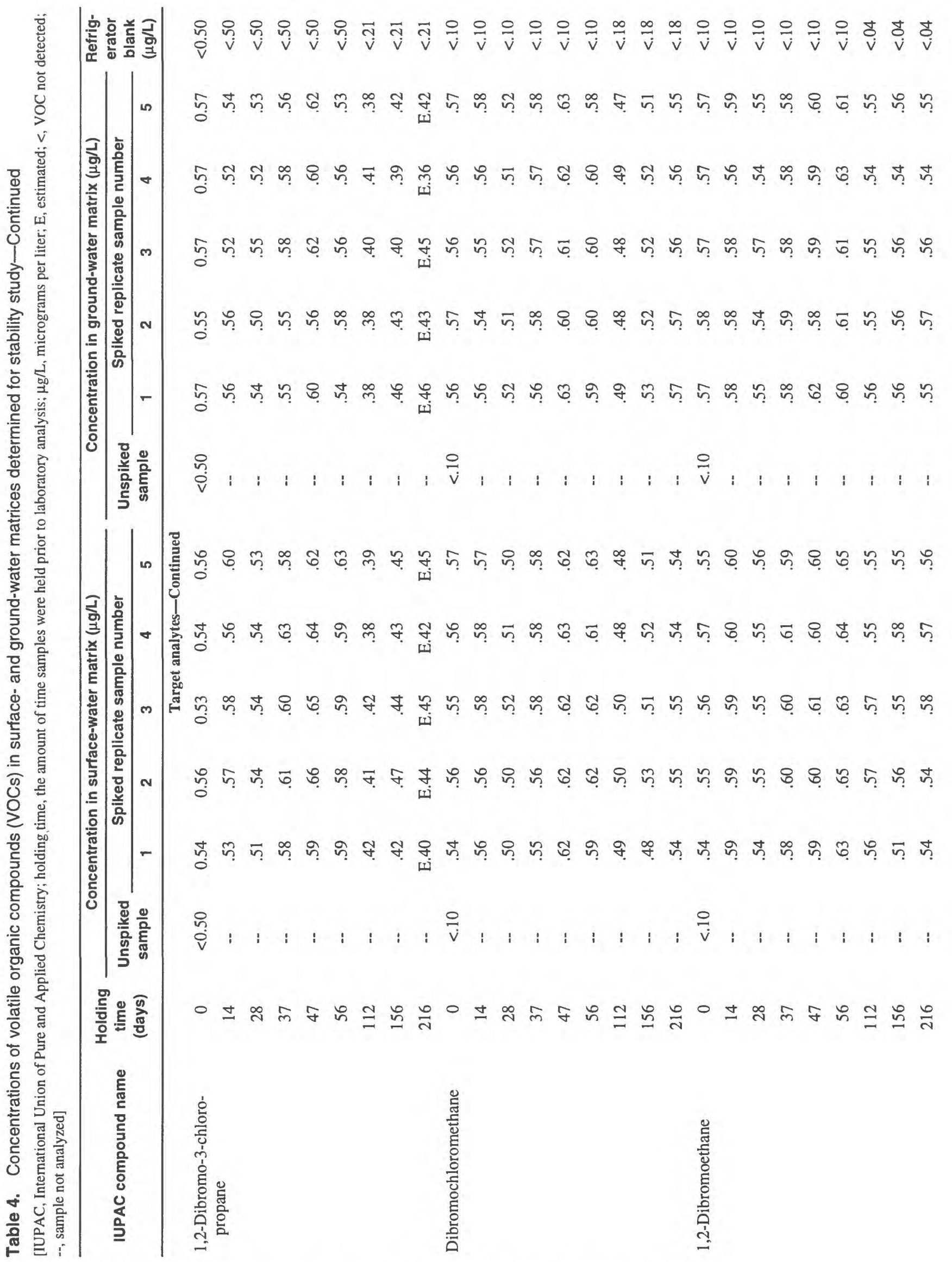




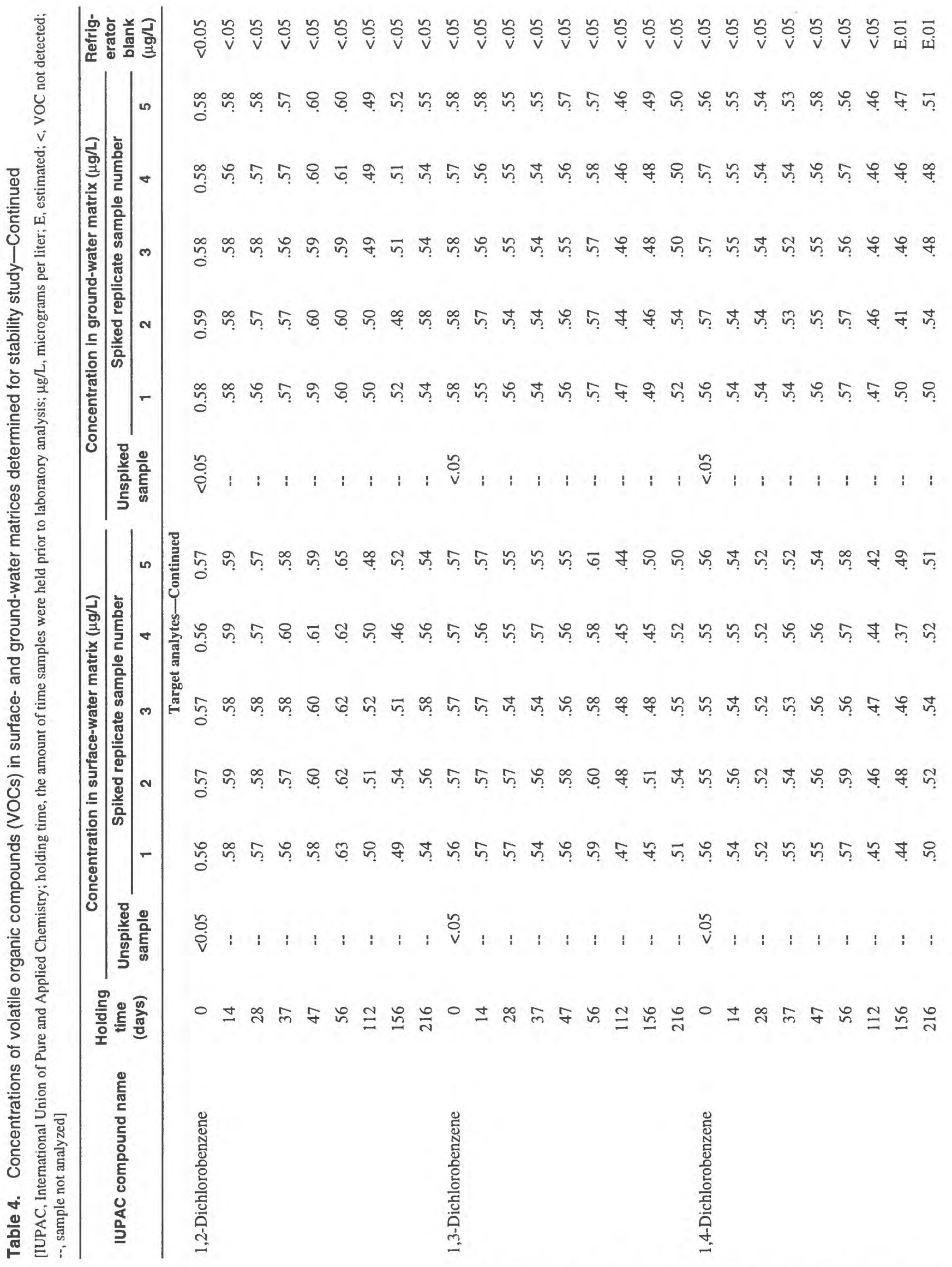




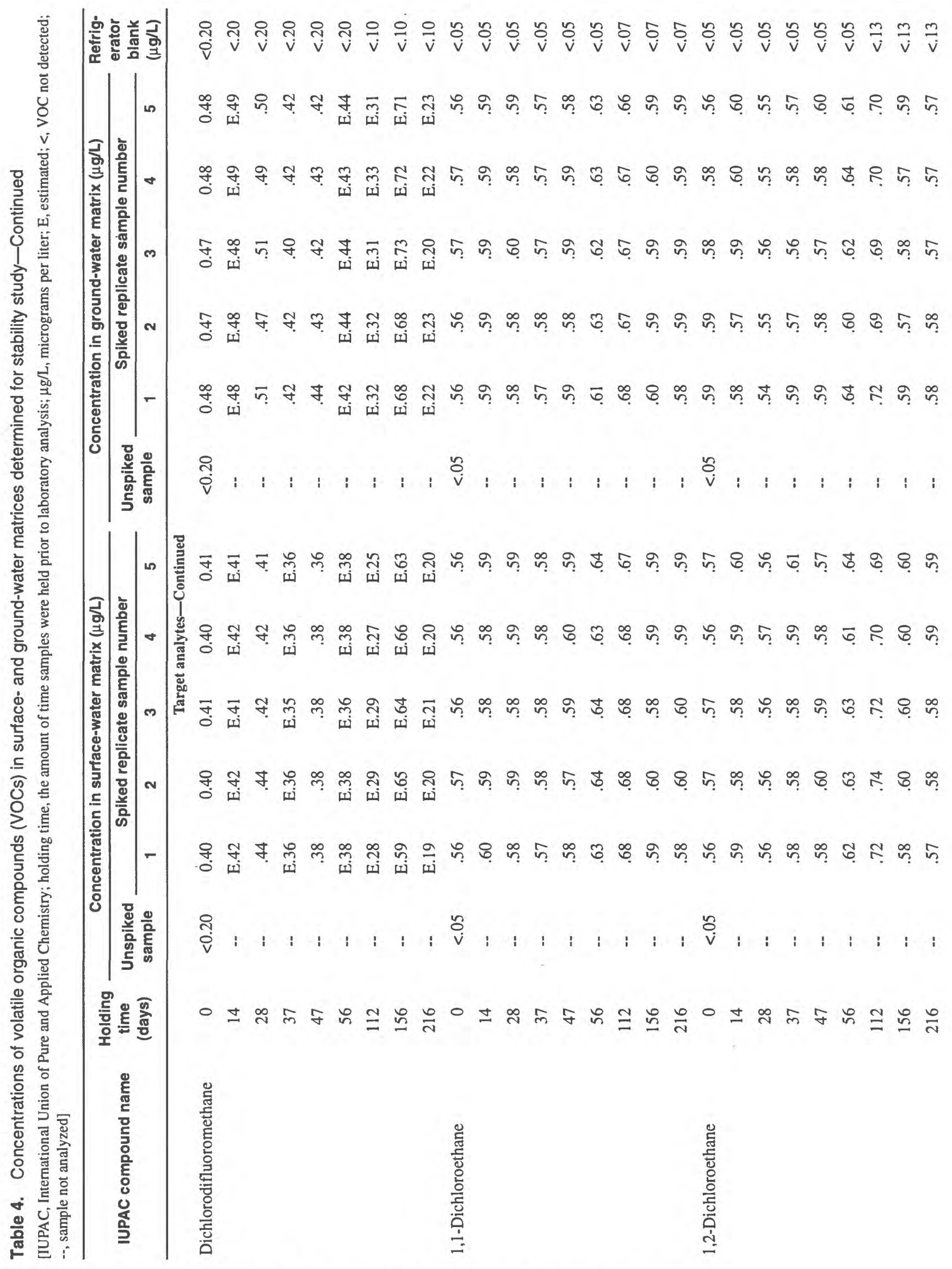




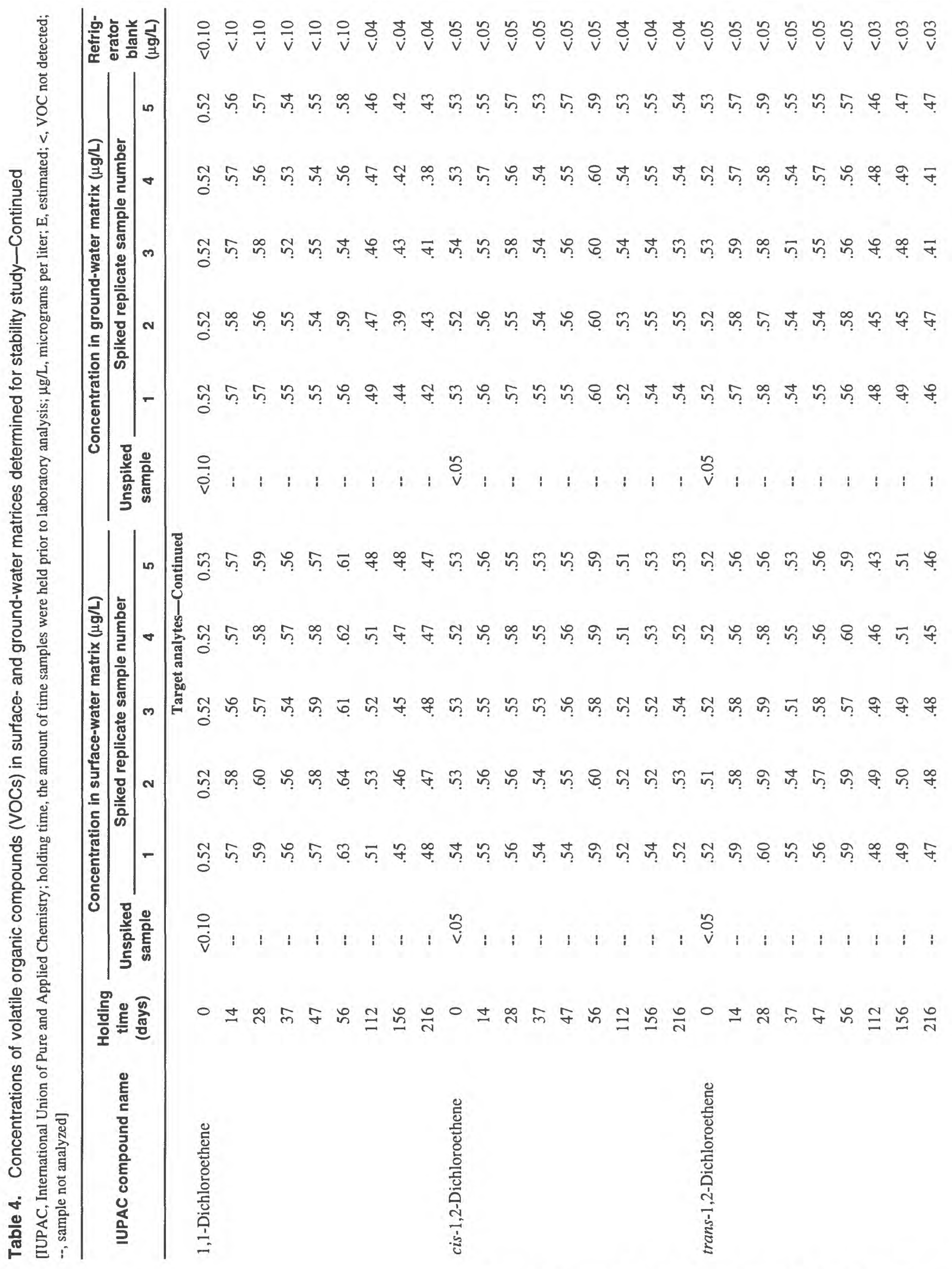




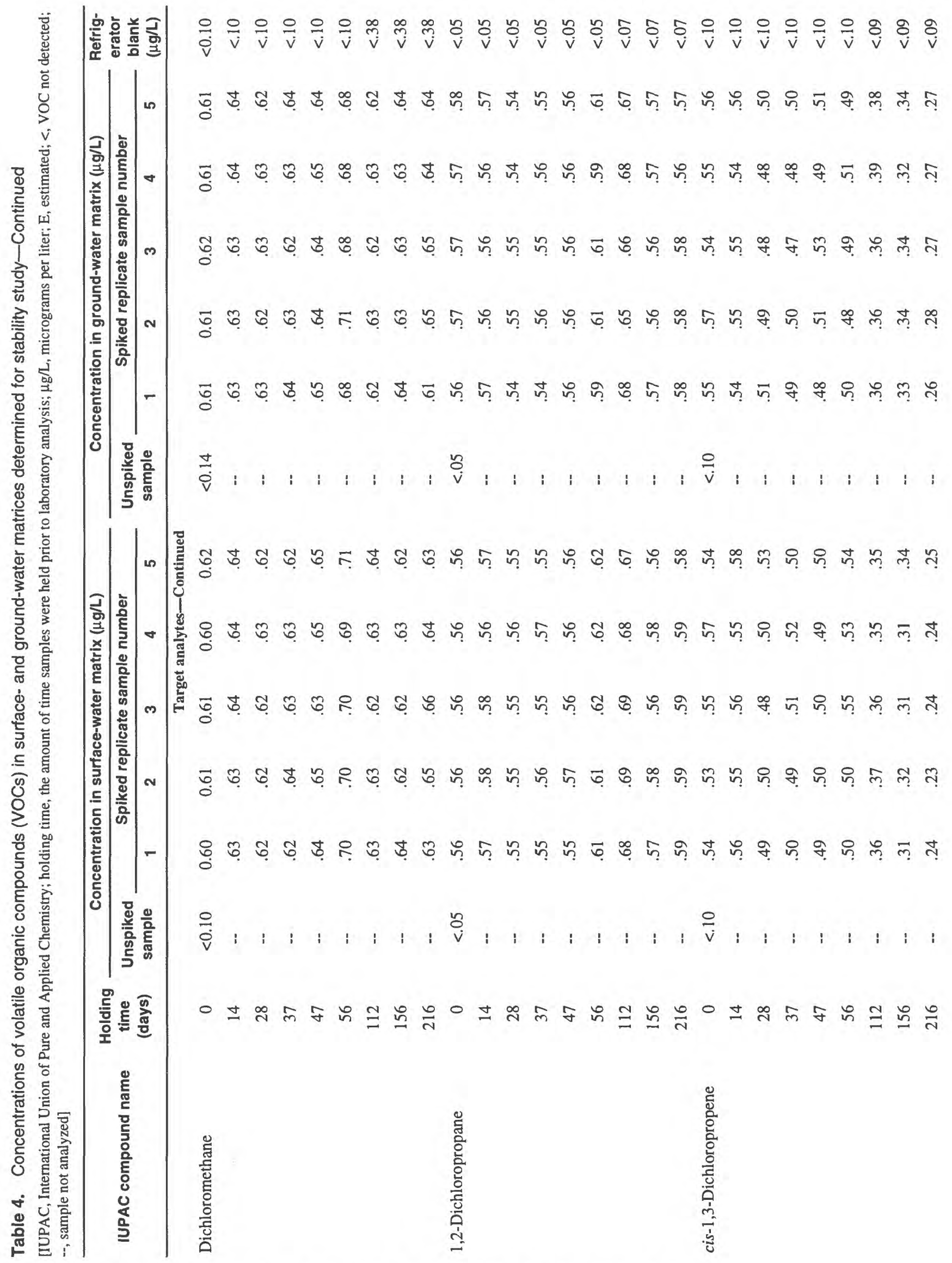




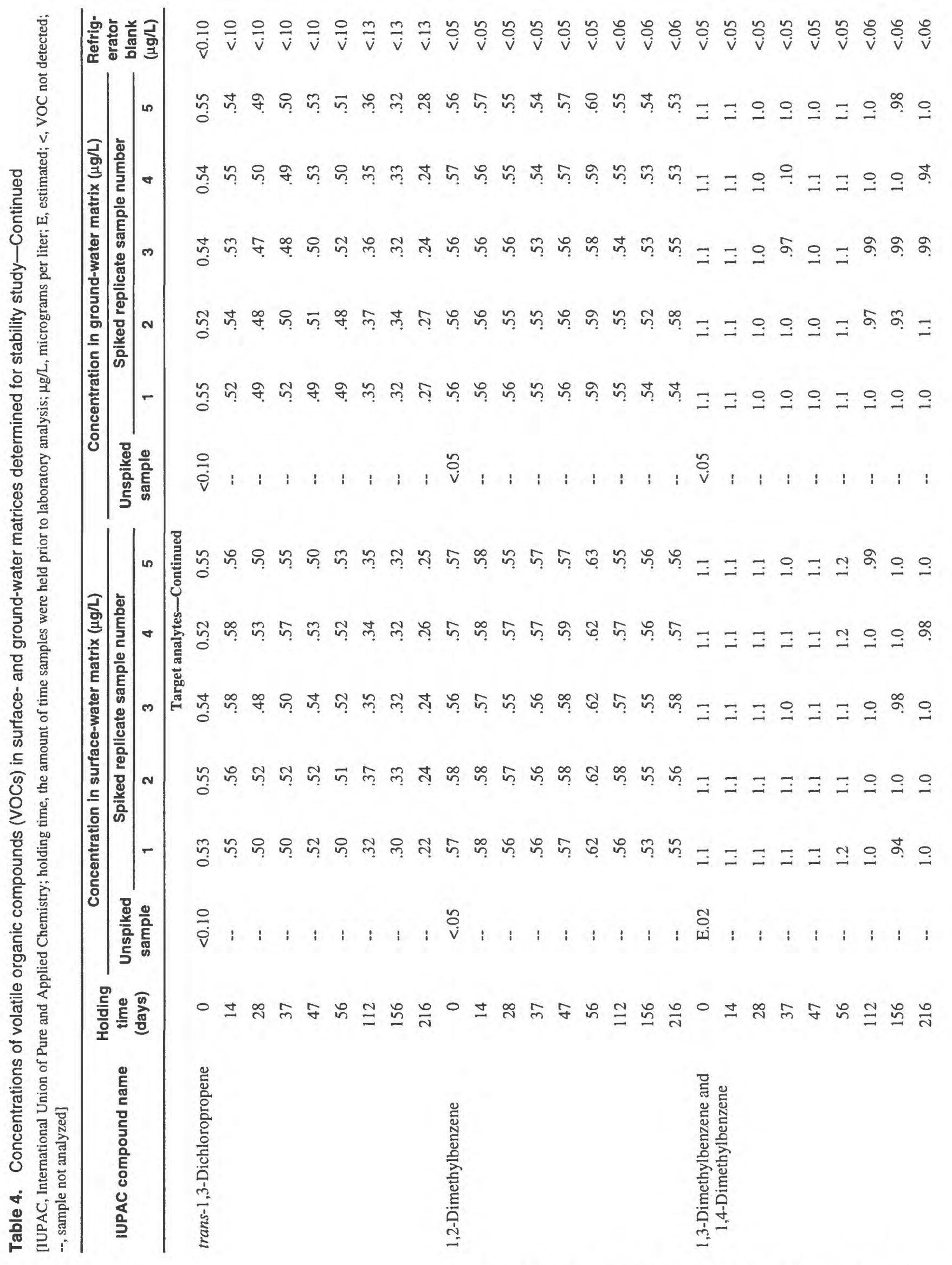




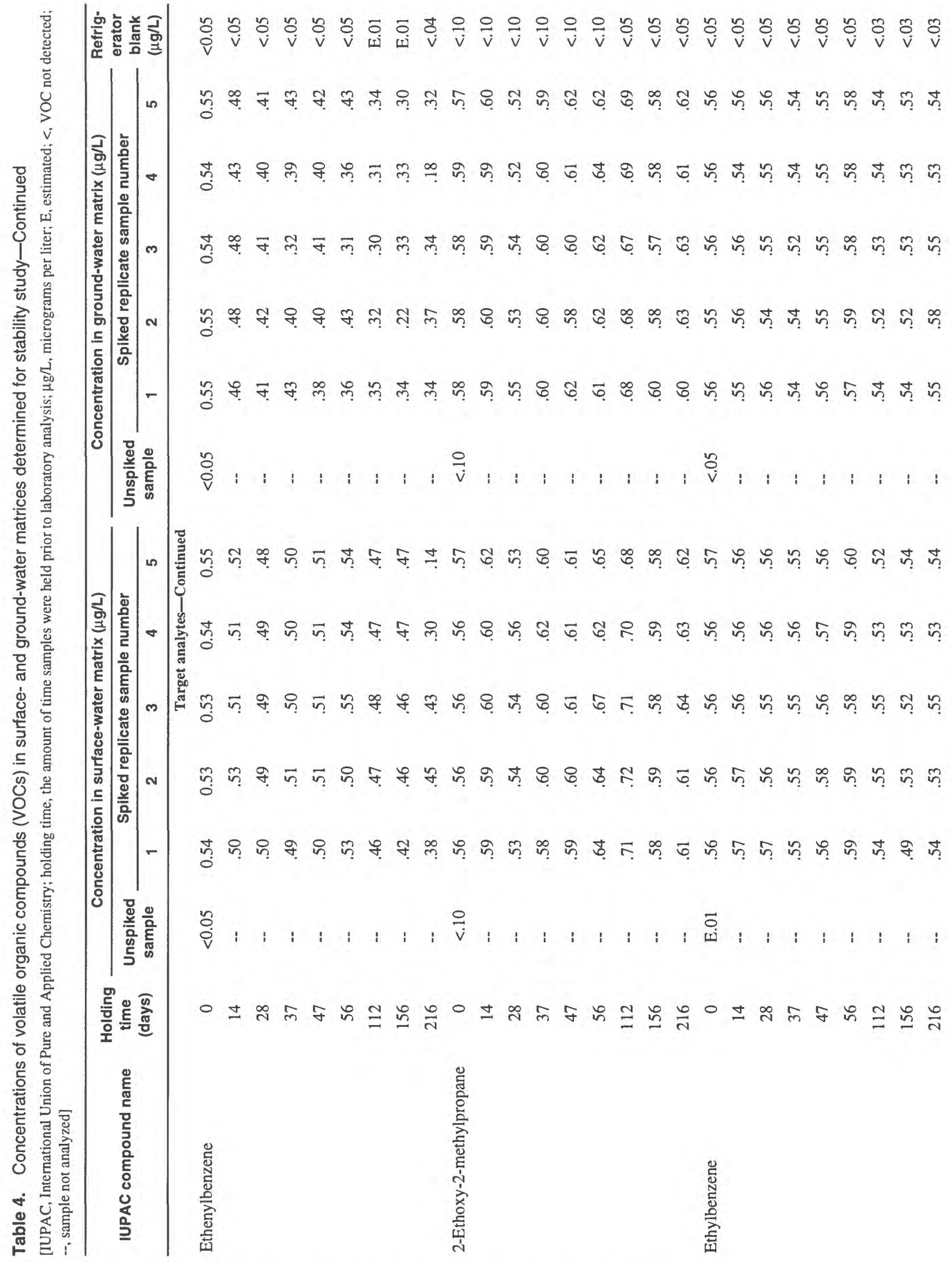




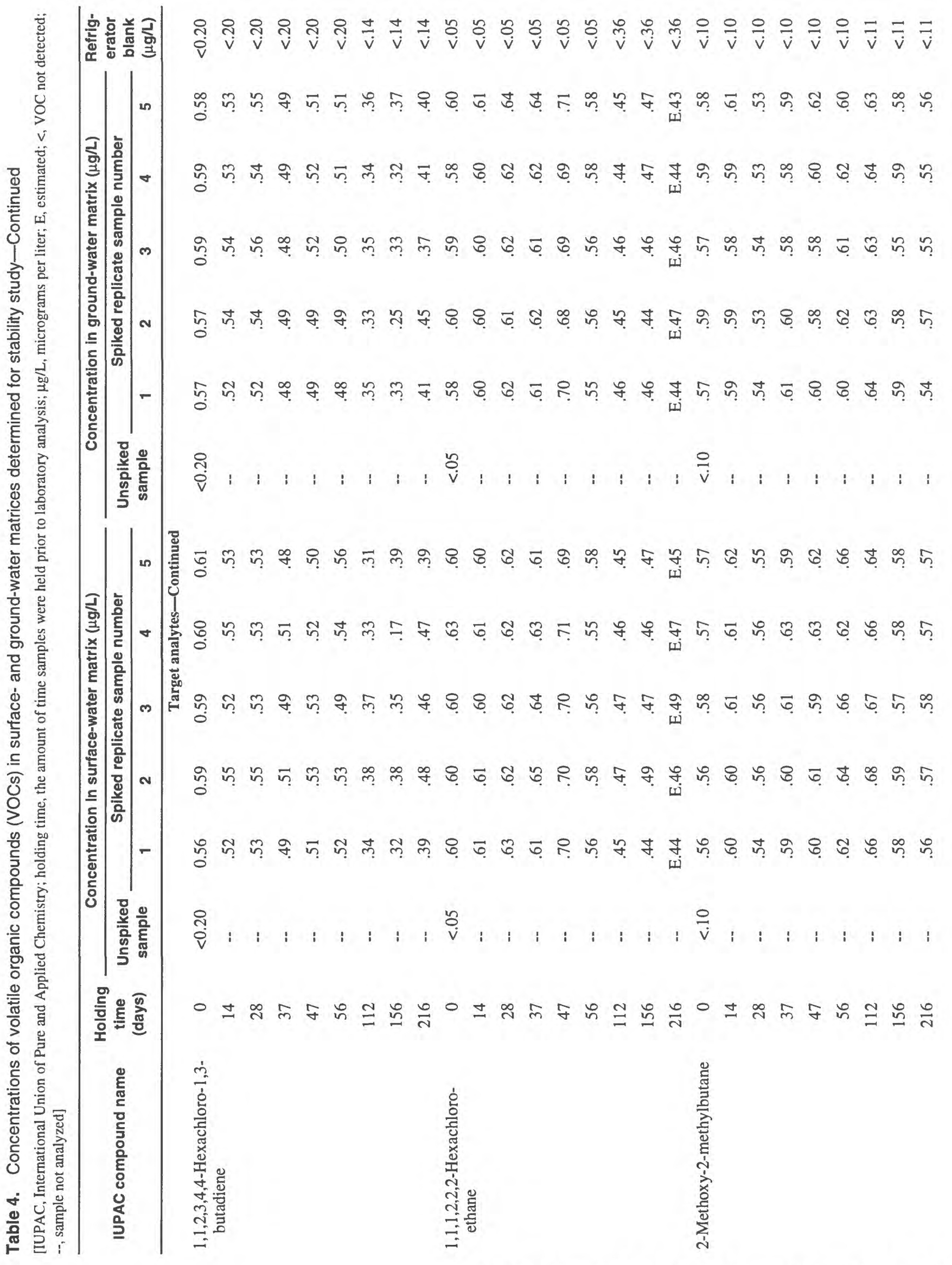




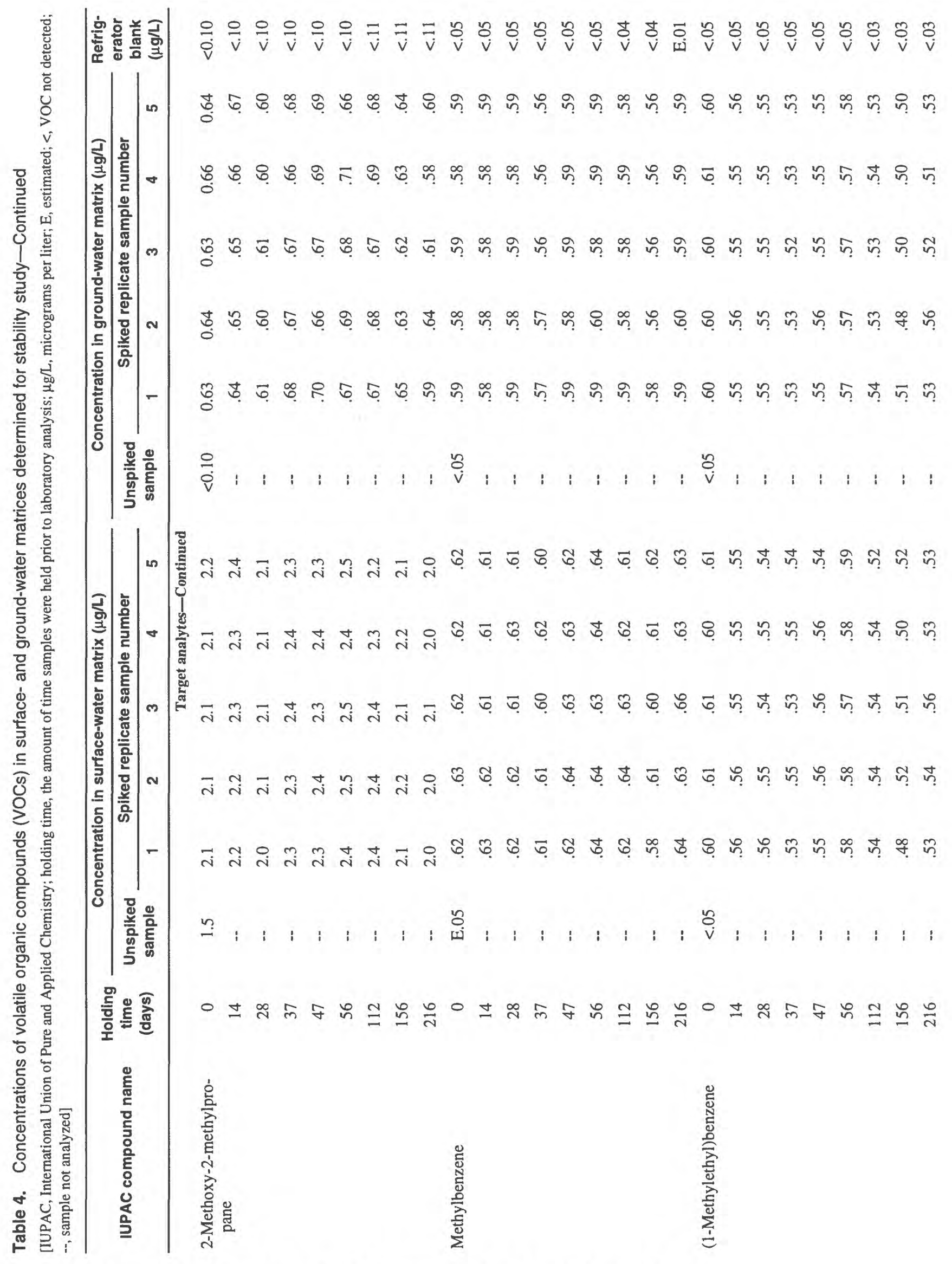




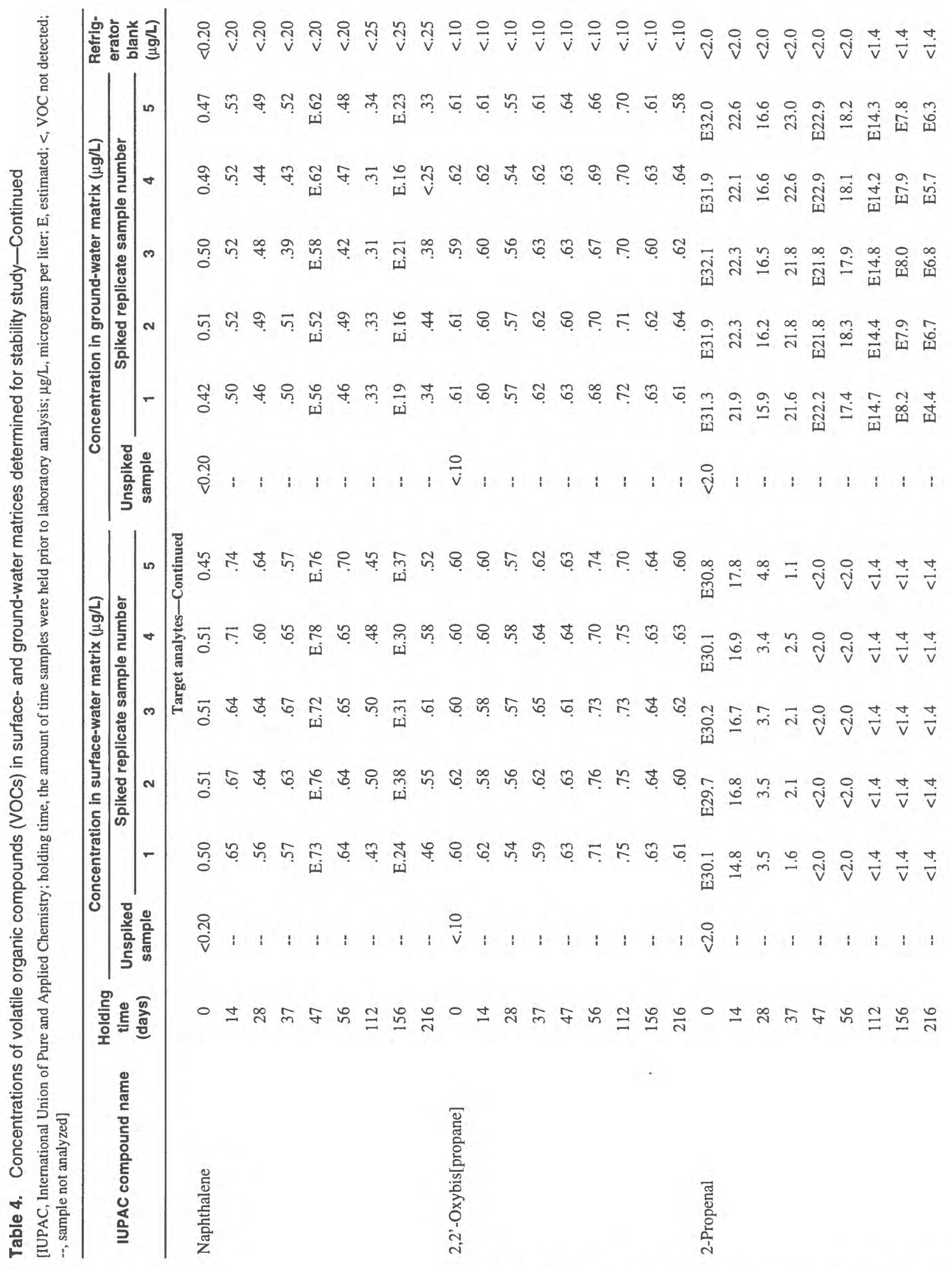




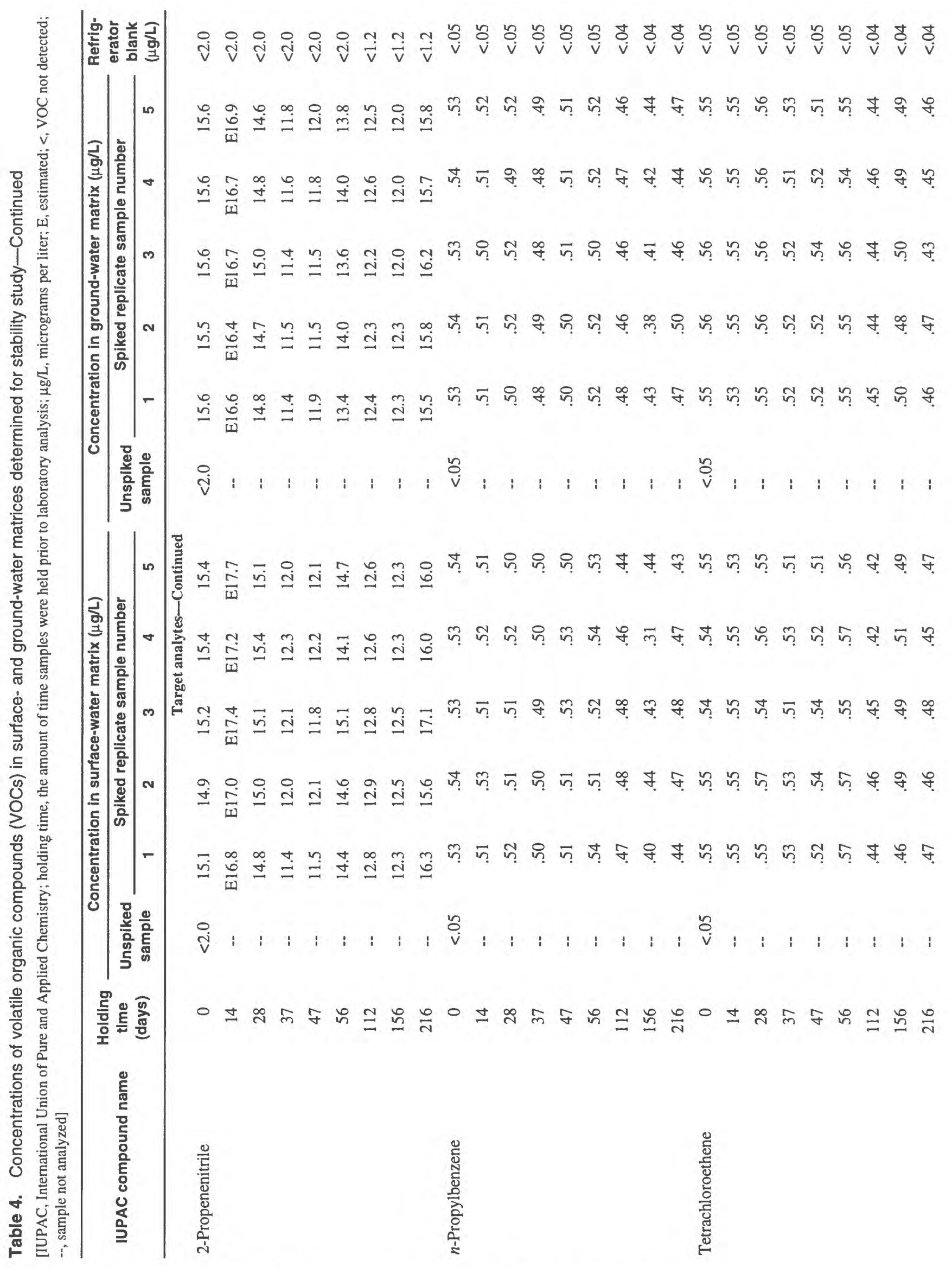




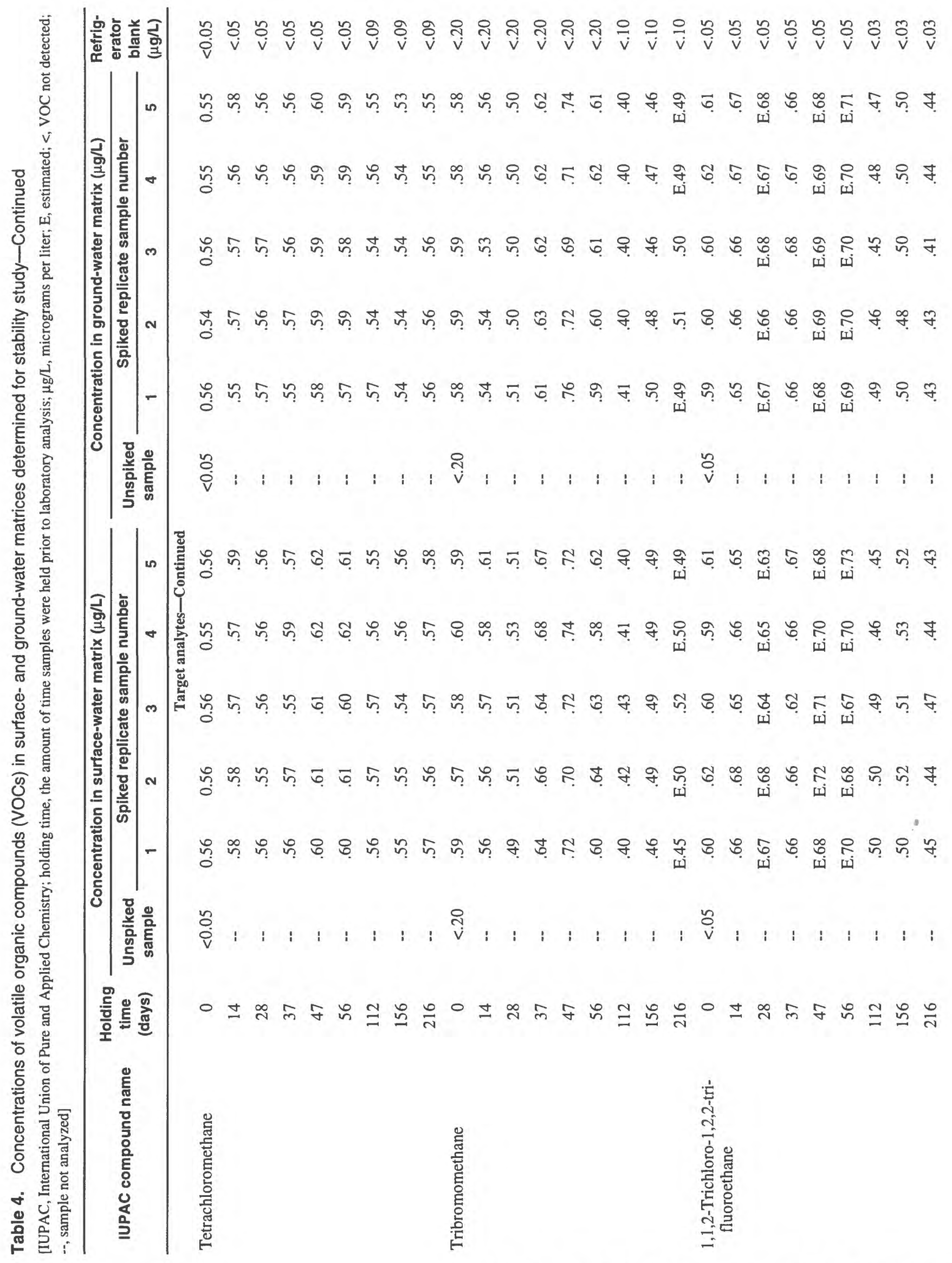




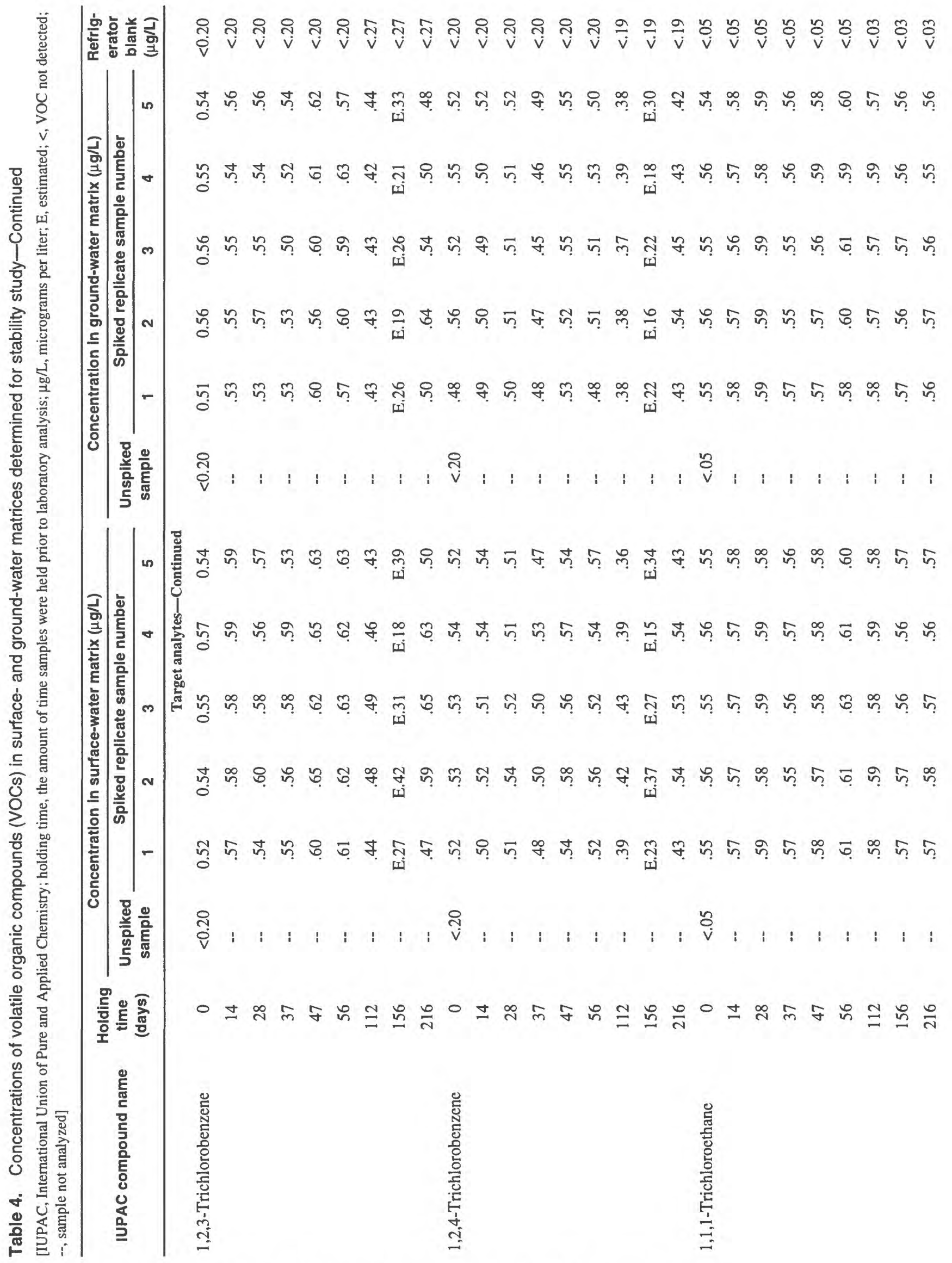




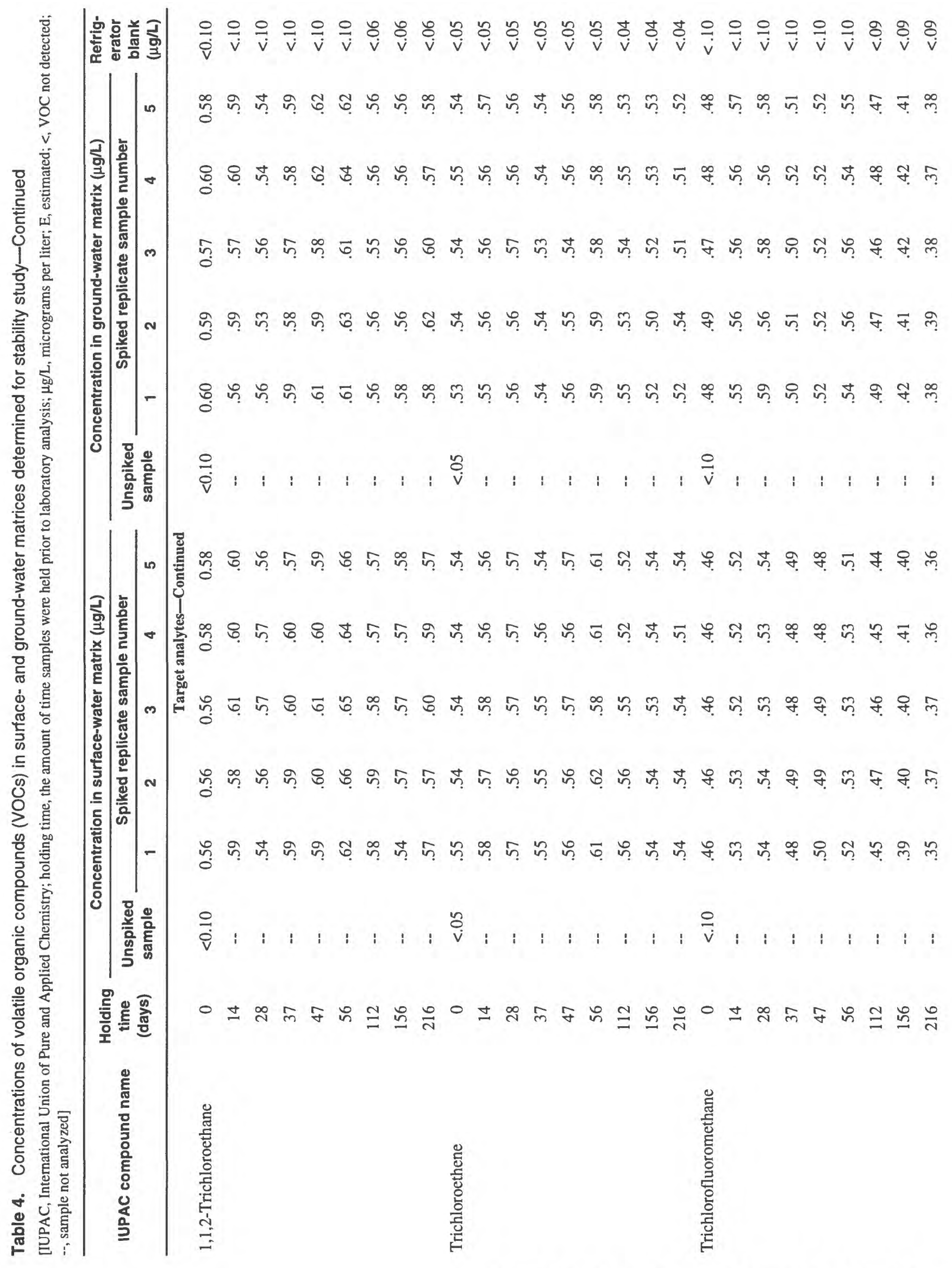




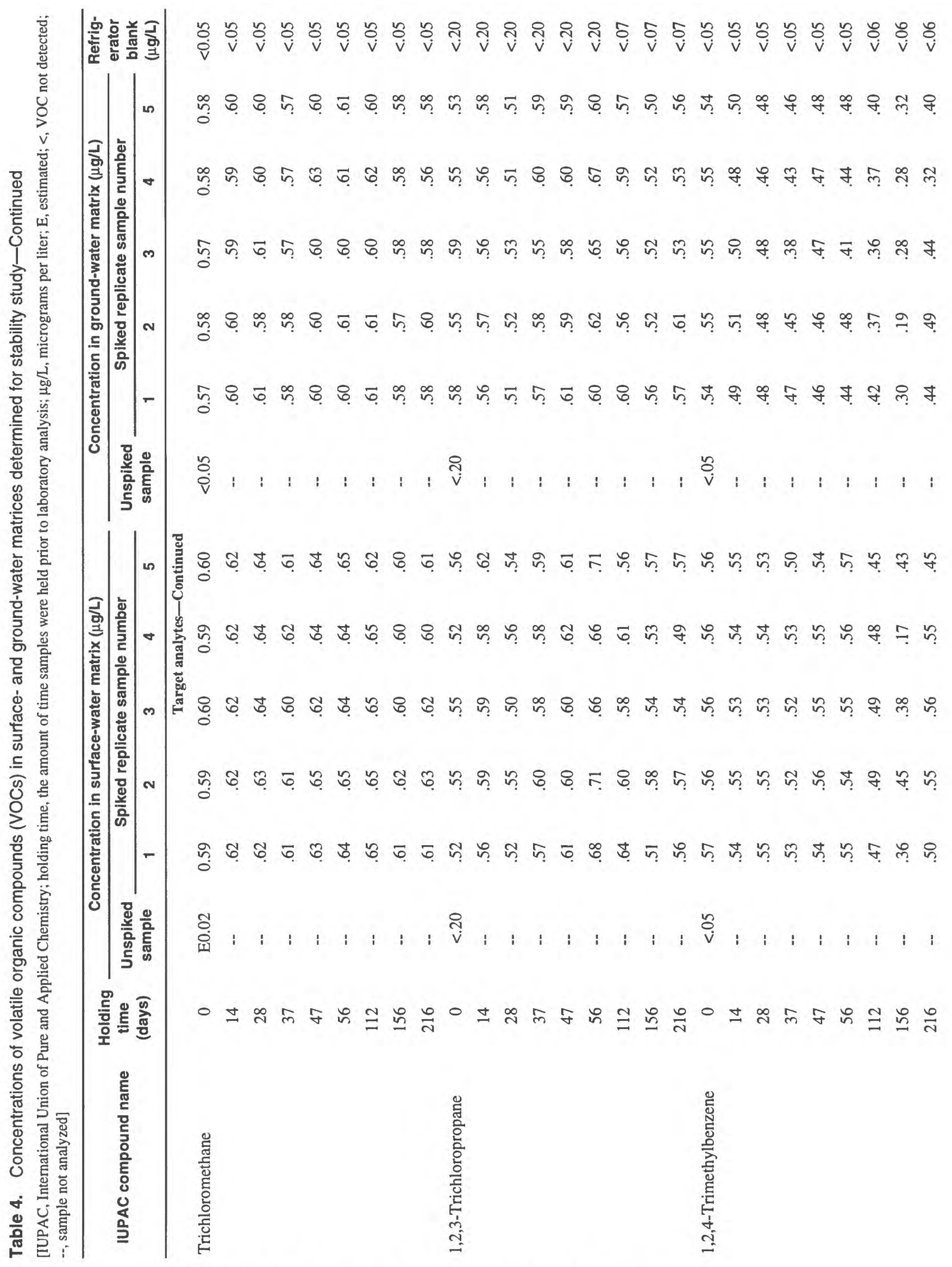




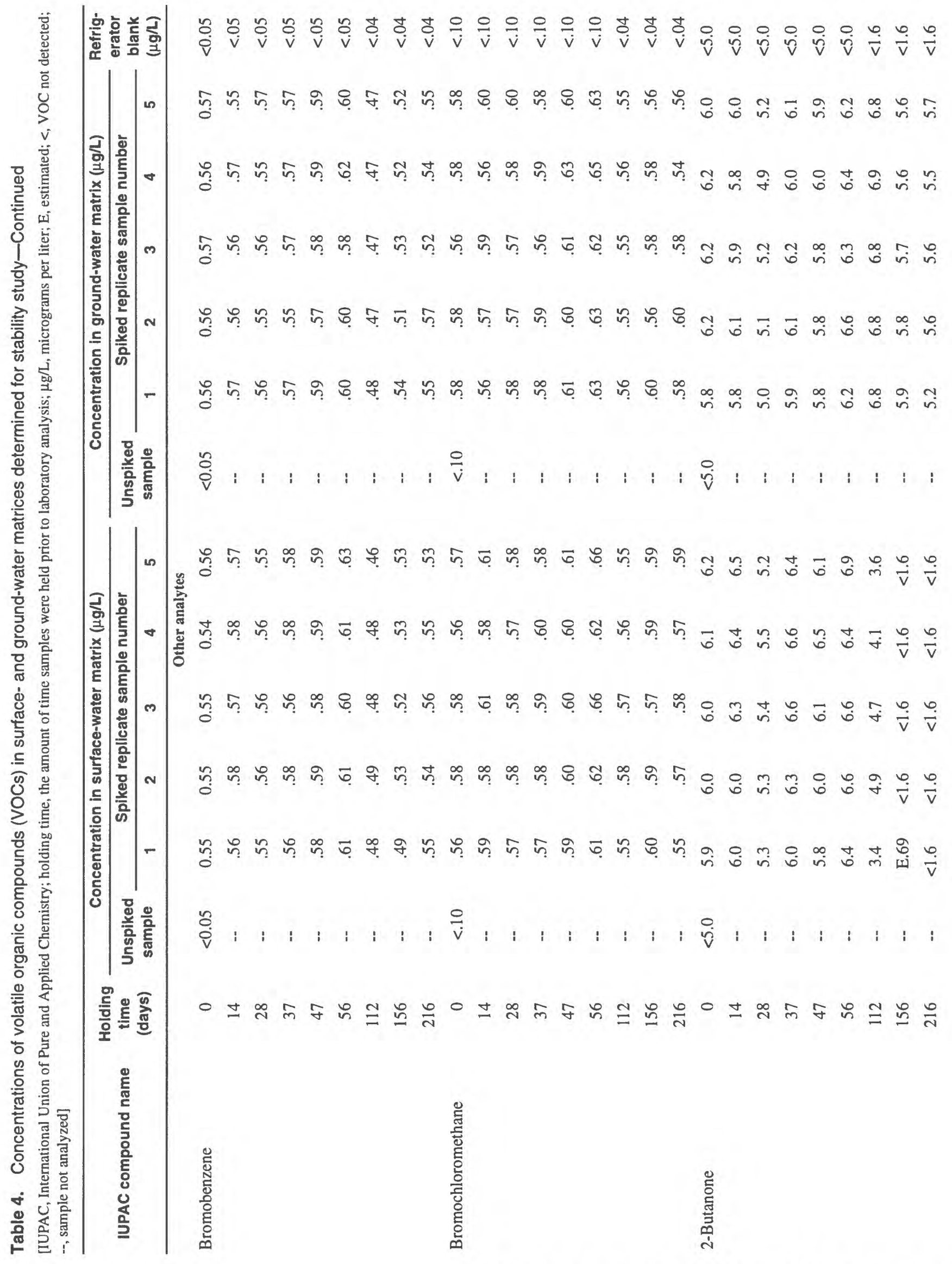




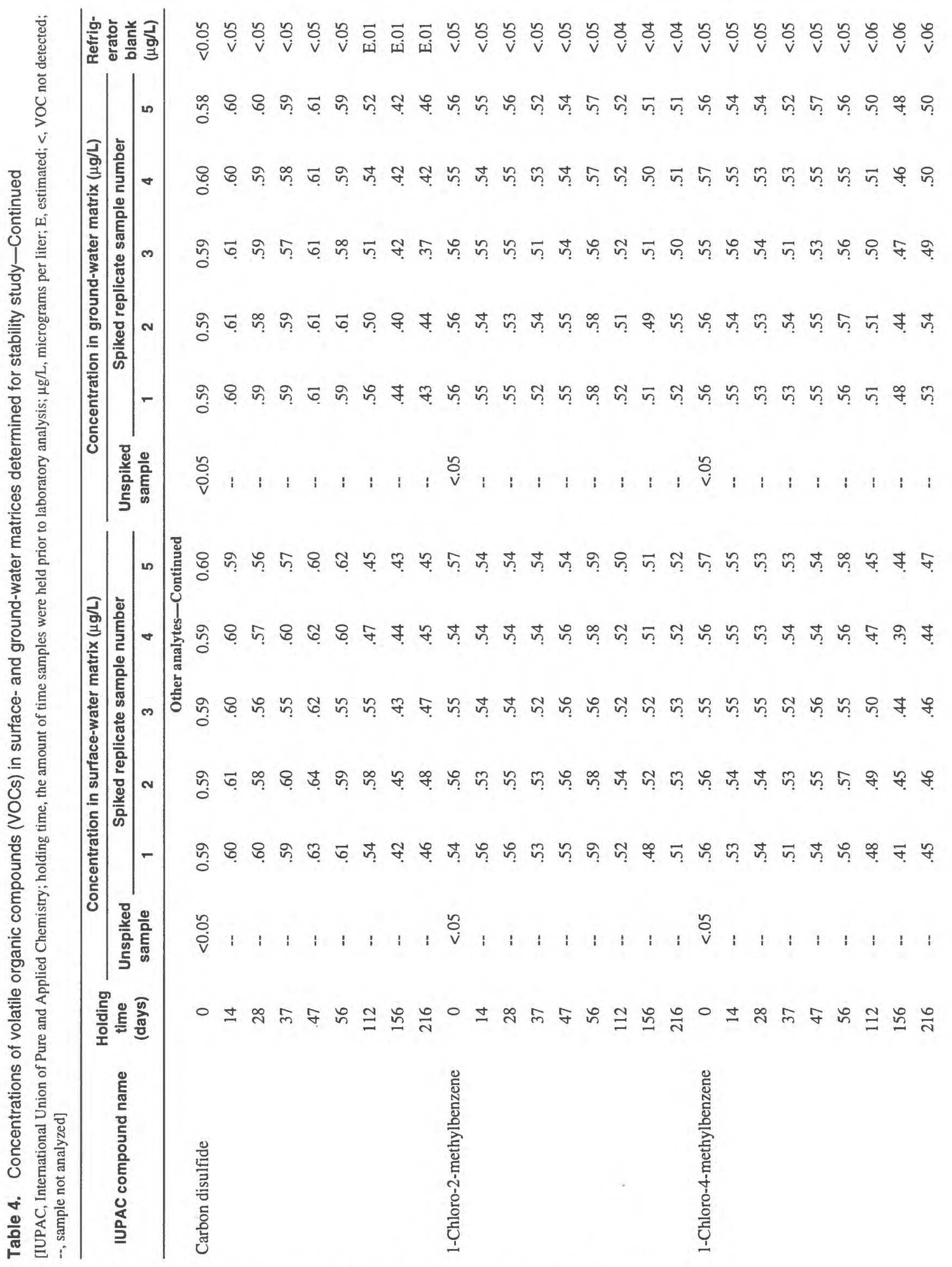




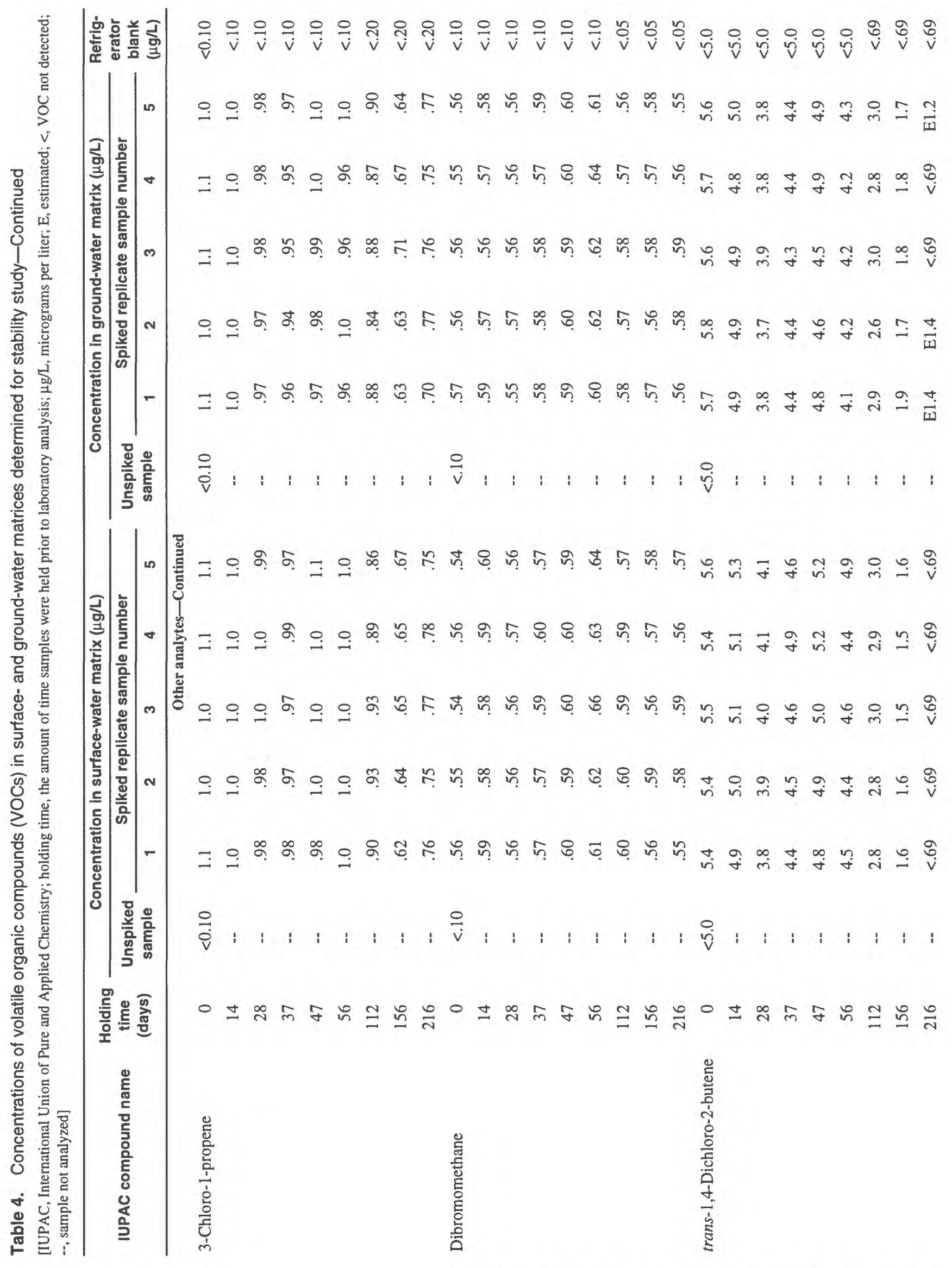




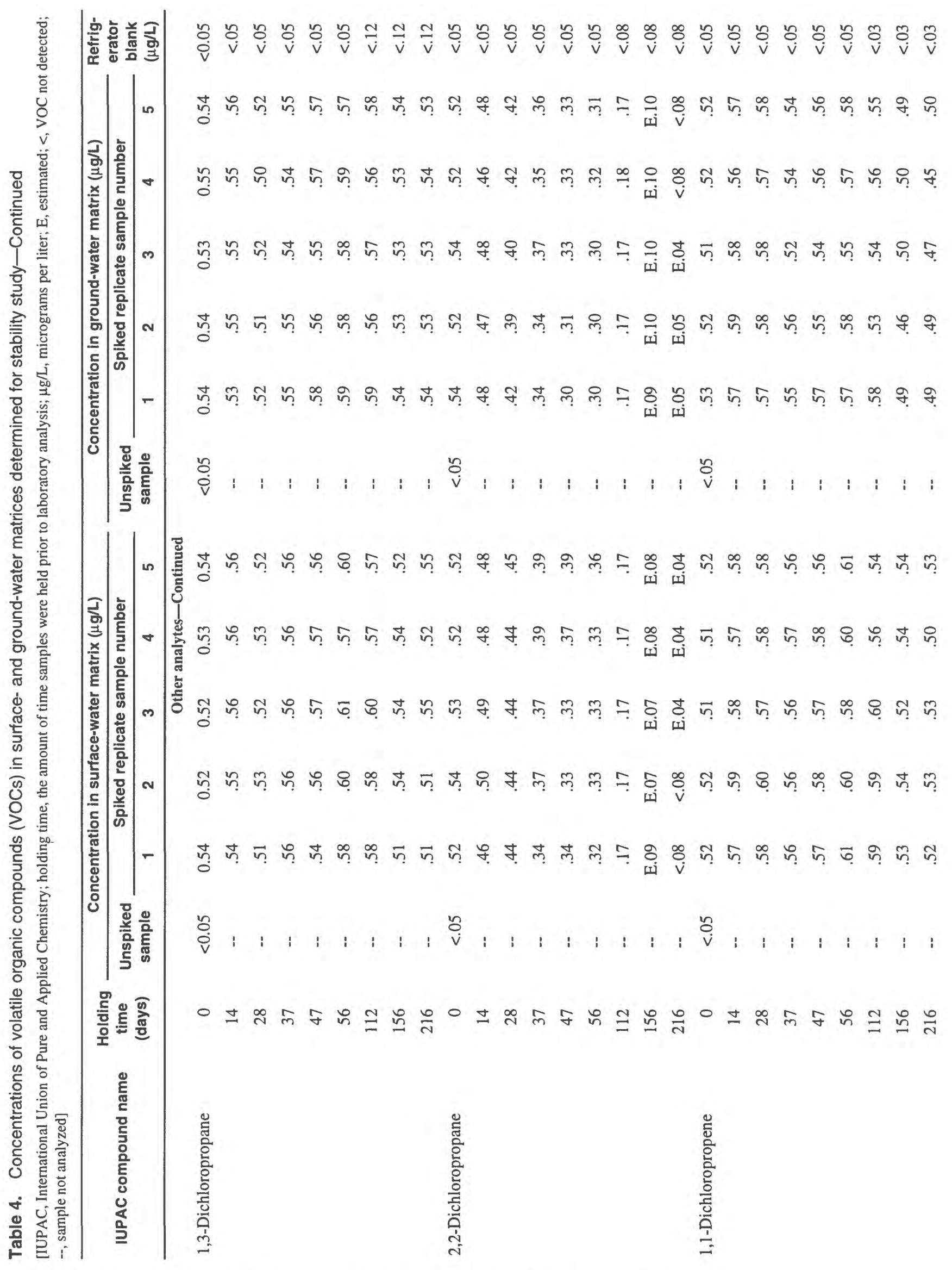



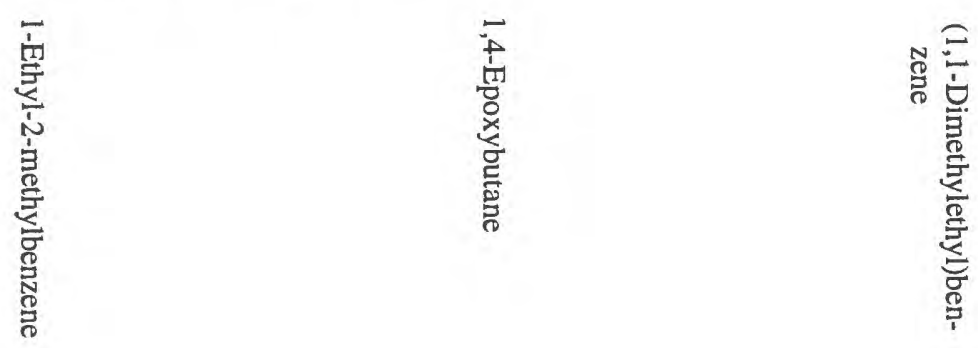

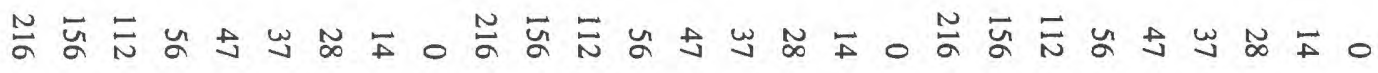

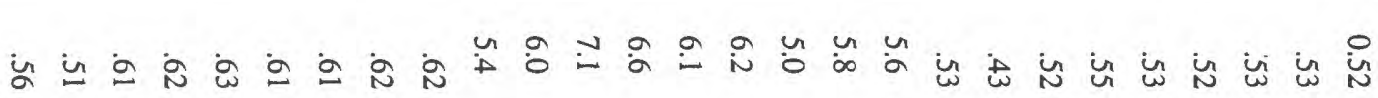

मू

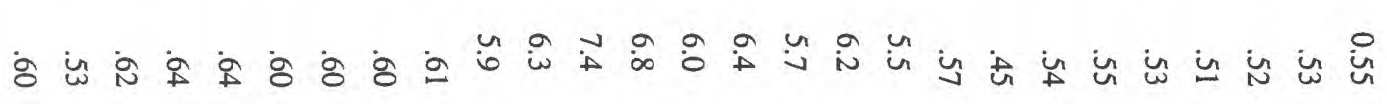

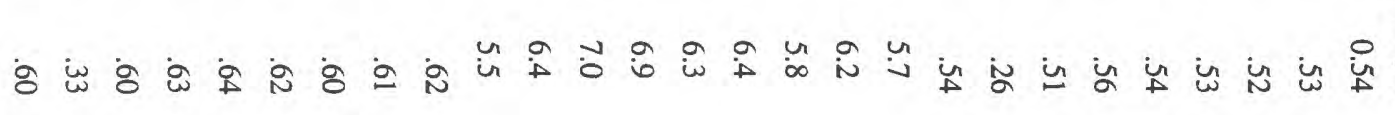

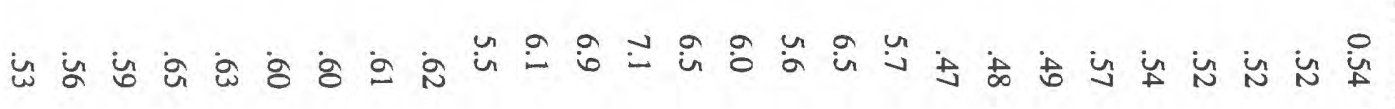

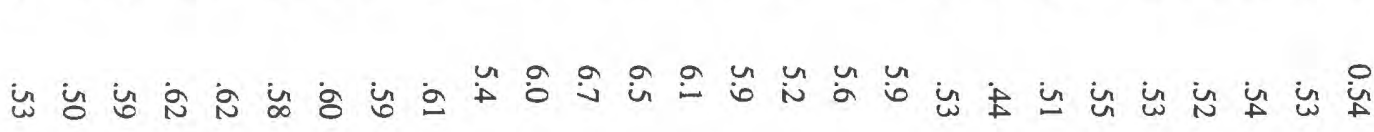

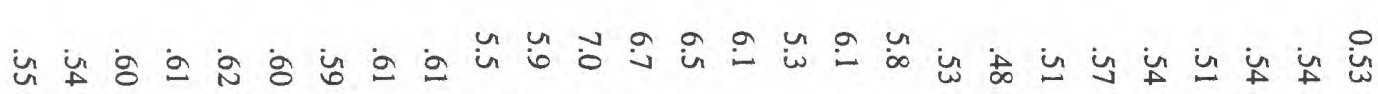

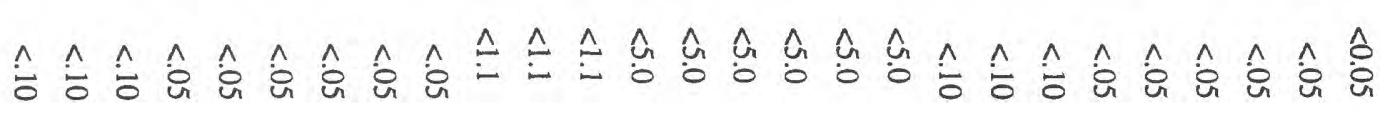

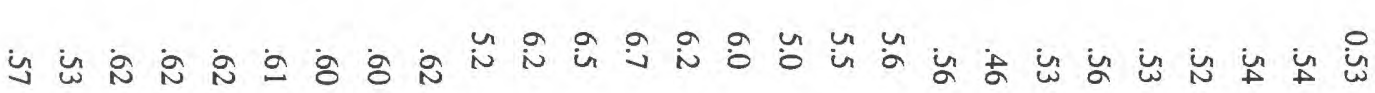

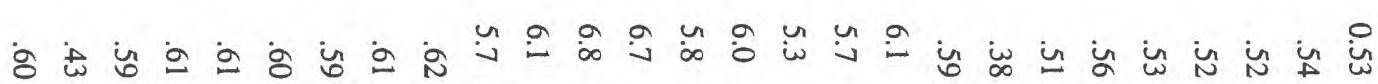

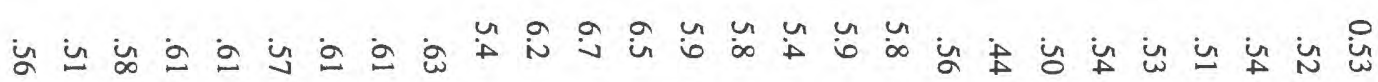




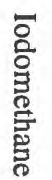

$\frac{N}{1}$
$\frac{1}{9}$
$\frac{1}{3}$
0
0

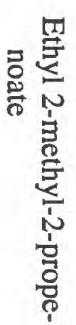

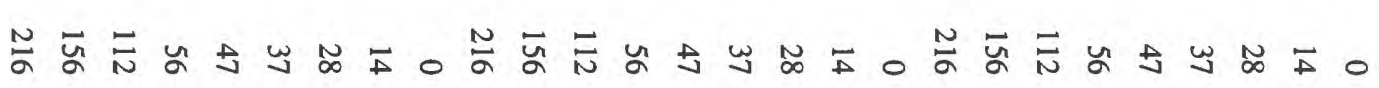

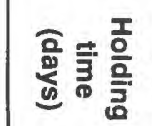

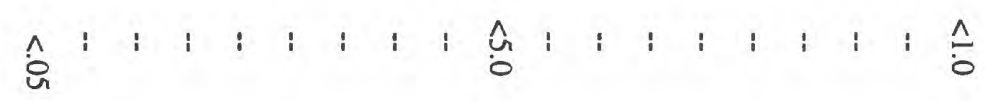

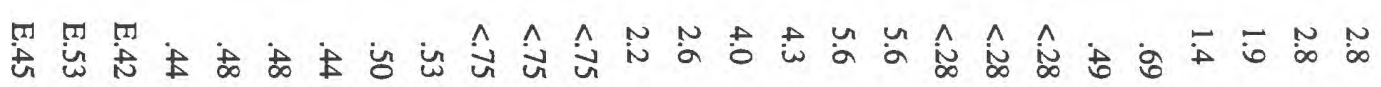

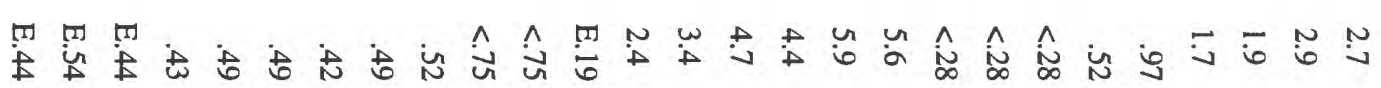

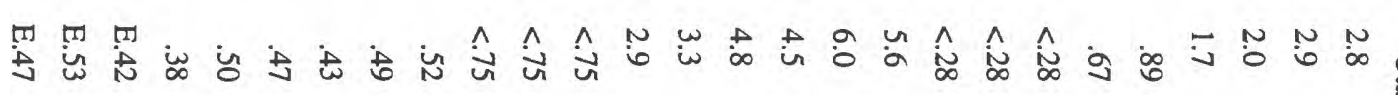

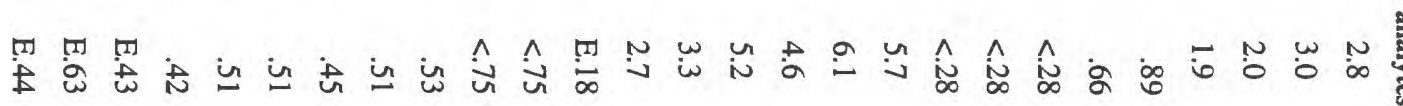

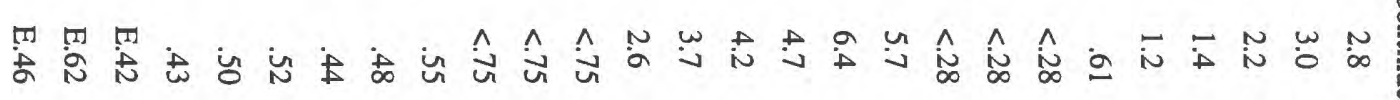

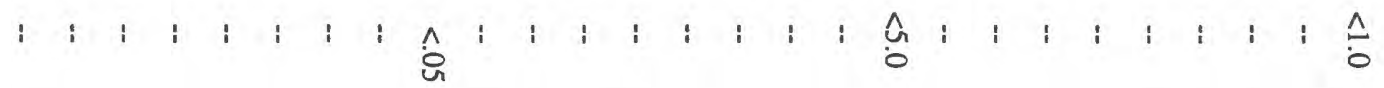

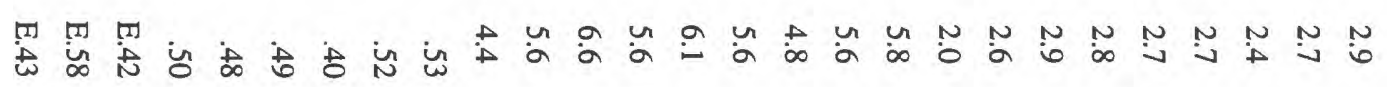

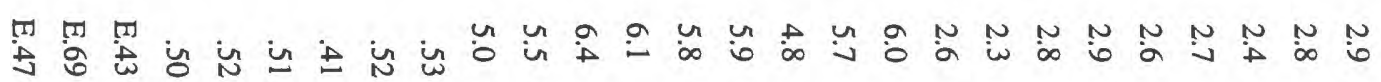

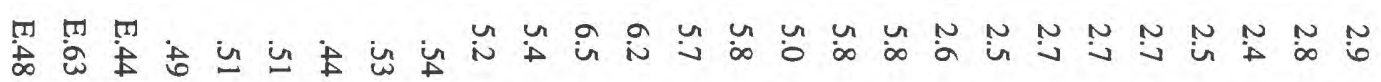

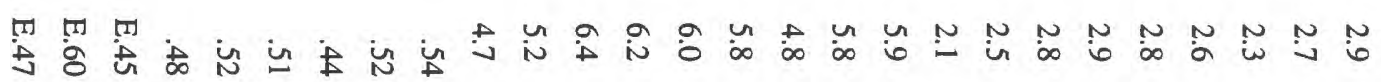

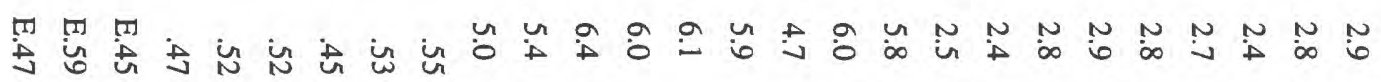

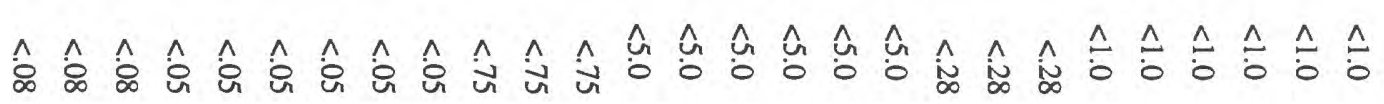



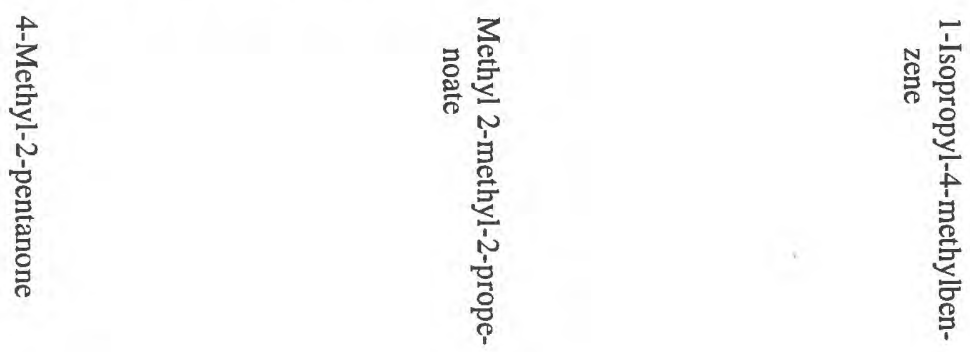

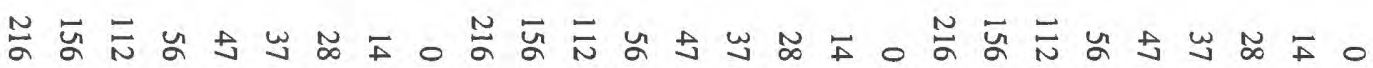
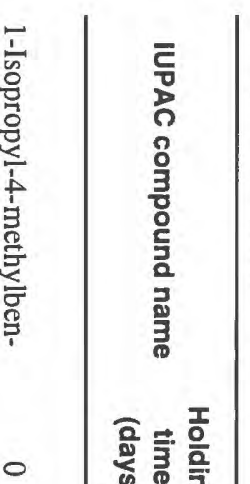

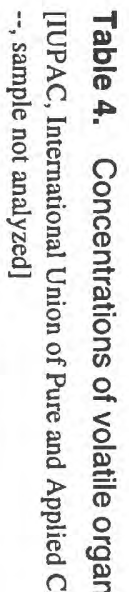

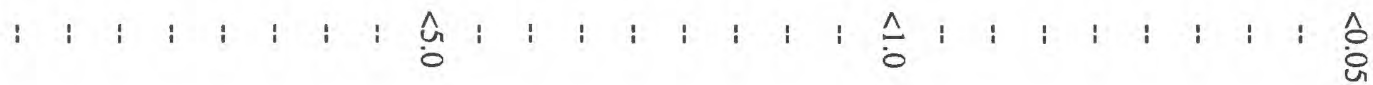

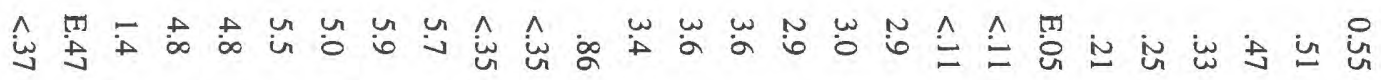

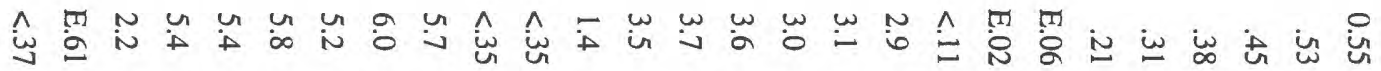

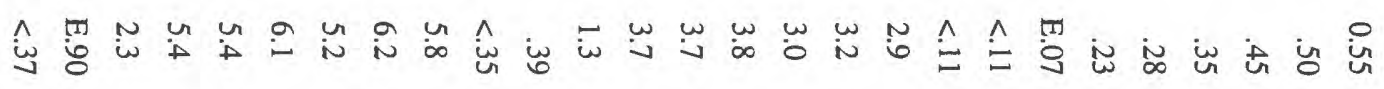

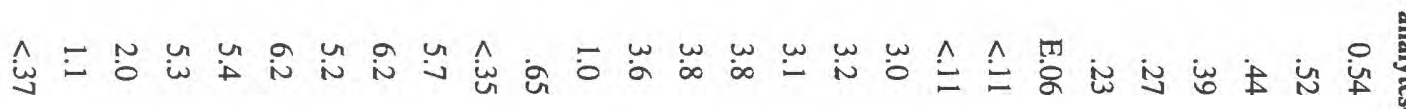

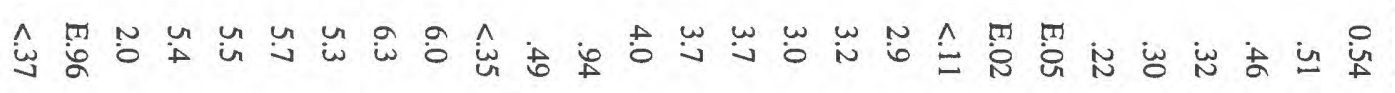

i i i i i i :

$\hat{0}$

ư

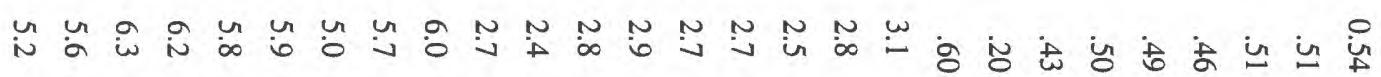

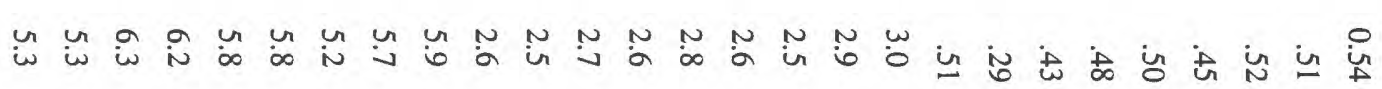

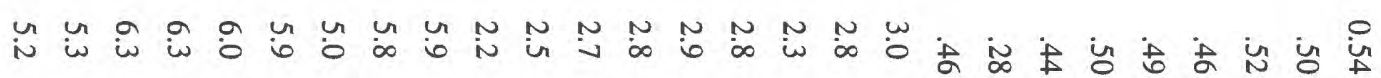

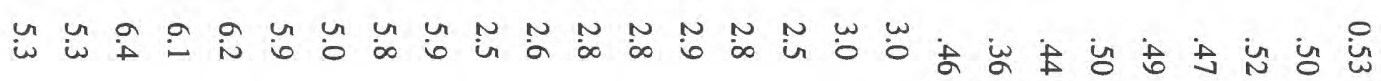

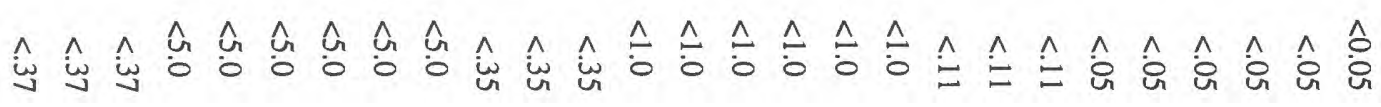




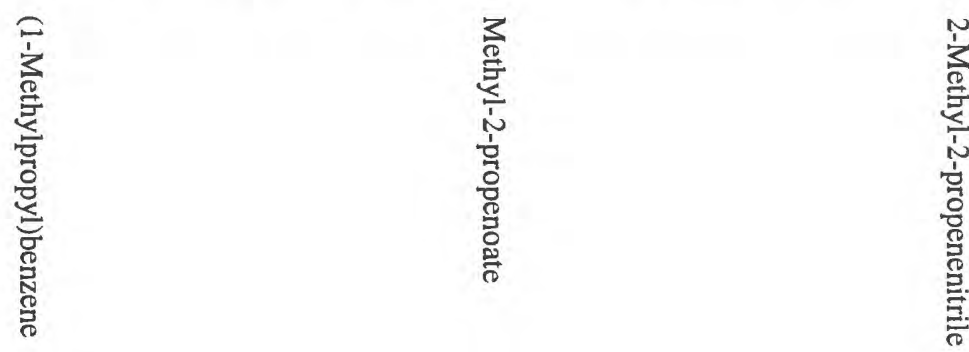

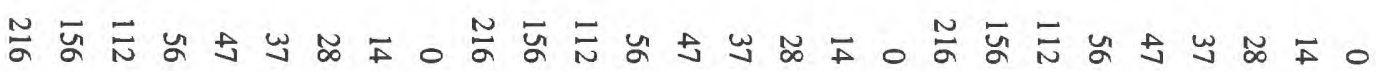

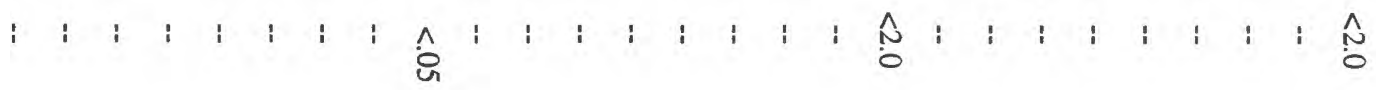
in \pm in

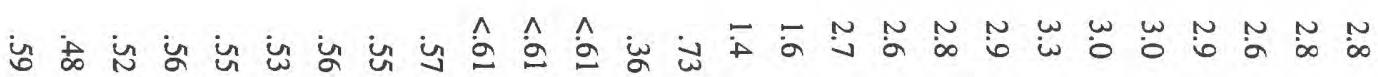
$\dot{\delta}$ 卉 in

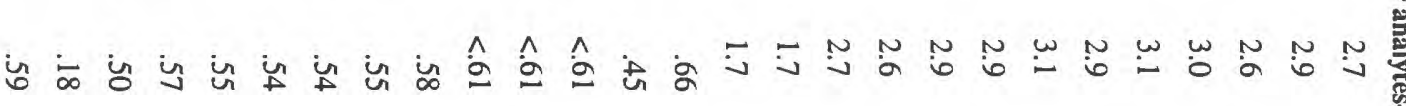

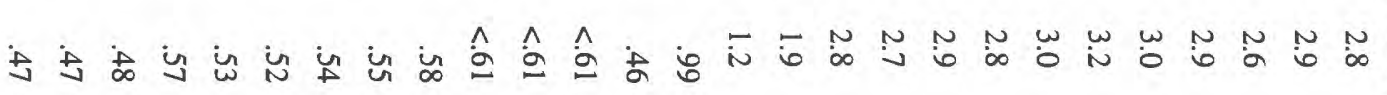
i i i i i i

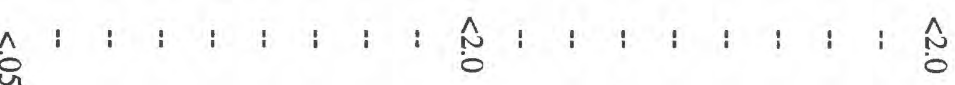

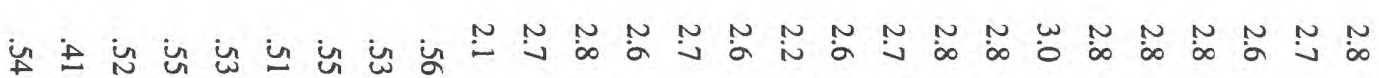
$\dot{8} \dot{0}$ 행

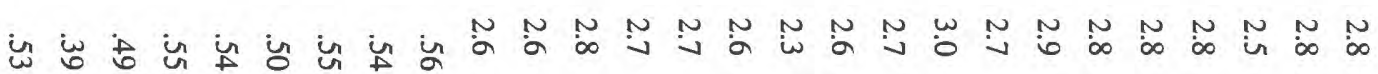
in

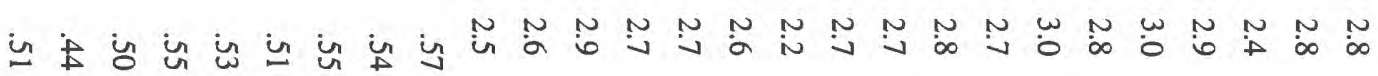

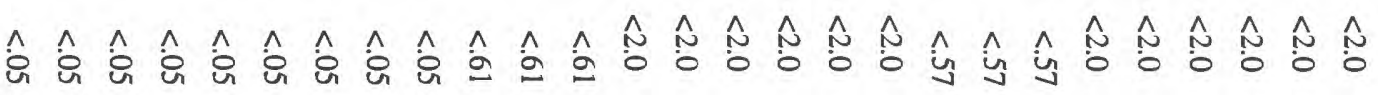




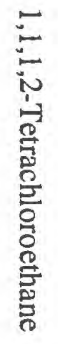

슴 है

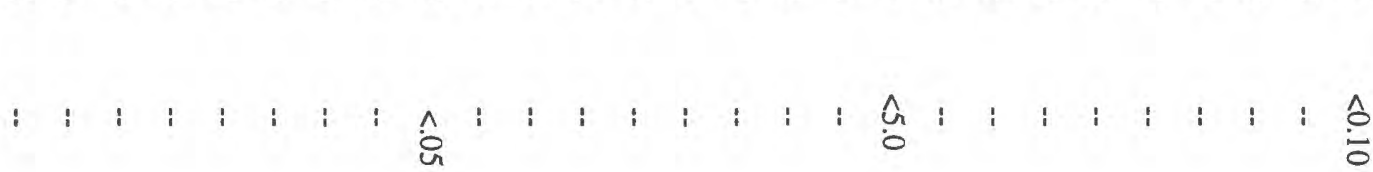

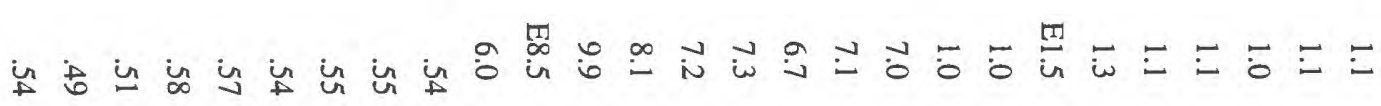
in in in in in un w in in i

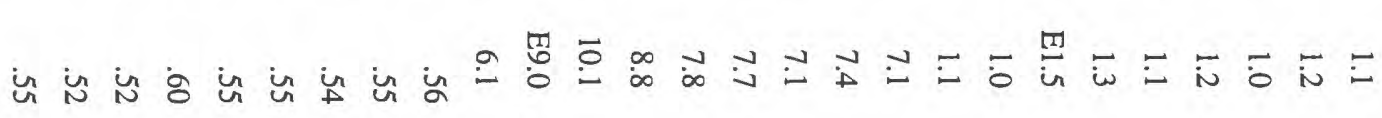
in in in in in un un in in

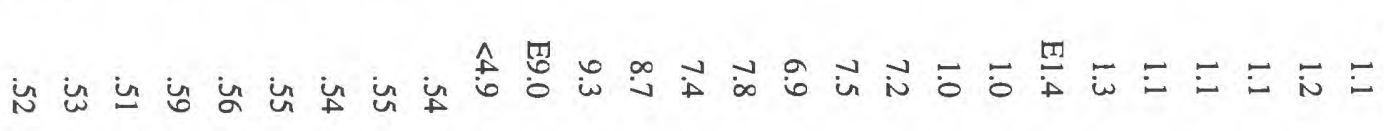

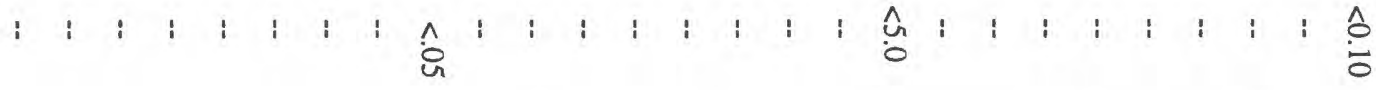

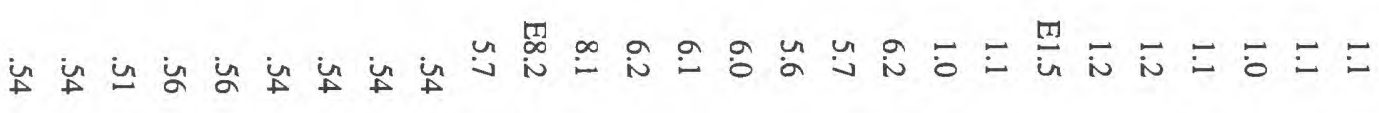

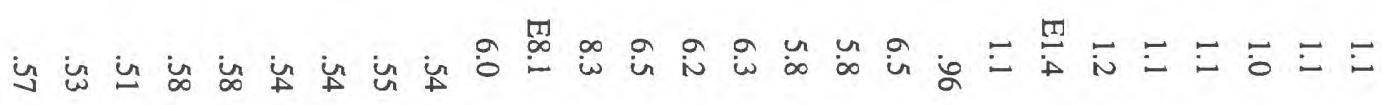
in

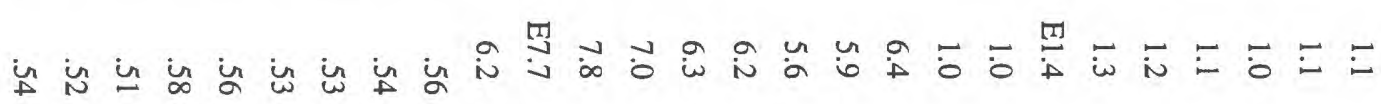

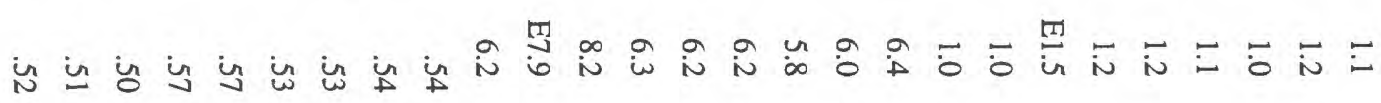

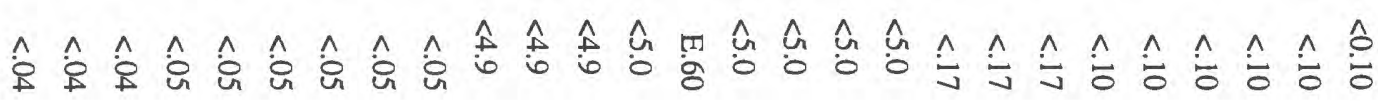



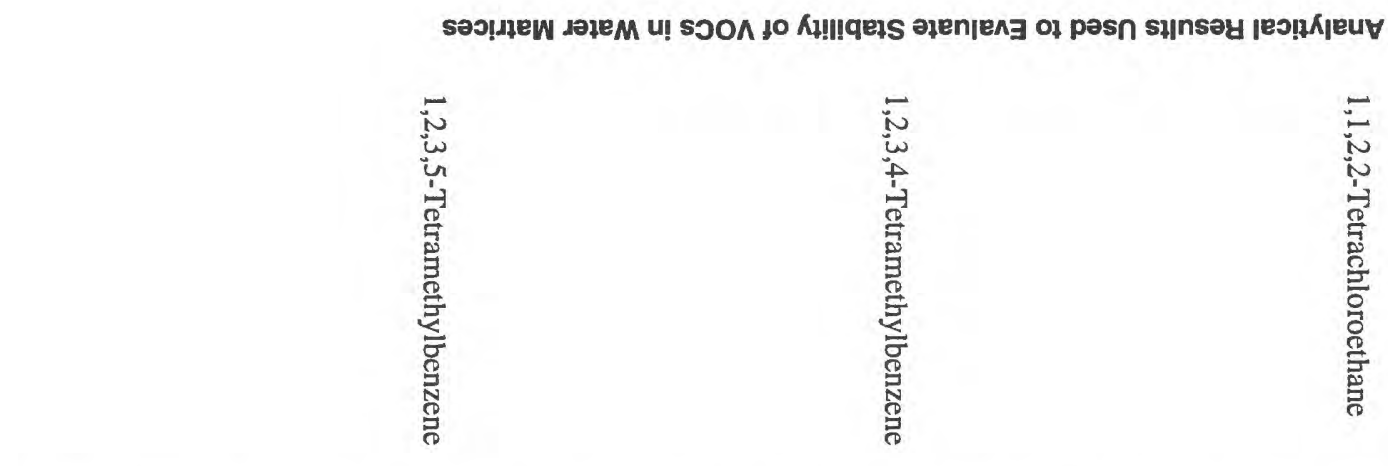

츰 $\bar{N}$ 少

$$
\hat{\circ}
$$

部 in in

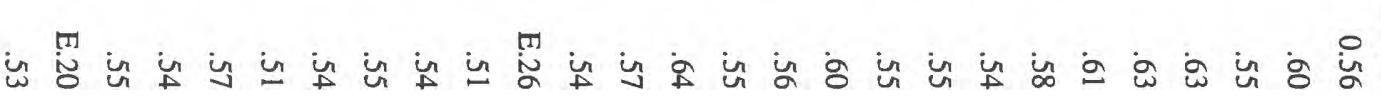

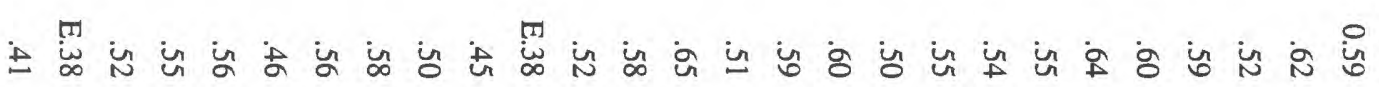
$\hat{\text { i }}$

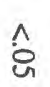
$\hat{o}$ i

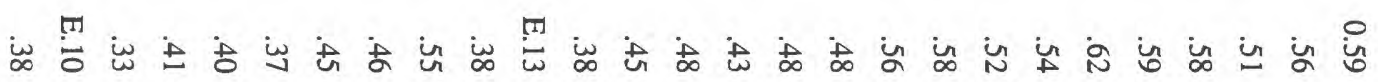
i

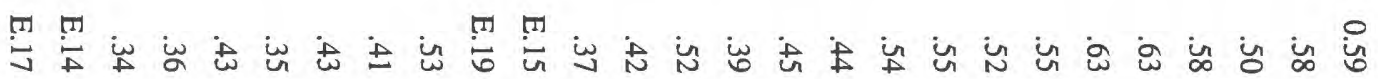
벙

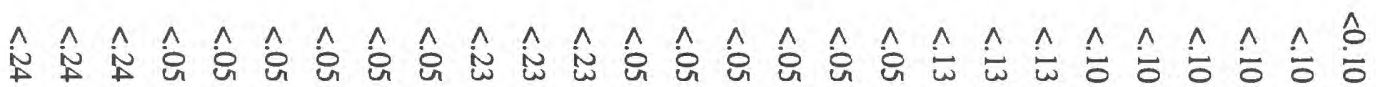

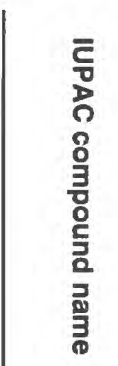

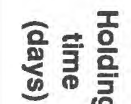

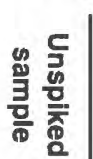

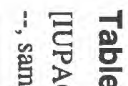
亭

후을

롤 วิ 


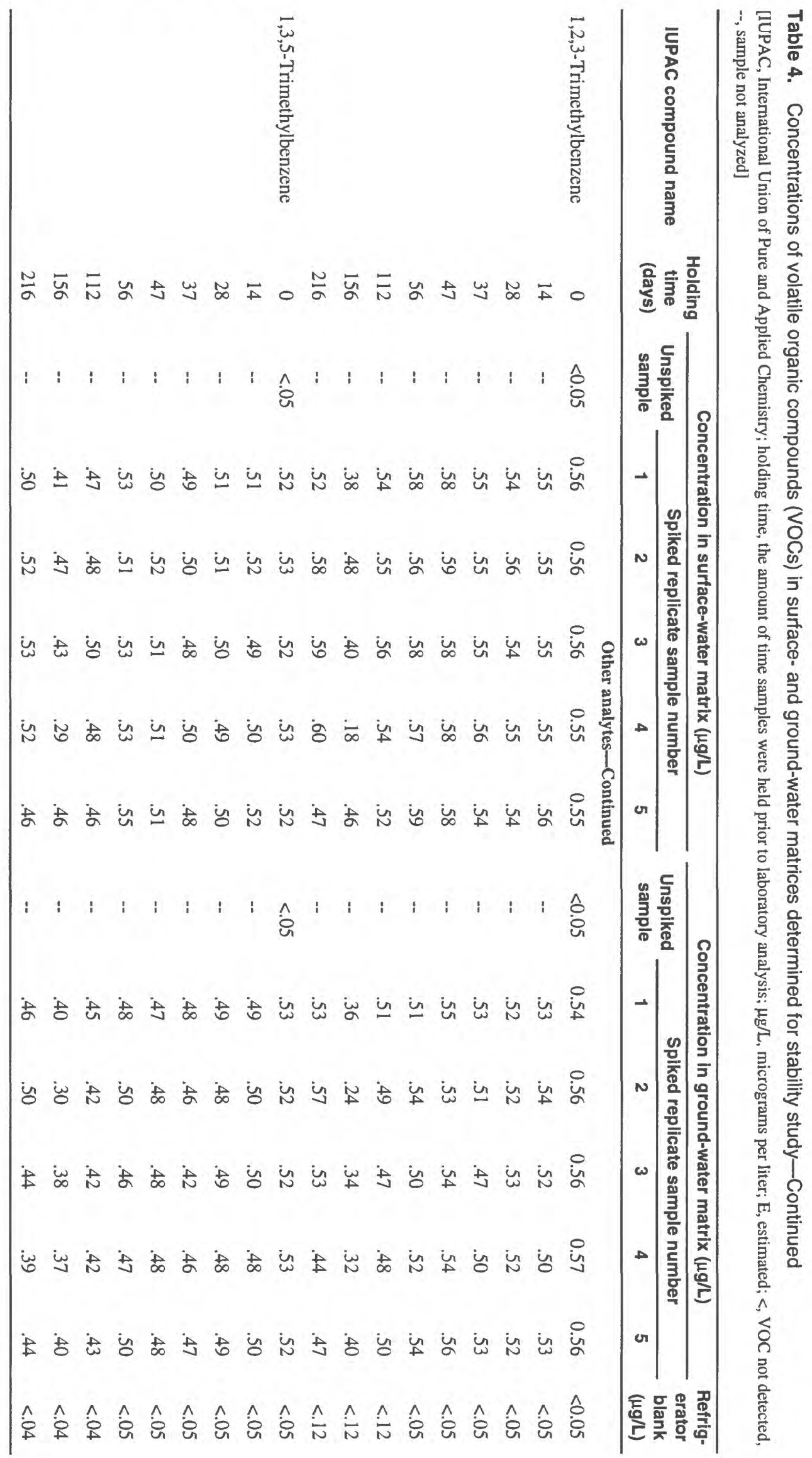




\section{Section B - Plots of concentration data for volatile organic compounds in surface- and ground-water matrices and continuing calibration verification data}

Note: Graphical plots of concentration data consists of five replicate samples of each water matrix and three replicate samples for continuing calibration verification standards analyzed on days $0,14,28,37,47,56,112,156,216$.

EXPLANATION

Largest value within 1.5 interquartile ranges above the 75 th percentile

75th percentile value

50 th percent value (median)

25th percentile value

Smallest value within 1.5 interquartile ranges below the 75 th percentile 

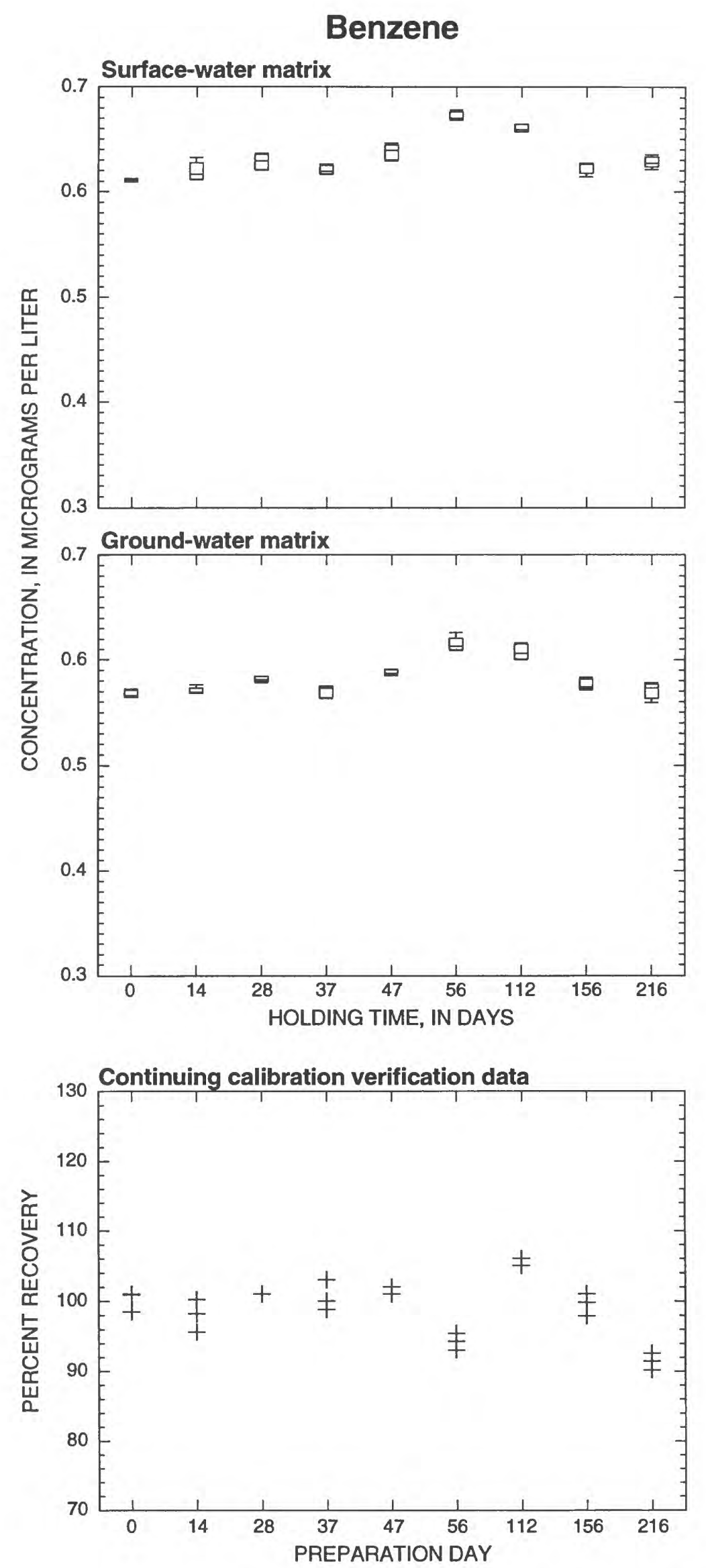

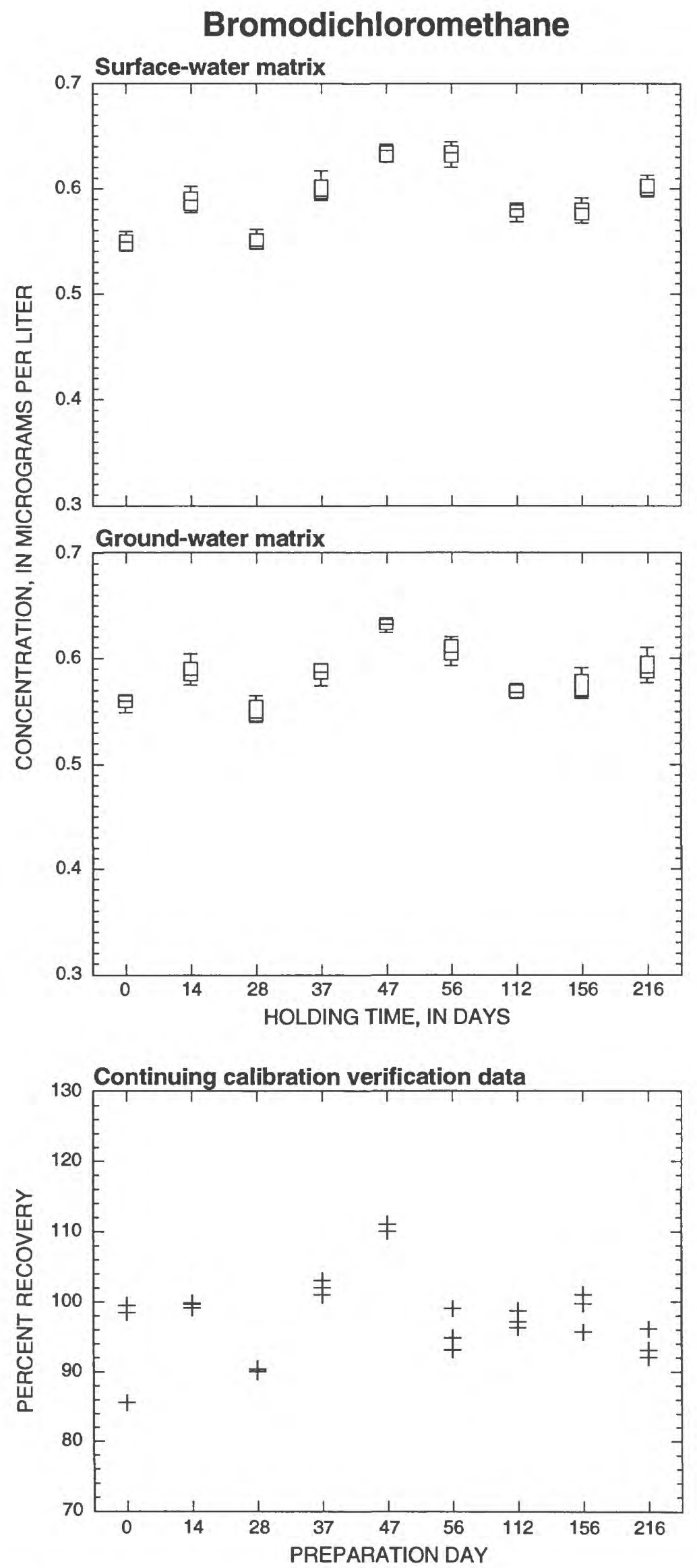


\section{Bromoethene}
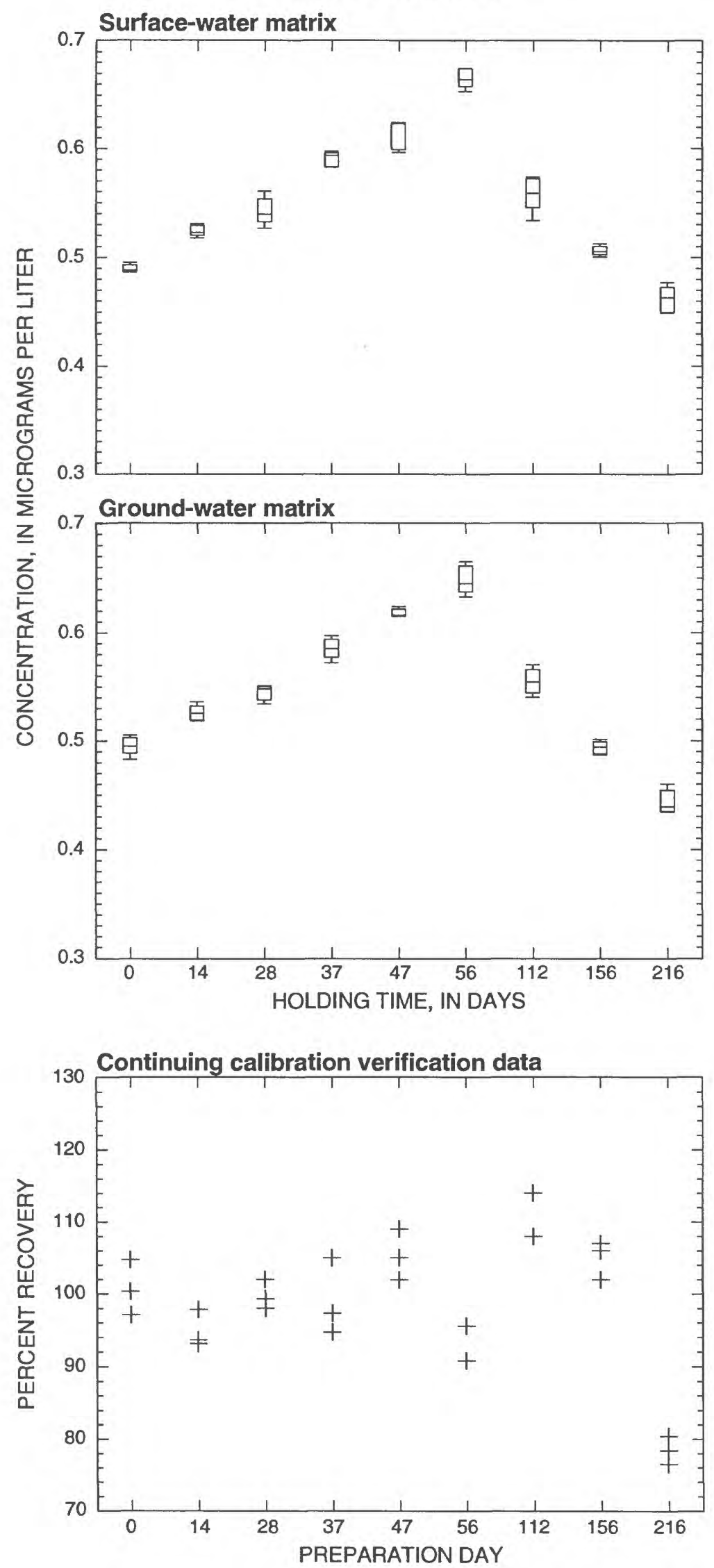
Bromomethane
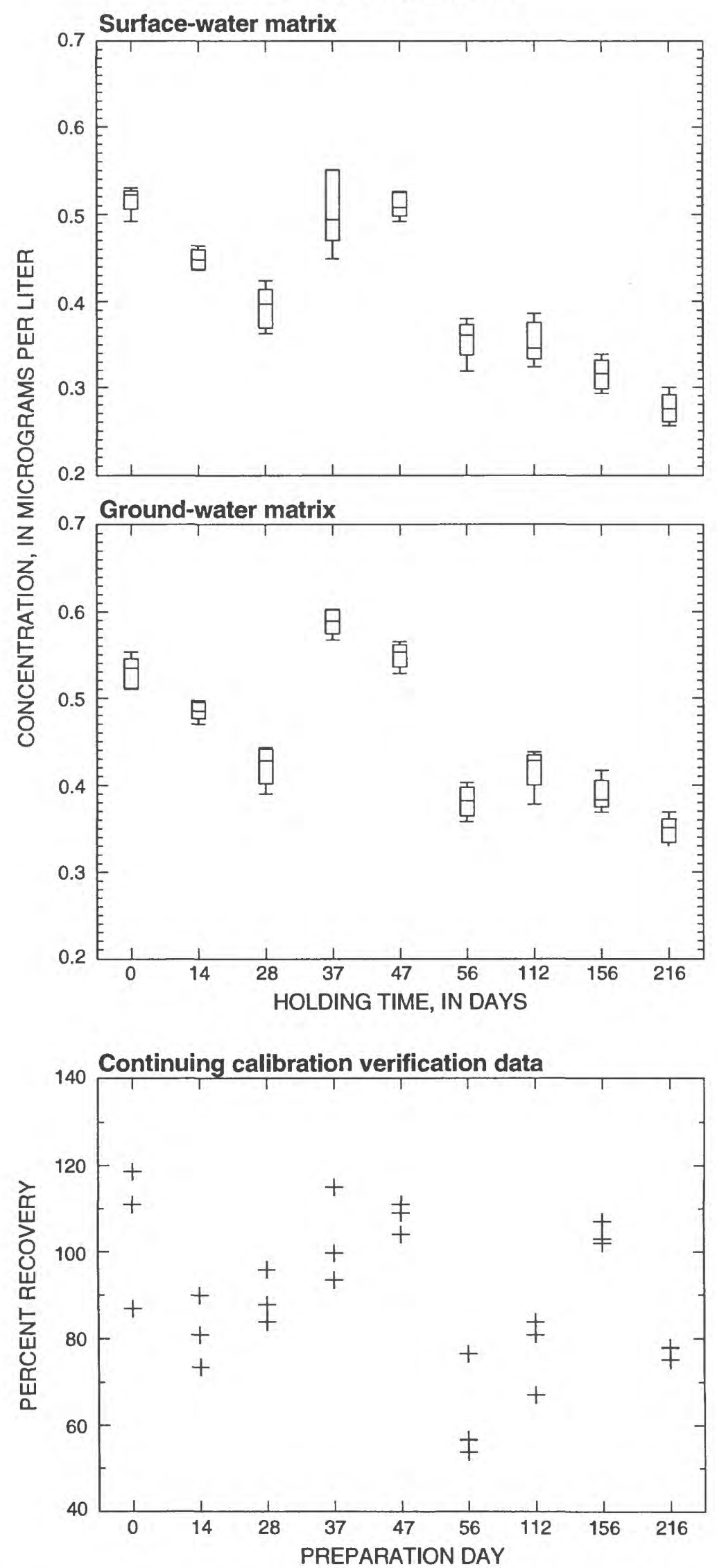

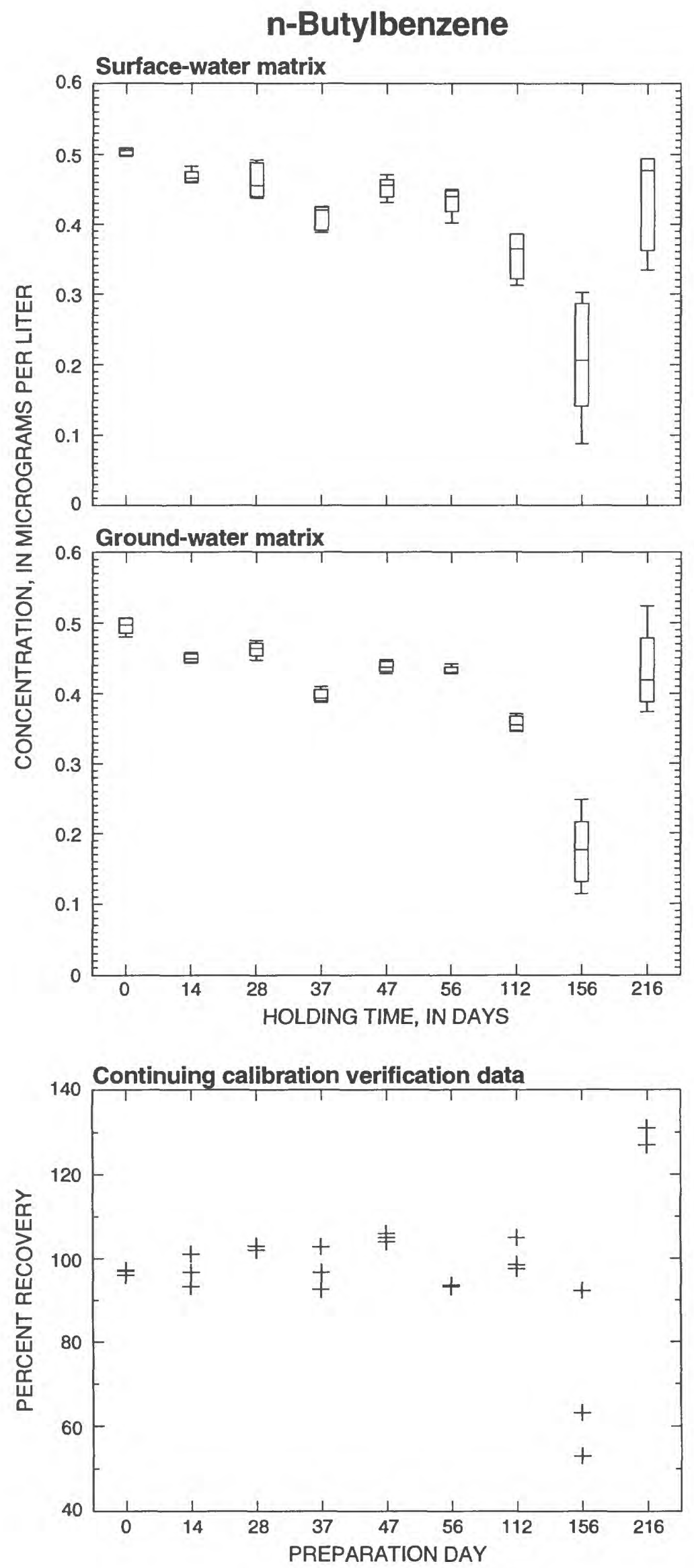
Chlorobenzene
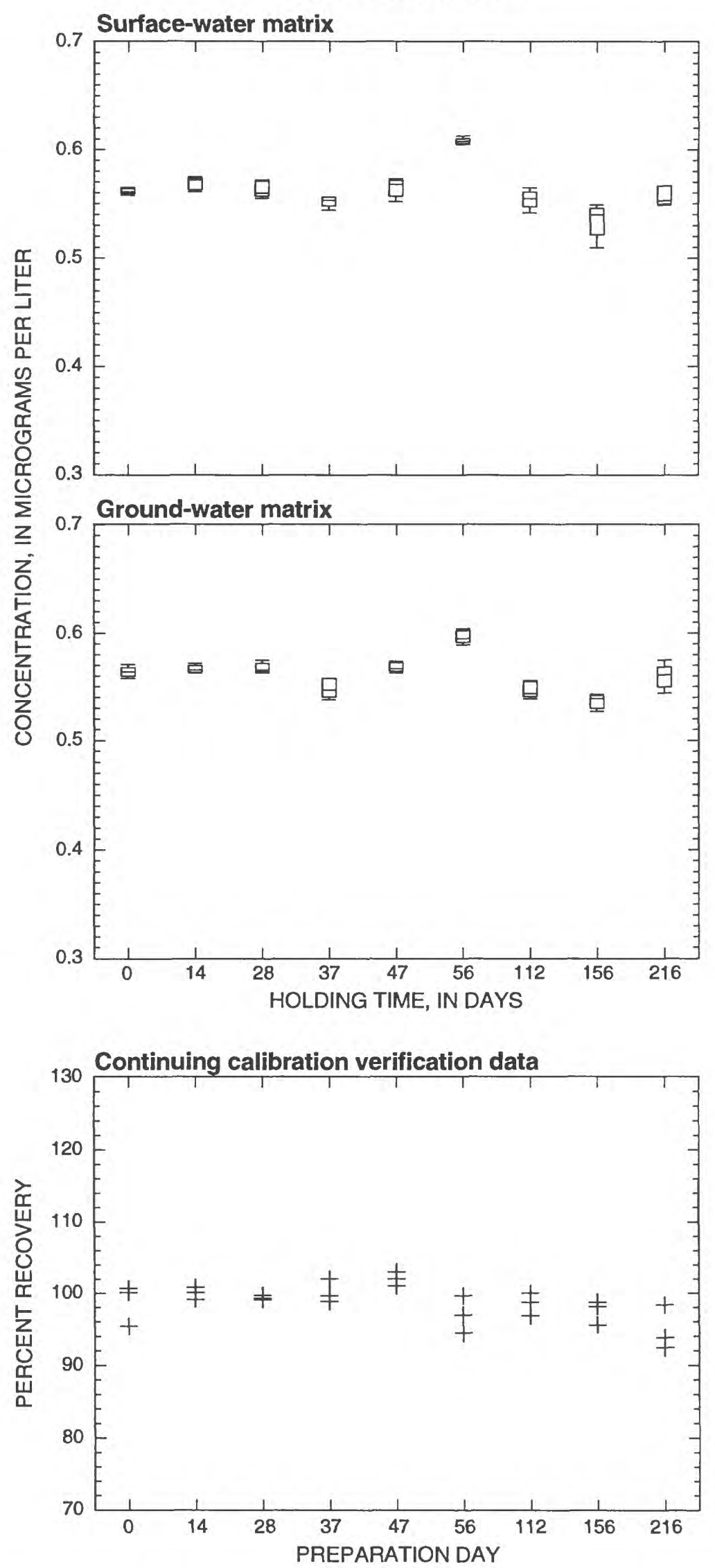
Chloroethane
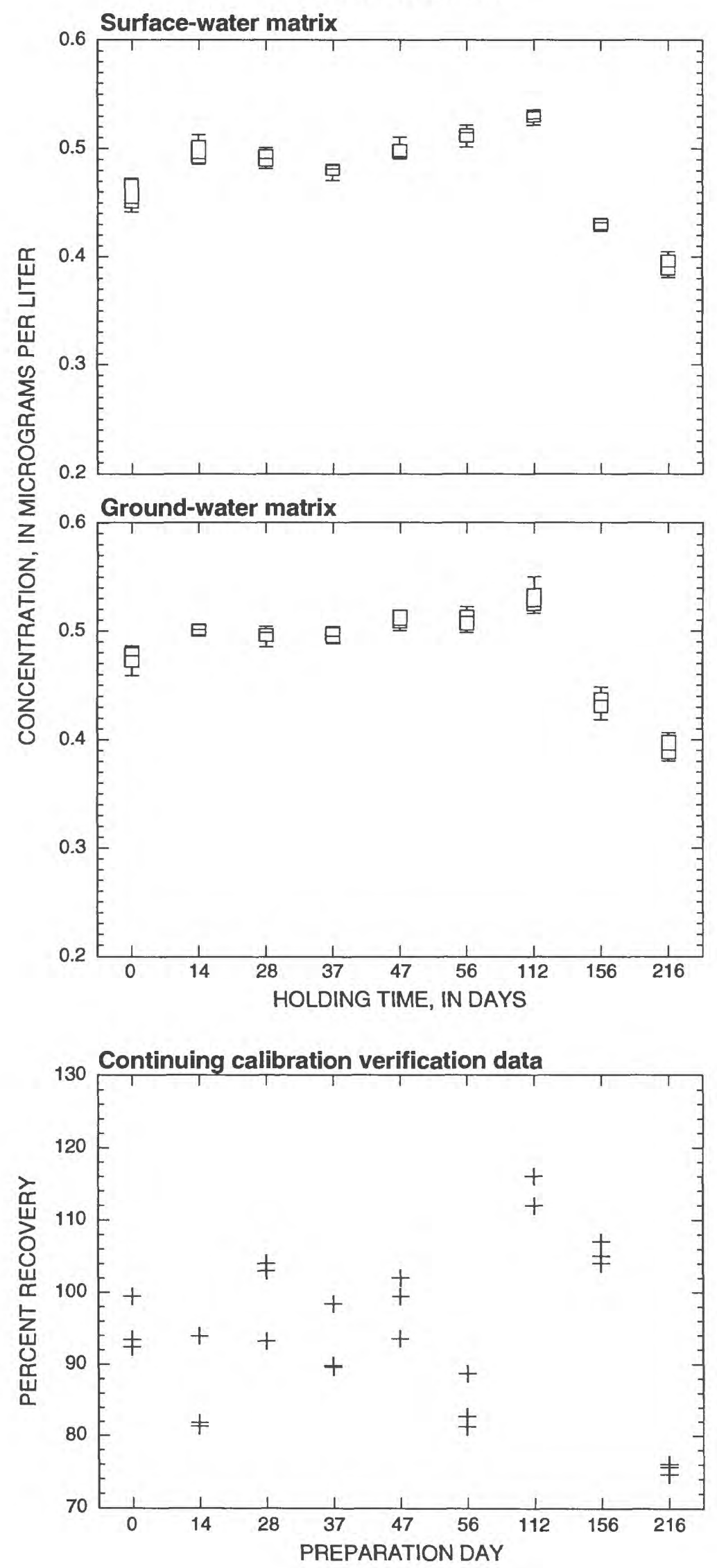
Chloroethene
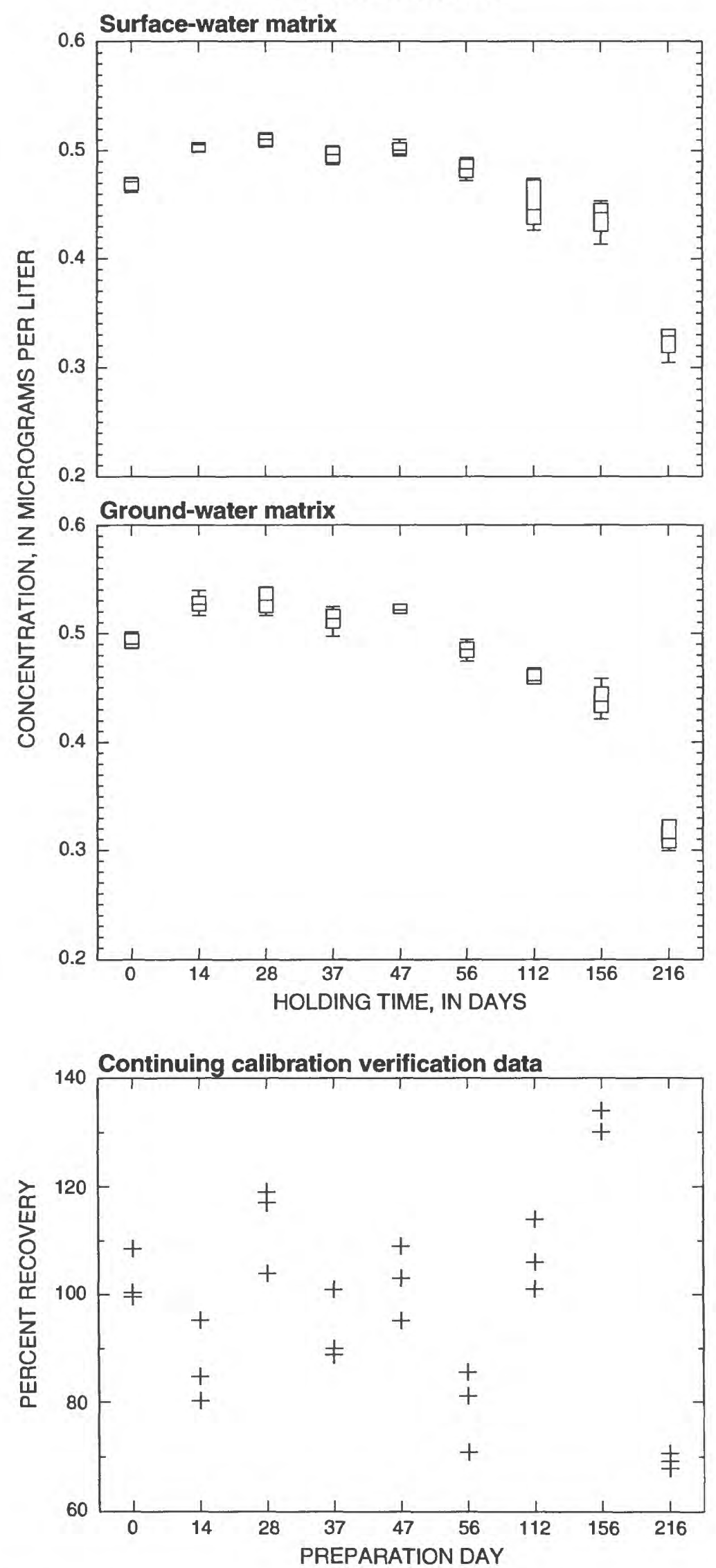
Chloromethane
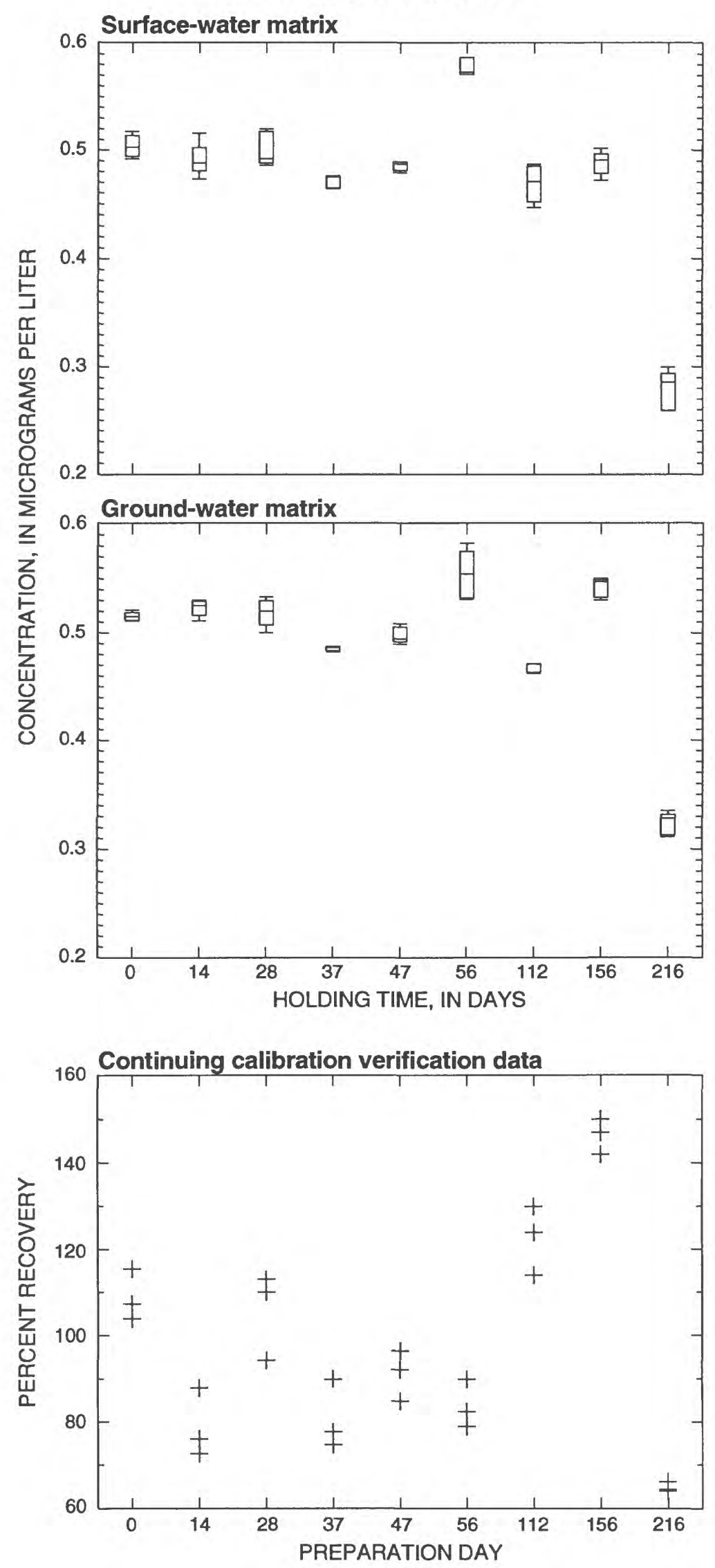
1,2-Dibromo-3-chloropropane
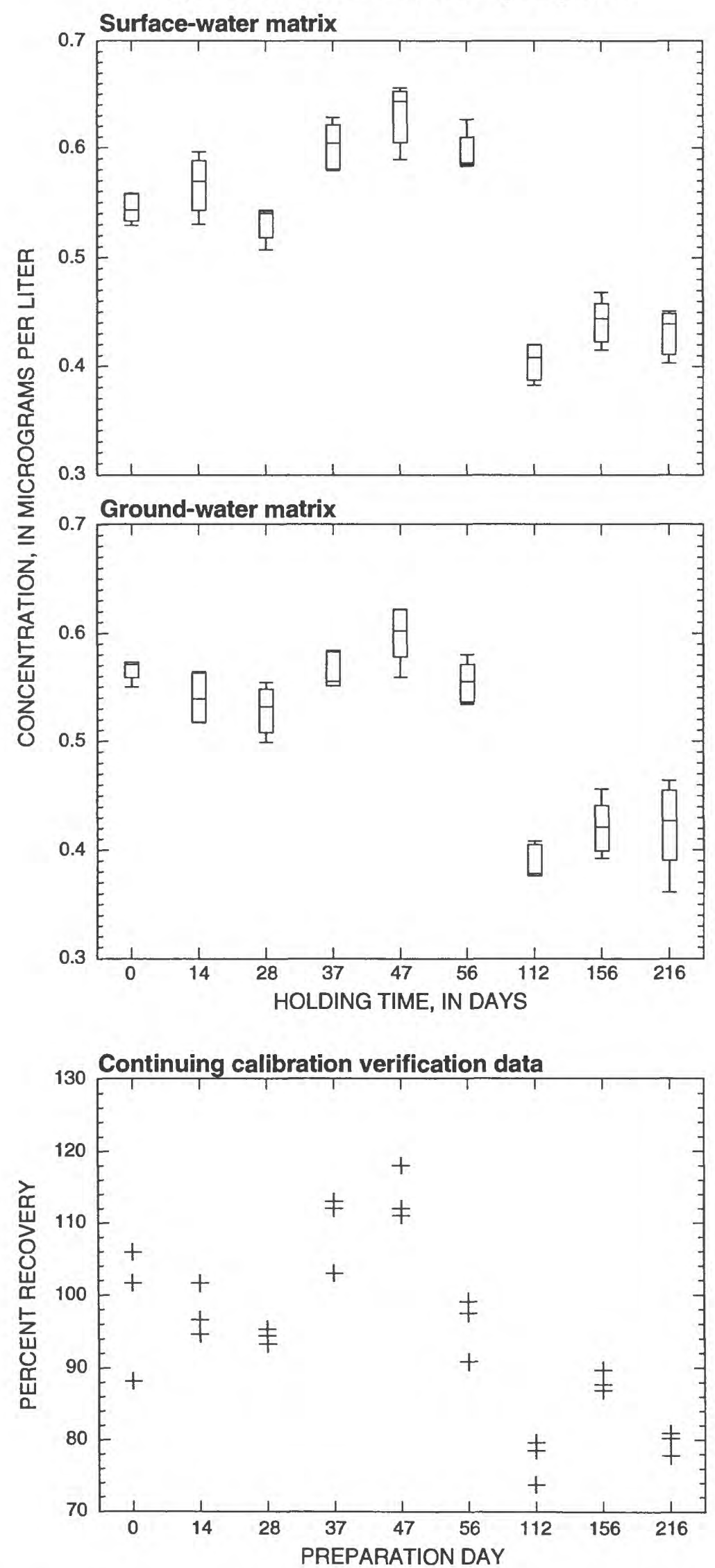


\section{Dibromochloromethane}
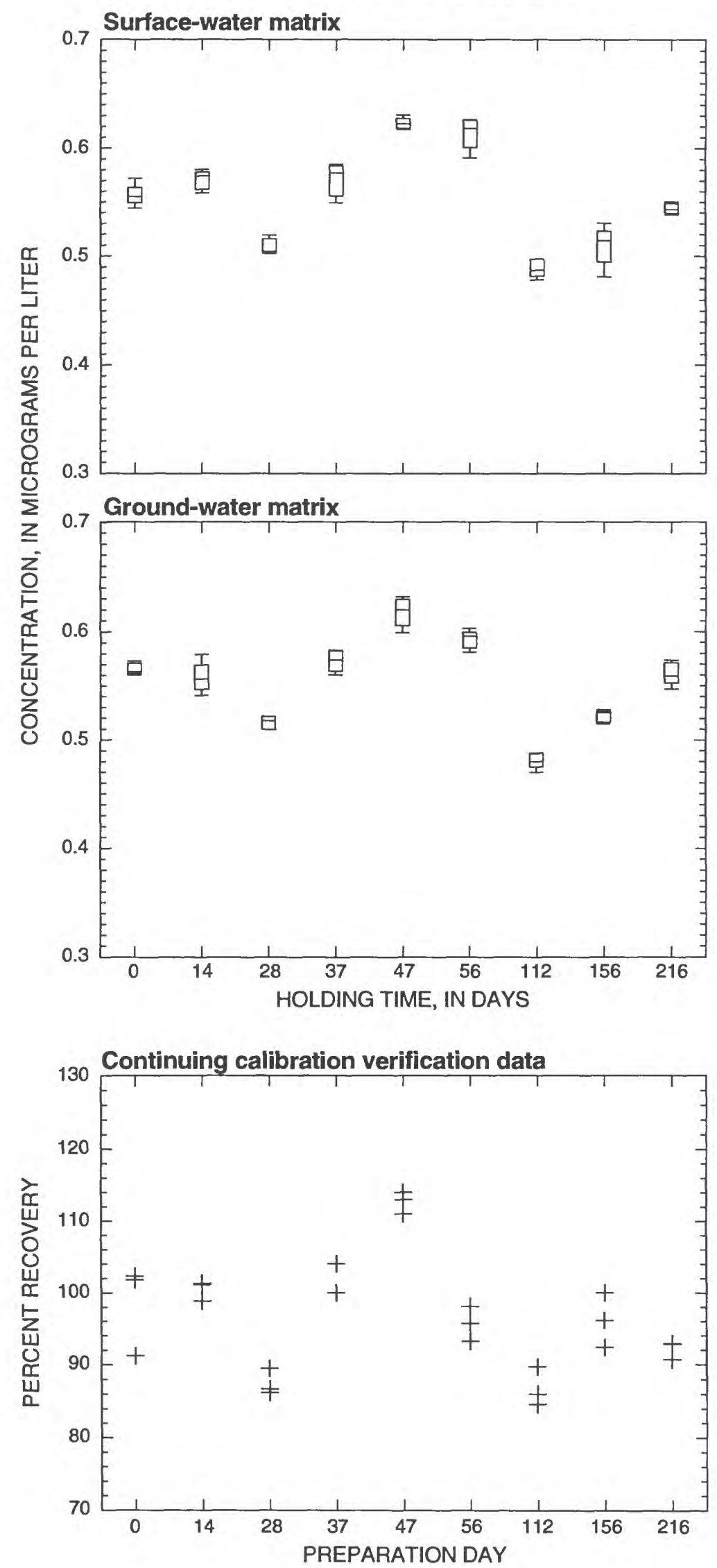

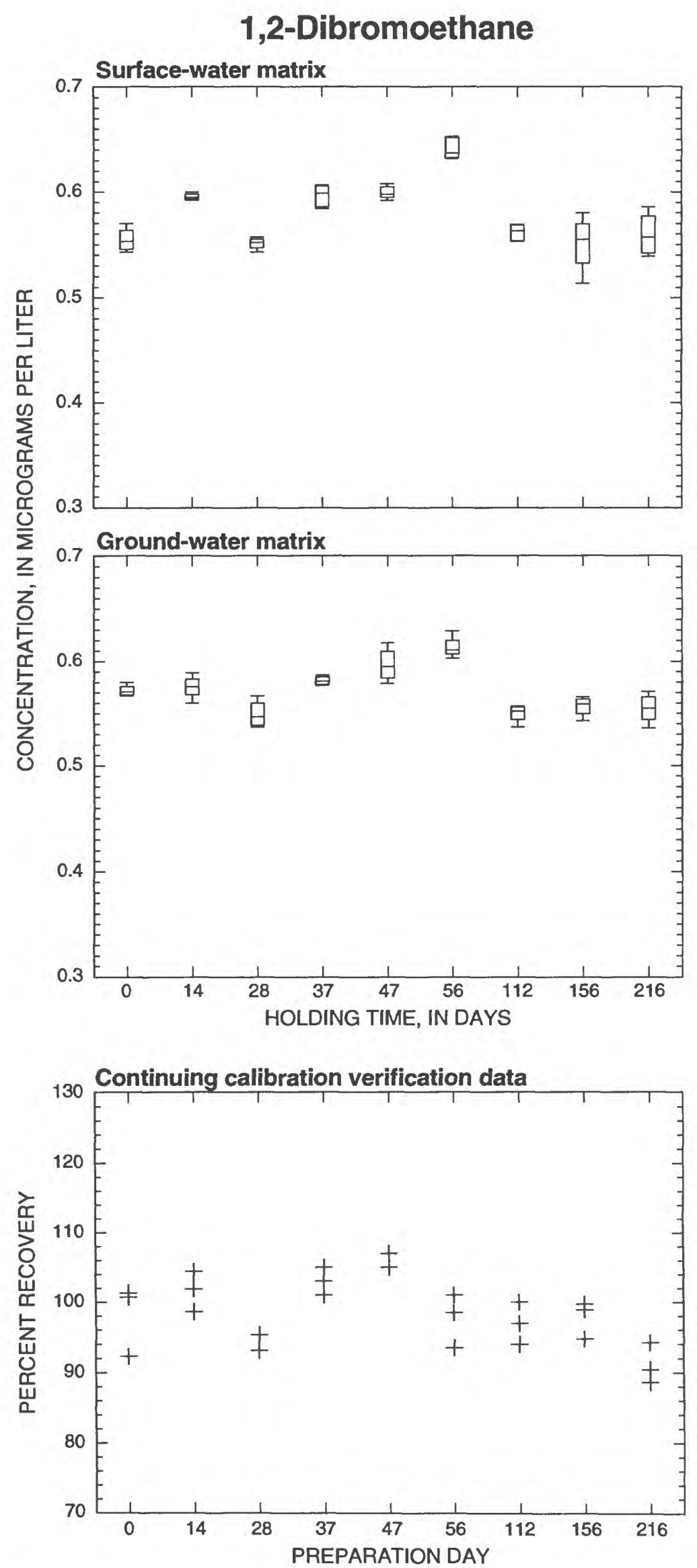
1,2-Dichlorobenzene
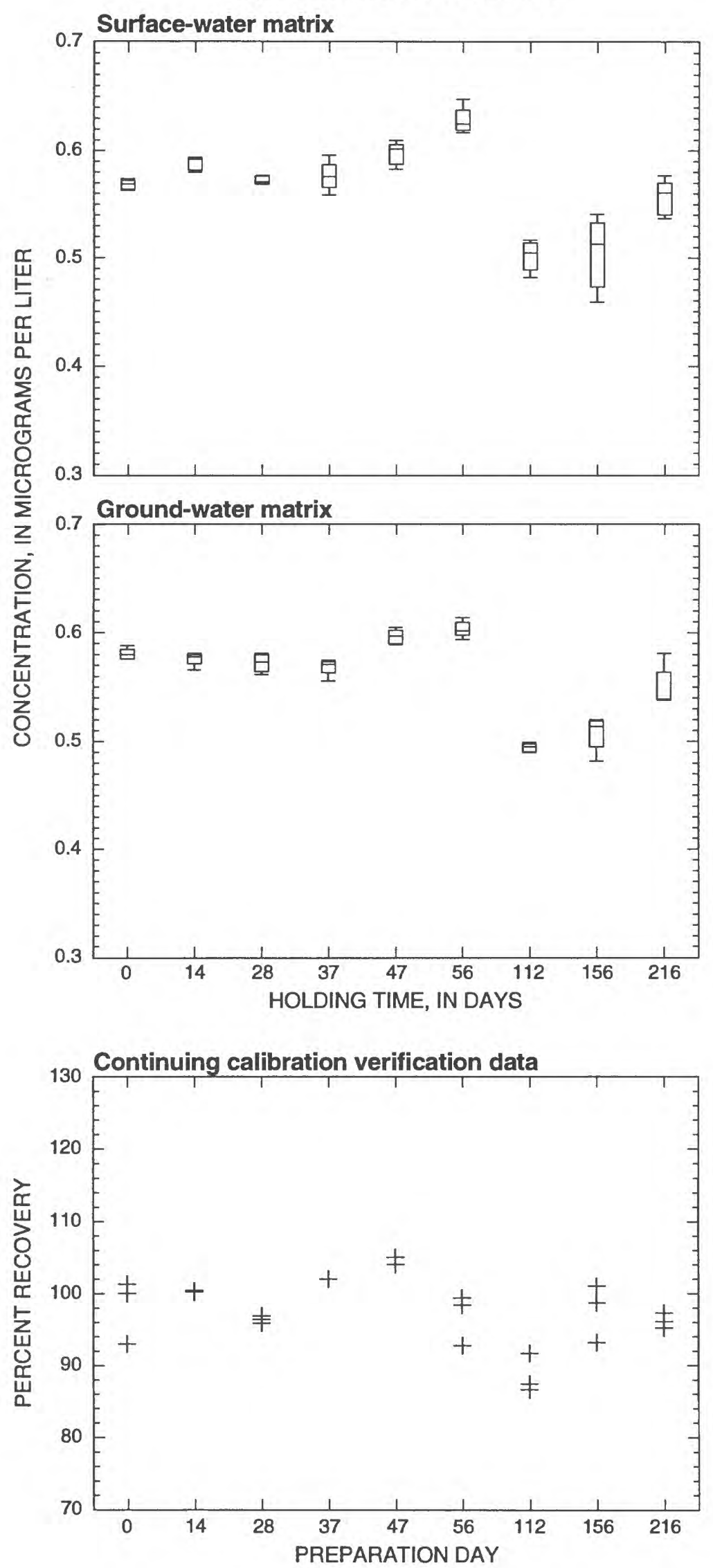


\section{1,3-Dichlorobenzene}
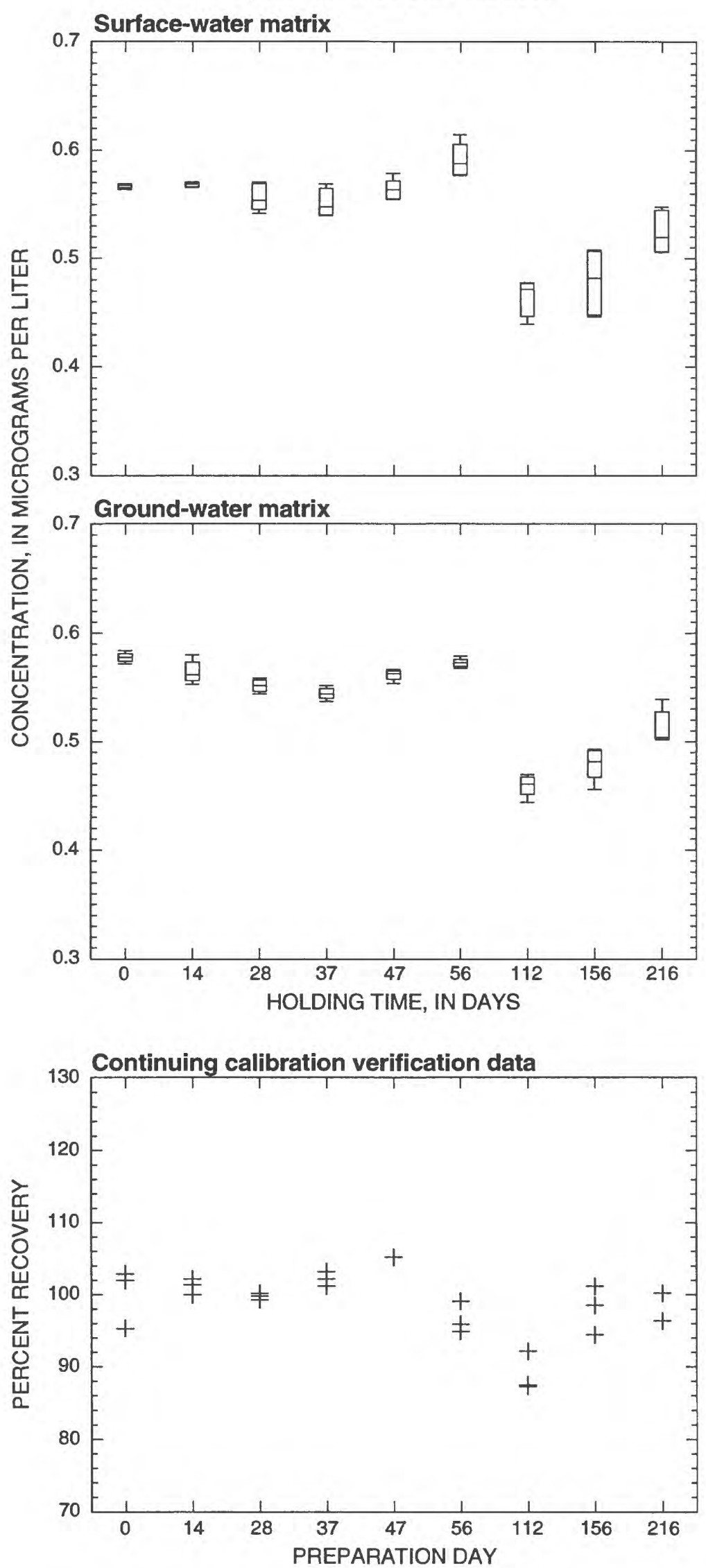

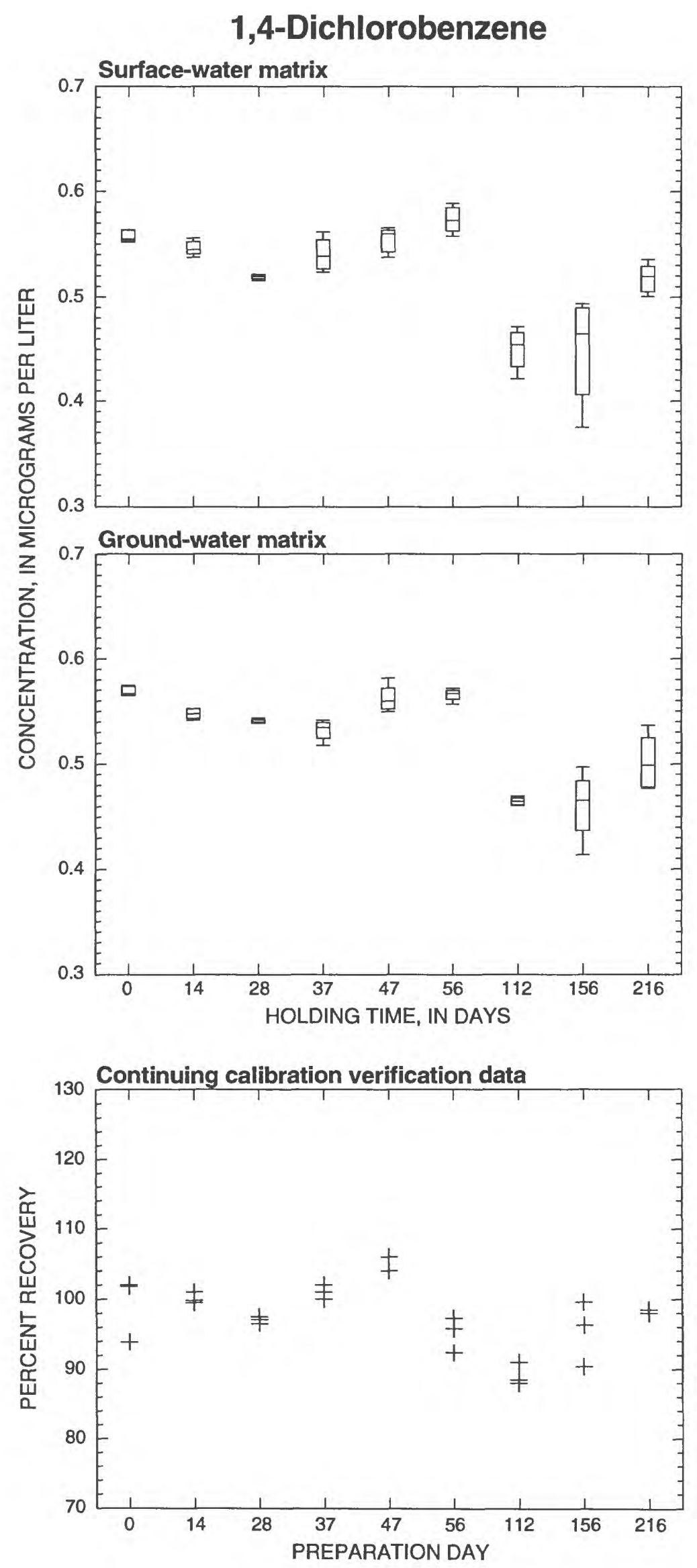


\section{Dichlorodifluoromethane}
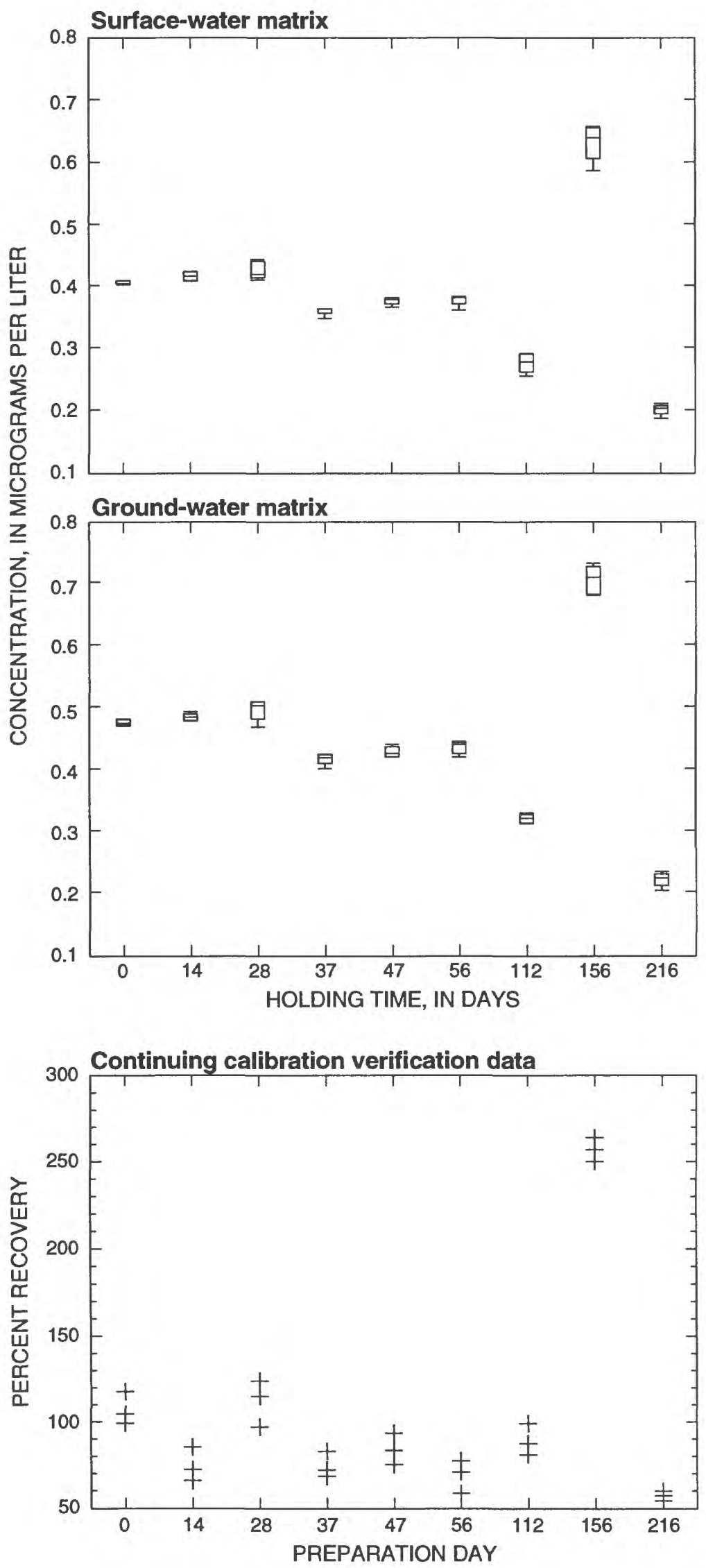
1,1-Dichloroethane
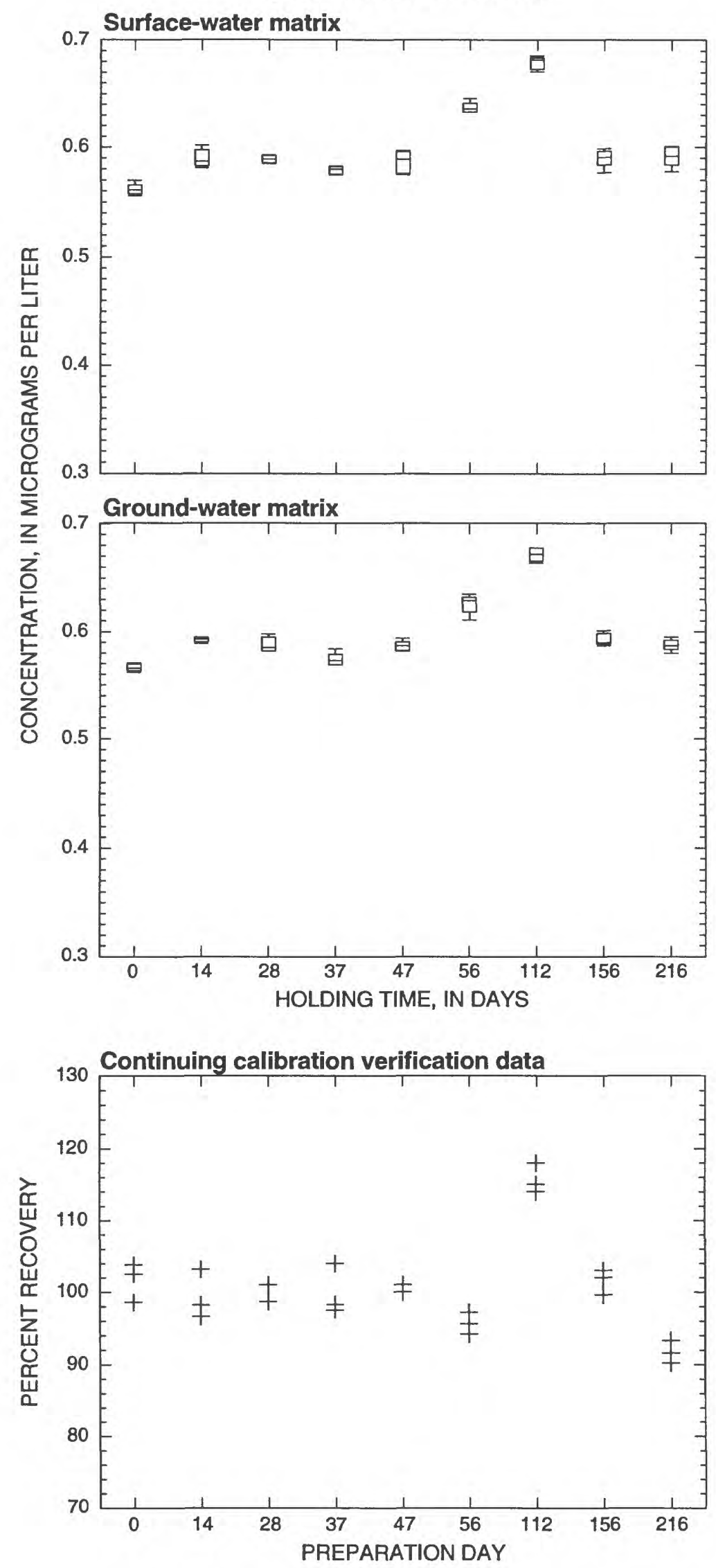
1,2-Dichloroethane
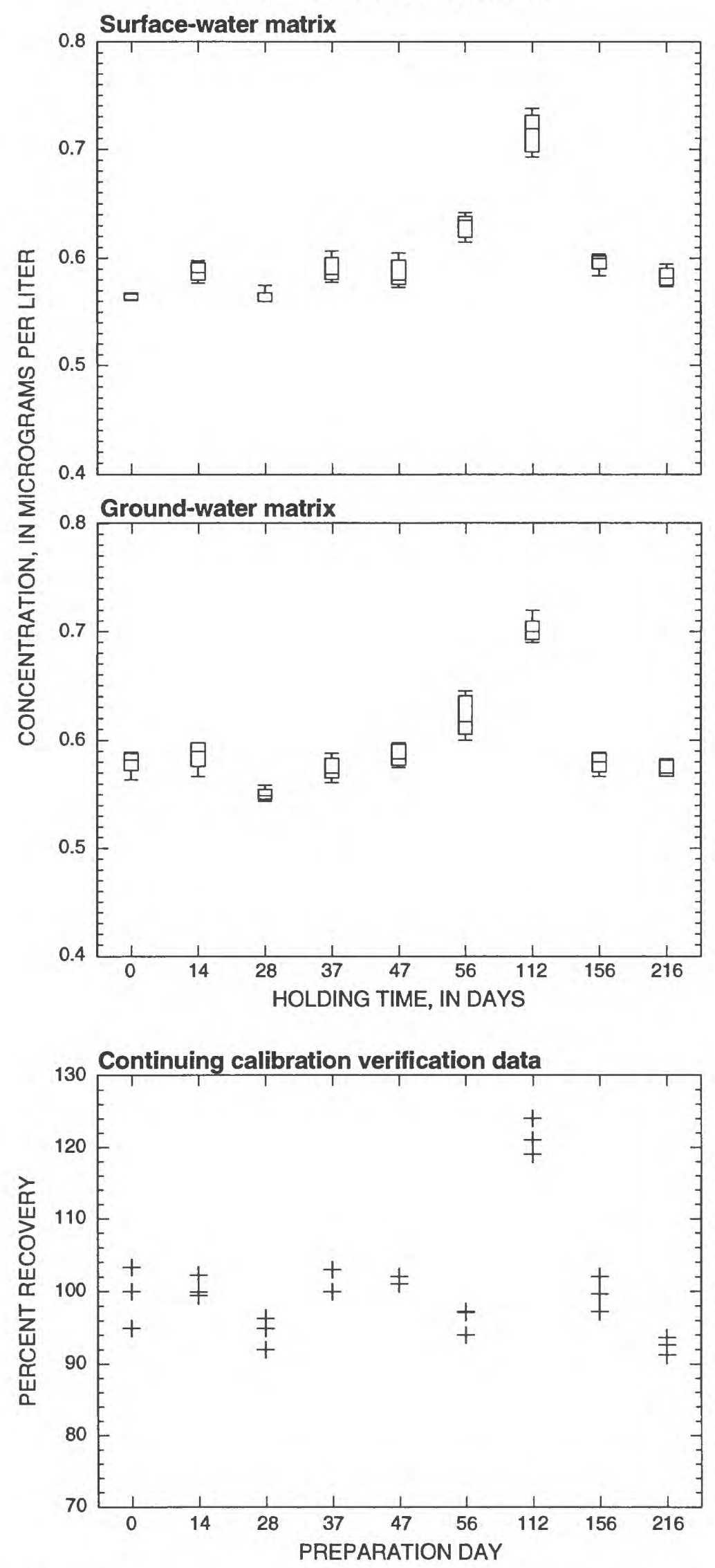


\section{1,1-Dichloroethene}
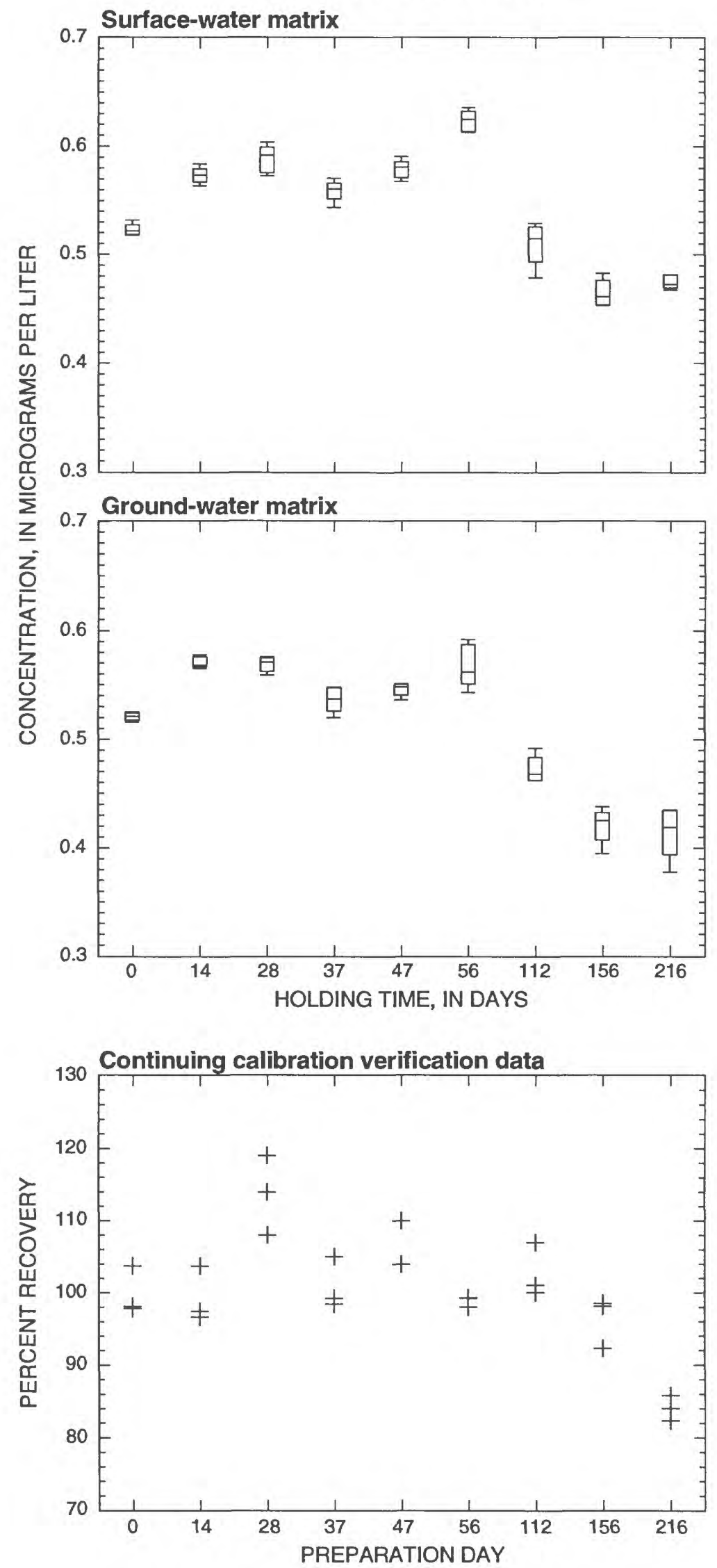
cis-1,2-Dichloroethene
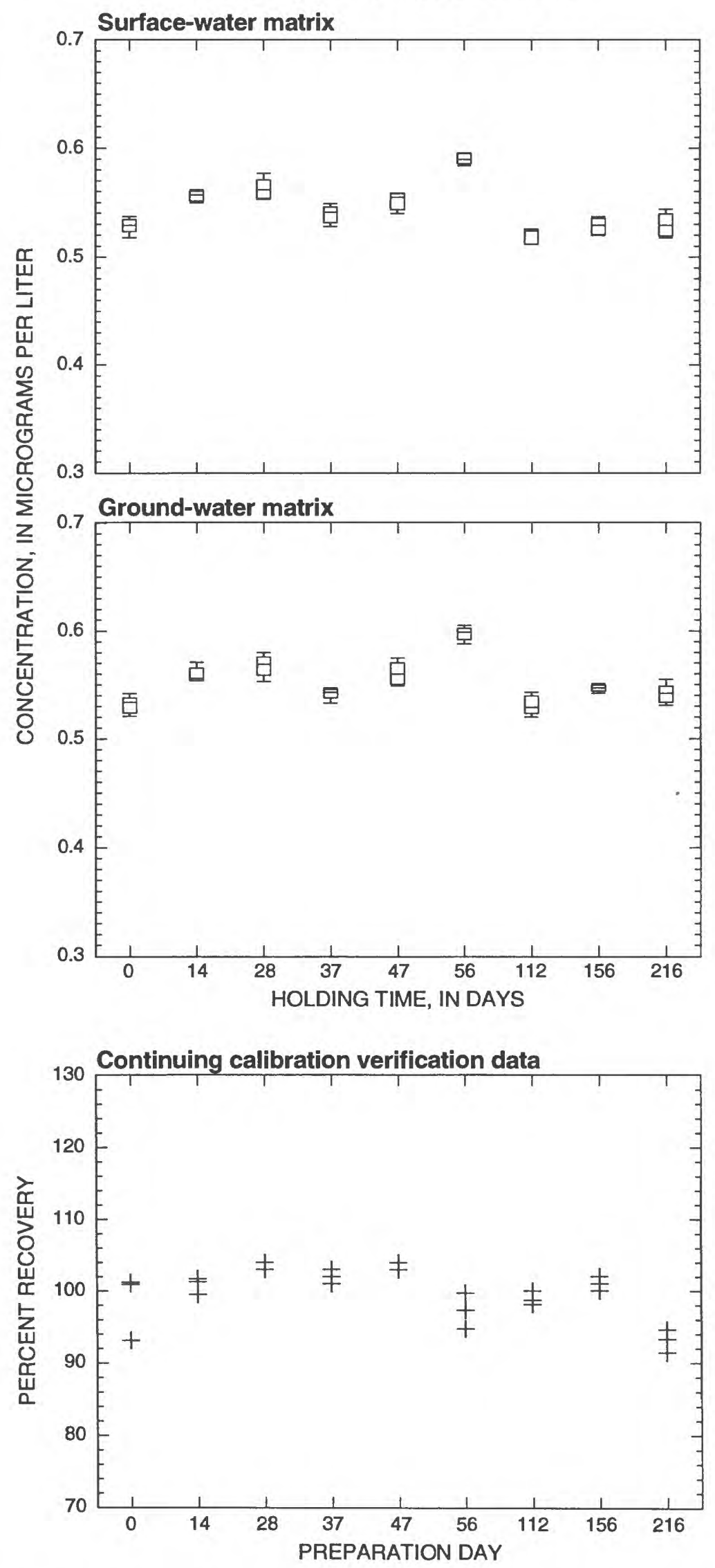
trans-1,2-Dichloroethene
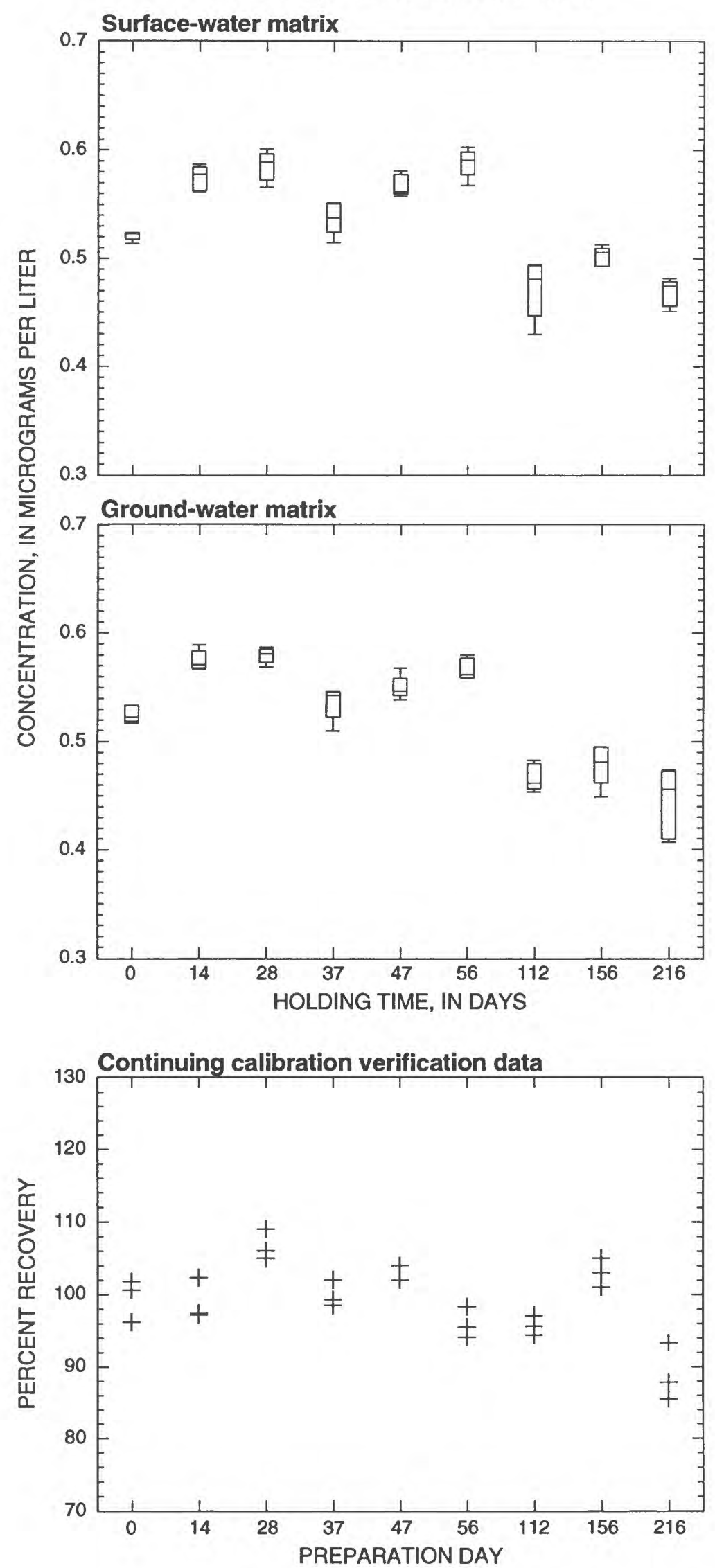


\section{Dichloromethane}
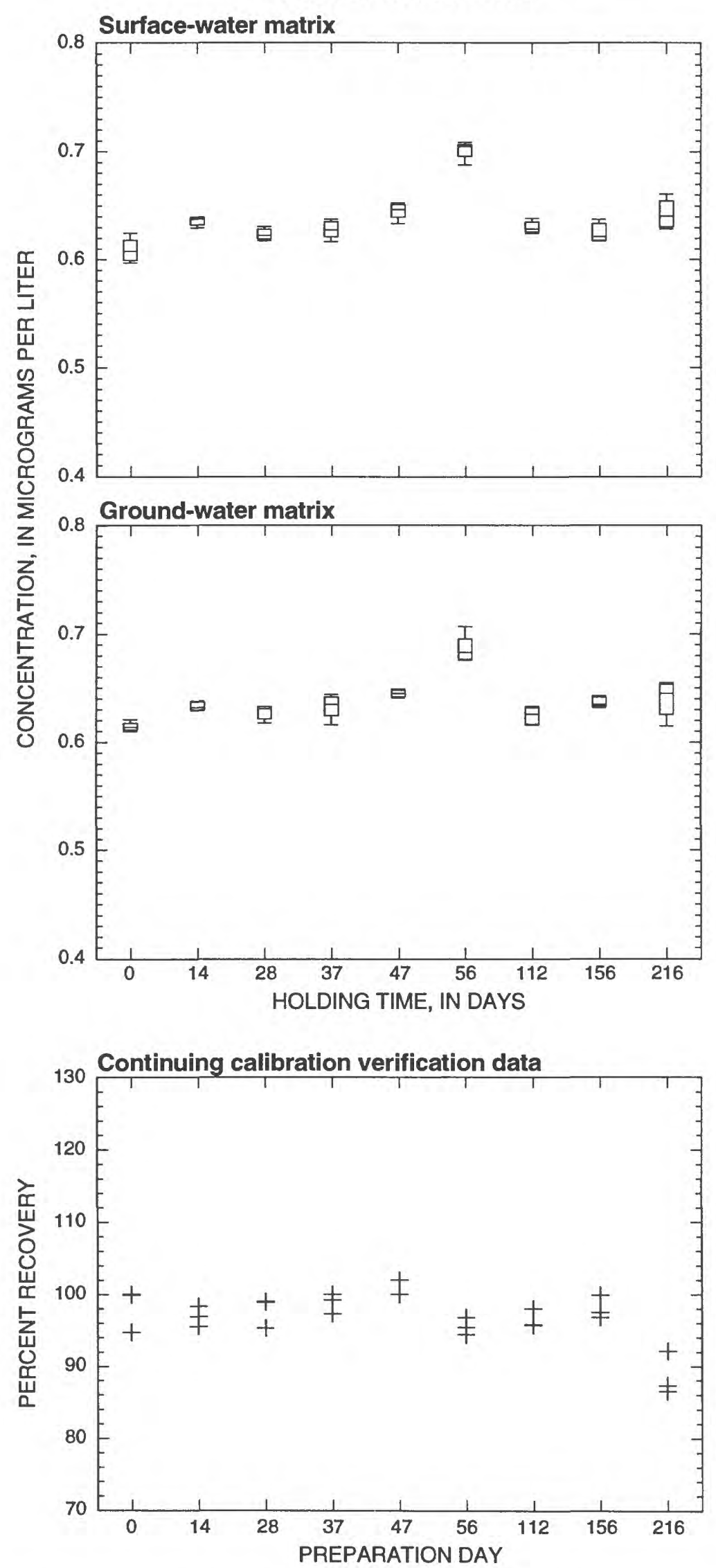
1,2-Dichloropropane
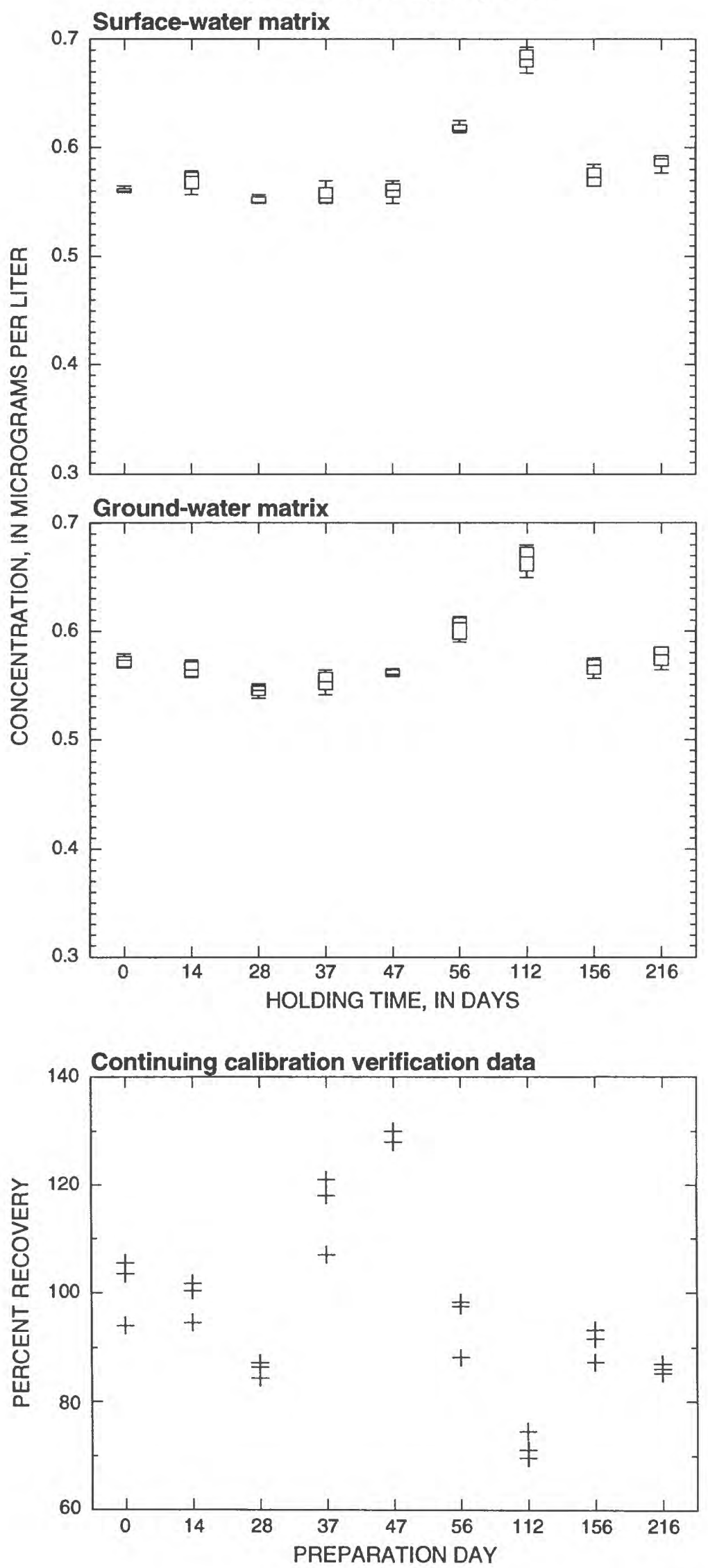
cis-1,3-Dichloropropene
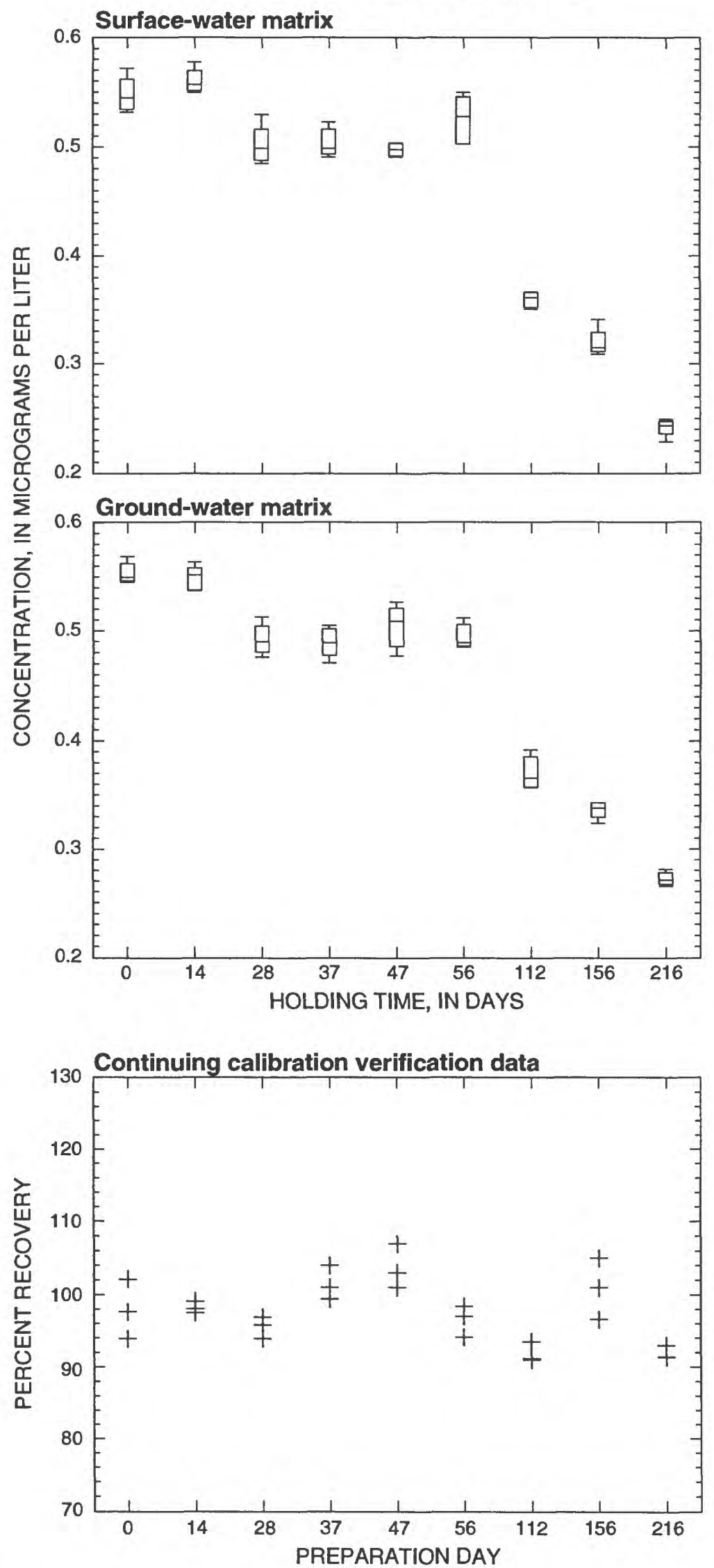

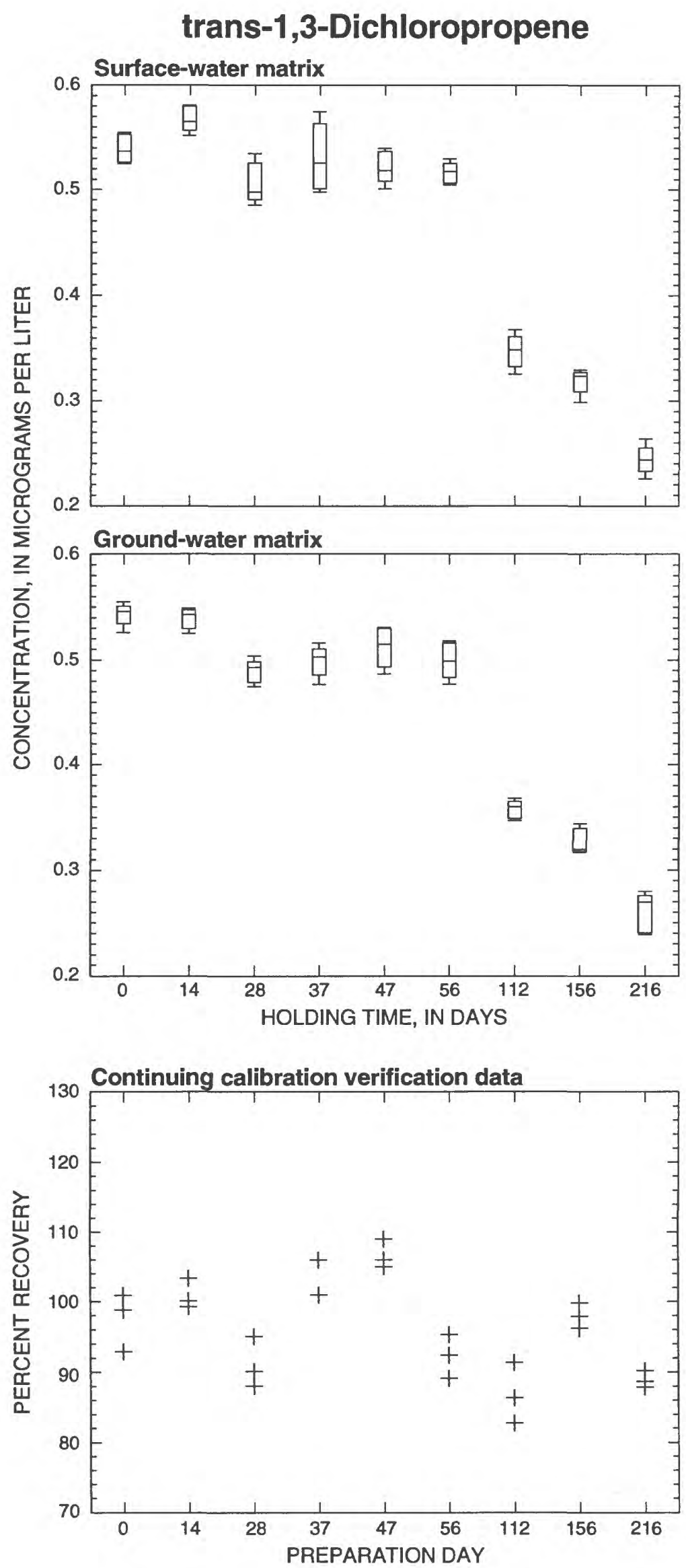
1,2-Dimethylbenzene
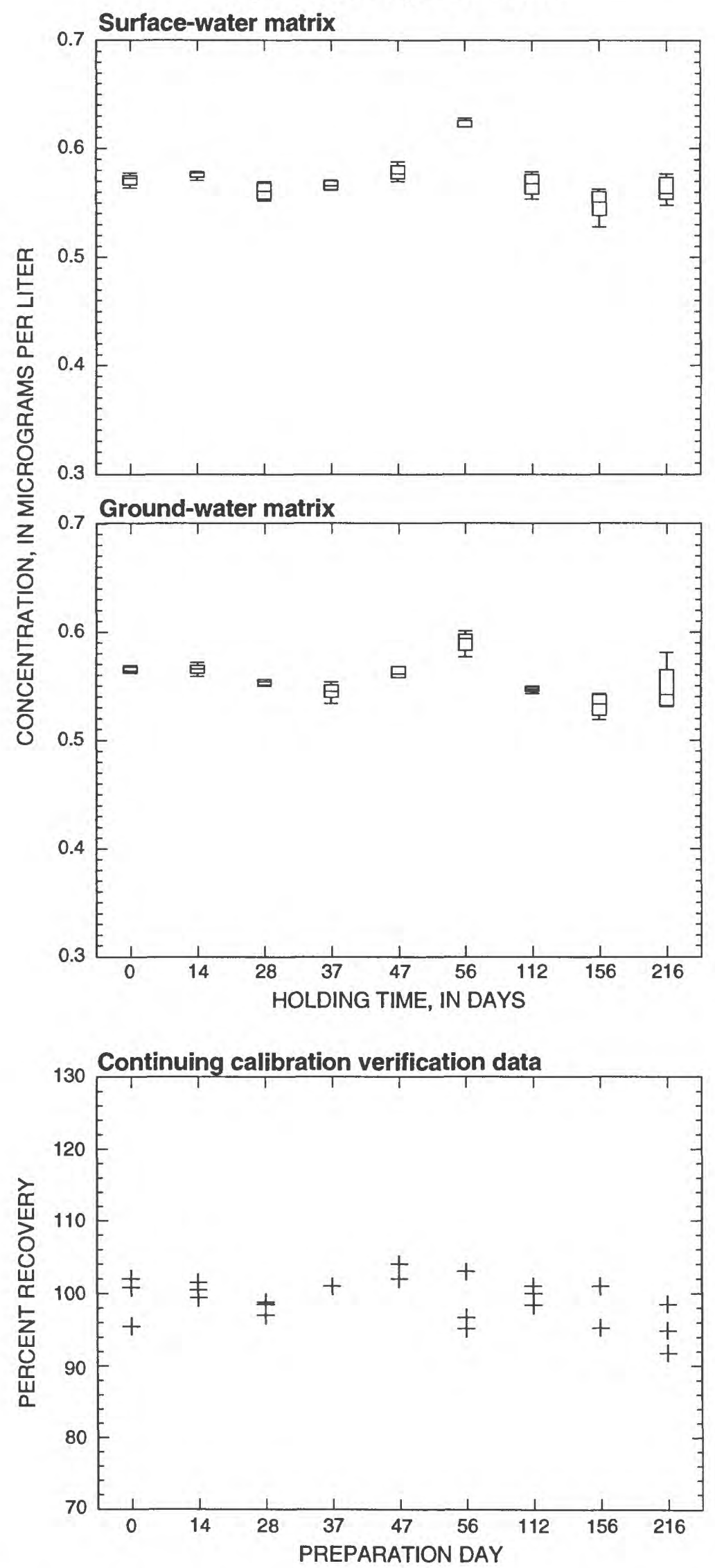
1,3- and 1,4-Dimethylbenzene
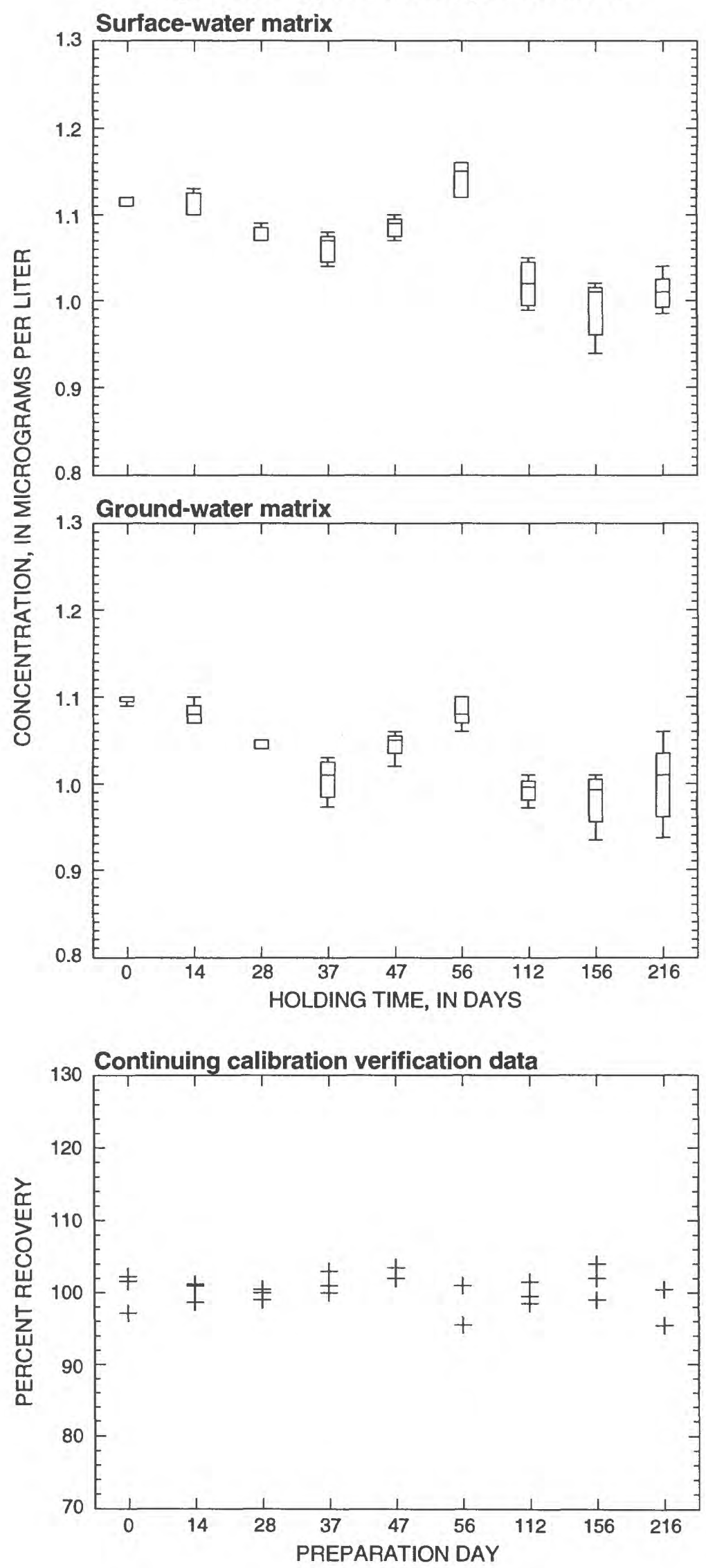


\section{Ethenylbenzene}
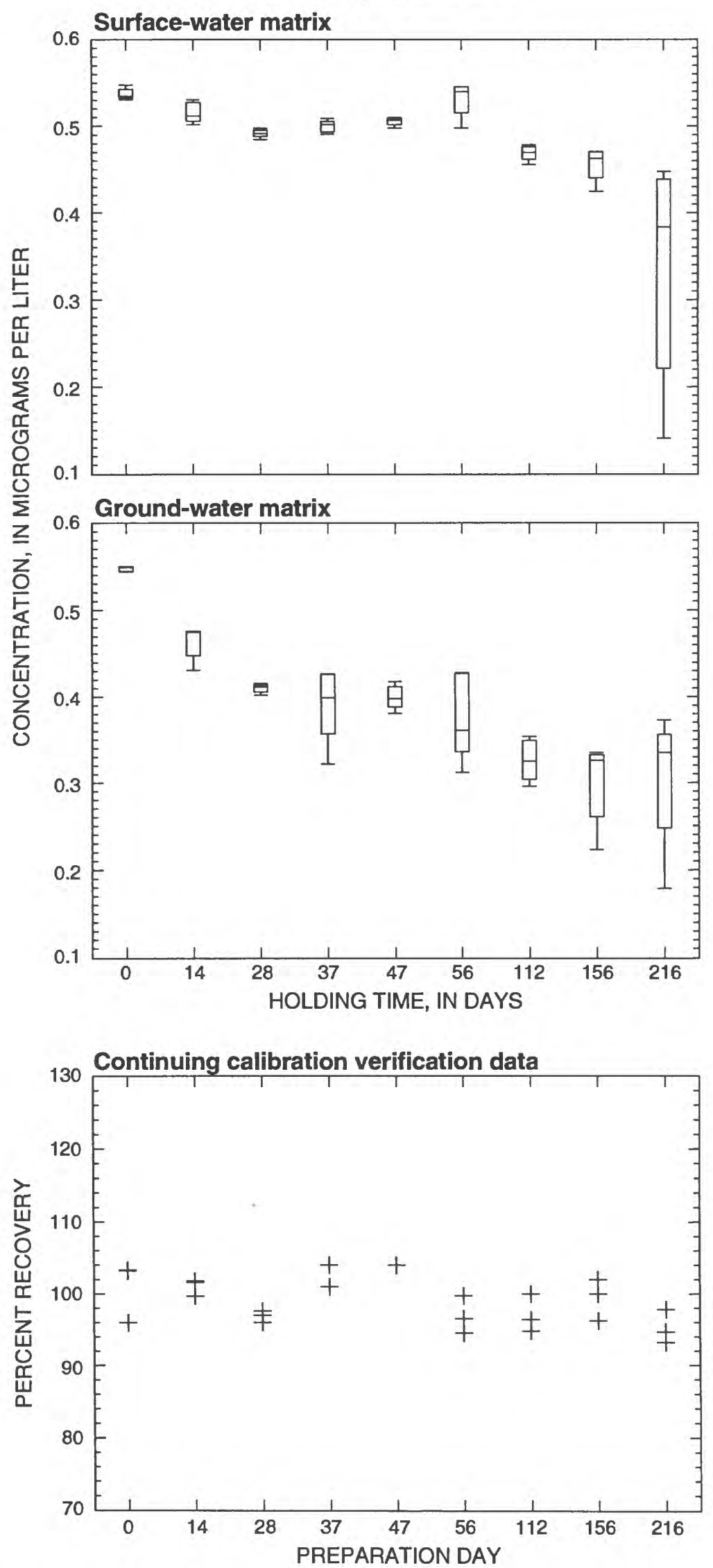

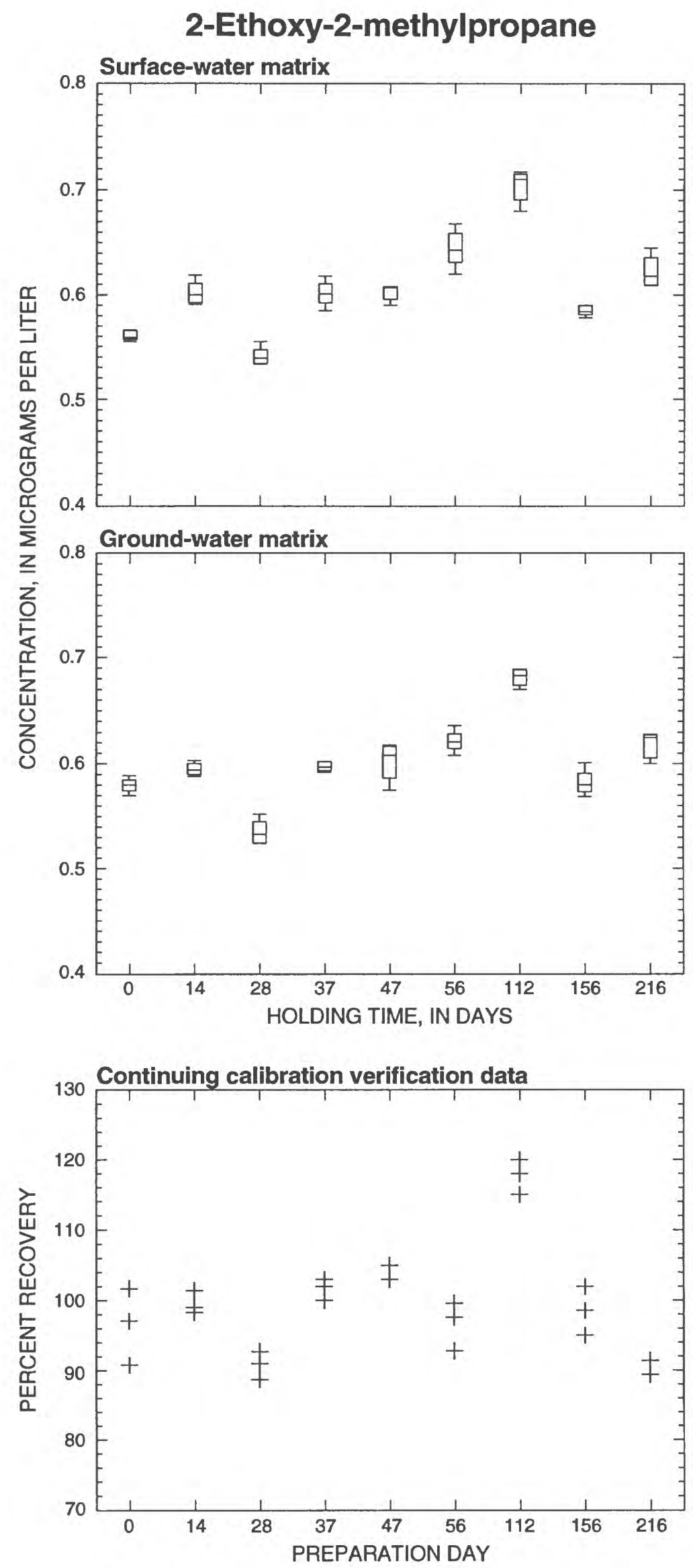
Ethylbenzene
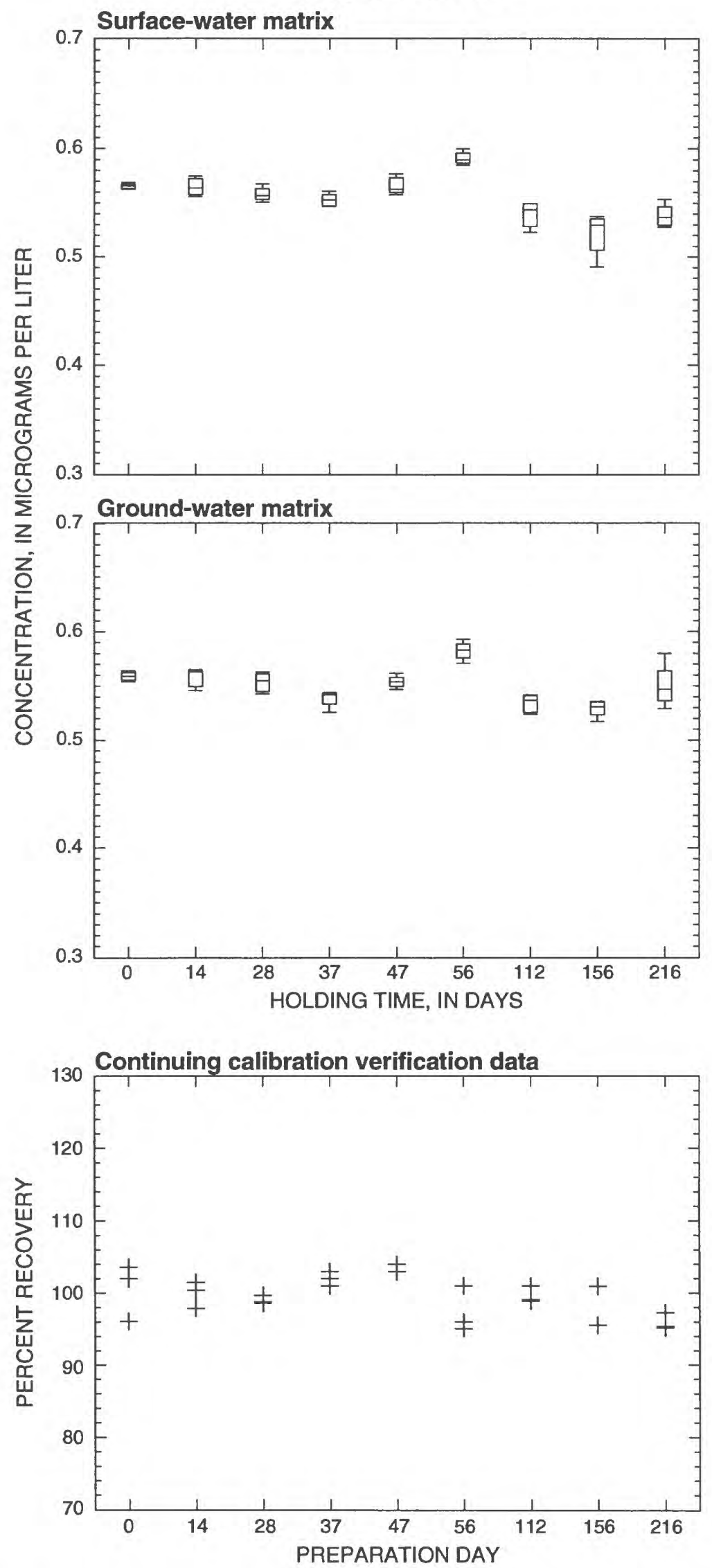
1,1,2,3,4,4-Hexachloro-1,3-butadiene
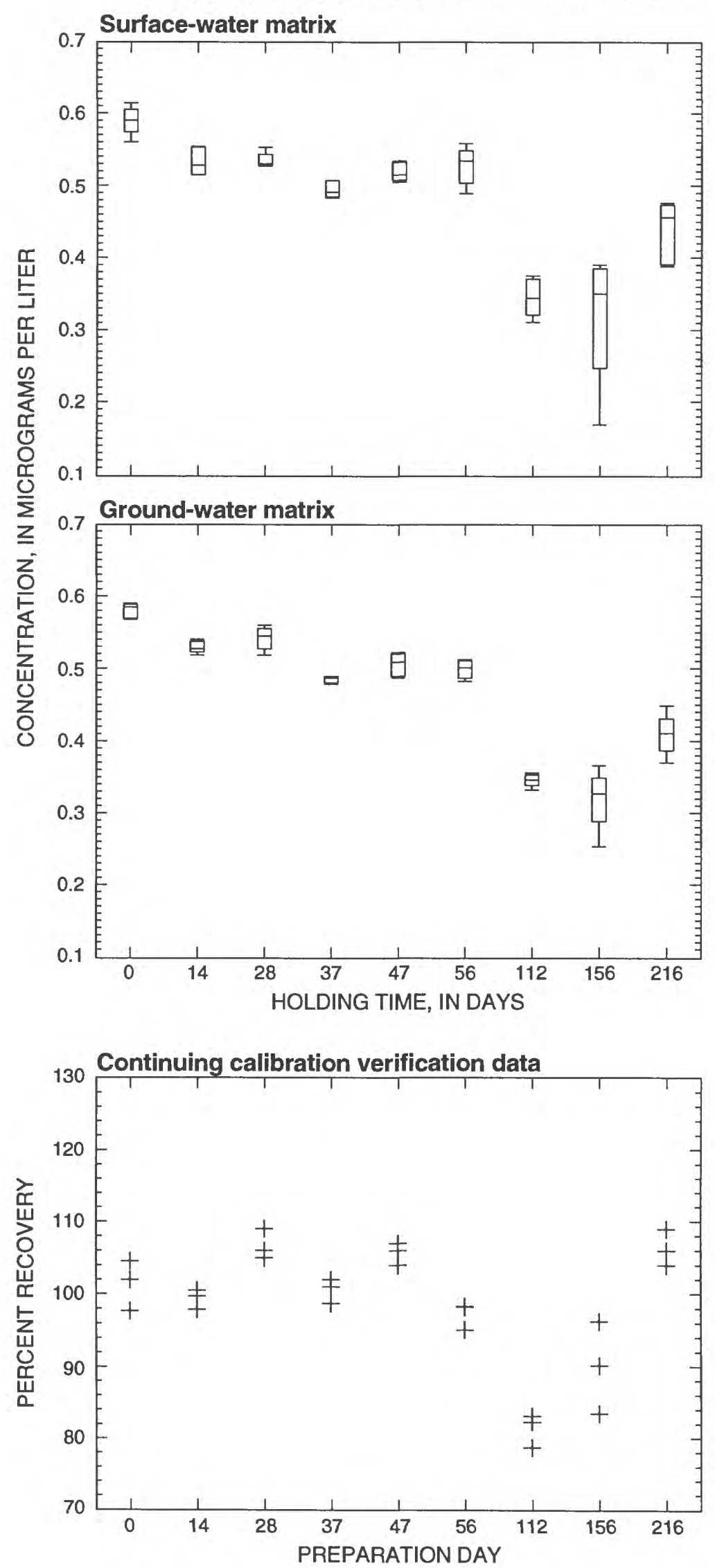
1,1,1,2,2,2-Hexachloroethane
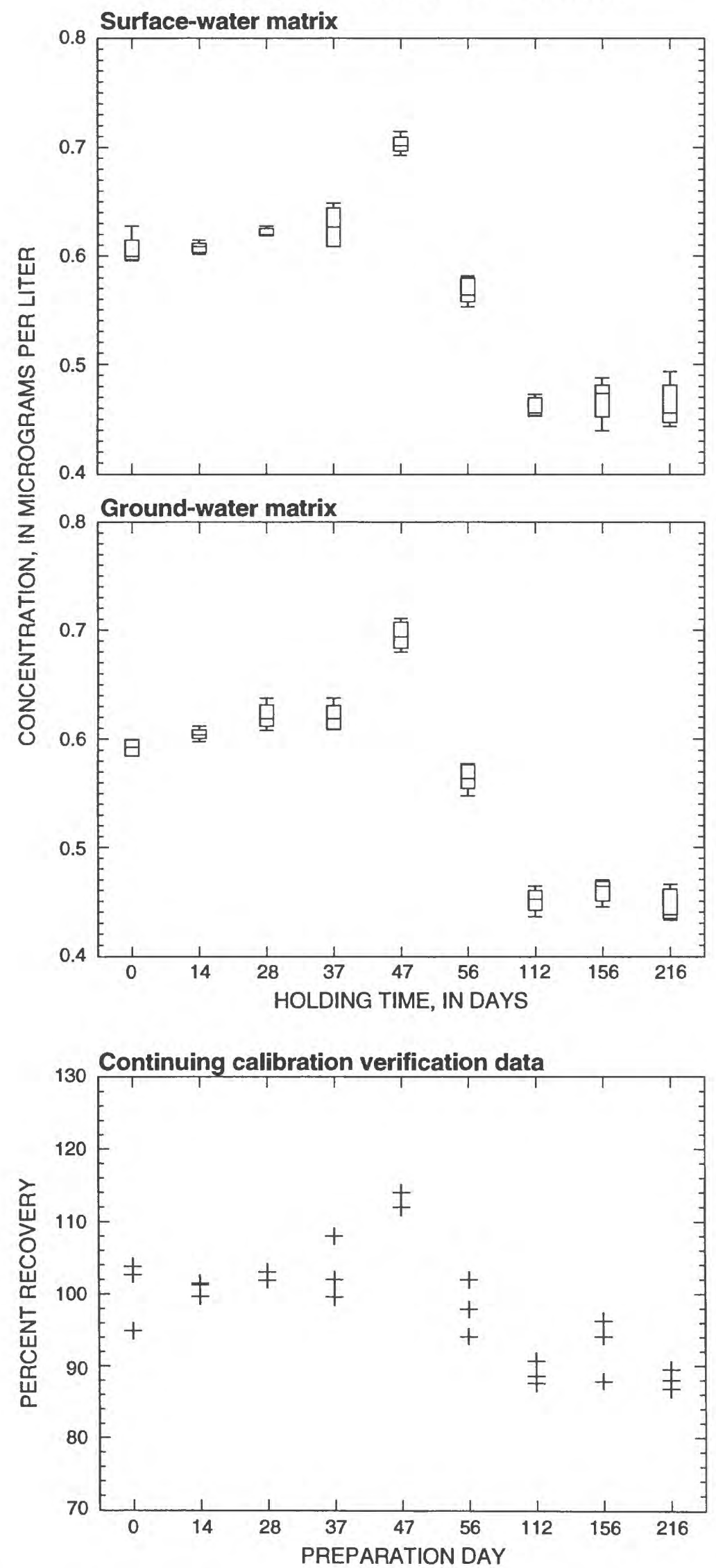

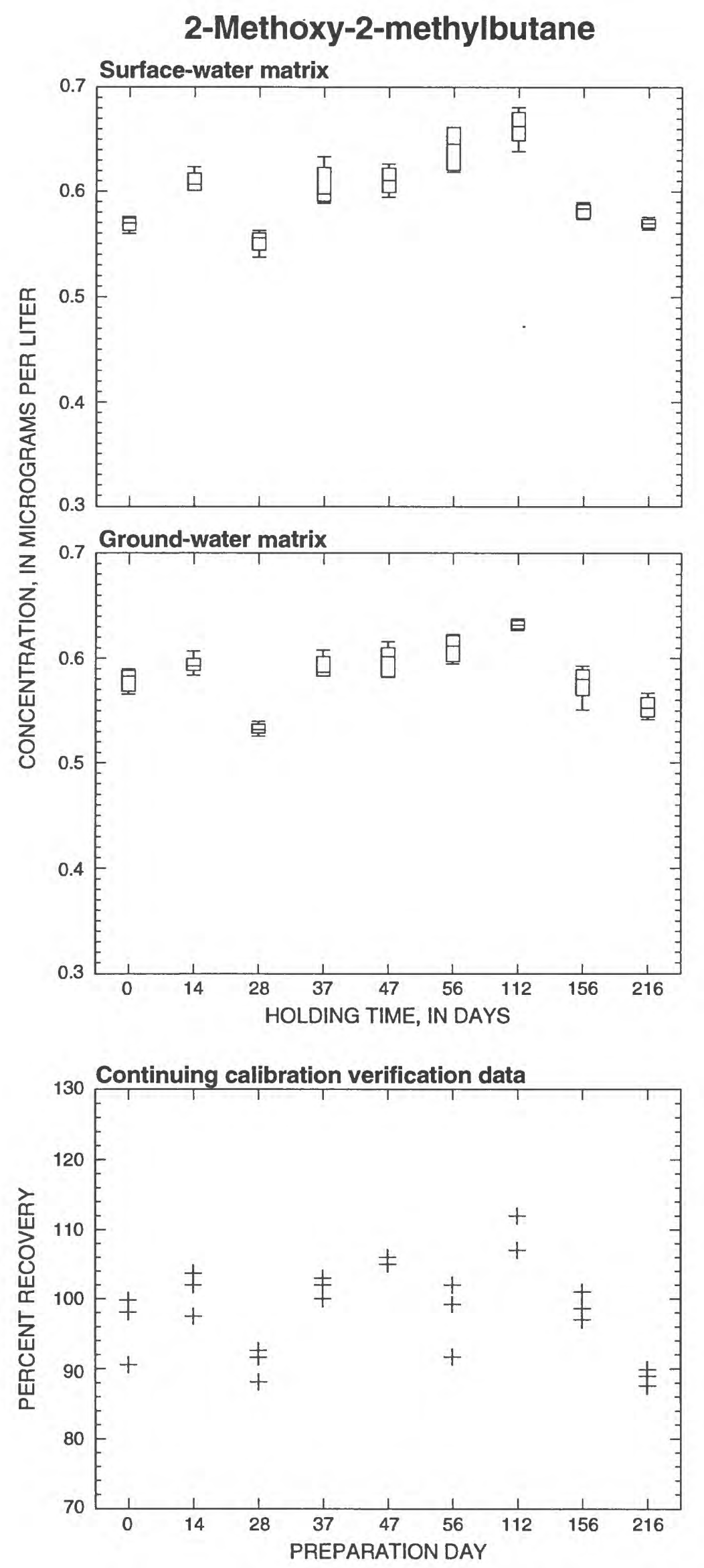
2-Methoxy-2-methylpropane
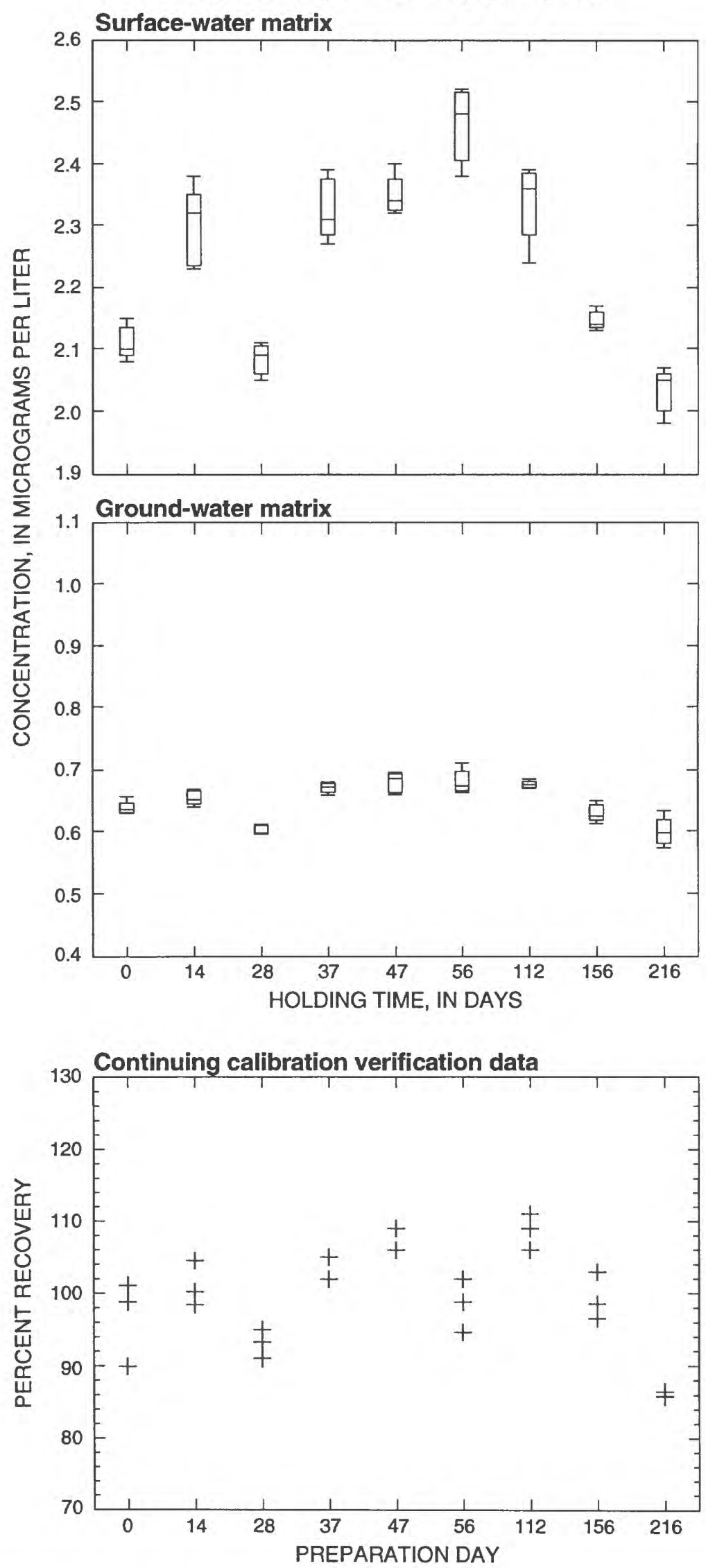

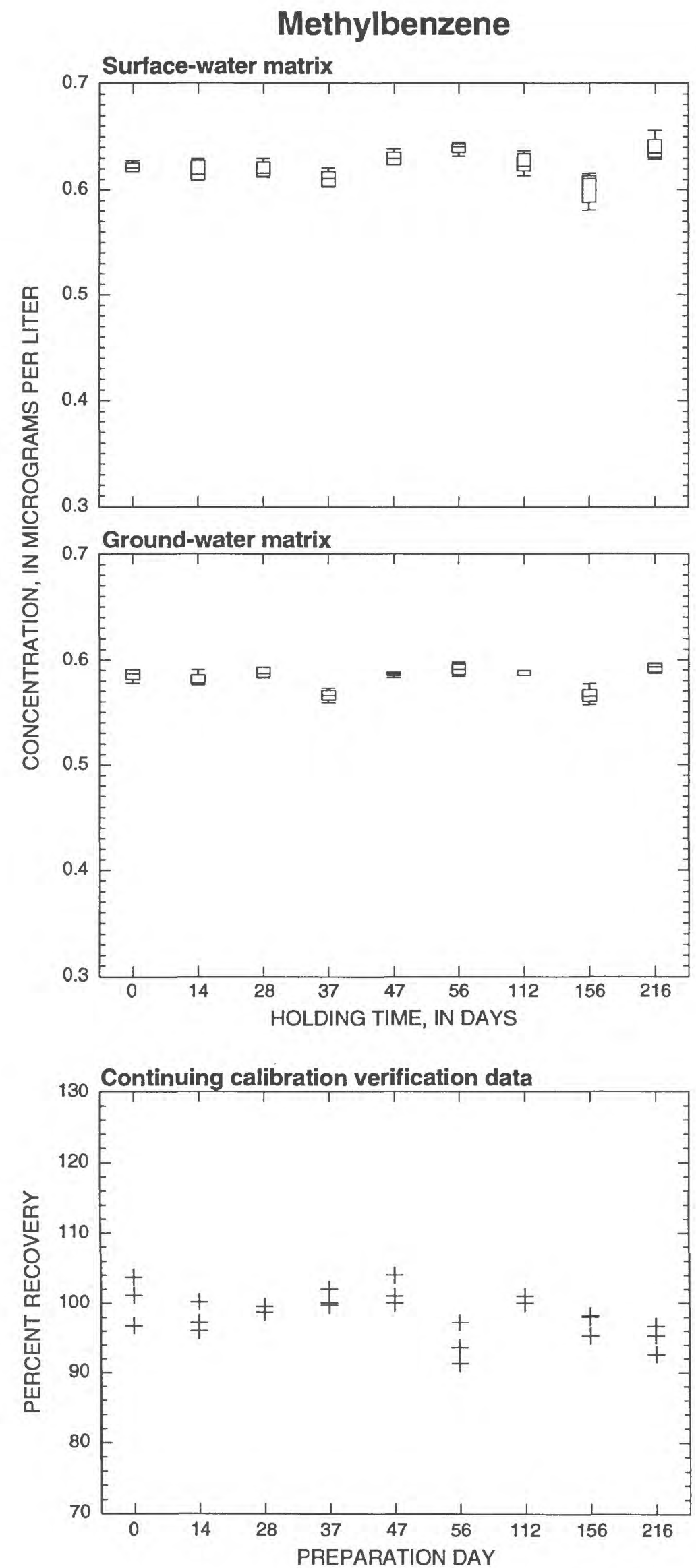
(1-Methylethyl)benzene
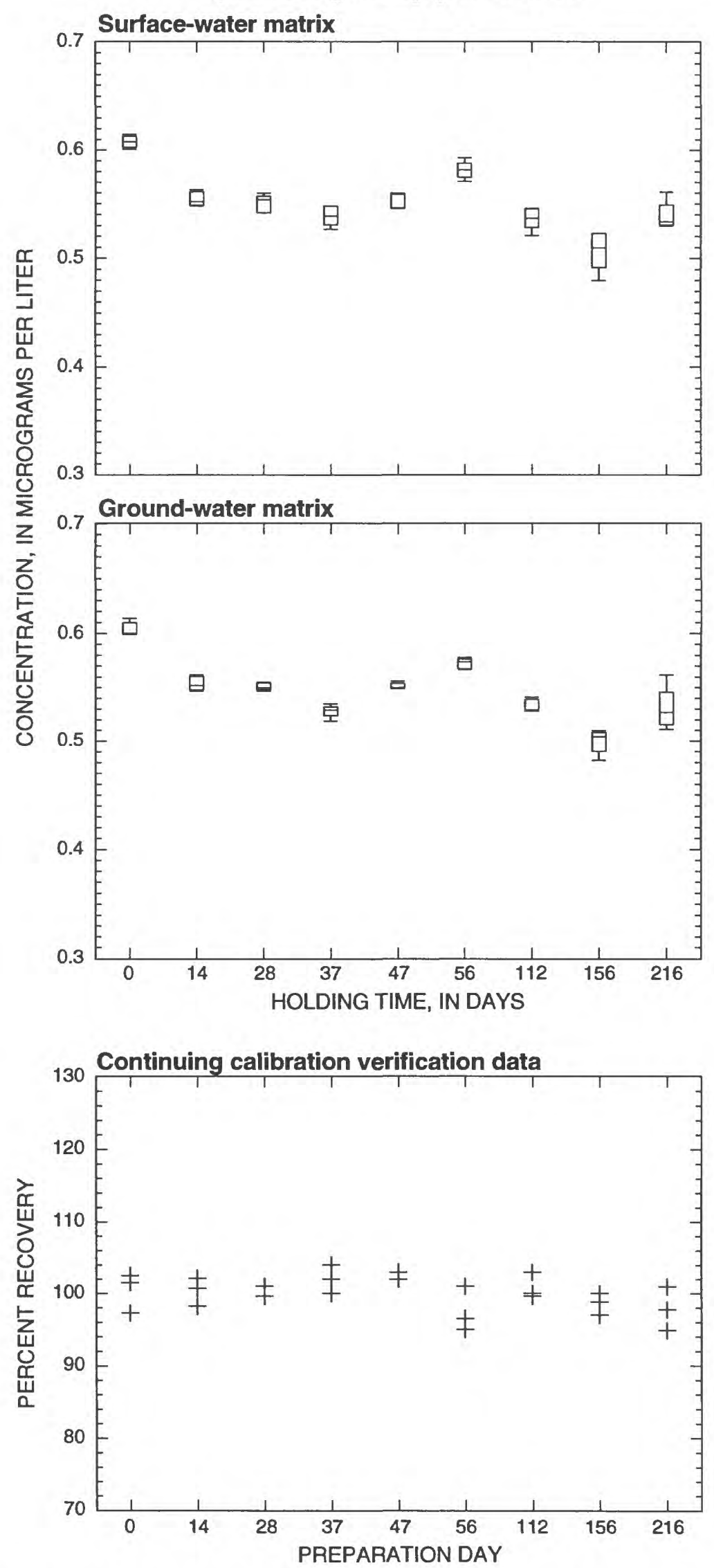
Naphthalene
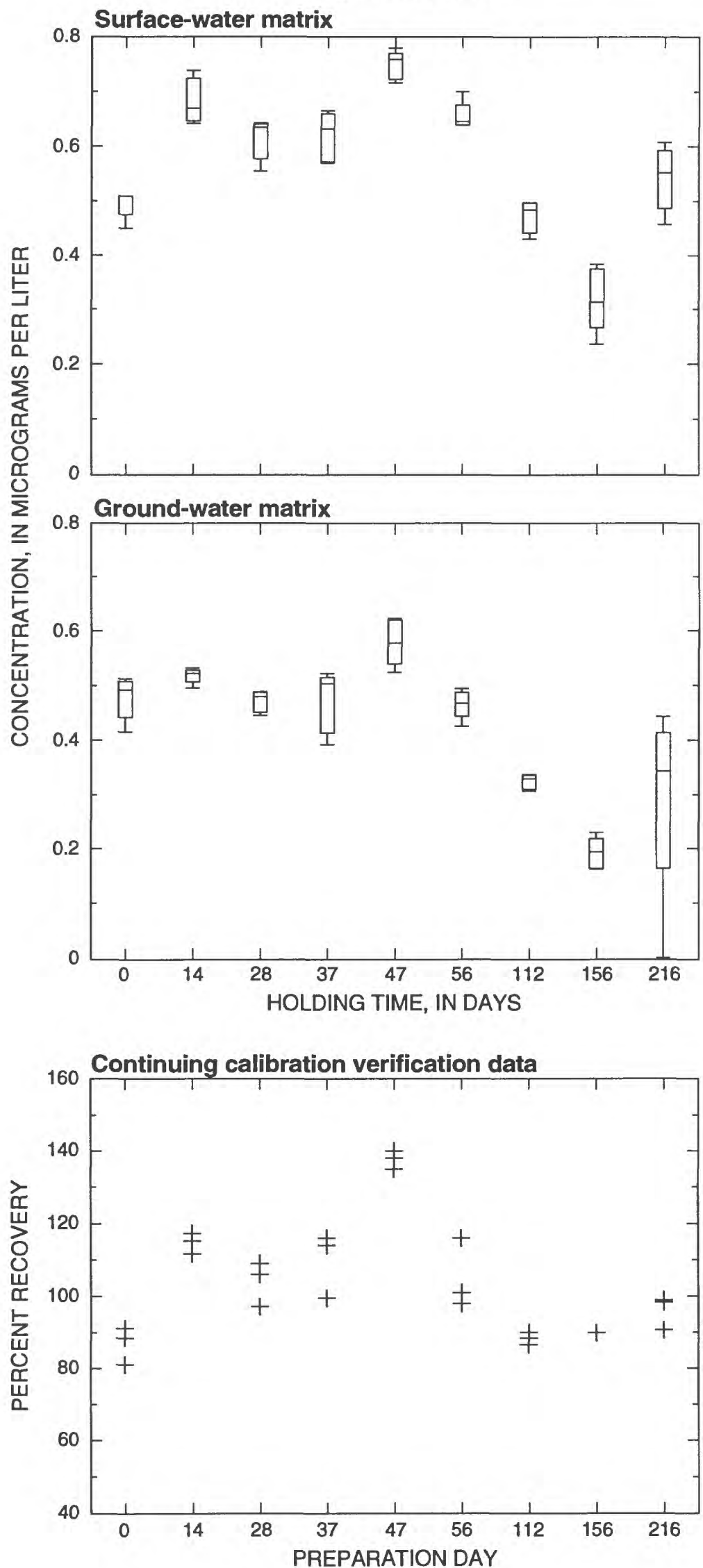
2,2'-Oxybis[propane]
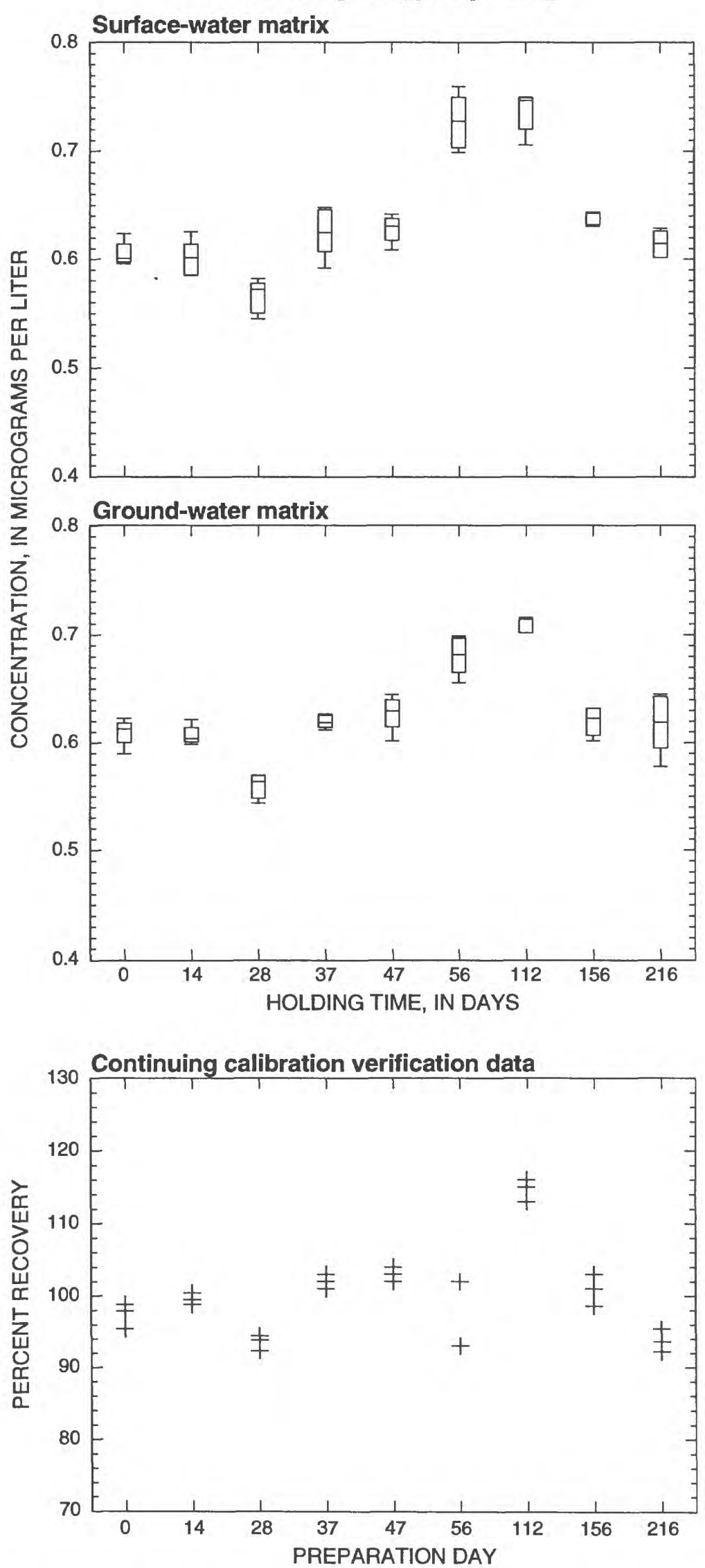
2-Propenal
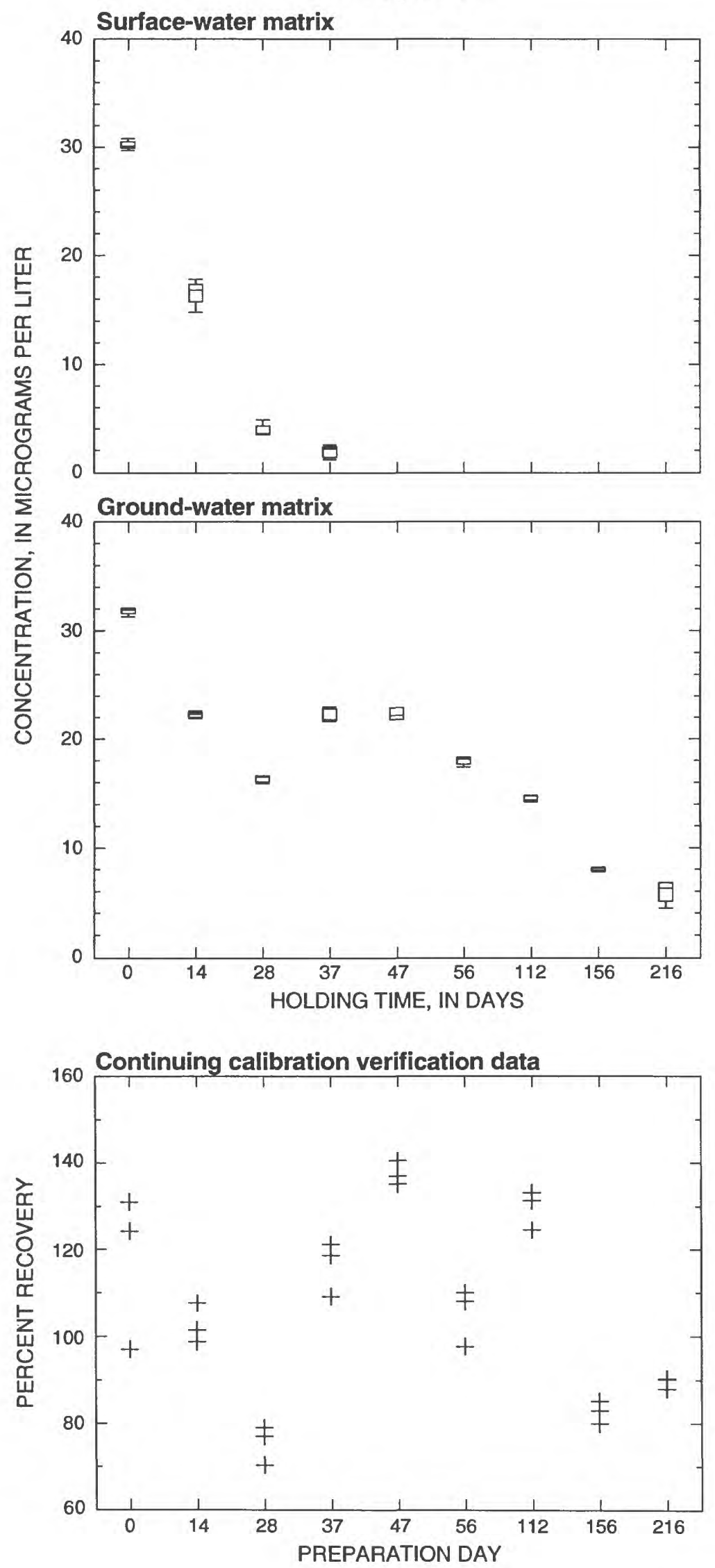


\section{2-Propenenitrile}
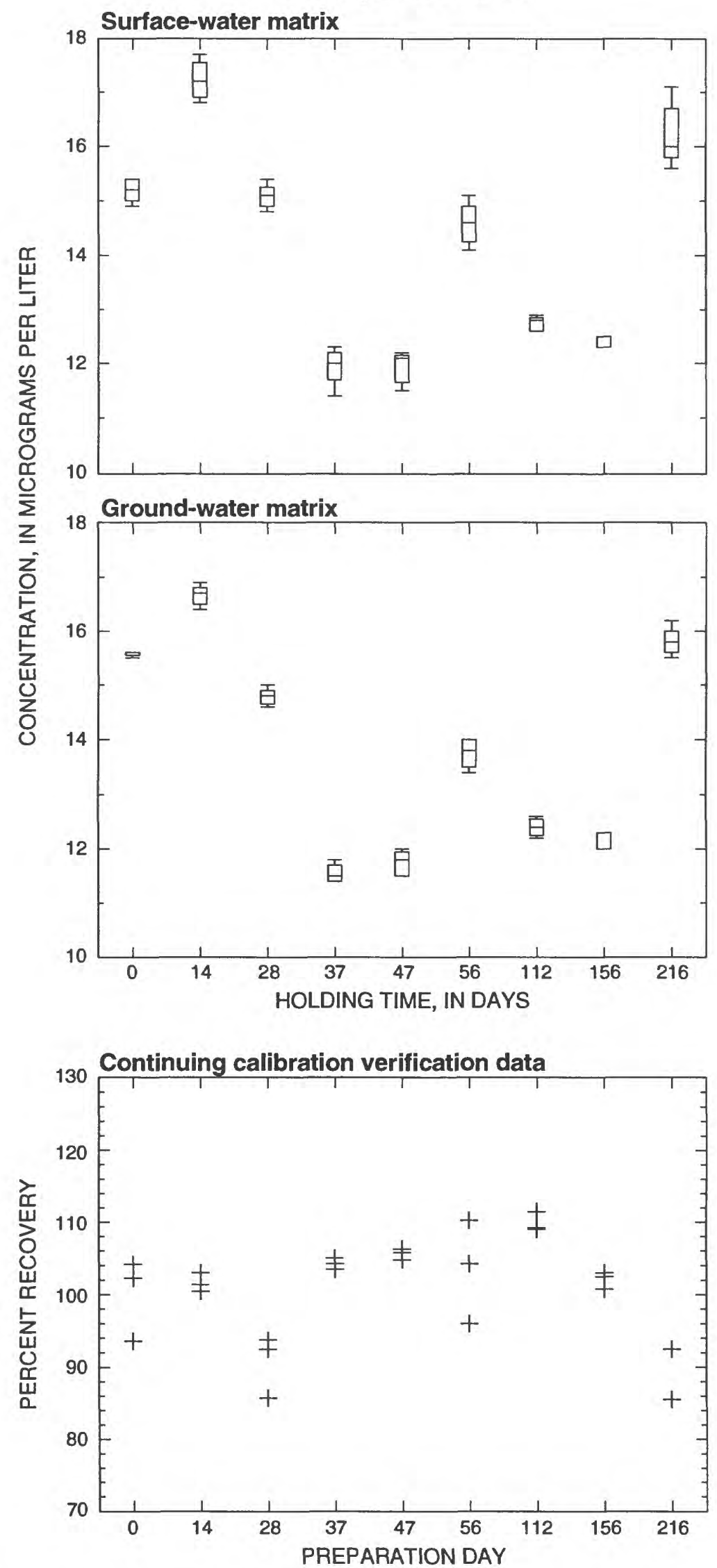
n-Propylbenzene
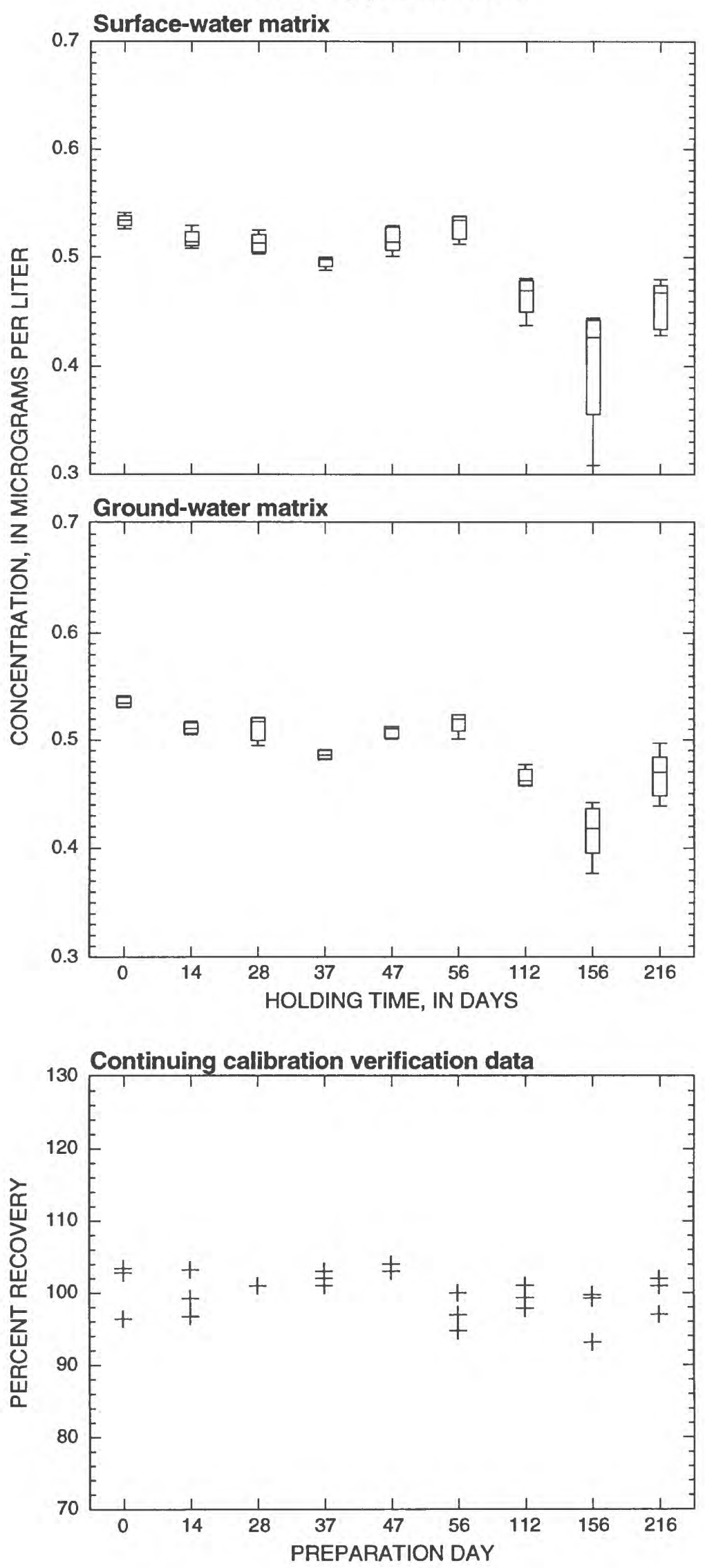
Tetrachloroethene
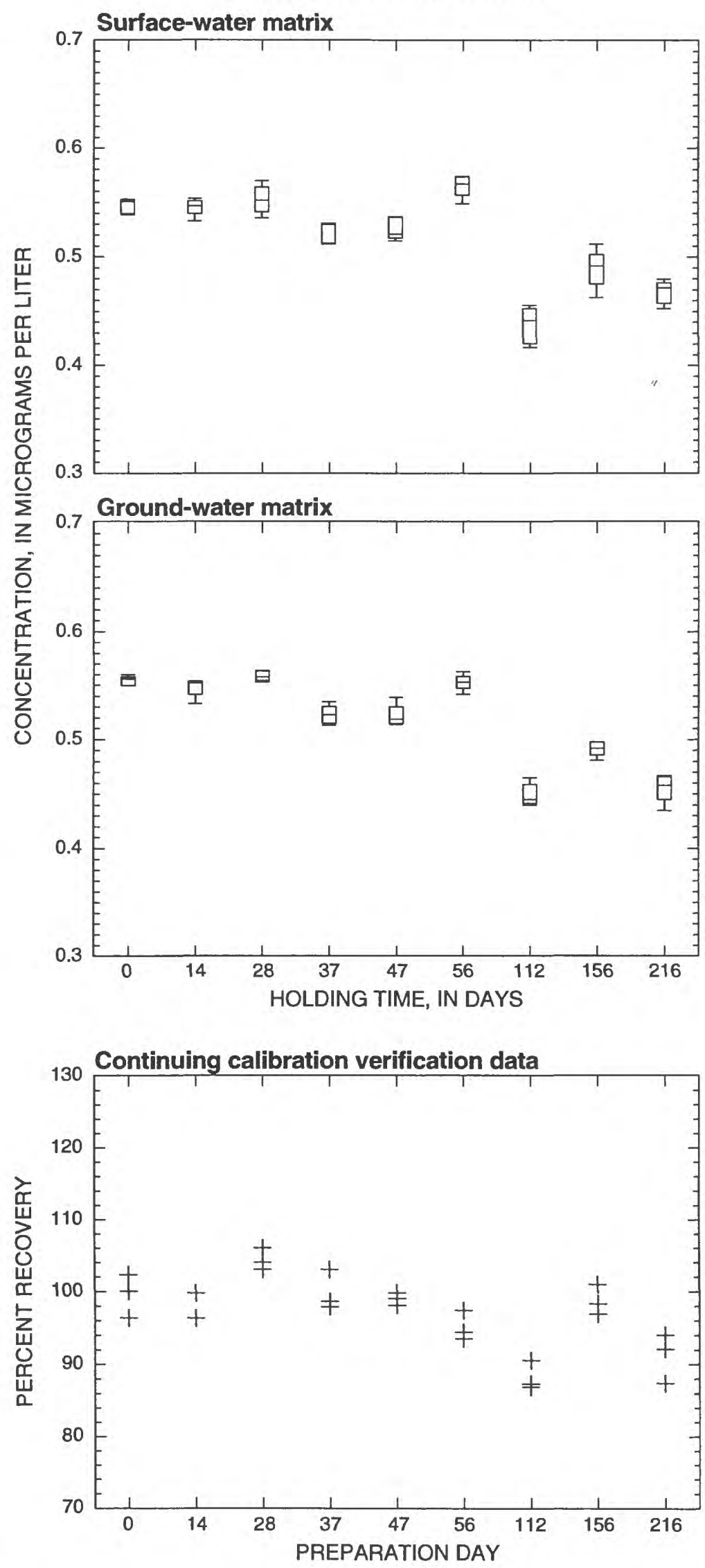
Tetrachloromethane
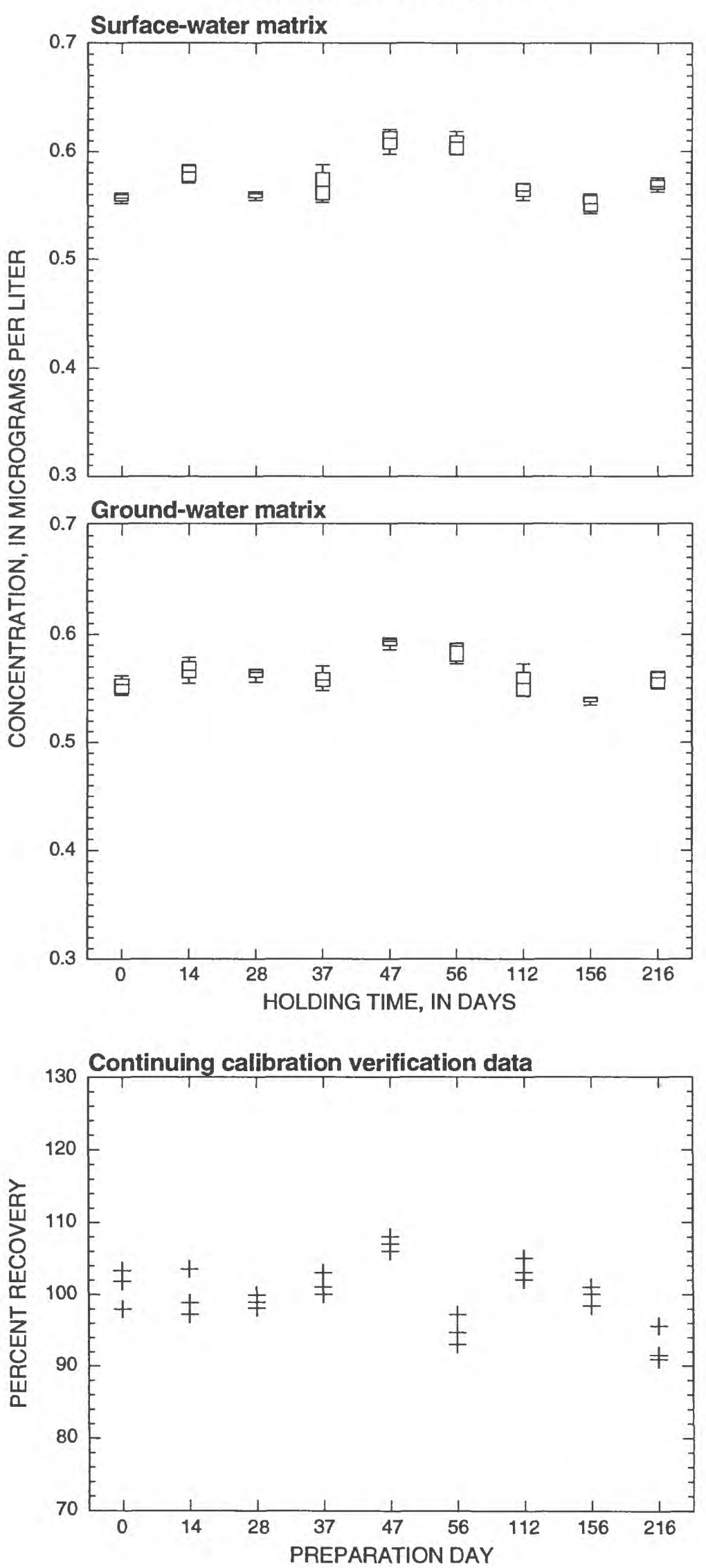


\section{Tribromomethane}
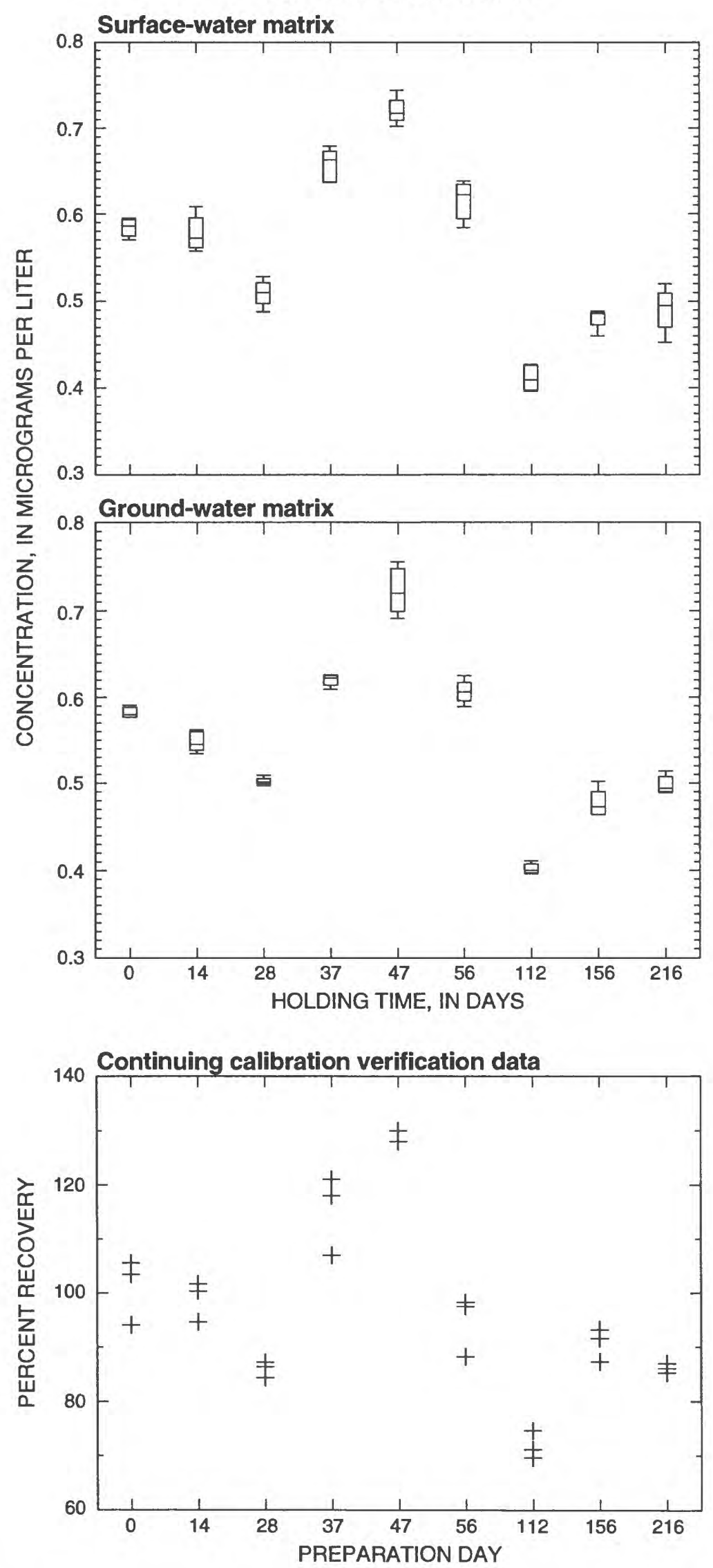


\section{1,1,2-Trichloro-1,2,2-trifluoroethane}
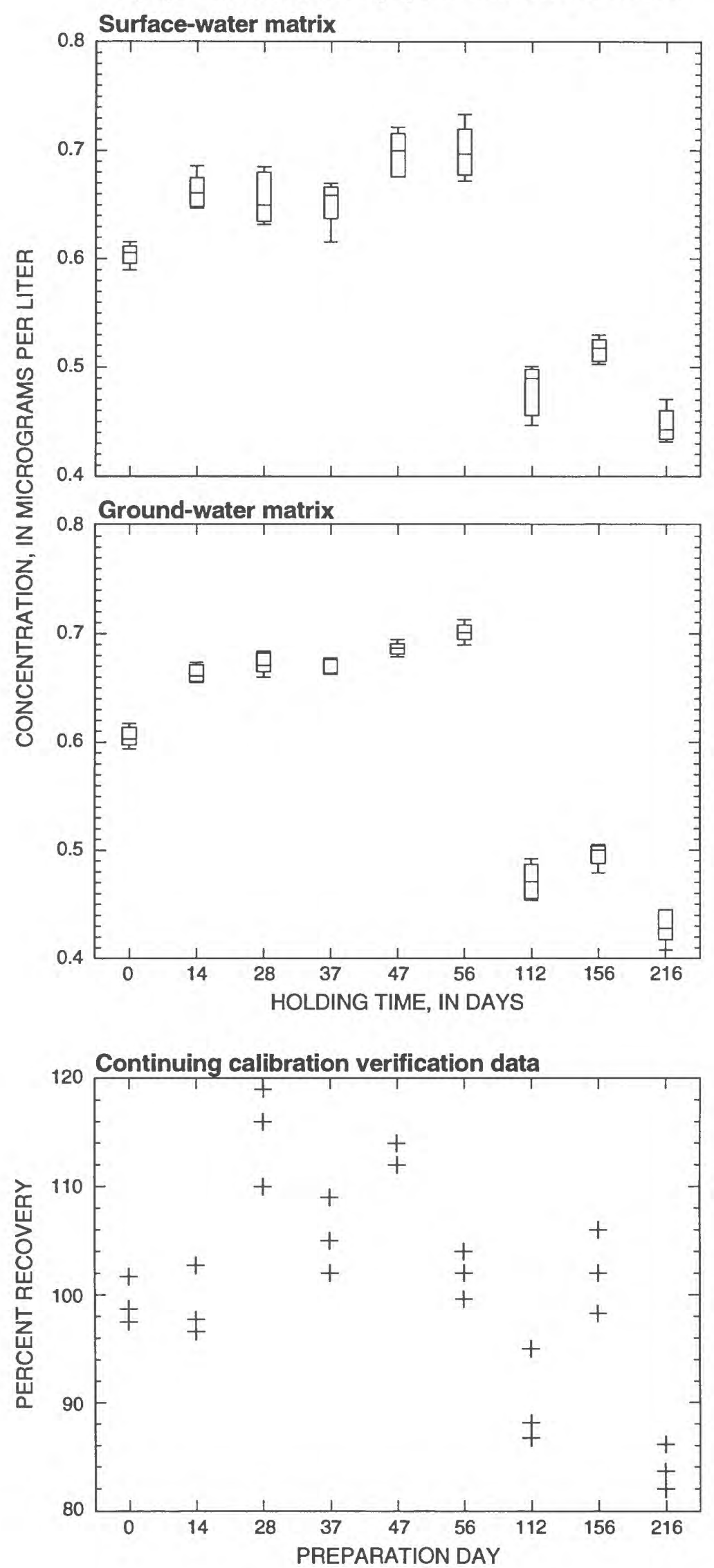
1,2,3-Trichlorobenzene
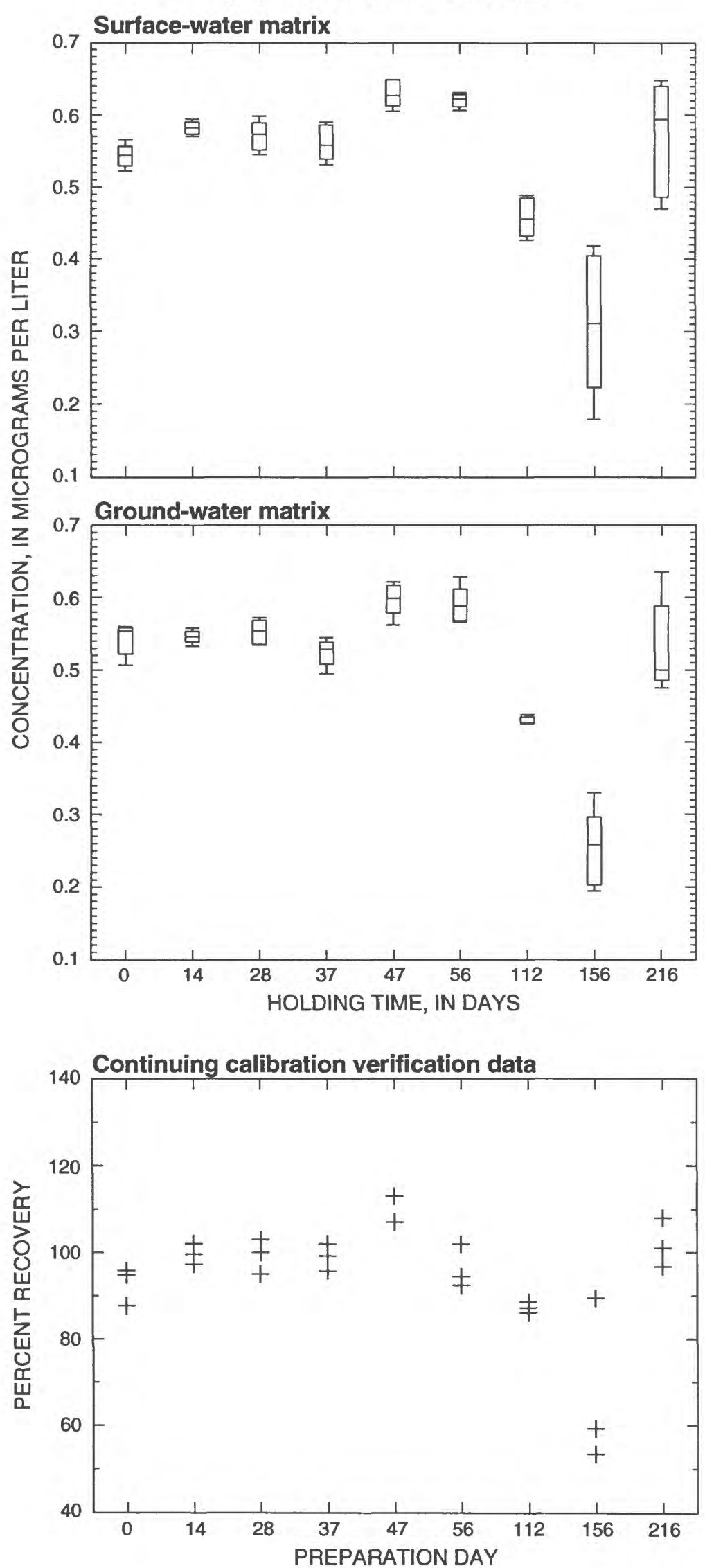
1,2,4-Trichlorobenzene
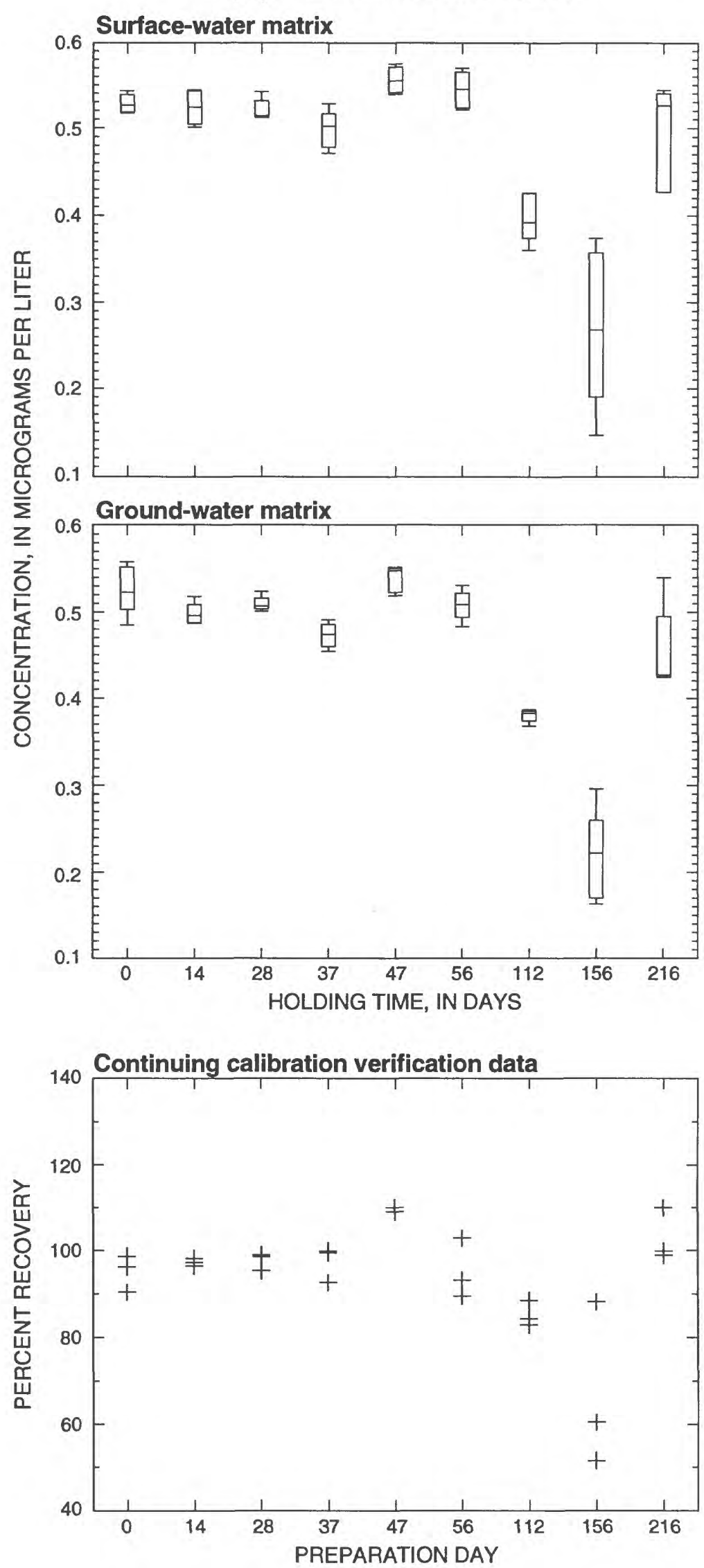
1,1,1-Trichloroethane
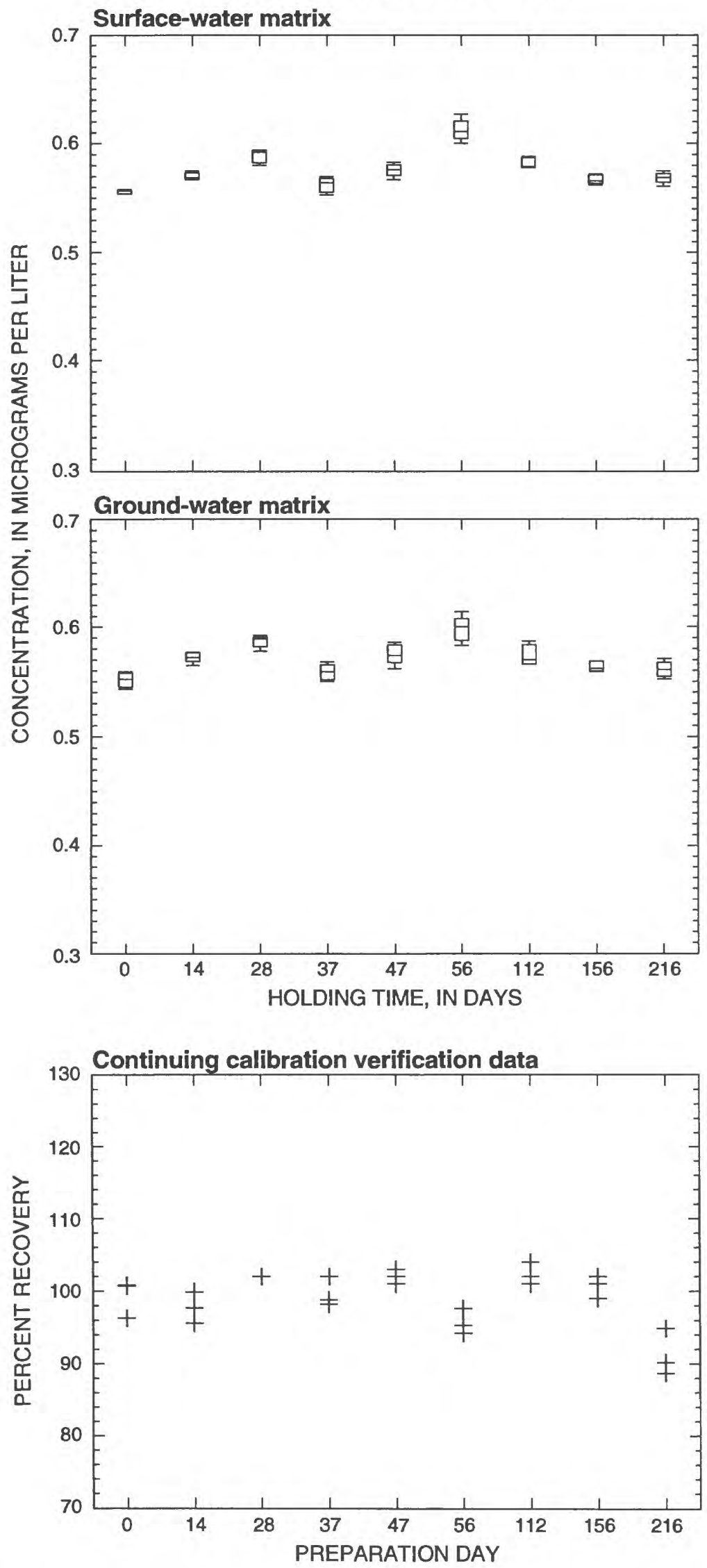
1,1,2-Trichloroethane
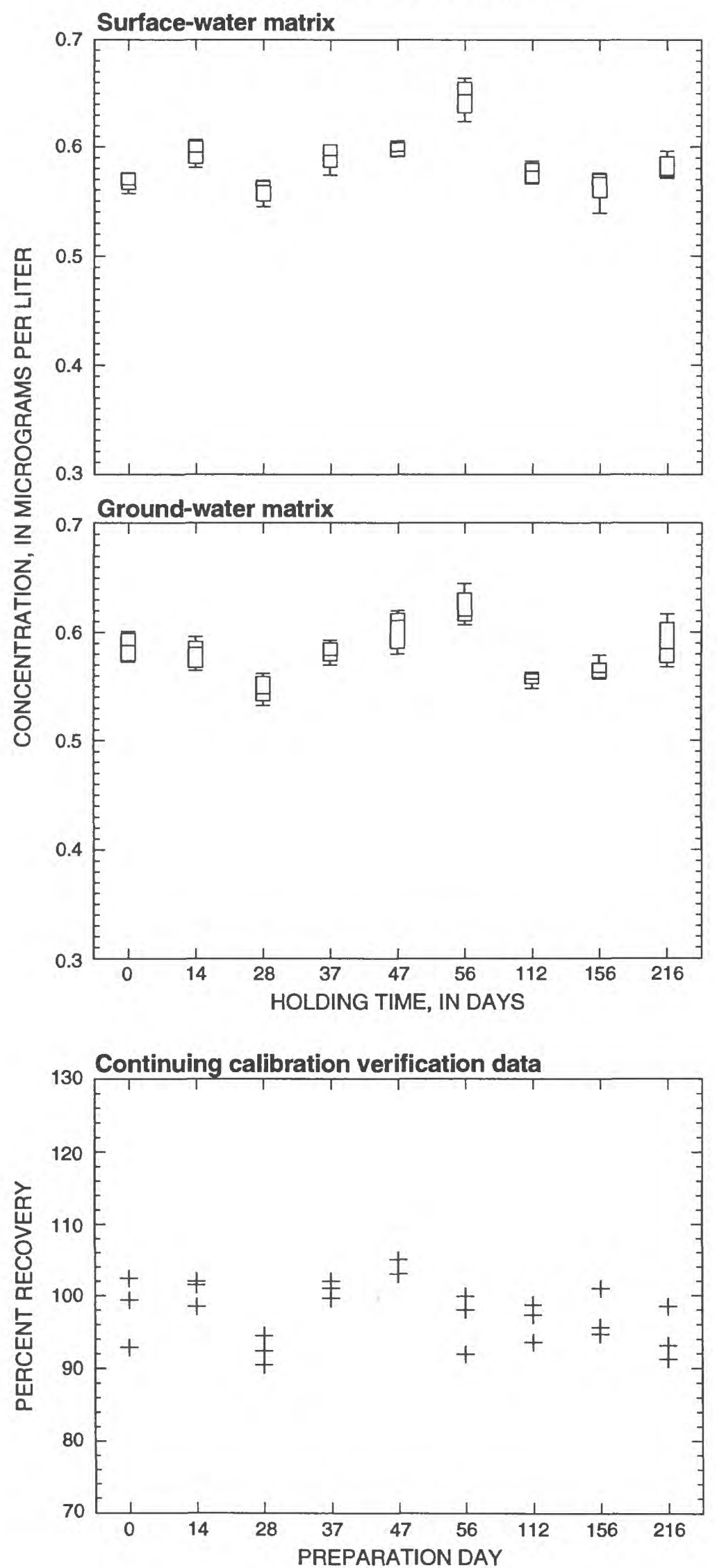


\section{Trichloroethene}
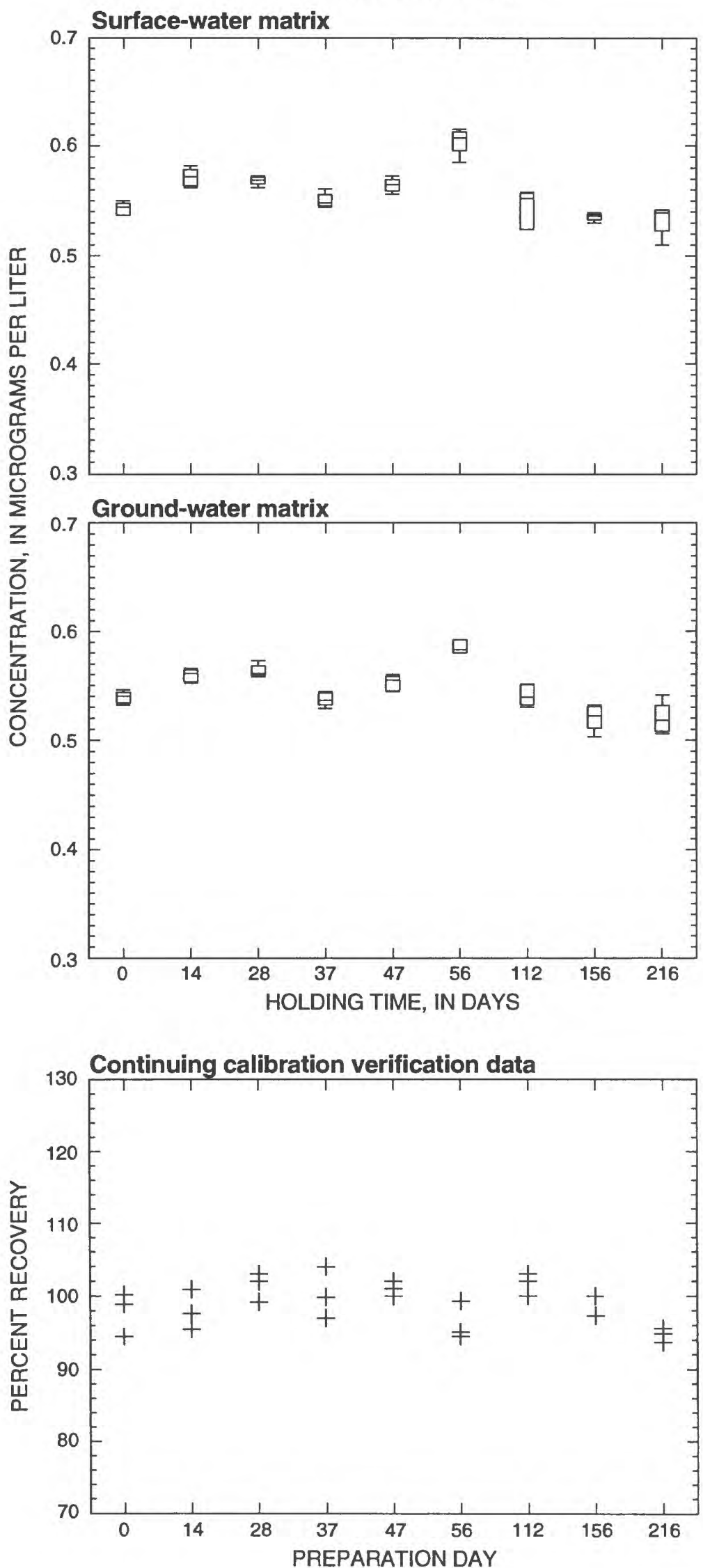
Trichlorofluoromethane
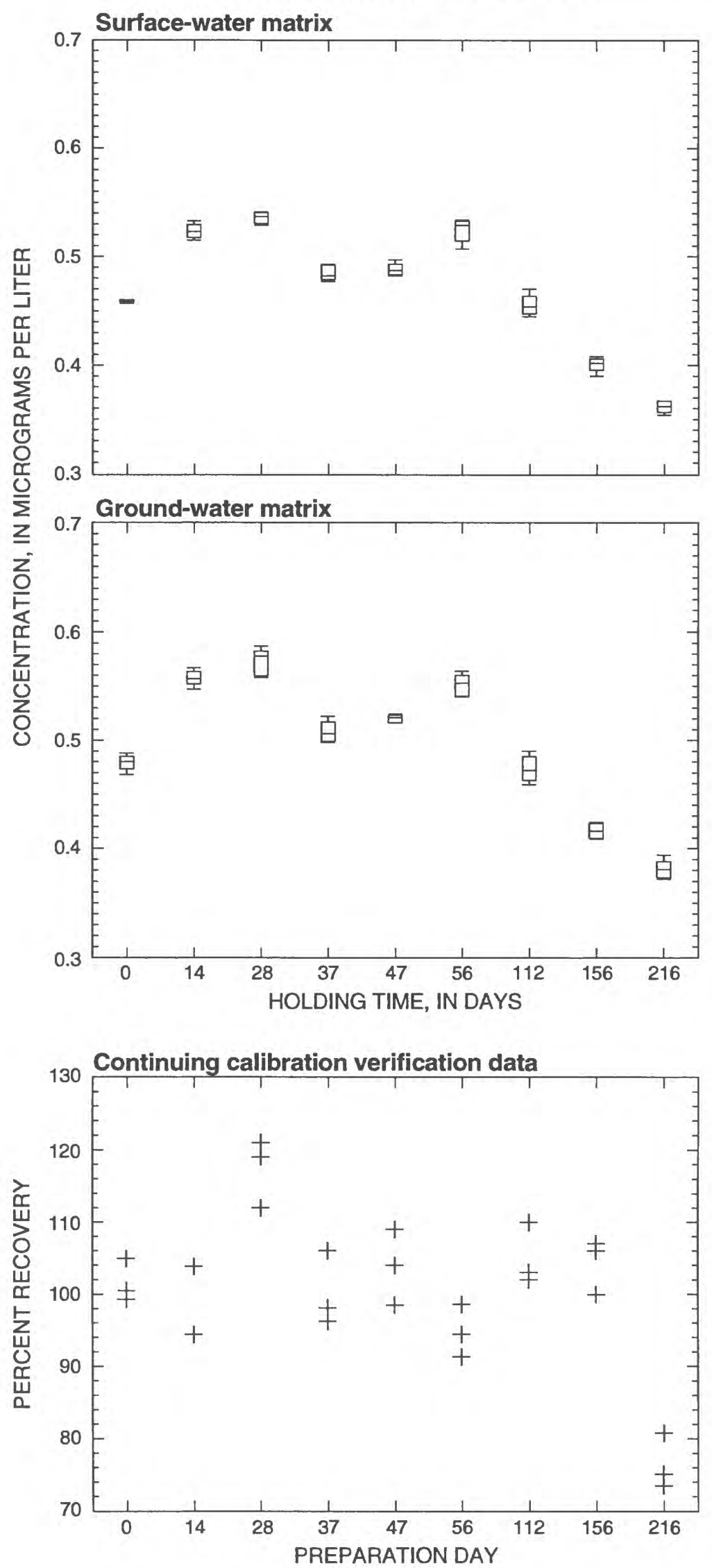


\section{Trichloromethane}
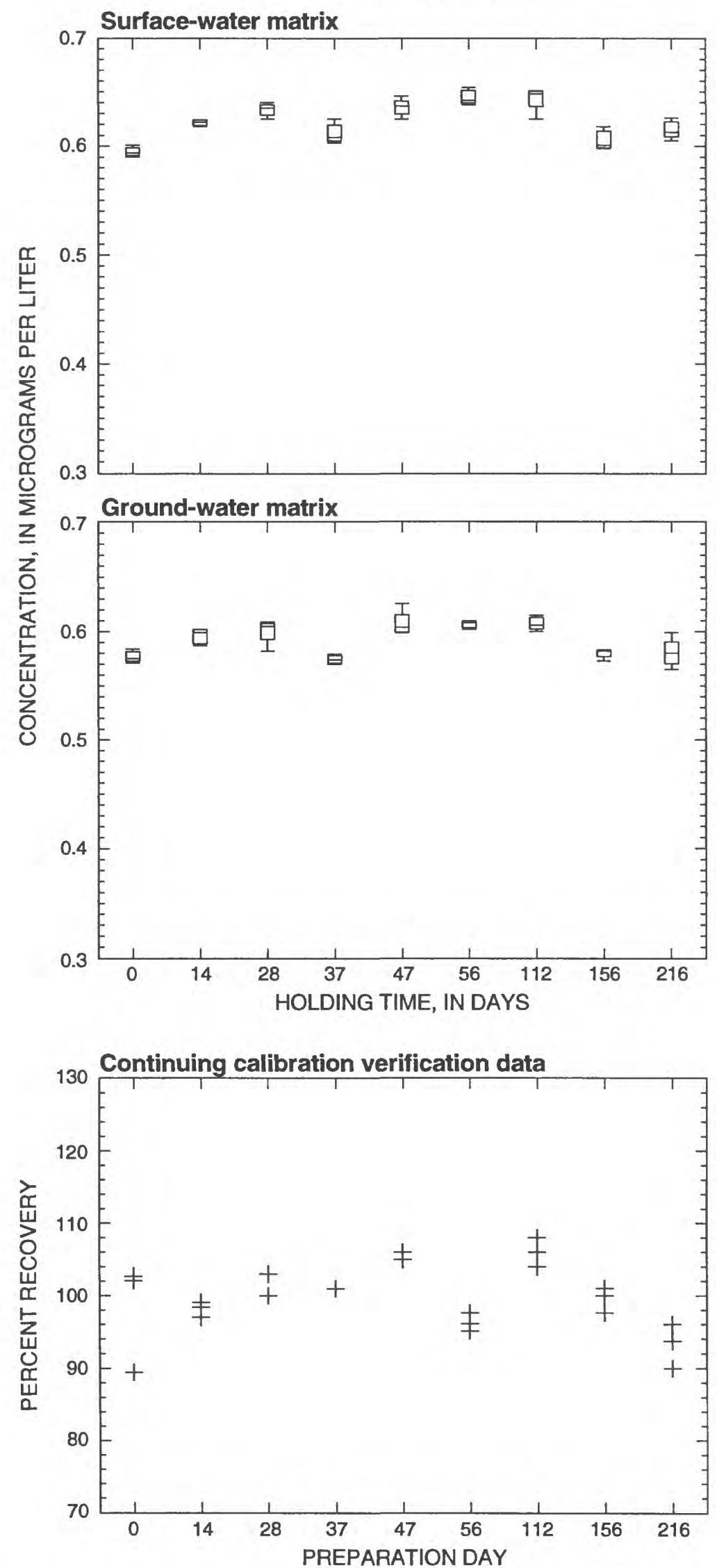


\section{1,2,3-Trichloropropane}
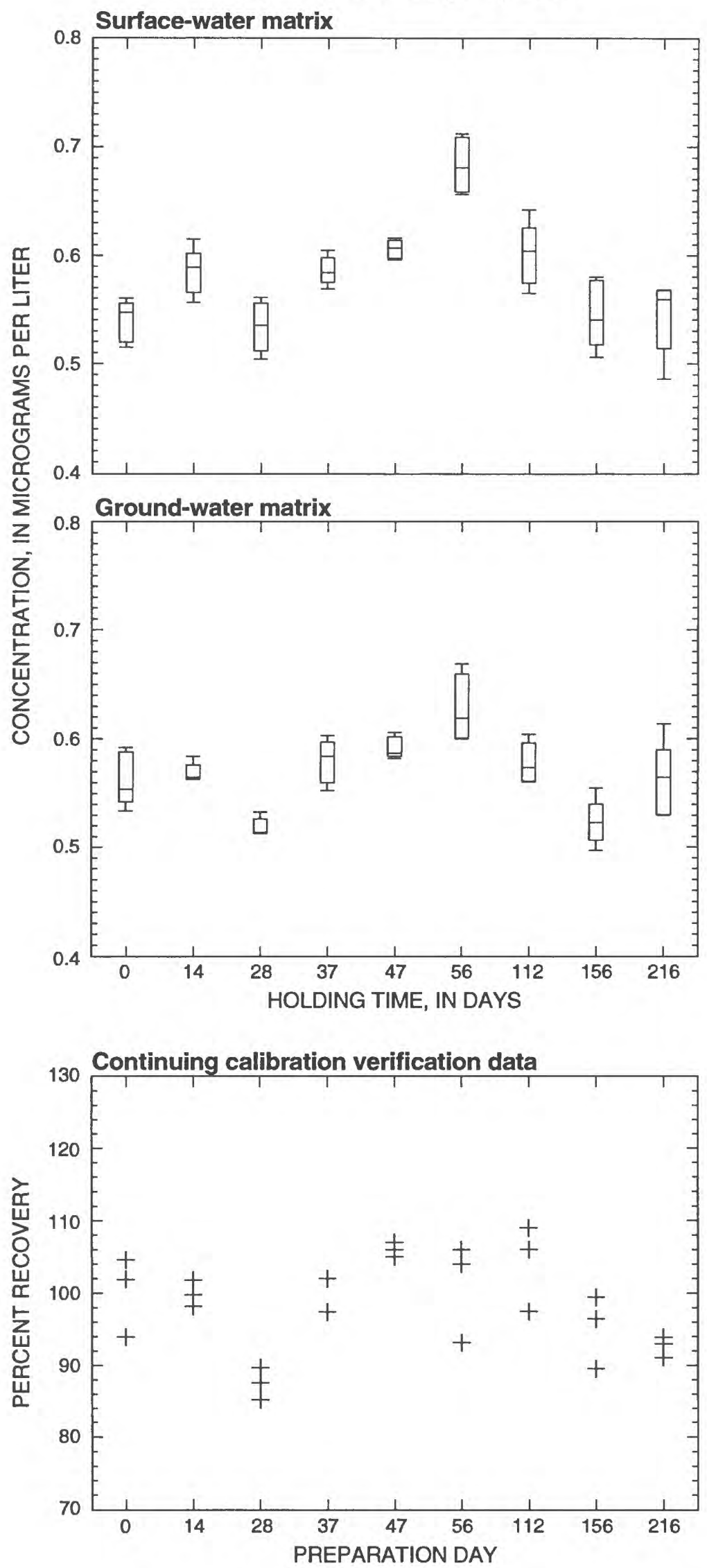
1,2,4-Trimethylbenzene
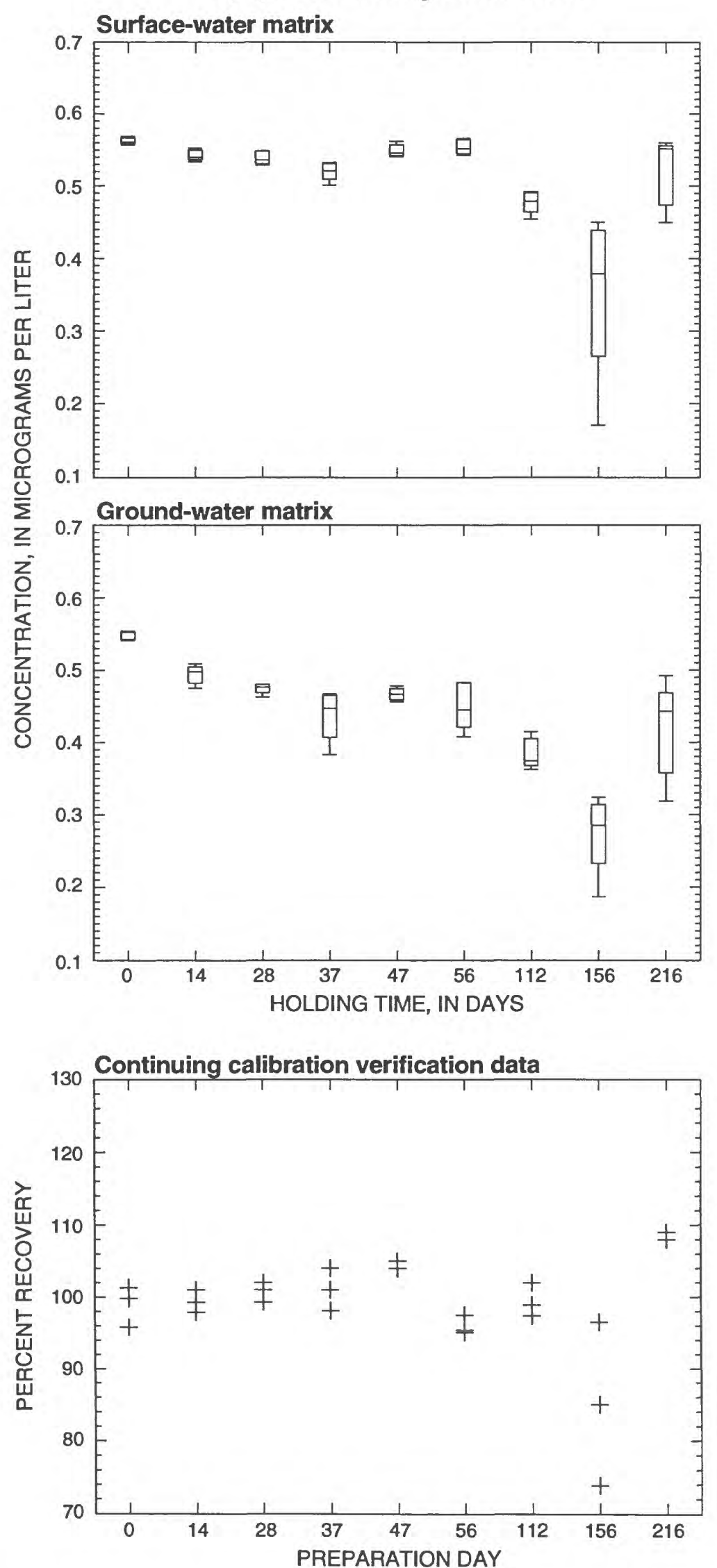

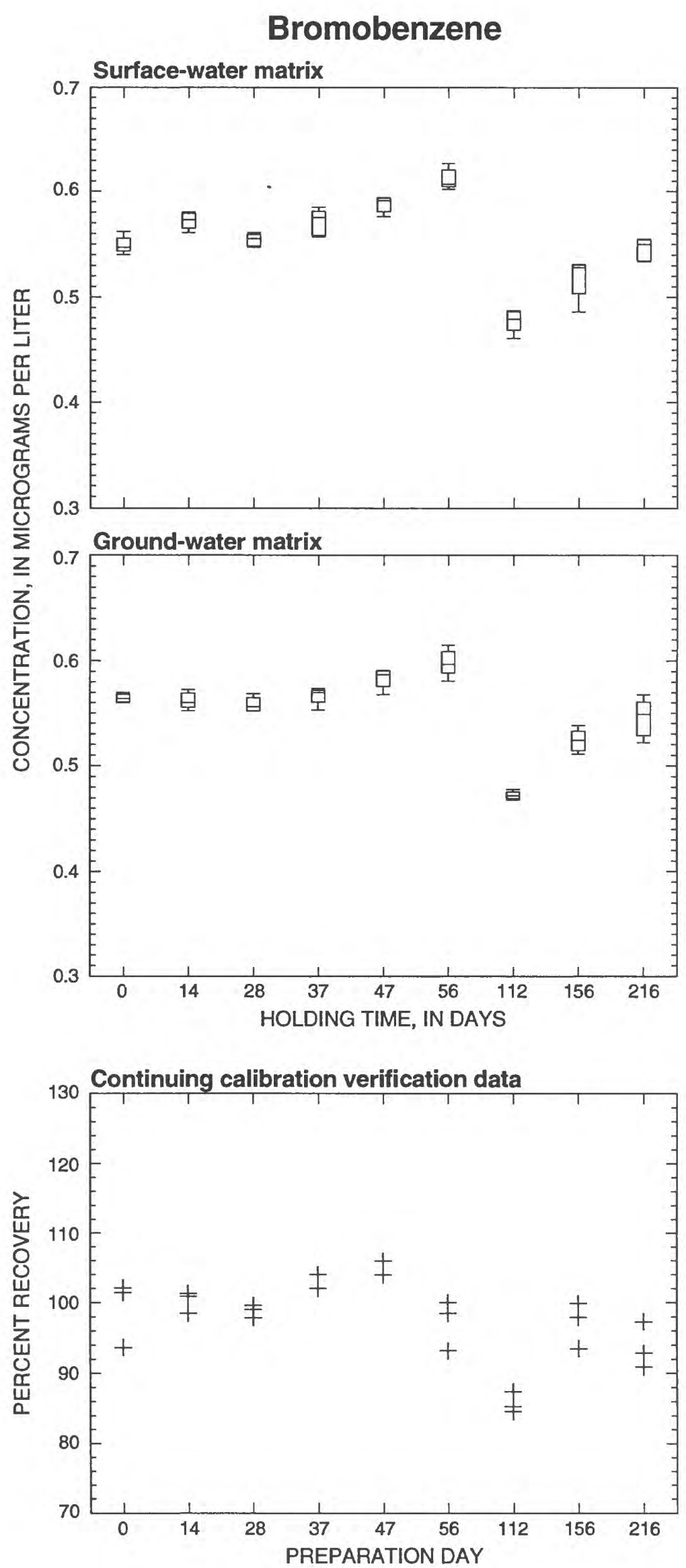

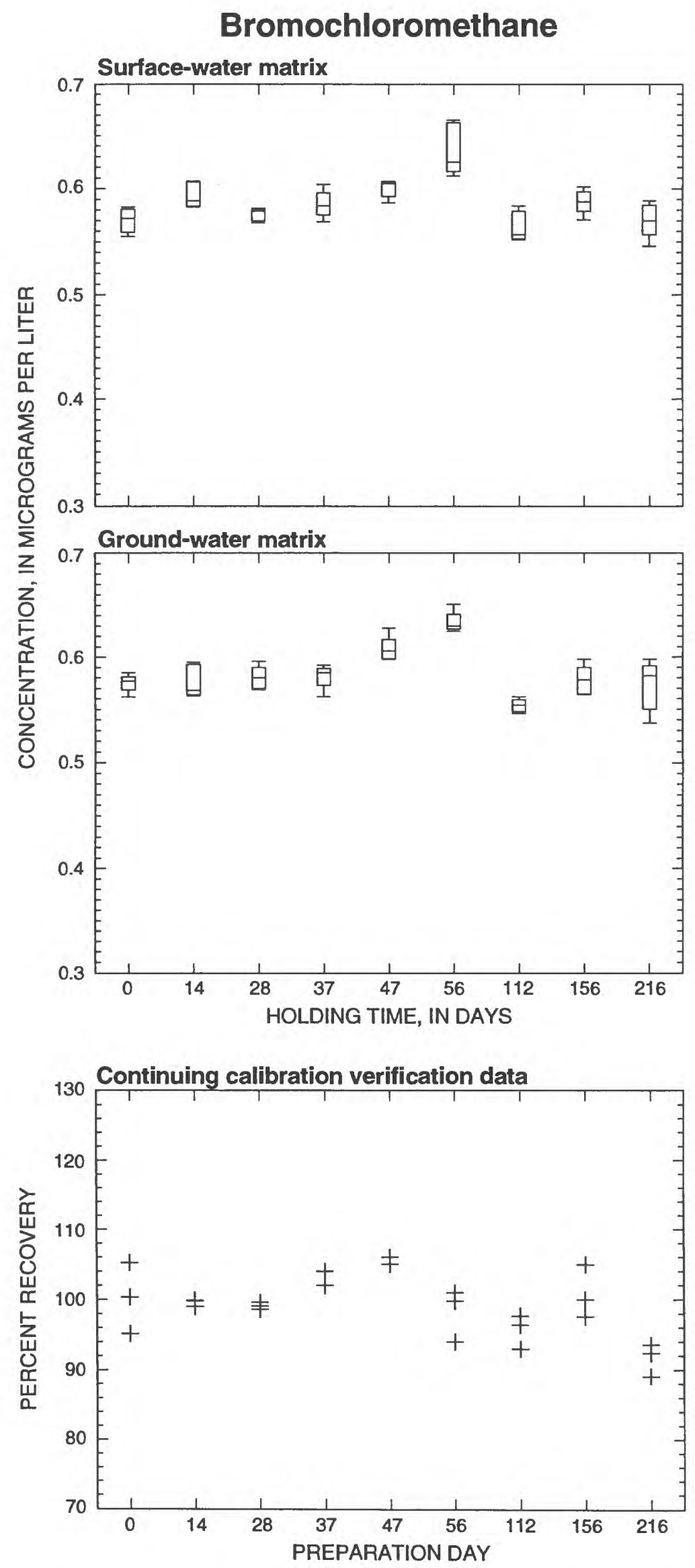
2-Butanone
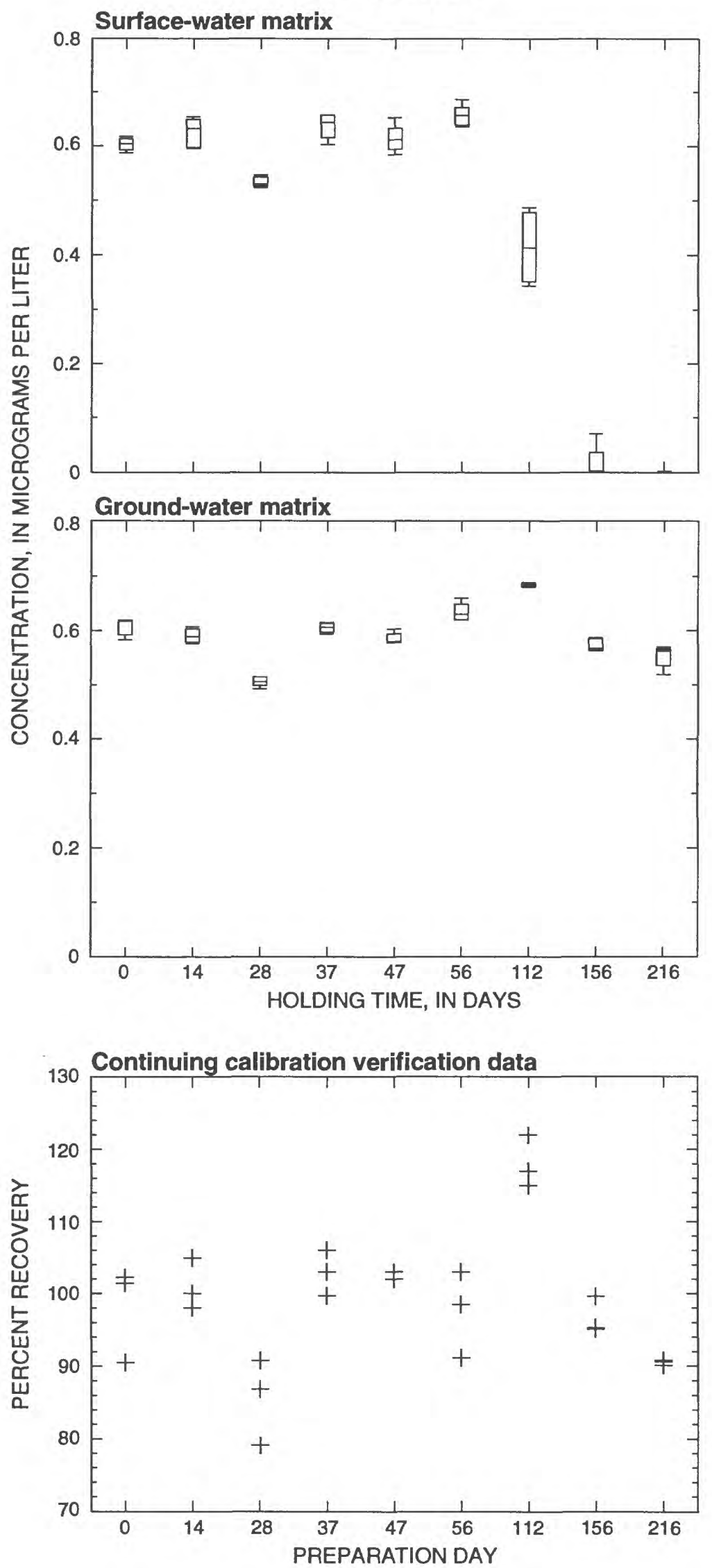
Carbon disulfide
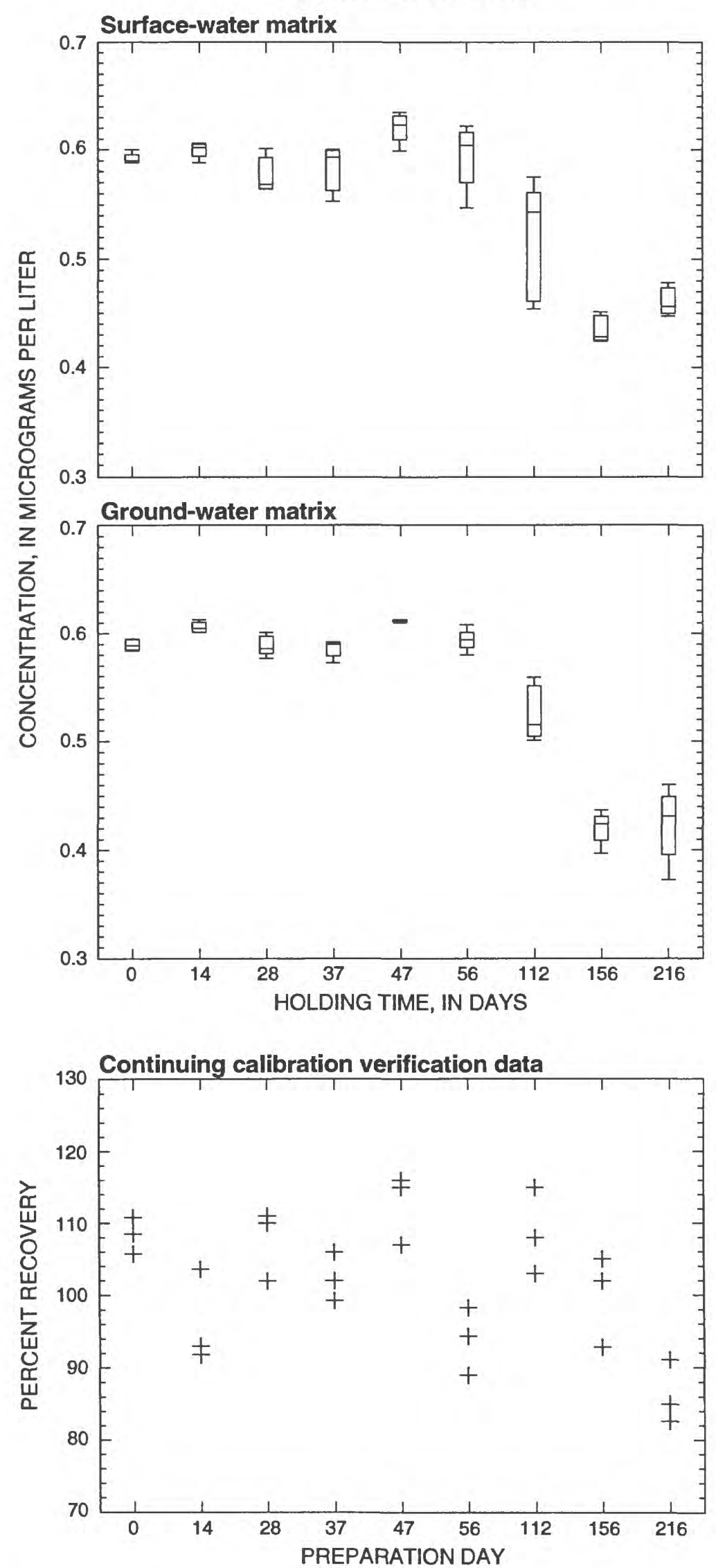


\section{1-Chloro-2-methylbenzene}
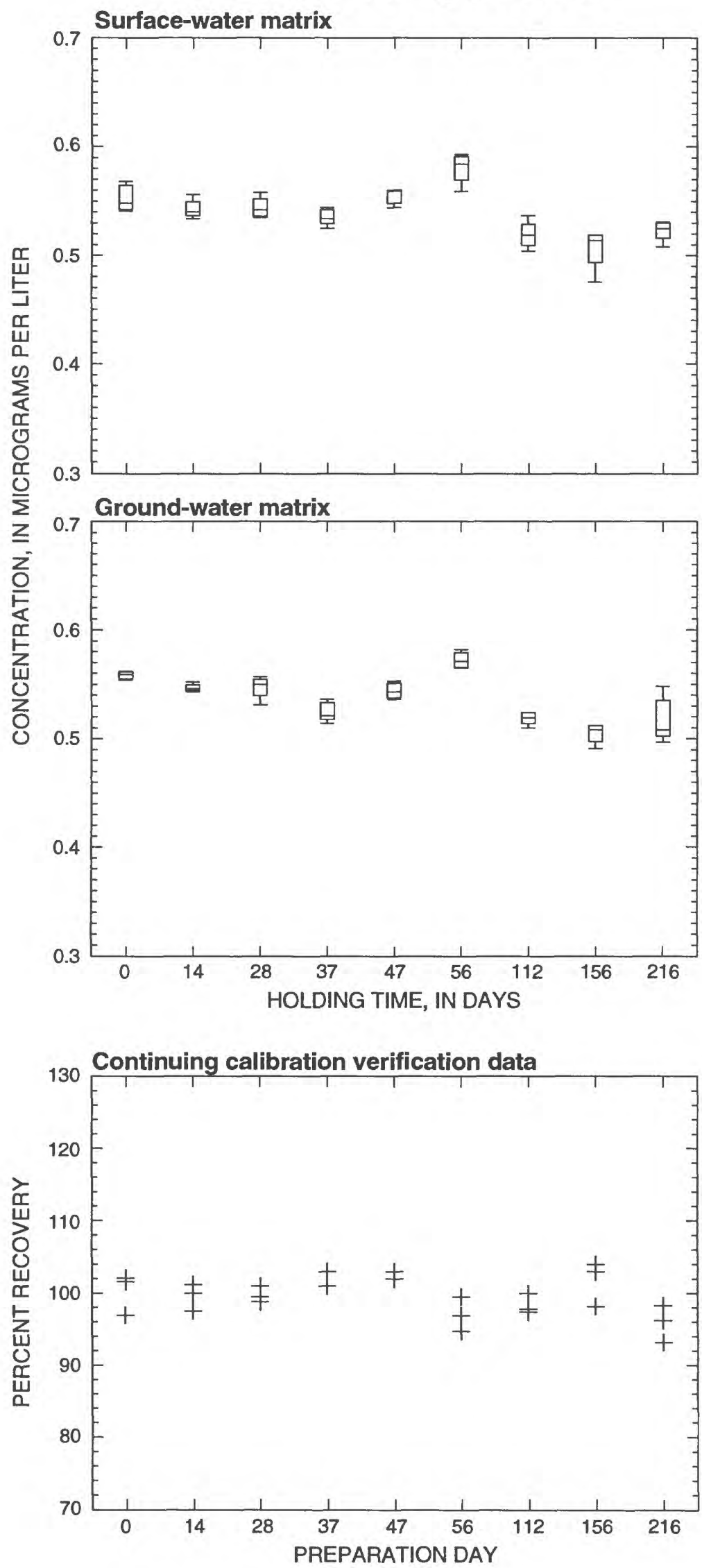
1-Chloro-4-methylbenzene
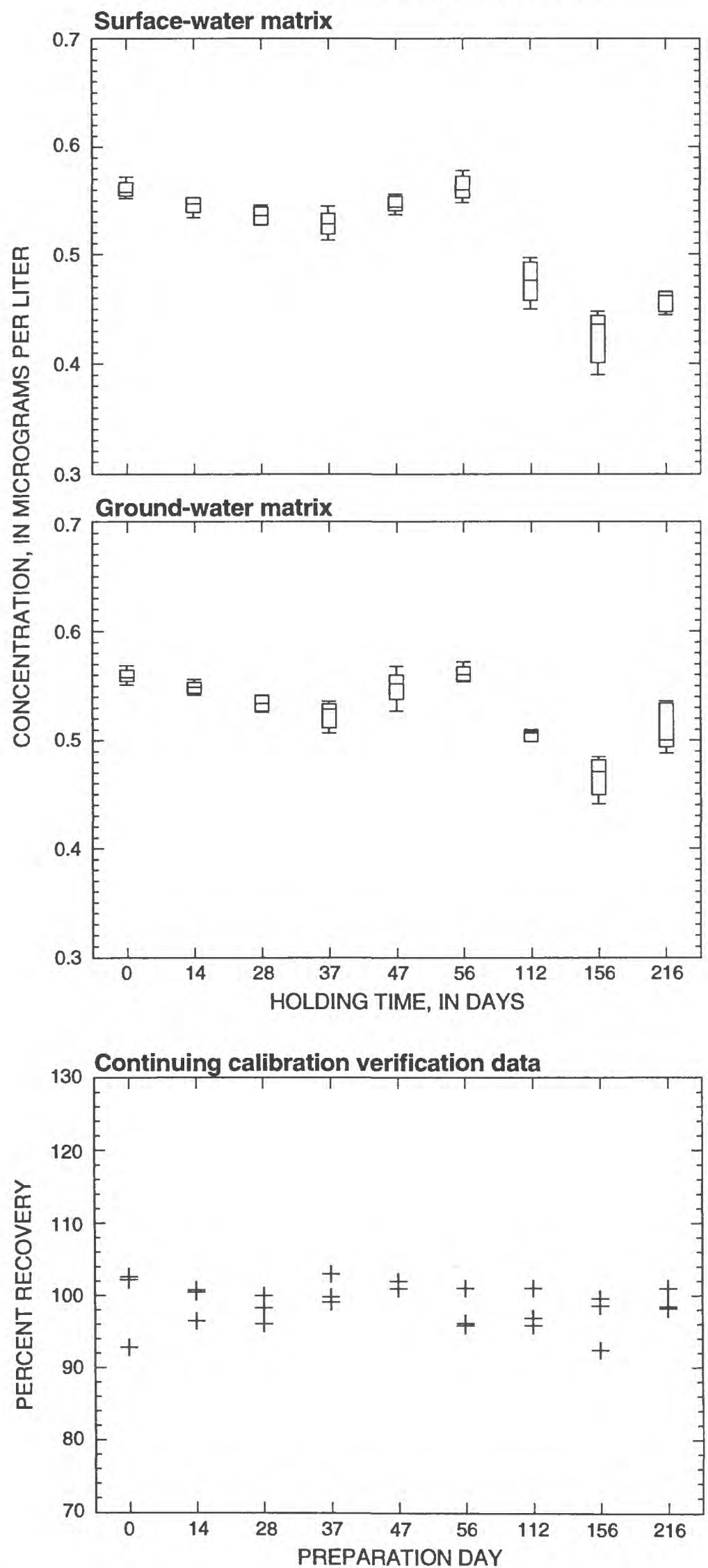
3-Chloro-1-propene
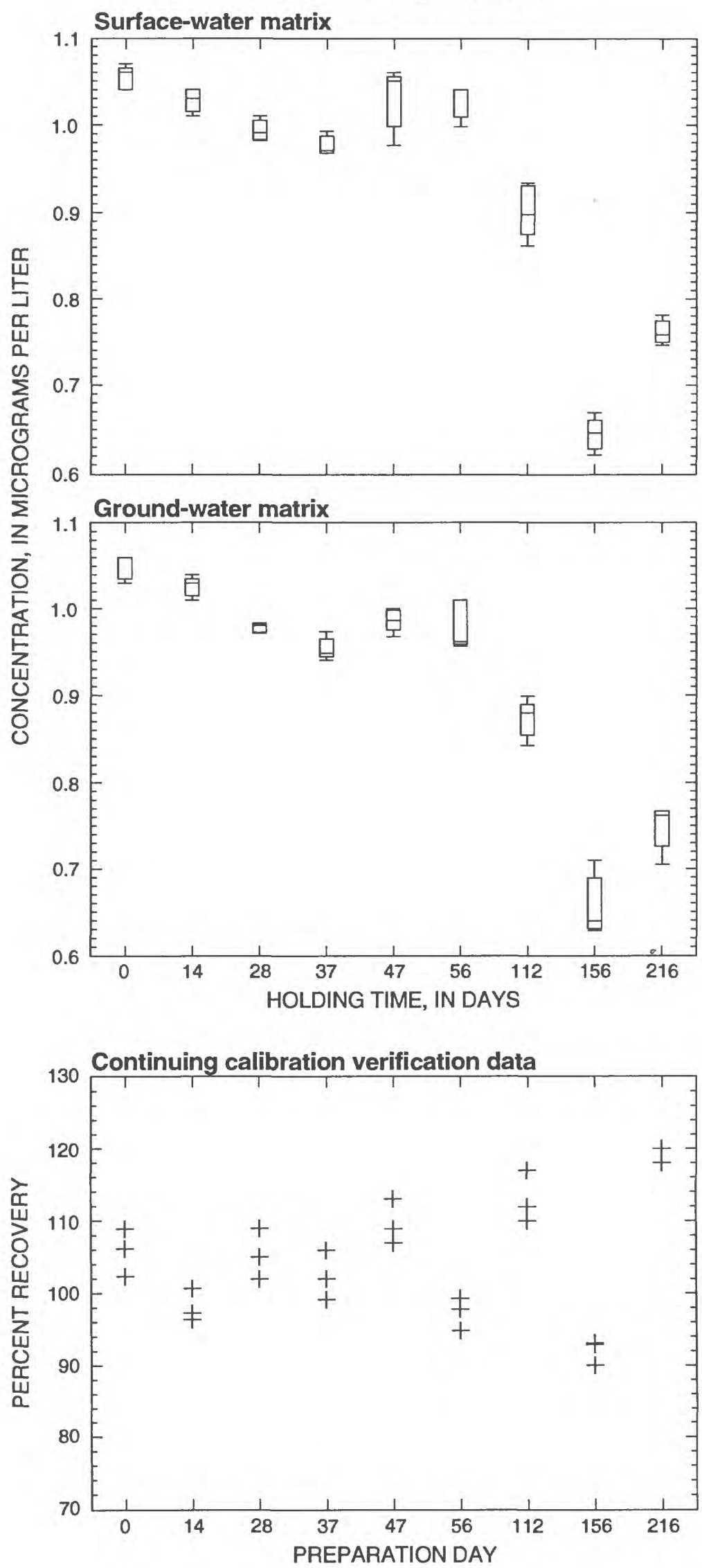


\section{Dibromomethane}
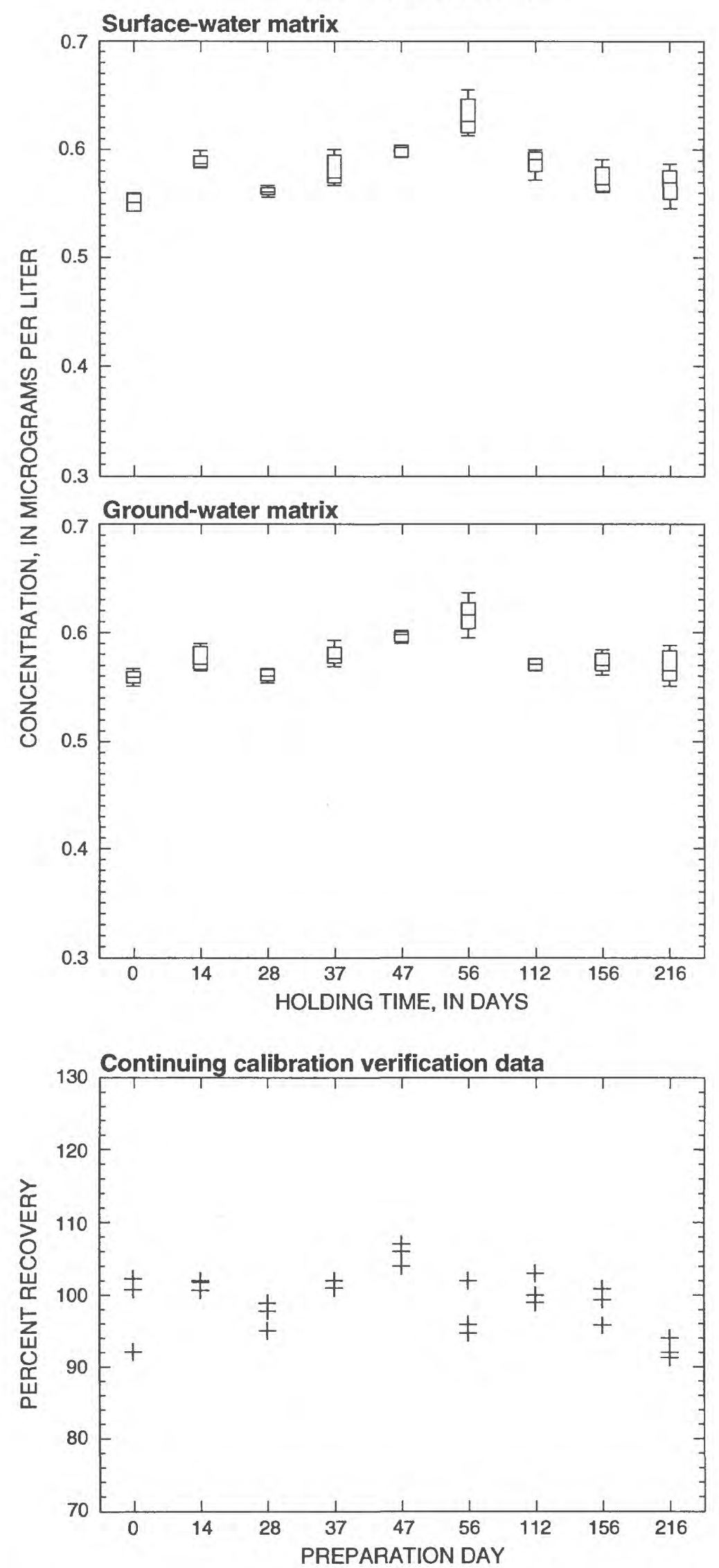
trans-1,4-Dichloro-2-butene
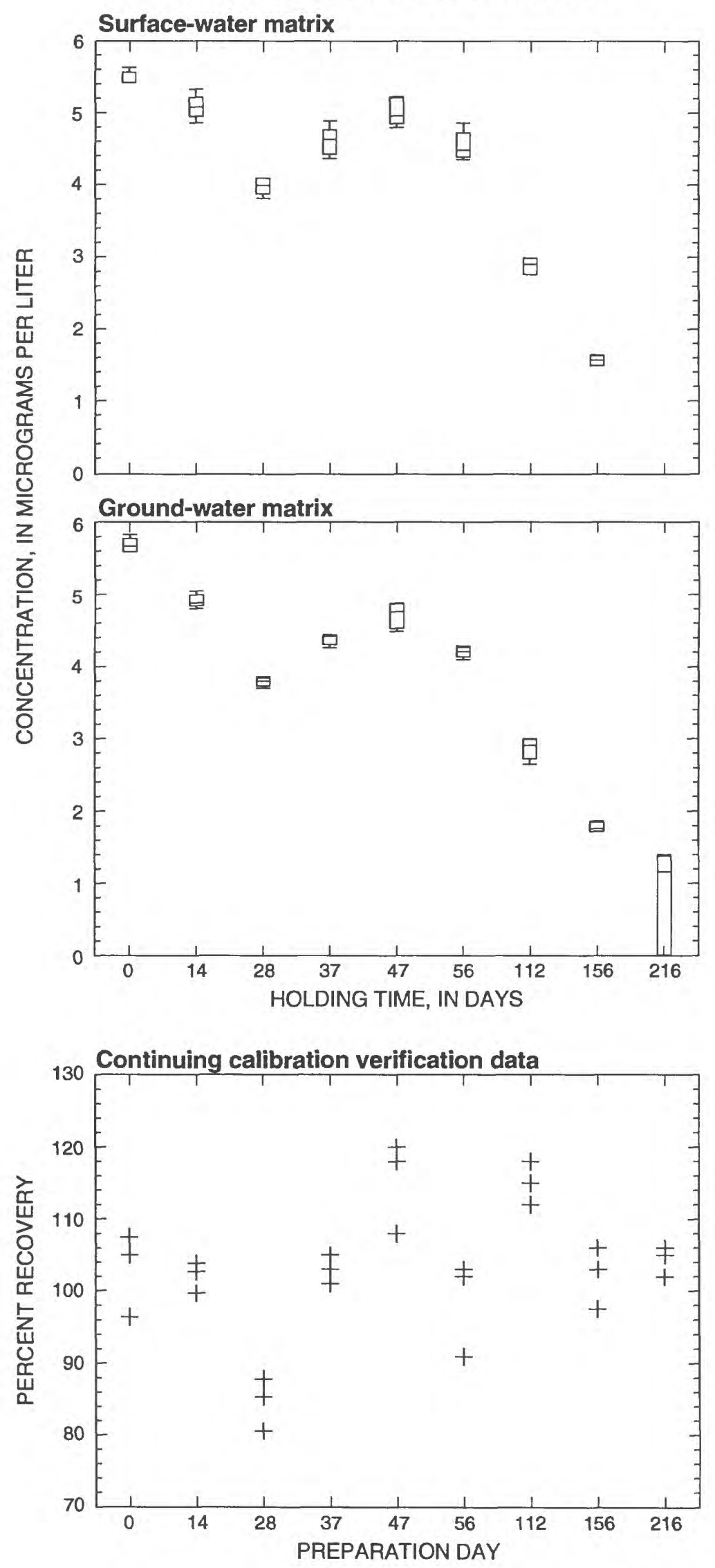
1,3-Dichloropropane
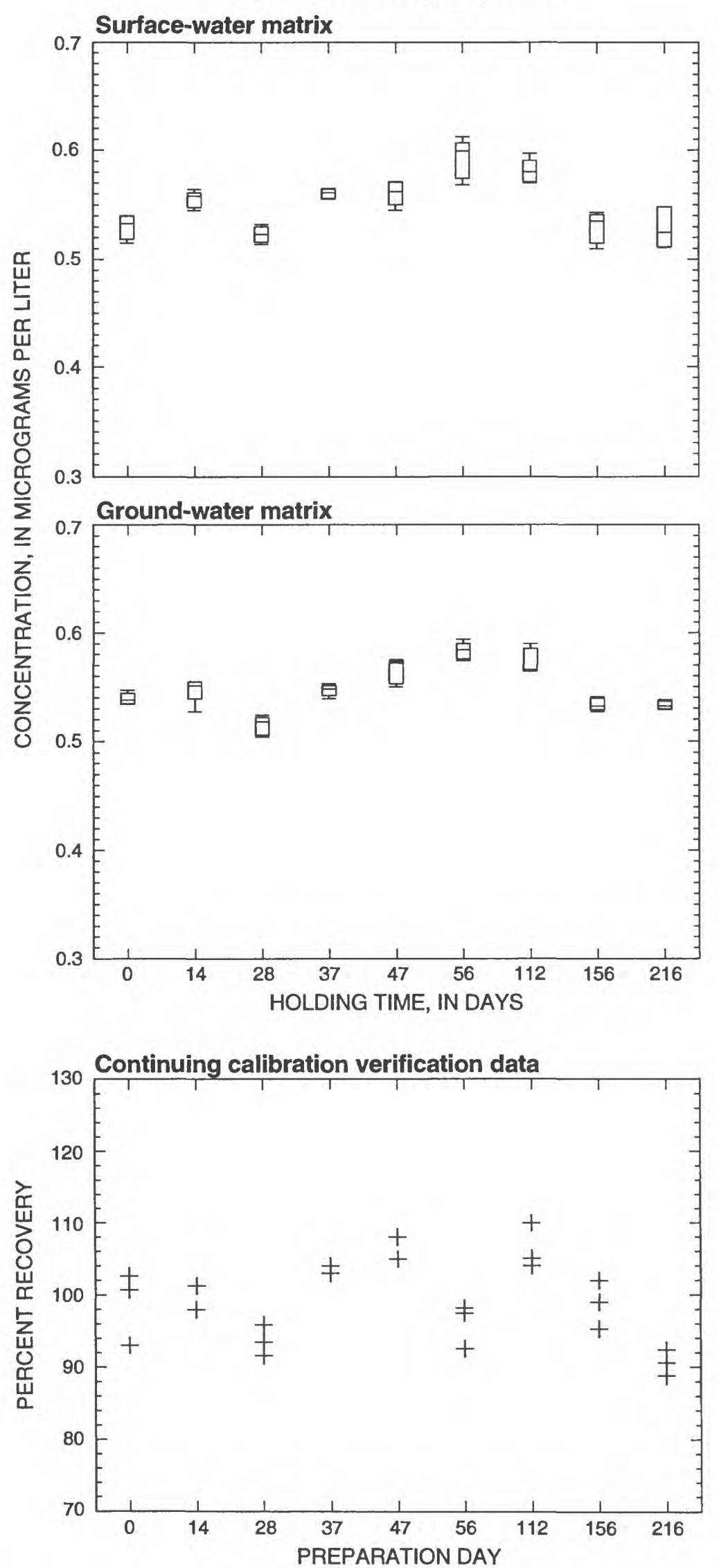

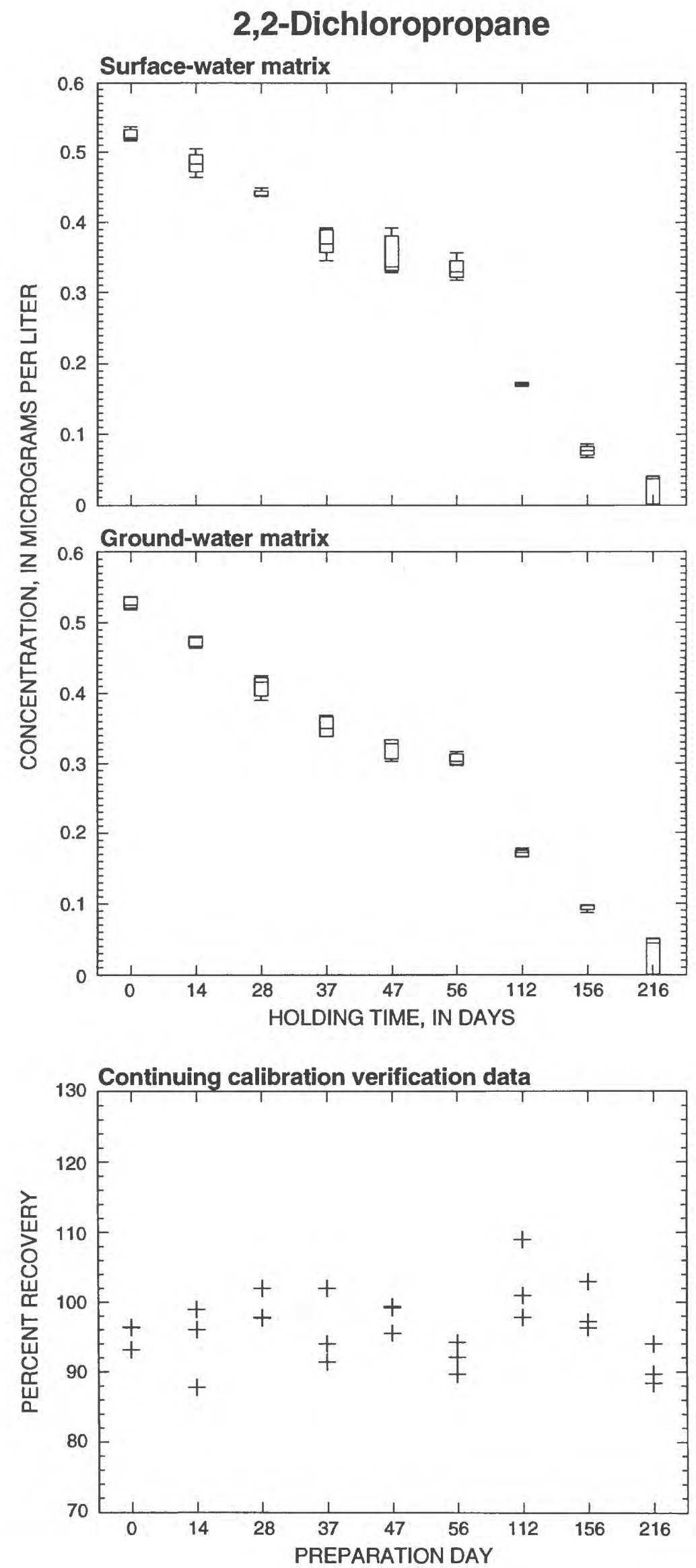
1,1-Dichloropropene
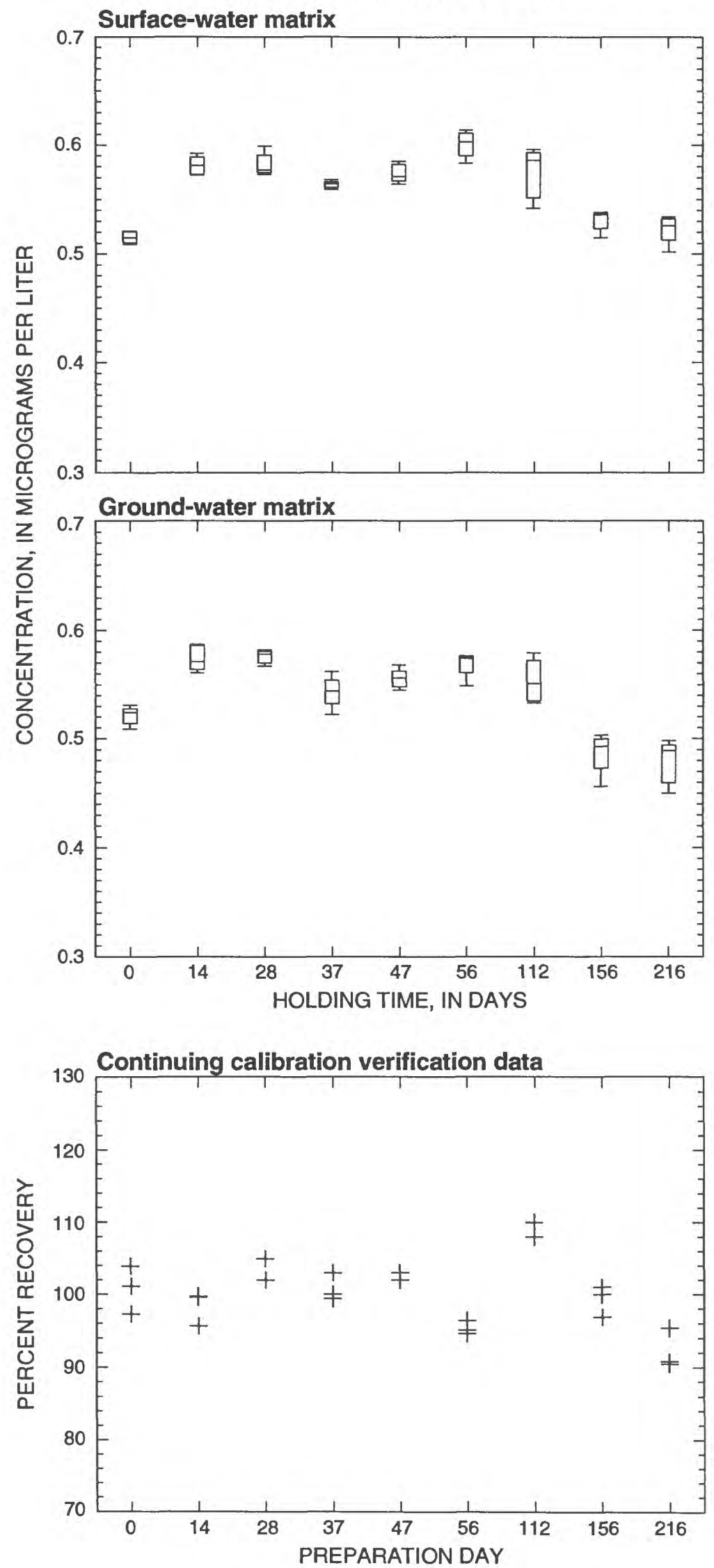
(1,1-Dimethylethyl)benzene
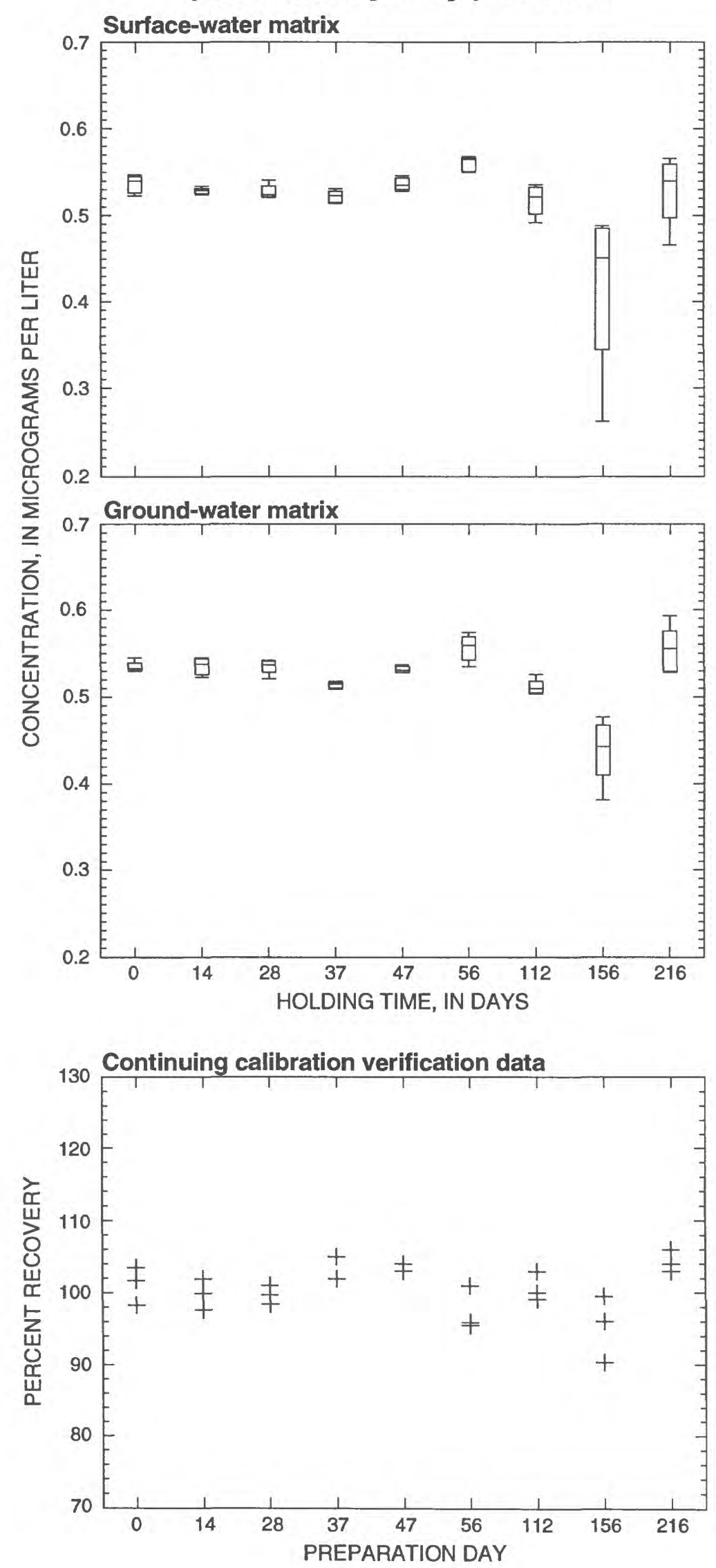

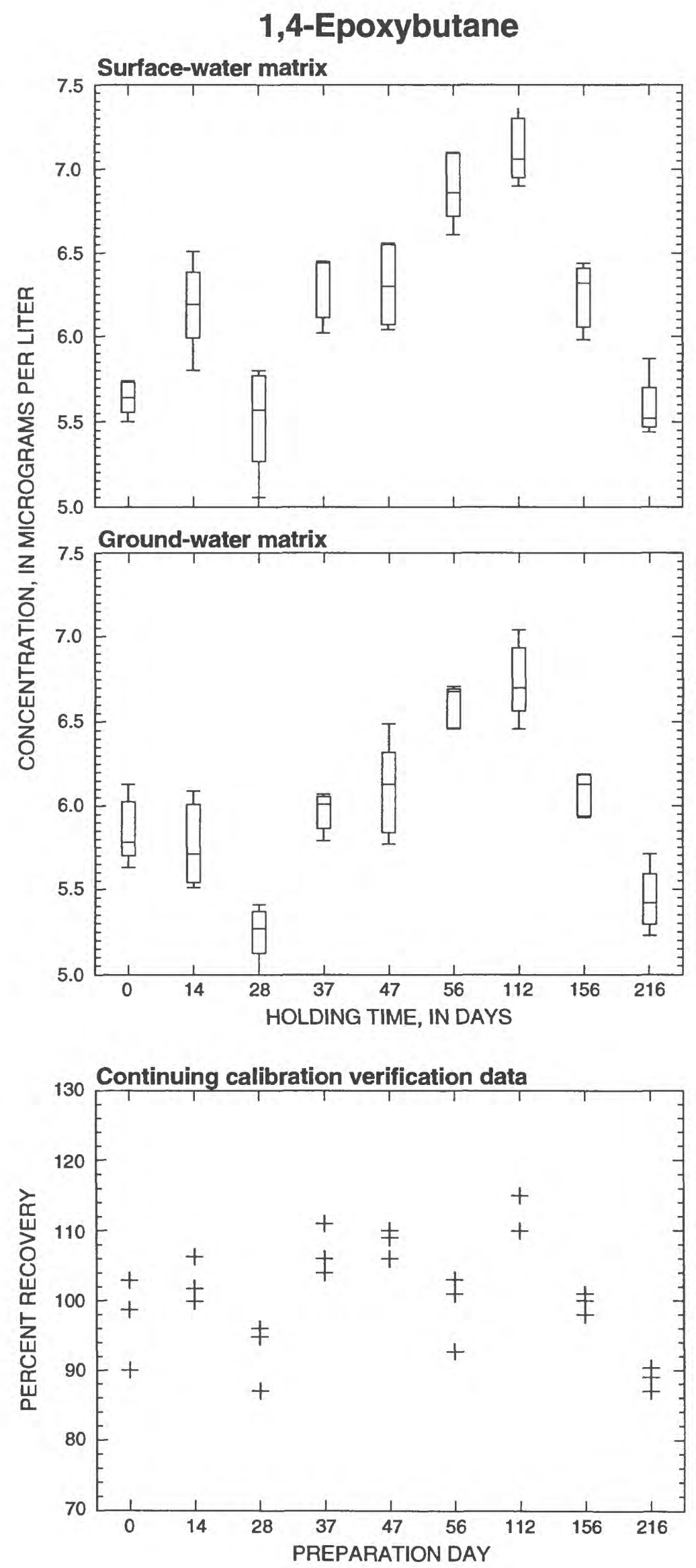
1-Ethyl-2-methylbenzene
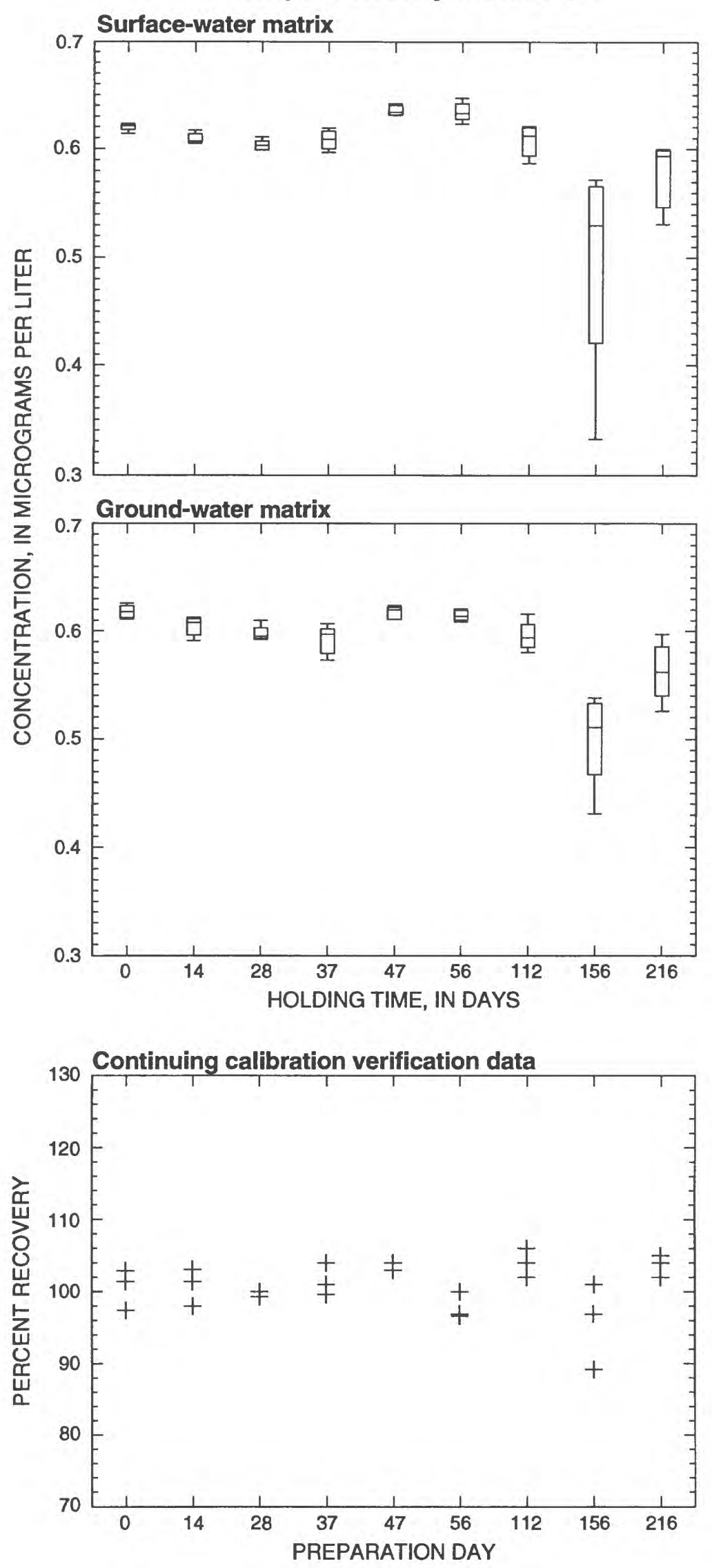
Ethyl 2-methyl-2-propenoate
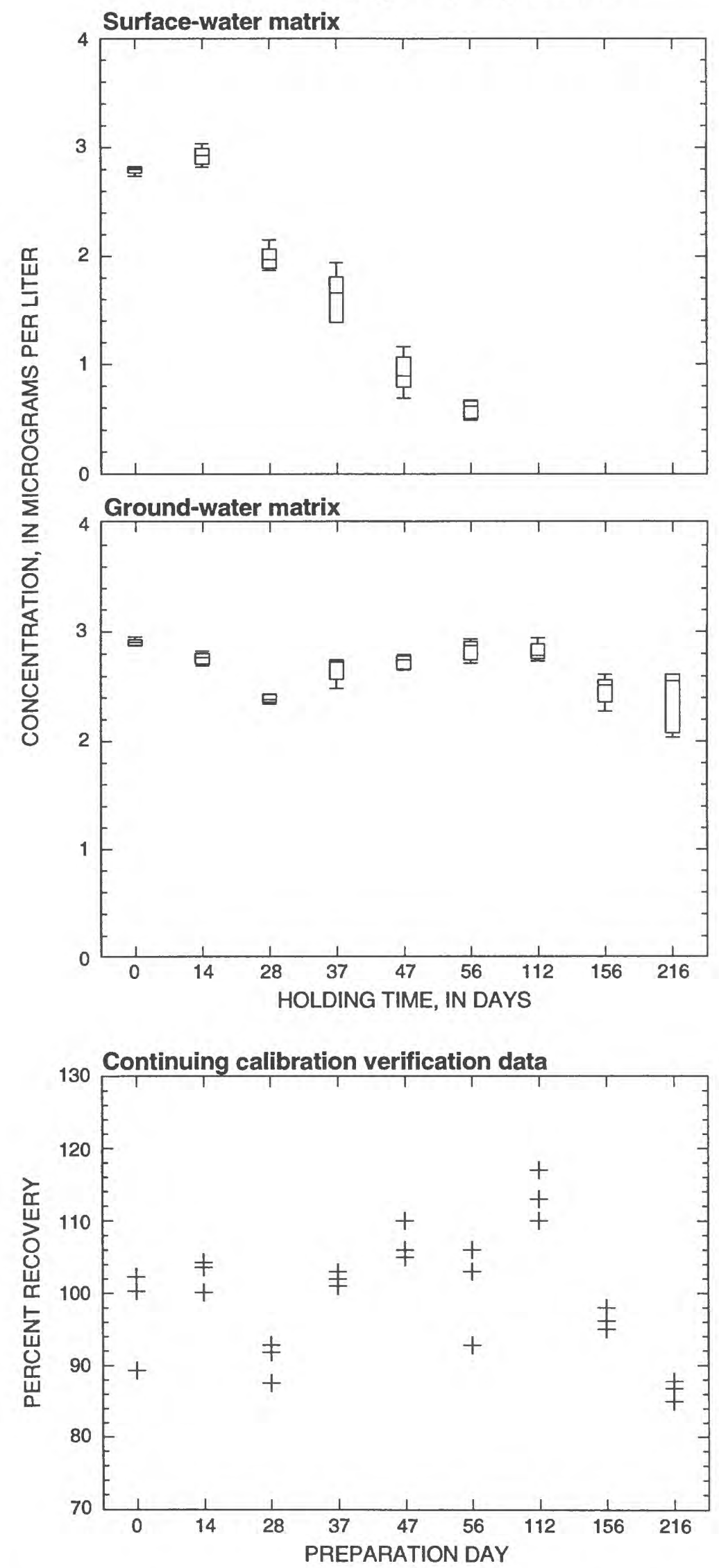
2-Hexanone
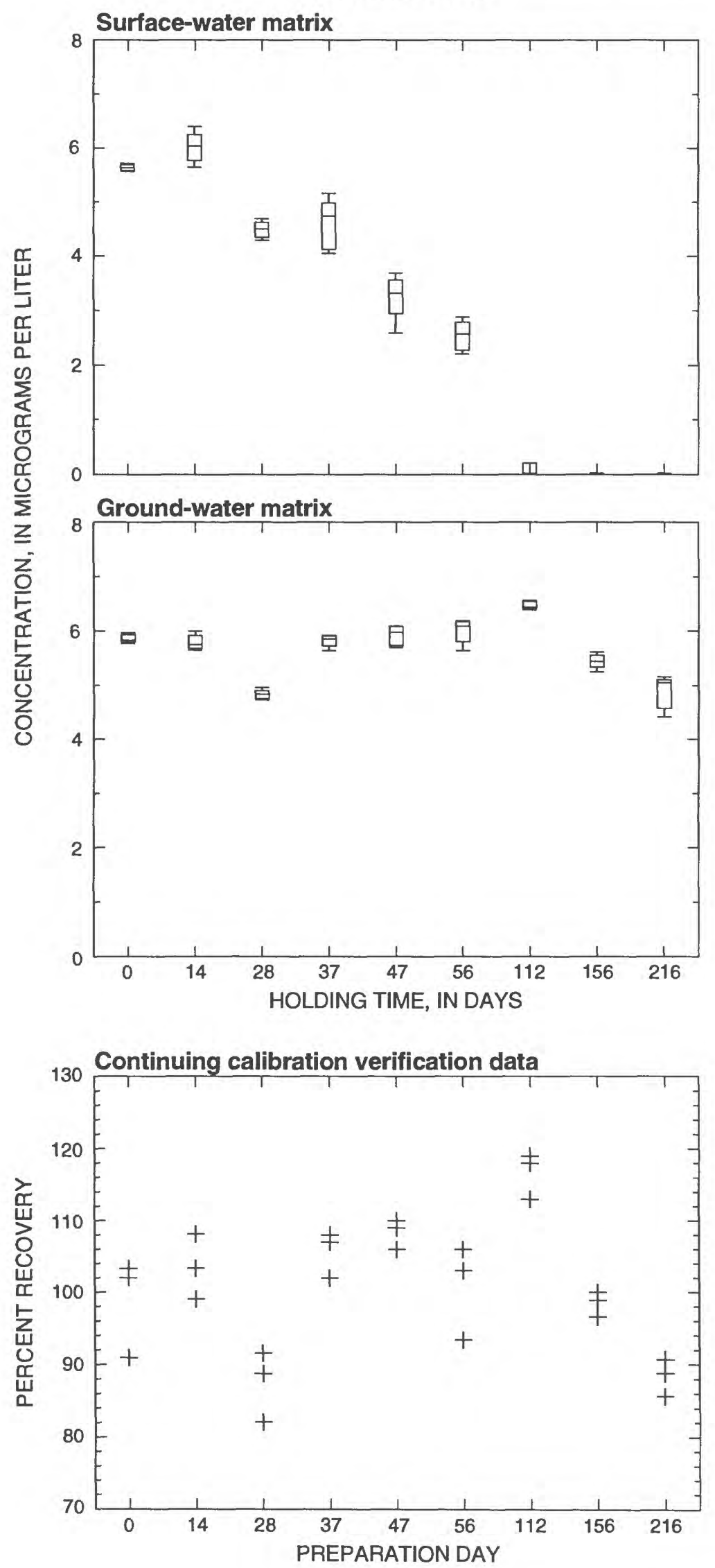
lodomethane
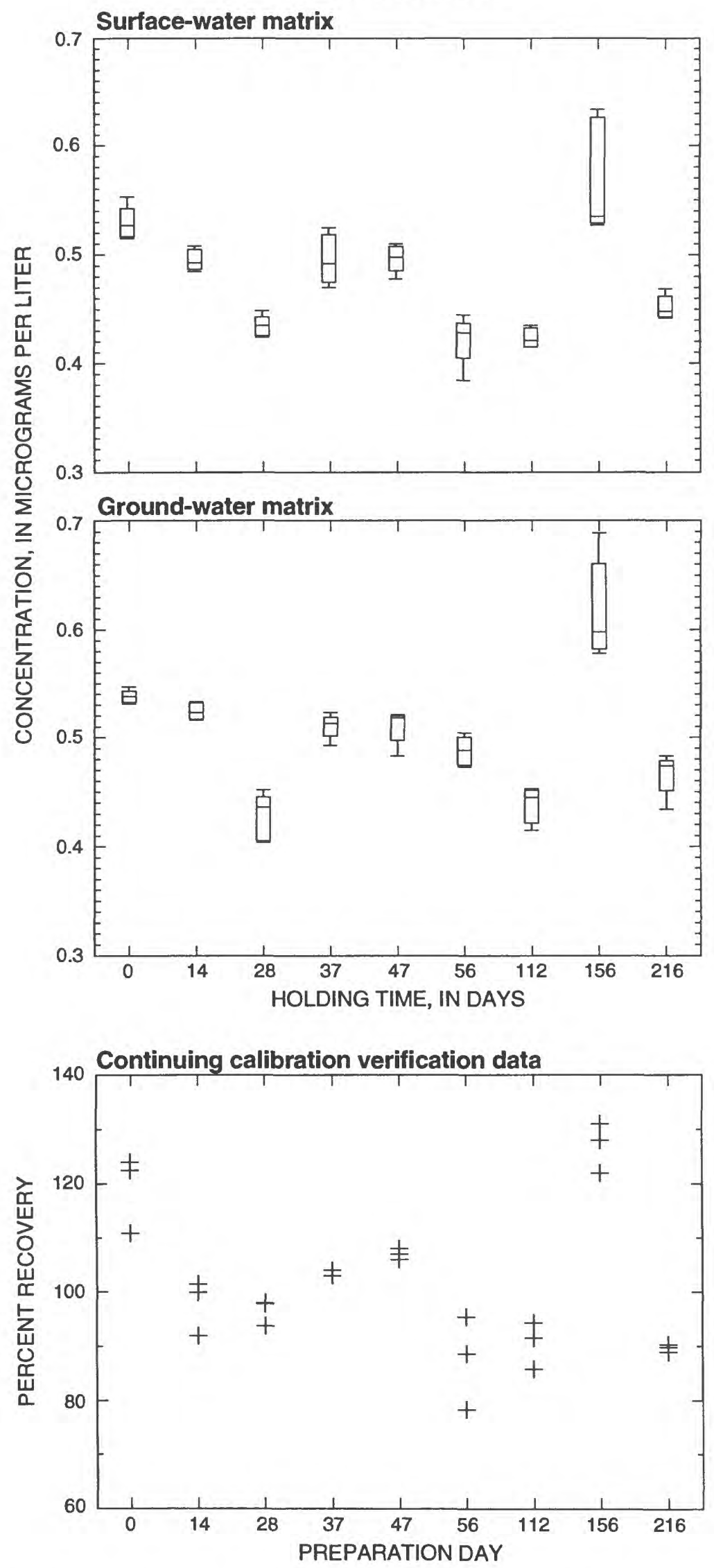
1-Isopropyl-4-methylbenzene
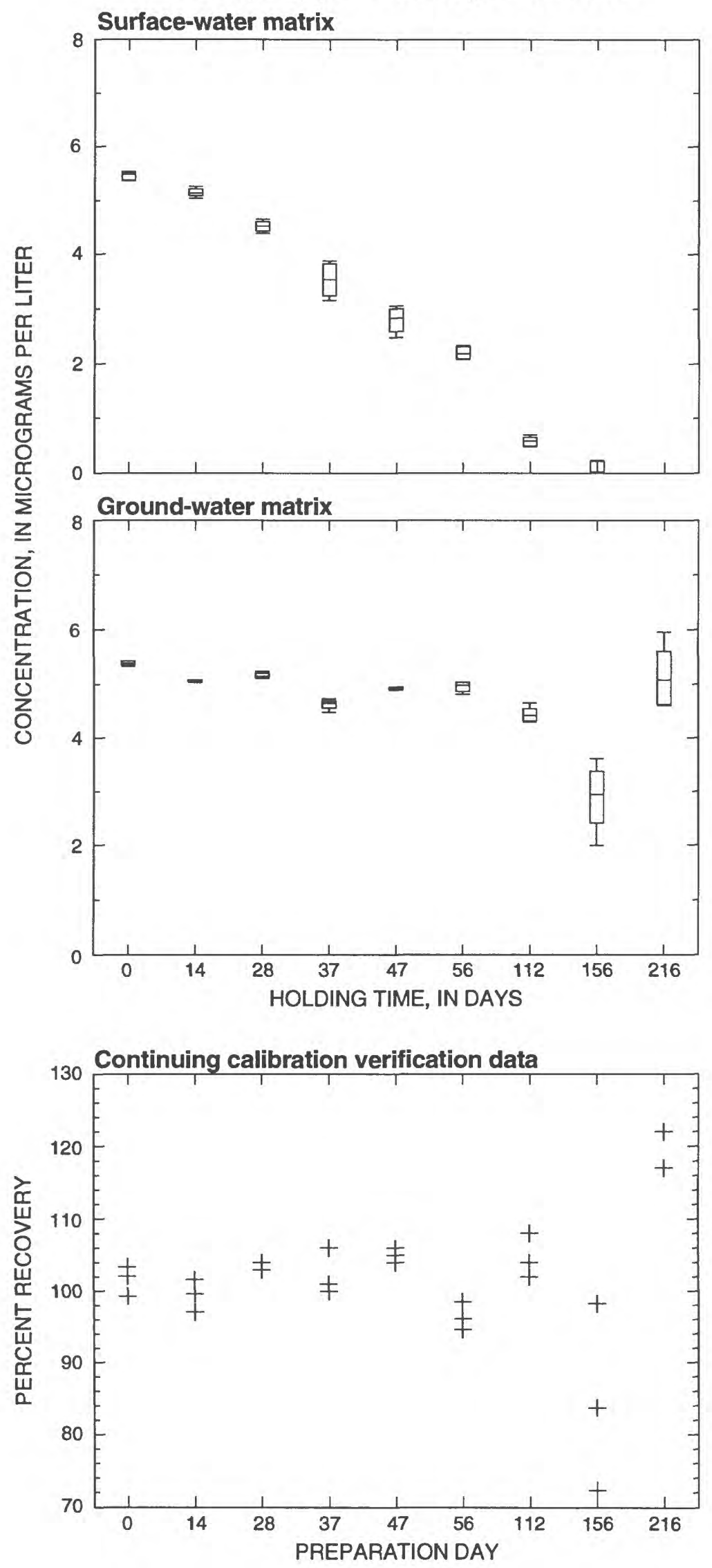
Methyl 2-methyl-2-propenoate
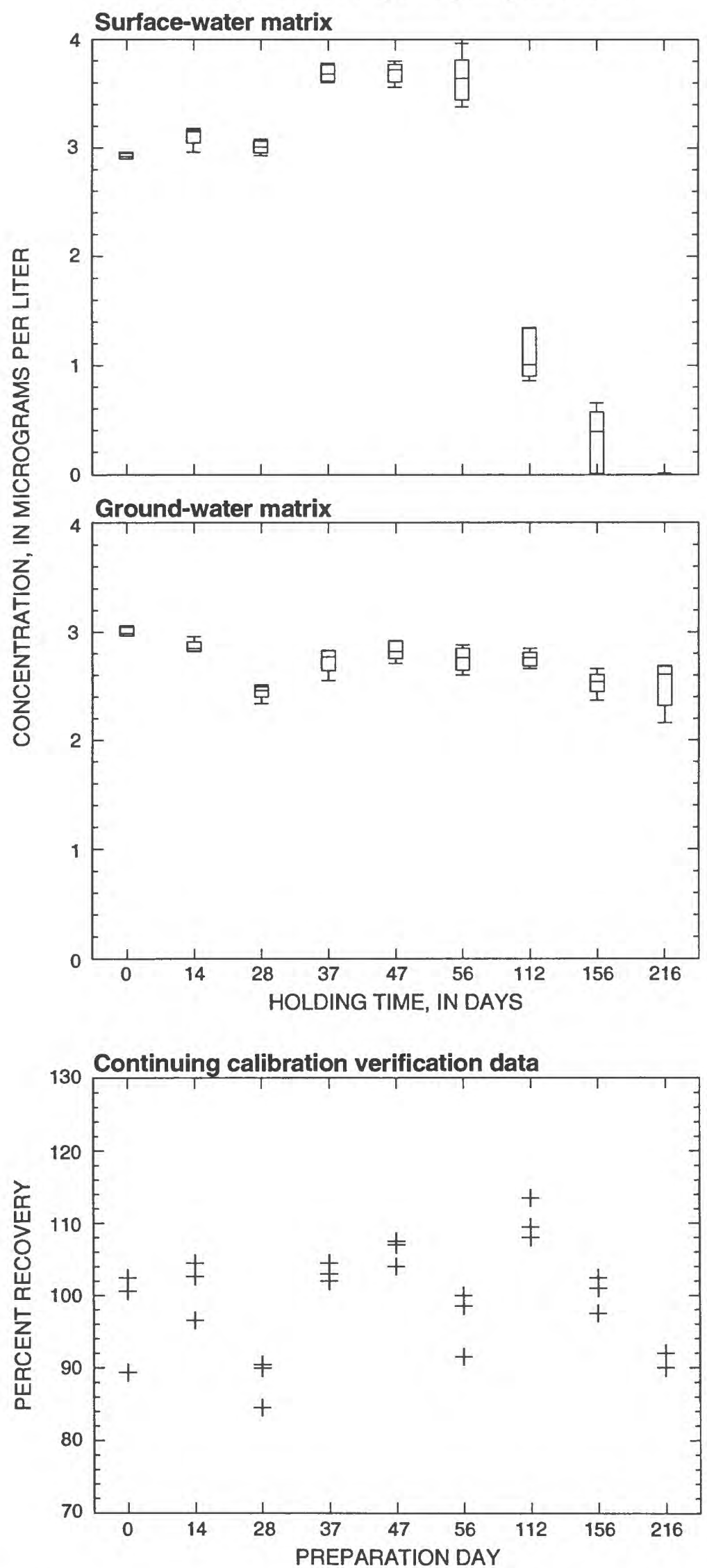
4-Methyl-2-pentanone
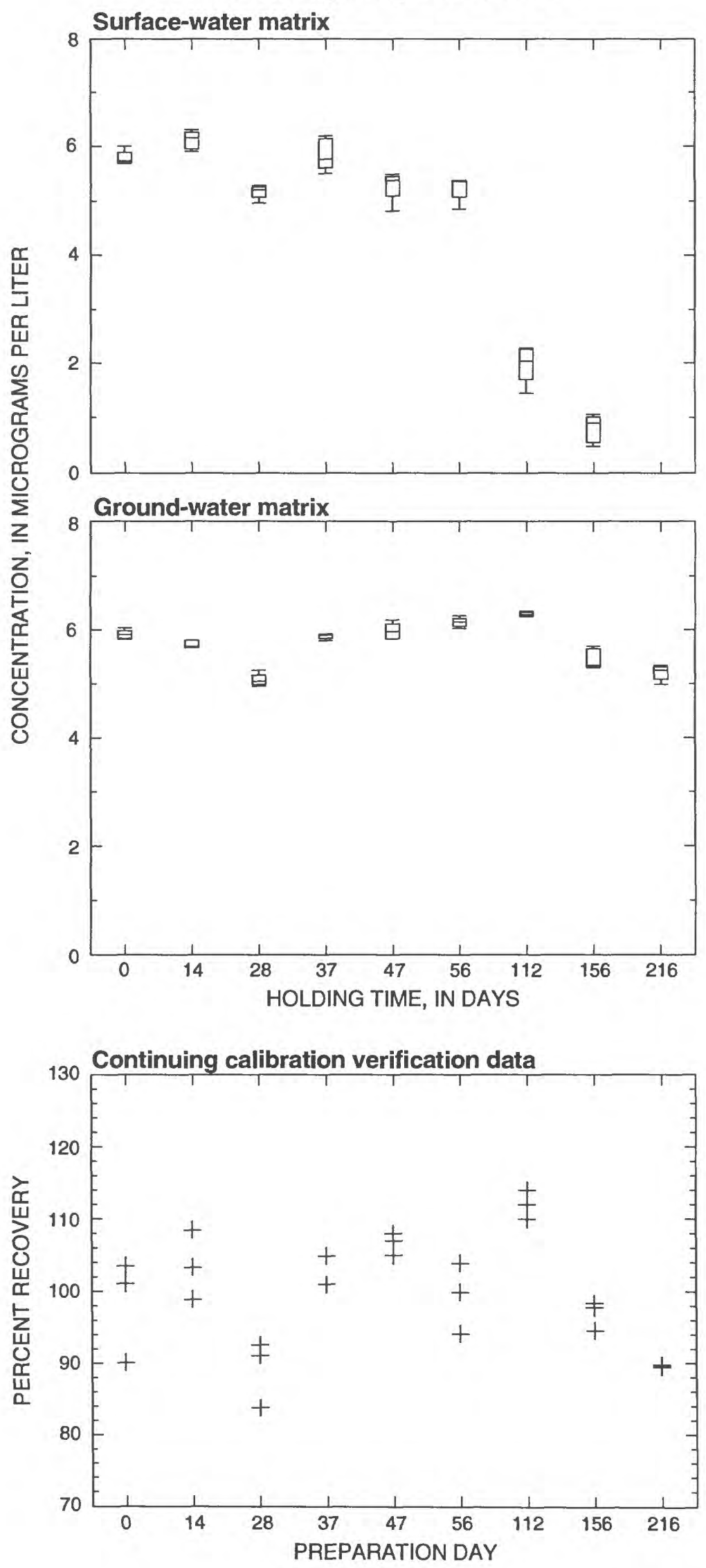
2-Methyl-2-propenenitrile
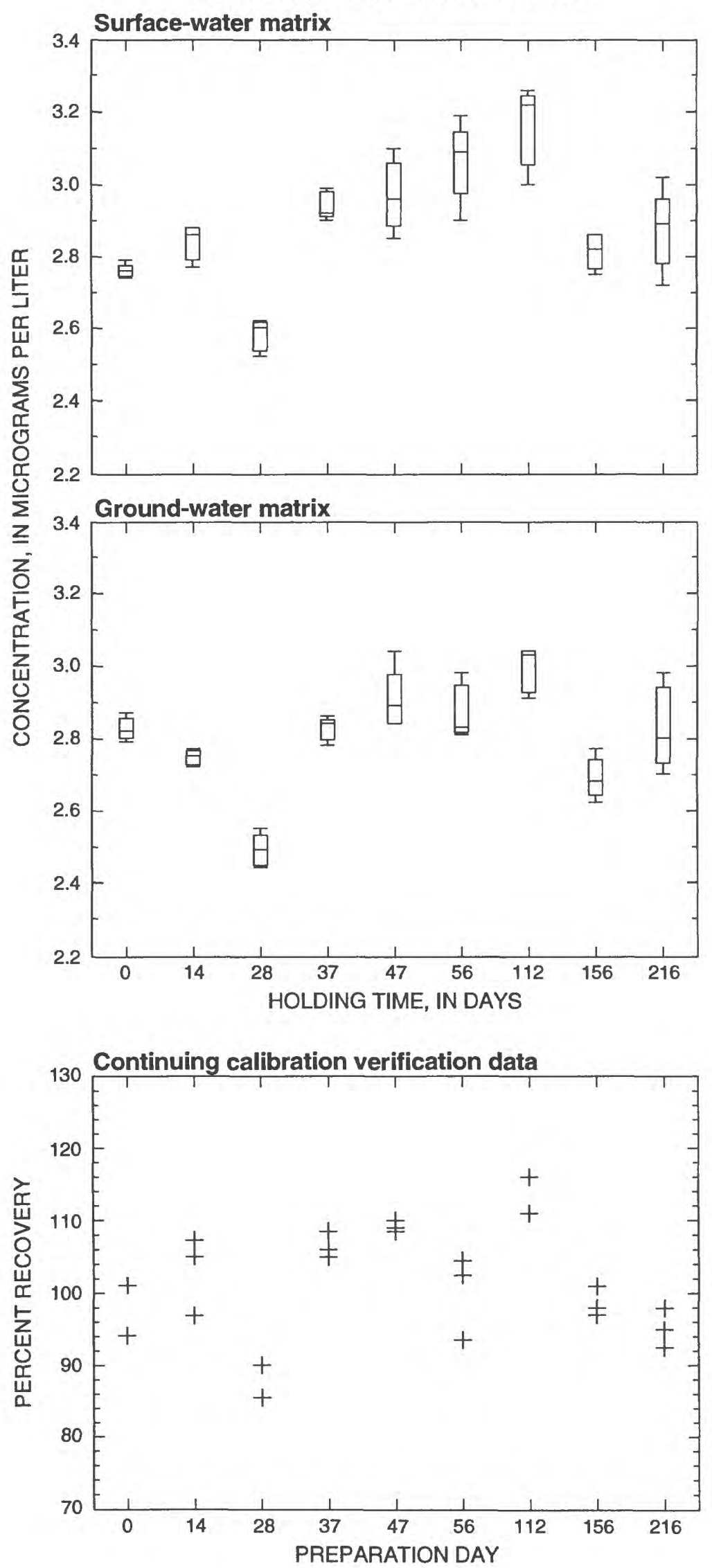
Methyl-2-propenoate
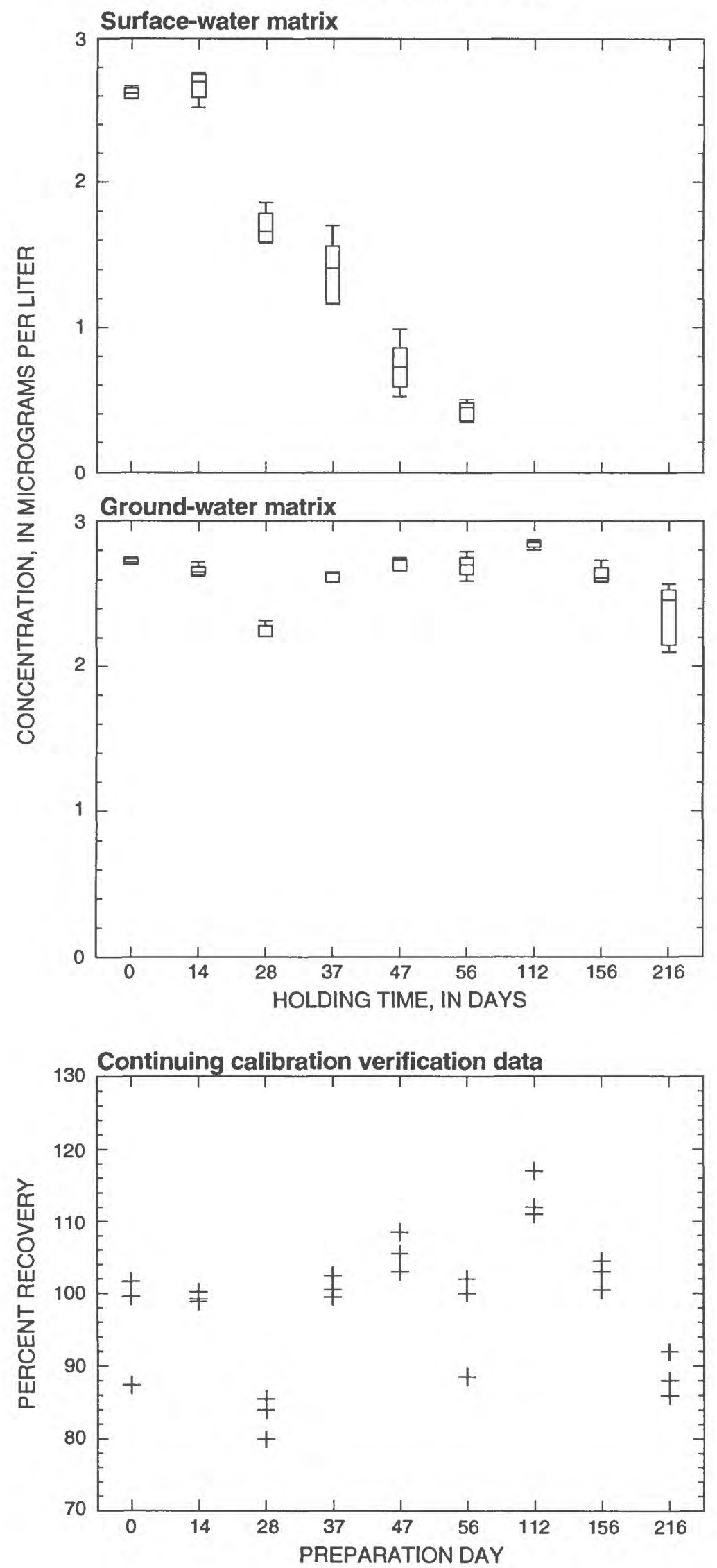
(1-Methylpropyl)benzene
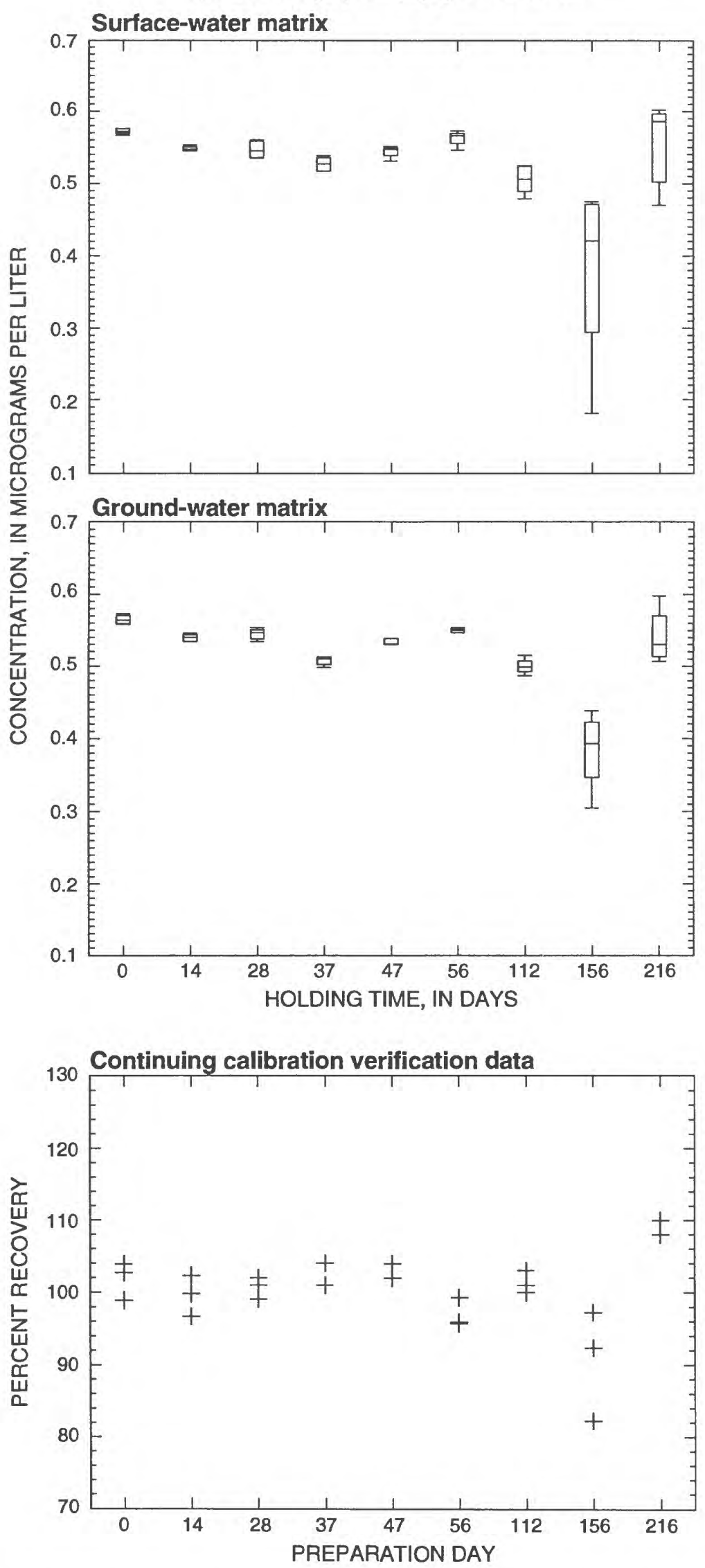


\section{1,1'-Oxybisethane}
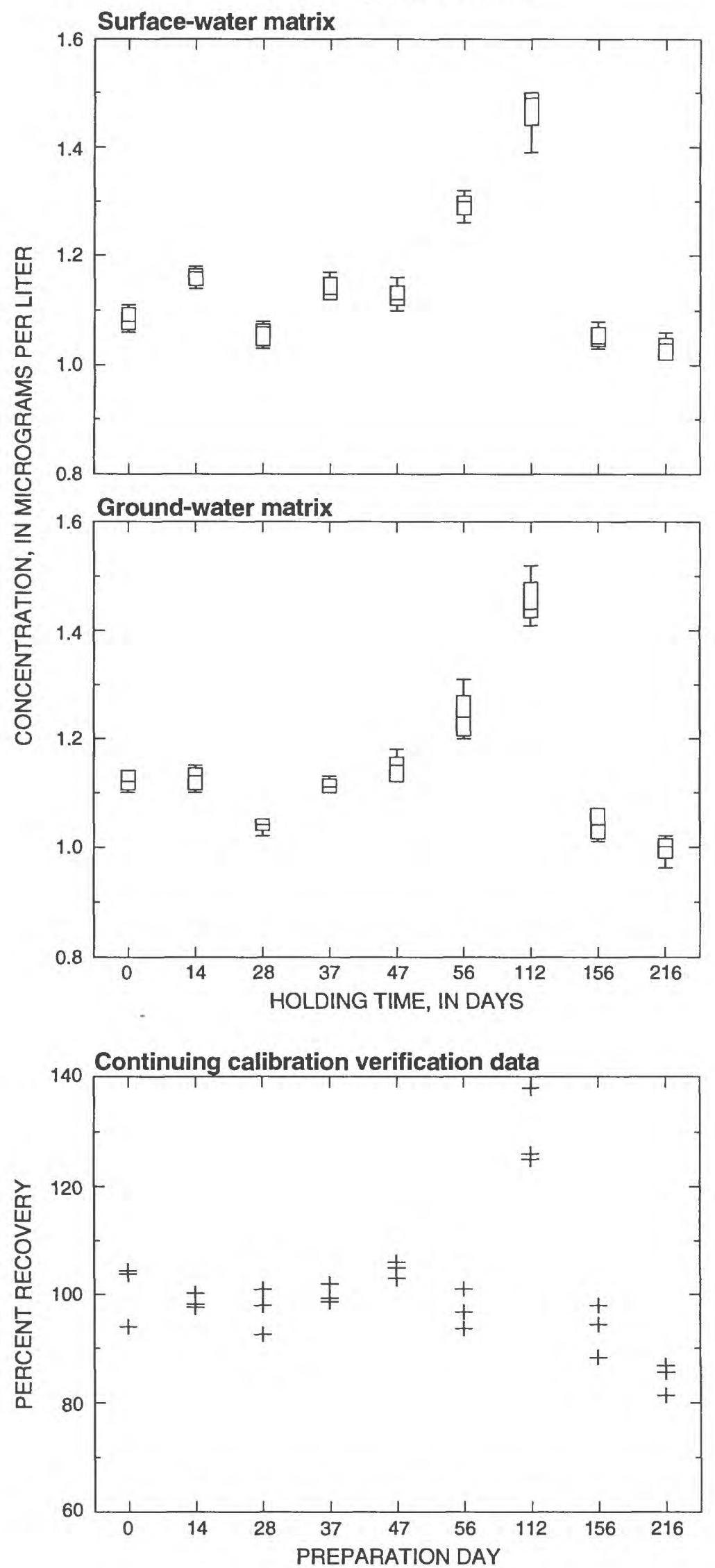


\section{2-Propanone}
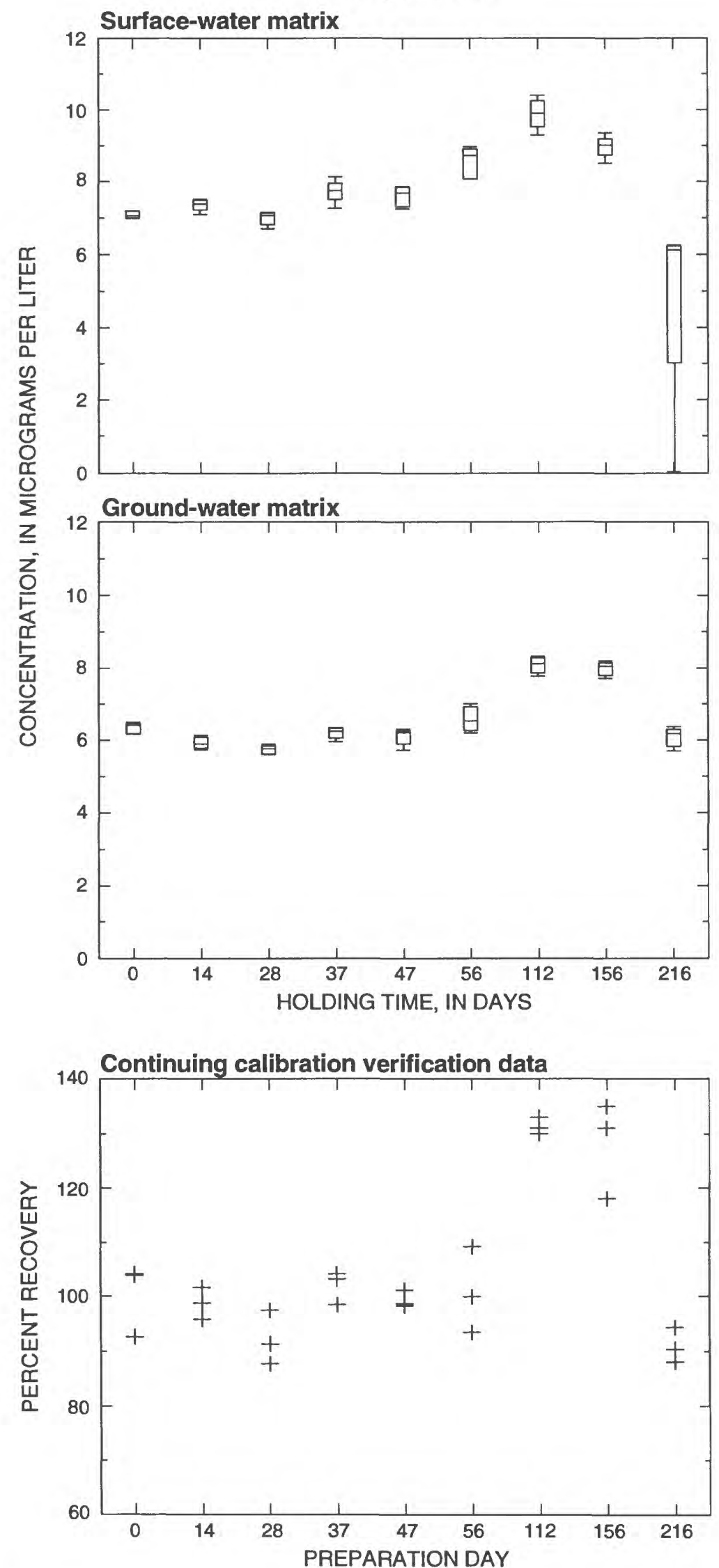
1,1,1,2-Tetrachloroethane
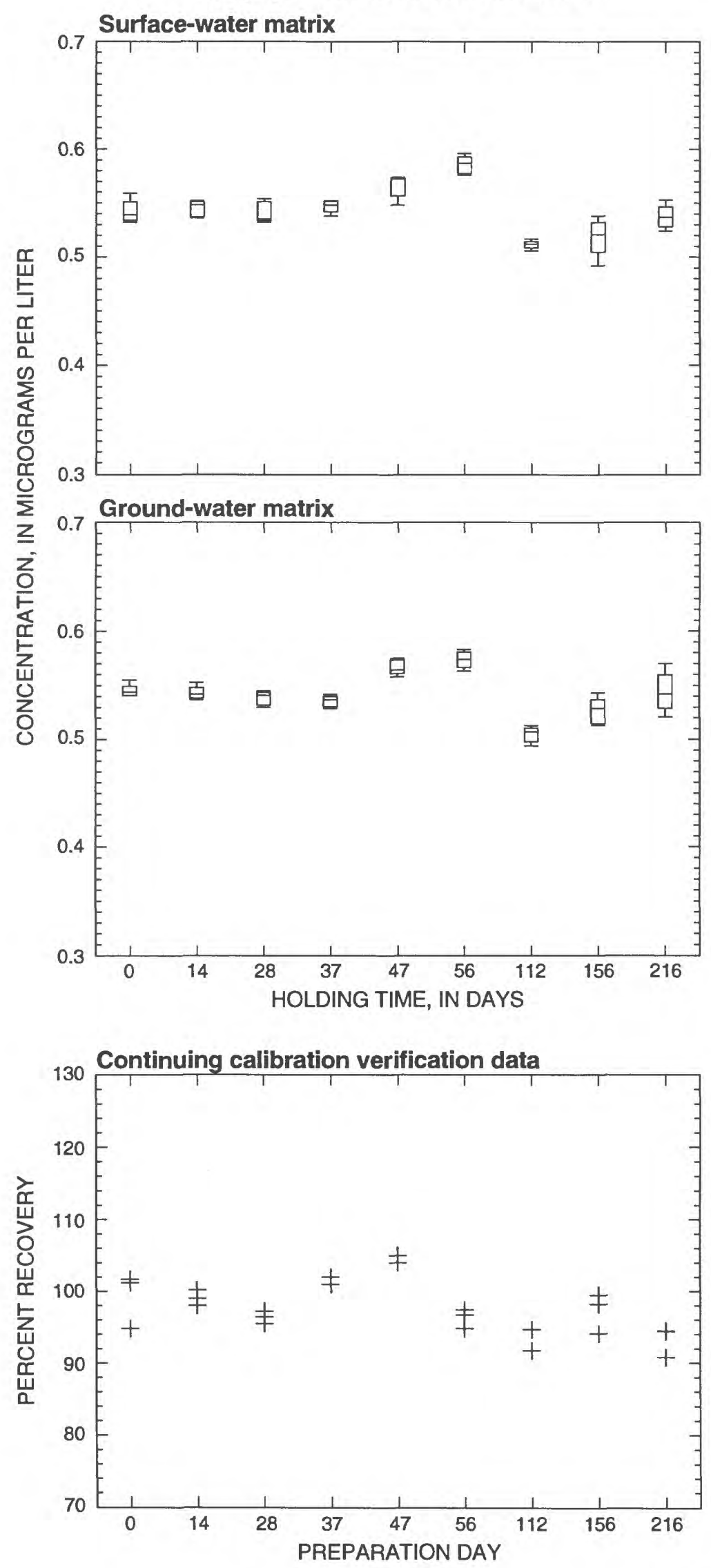

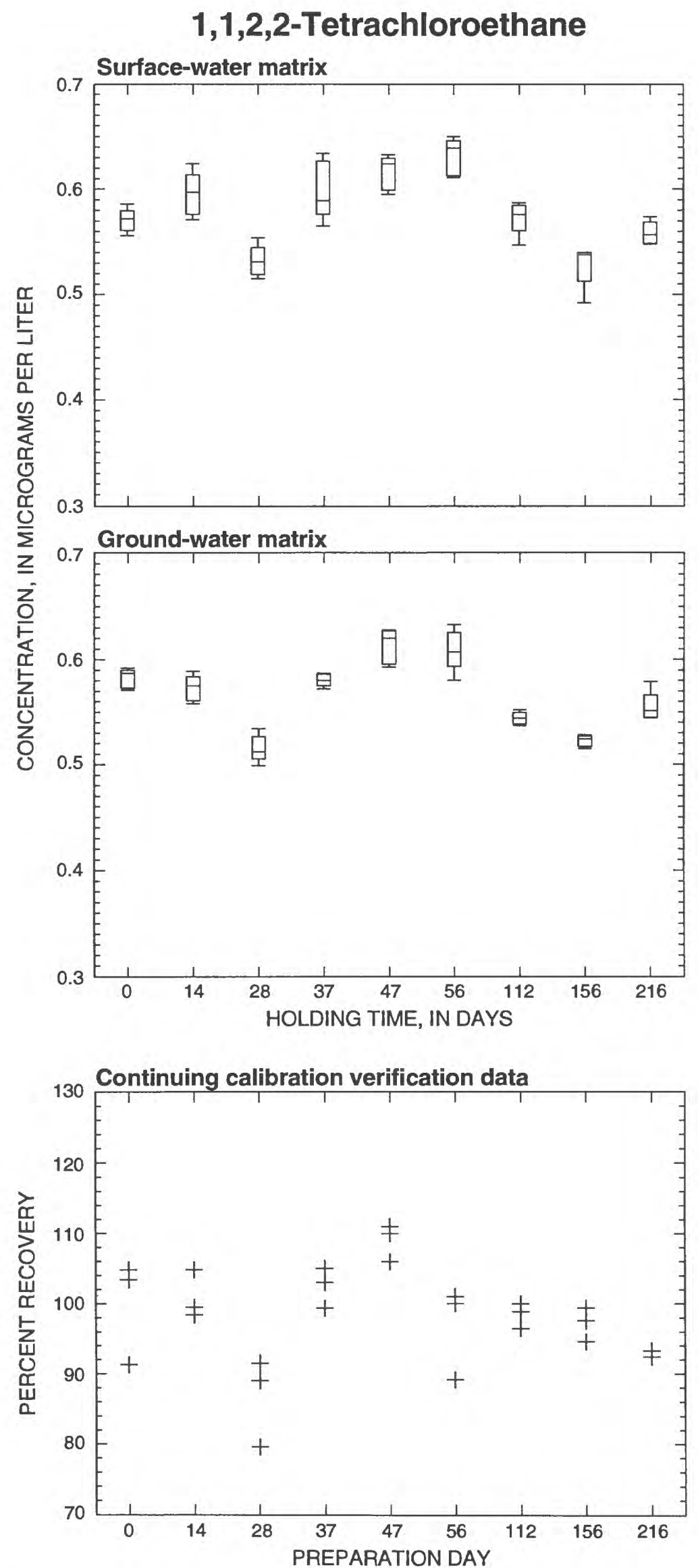
1,2,3,4-Tetramethylbenzene
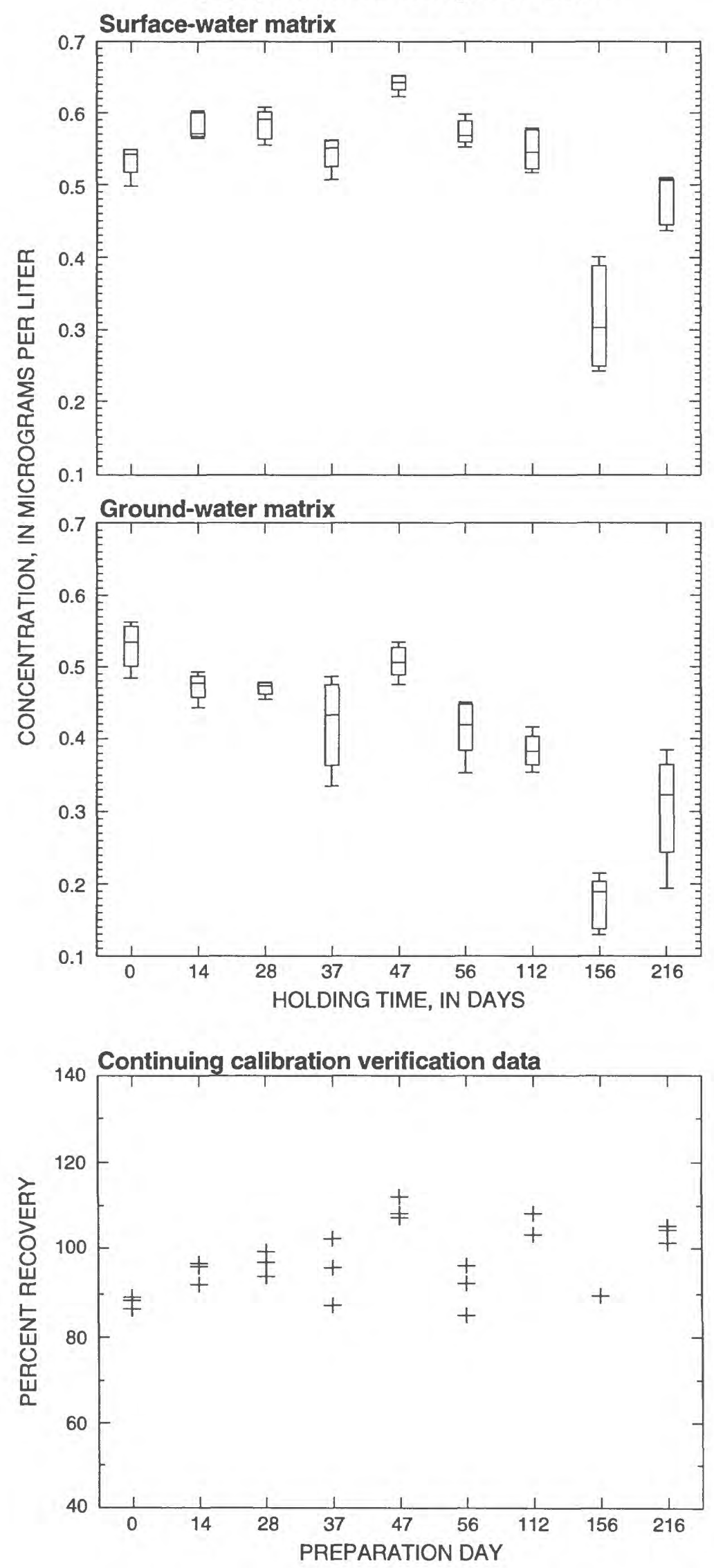
1,2,3,5-Tetramethylbenzene
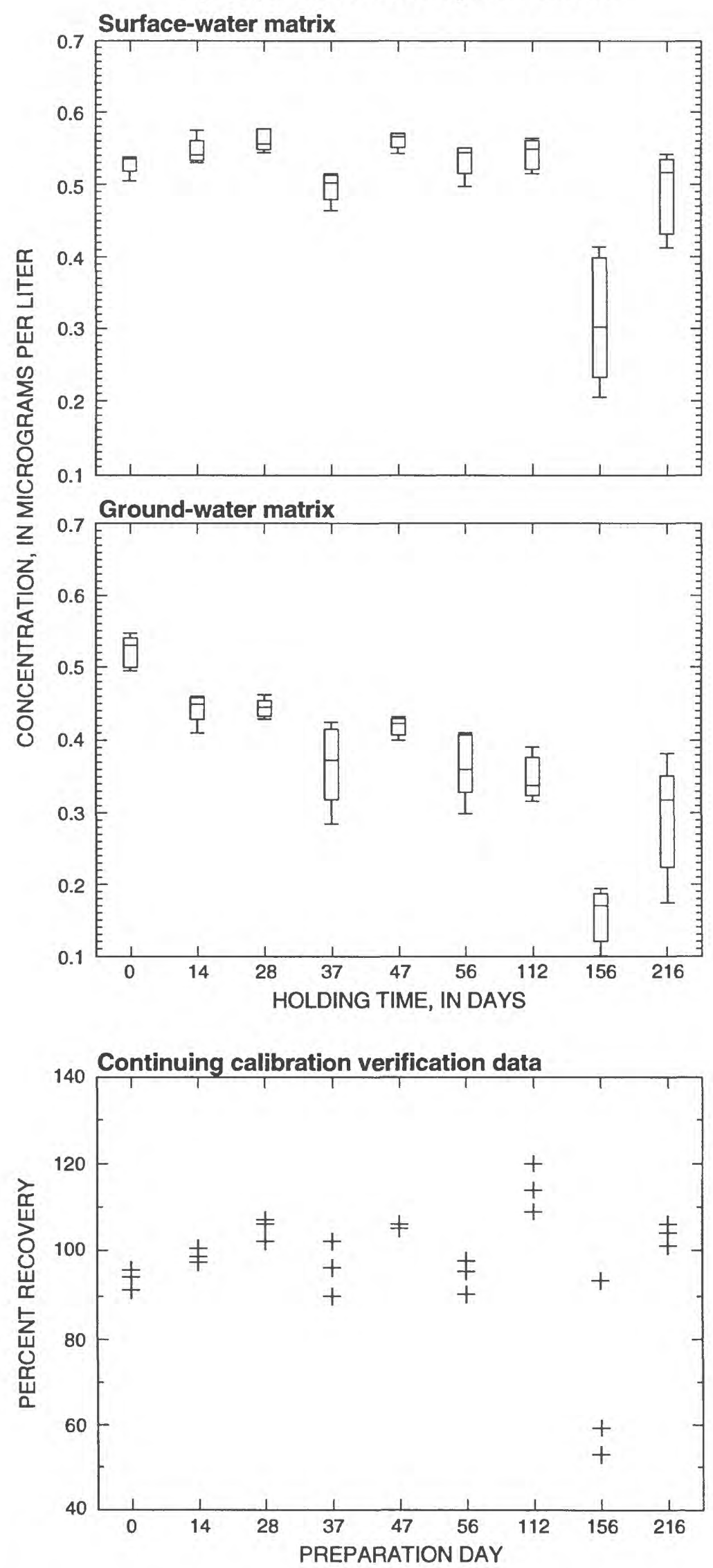


\section{1,2,3-Trimethylbenzene}
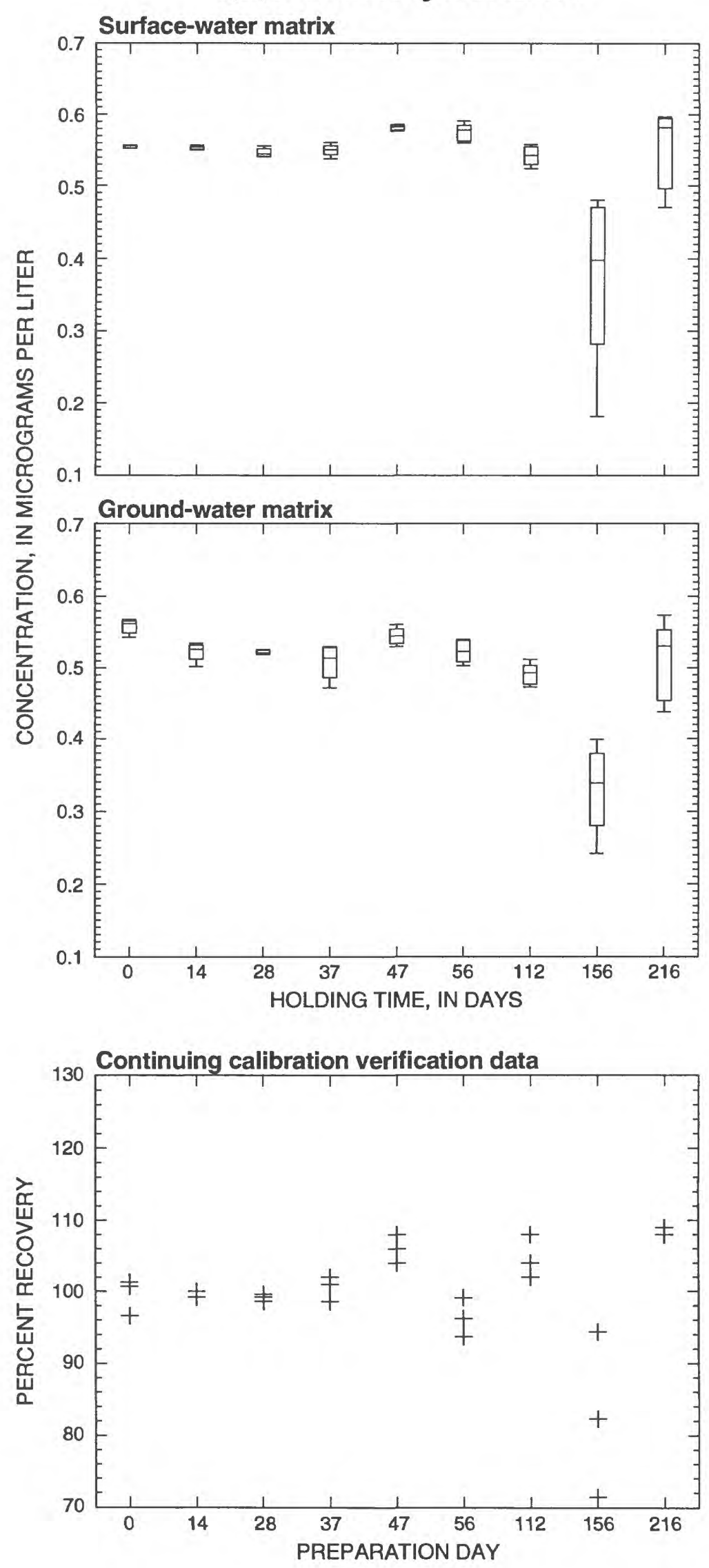
1,3,5-Trimethylbenzene
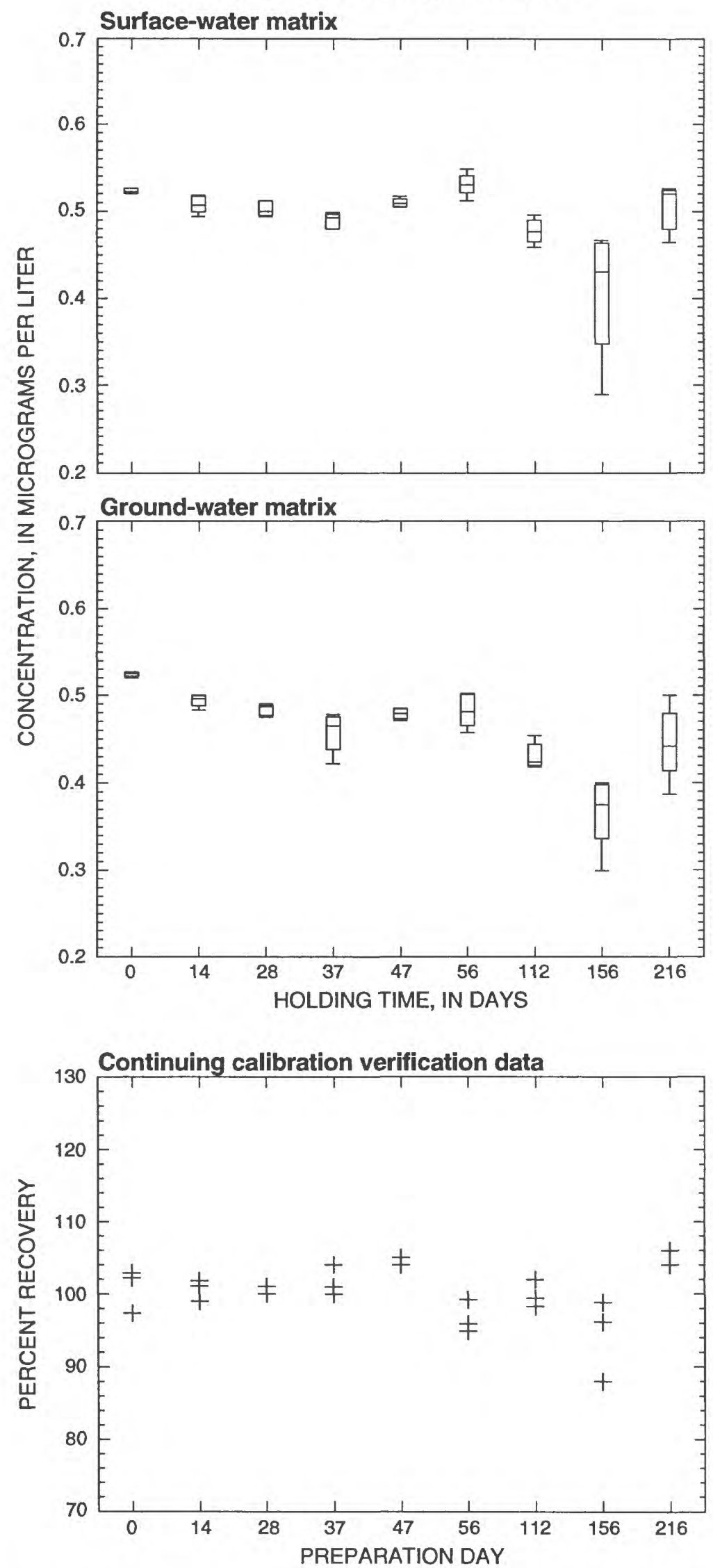
Section C - Analytical Results for Continuing

Calibration Verification Standards 

Table 5. Percent-recovery data for continuing calibration verification standards (CCVS) for day 0 through day 216

[IUPAC, International Union of Pure and Applied Chemistry]

\begin{tabular}{|c|c|c|c|c|}
\hline \multirow{2}{*}{ IUPAC compound name } & \multirow{2}{*}{ Preparation day } & \multicolumn{3}{|c|}{ Replicate CCVS, in percentage of recovery } \\
\hline & & 1 & 2 & 3 \\
\hline \multicolumn{5}{|c|}{ Target analytes } \\
\hline \multirow[t]{9}{*}{ Benzene } & 0 & 101 & 101 & 98.5 \\
\hline & 14 & 100 & 98.2 & 95.6 \\
\hline & 28 & 101 & 101 & 101 \\
\hline & 37 & 103 & 100 & 98.8 \\
\hline & 47 & 102 & 101 & 102 \\
\hline & 56 & 93.0 & 95.4 & 94.3 \\
\hline & 112 & 105 & 105 & 106 \\
\hline & 156 & 101 & 97.9 & 99.8 \\
\hline & 216 & 92.7 & 91.4 & 90.2 \\
\hline \multirow[t]{9}{*}{ Bromodichloromethane } & 0 & 99.4 & 98.4 & 85.6 \\
\hline & 14 & 99.1 & 99.8 & 99.6 \\
\hline & 28 & 90.0 & 90.1 & 90.4 \\
\hline & 37 & 102 & 101 & 103 \\
\hline & 47 & 110 & 110 & 111 \\
\hline & 56 & 93.1 & 99.0 & 94.8 \\
\hline & 112 & 98.7 & 97.1 & 96.3 \\
\hline & 156 & 101 & 95.6 & 99.7 \\
\hline & 216 & 96.1 & 93.1 & 92.1 \\
\hline \multirow[t]{9}{*}{ Bromoethene } & 0 & 100 & 105 & 97.1 \\
\hline & 14 & 97.8 & 93.6 & 93.1 \\
\hline & 28 & 102 & 99.3 & 98.0 \\
\hline & 37 & 105 & 94.7 & 97.3 \\
\hline & 47 & 109 & 102 & 105 \\
\hline & 56 & 95.6 & 90.8 & 95.6 \\
\hline & 112 & 114 & 108 & 108 \\
\hline & 156 & 107 & 102 & 106 \\
\hline & 216 & 80.4 & 76.5 & 78.4 \\
\hline \multirow[t]{9}{*}{ Bromomethane } & 0 & 111 & 119 & 86.9 \\
\hline & 14 & 89.9 & 80.9 & 73.5 \\
\hline & 28 & 95.9 & 83.9 & 87.8 \\
\hline & 37 & 115 & 93.5 & 99.7 \\
\hline & 47 & 111 & 104 & 109 \\
\hline & 56 & 76.6 & 56.6 & 53.7 \\
\hline & 112 & 80.9 & 83.8 & 67.1 \\
\hline & 156 & 102 & 103 & 107 \\
\hline & 216 & 77.9 & 78.0 & 75.2 \\
\hline
\end{tabular}


Table 5. Percent-recovery data for continuing calibration verification standards (CCVS) for day 0 through day 216-Continued

[IUPAC, International Union of Pure and Applied Chemistry]

\begin{tabular}{|c|c|c|c|c|}
\hline \multirow{2}{*}{ IUPAC compound name } & \multirow{2}{*}{ Preparation day } & \multicolumn{3}{|c|}{ Replicate CCVS, in percentage of recovery } \\
\hline & & 1 & 2 & 3 \\
\hline \multicolumn{5}{|c|}{ Target analytes-Continued } \\
\hline \multirow[t]{9}{*}{$n$-Butylbenzene } & 0 & 97.0 & 97.2 & 96.0 \\
\hline & 14 & 101 & 96.7 & 93.3 \\
\hline & 28 & 103 & 102 & 102 \\
\hline & 37 & 103 & 92.6 & 96.7 \\
\hline & 47 & 106 & 104 & 105 \\
\hline & 56 & 93.6 & 93.5 & 93.2 \\
\hline & 112 & 105 & 98.5 & 97.5 \\
\hline & 156 & 63.3 & 53.2 & 92.4 \\
\hline & 216 & 127 & 131 & 131 \\
\hline \multirow[t]{9}{*}{ Chlorobenzene } & 0 & 100 & 101 & 95.4 \\
\hline & 14 & 101 & 100 & 99.1 \\
\hline & 28 & 99.3 & 99.7 & 99.1 \\
\hline & 37 & 102 & 99.6 & 98.8 \\
\hline & 47 & 101 & 102 & 103 \\
\hline & 56 & 94.4 & 99.6 & 96.9 \\
\hline & 112 & 100 & 96.8 & 98.7 \\
\hline & 156 & 98.7 & 95.5 & 98.1 \\
\hline & 216 & 98.4 & 93.8 & 92.4 \\
\hline \multirow[t]{9}{*}{ Chloroethane } & 0 & 93.5 & 99.4 & 92.4 \\
\hline & 14 & 93.9 & 81.8 & 81.3 \\
\hline & 28 & 104 & 93.2 & 103 \\
\hline & 37 & 98.4 & 89.6 & 89.8 \\
\hline & 47 & 102 & 93.5 & 99.4 \\
\hline & 56 & 88.7 & 81.2 & 82.7 \\
\hline & 112 & 116 & 112 & 112 \\
\hline & 156 & 107 & 104 & 105 \\
\hline & 216 & 75.6 & 76.0 & 74.6 \\
\hline \multirow[t]{9}{*}{ Chloroethene } & 0 & 99.6 & 108 & 100 \\
\hline & 14 & 95.3 & 80.3 & 84.8 \\
\hline & 28 & 119 & 104 & 117 \\
\hline & 37 & 101 & 88.8 & 90.0 \\
\hline & 47 & 109 & 95.2 & 103 \\
\hline & 56 & 85.5 & 70.9 & 81.1 \\
\hline & 112 & 114 & 106 & 101 \\
\hline & 156 & 130 & 130 & 134 \\
\hline & 216 & 67.9 & 69.2 & 70.6 \\
\hline
\end{tabular}


Table 5. Percent-recovery data for continuing calibration verification standards (CCVS) for day 0 through day 216-Continued

[IUPAC, International Union of Pure and Applied Chemistry]

\begin{tabular}{|c|c|c|c|c|}
\hline \multirow{2}{*}{ IUPAC compound name } & \multirow{2}{*}{ Preparation day } & \multicolumn{3}{|c|}{ Replicate CCVS, in percentage of recovery } \\
\hline & & 1 & 2 & 3 \\
\hline \multicolumn{5}{|c|}{ Target analytes-Continued } \\
\hline \multirow[t]{9}{*}{ Chloromethane } & 0 & 104 & 115 & 107 \\
\hline & 14 & 87.9 & 72.6 & 76.1 \\
\hline & 28 & 113 & 94.3 & 110 \\
\hline & 37 & 89.9 & 74.8 & 77.7 \\
\hline & 47 & 96.4 & 85.0 & 92.1 \\
\hline & 56 & 82.6 & 79.0 & 89.9 \\
\hline & 112 & 130 & 114 & 124 \\
\hline & 156 & 142 & 147 & 150 \\
\hline & 216 & 63.9 & 64.3 & 66.1 \\
\hline \multirow[t]{9}{*}{ 1,2-Dibromo-3-chloropropane } & 0 & 102 & 106 & 88.2 \\
\hline & 14 & 96.6 & 94.6 & 102 \\
\hline & 28 & 93.3 & 95.3 & 94.4 \\
\hline & 37 & 103 & 112 & 113 \\
\hline & 47 & 118 & 111 & 112 \\
\hline & 56 & 90.8 & 99.1 & 97.5 \\
\hline & 112 & 79.6 & 73.7 & 78.5 \\
\hline & 156 & 86.9 & 87.7 & 89.7 \\
\hline & 216 & 80.2 & 80.9 & 77.8 \\
\hline \multirow[t]{9}{*}{ Dibromochloromethane } & 0 & 102 & 102 & 91.2 \\
\hline & 14 & 98.8 & 101 & 101 \\
\hline & 28 & 86.7 & 89.5 & 86.2 \\
\hline & 37 & 100 & 104 & 104 \\
\hline & 47 & 111 & 113 & 114 \\
\hline & 56 & 93.2 & 98.1 & 95.7 \\
\hline & 112 & 89.8 & 86.0 & 84.6 \\
\hline & 156 & 100 & 92.4 & 96.1 \\
\hline & 216 & 92.8 & 92.9 & 90.7 \\
\hline \multirow[t]{9}{*}{ 1,2-Dibromoethane } & 0 & 101 & 101 & 92.3 \\
\hline & 14 & 98.6 & 102 & 104 \\
\hline & 28 & 93.1 & 95.3 & 95.3 \\
\hline & 37 & 101 & 103 & 105 \\
\hline & 47 & 107 & 105 & 107 \\
\hline & 56 & 93.5 & 101 & 98.4 \\
\hline & 112 & 100 & 94.0 & 96.9 \\
\hline & 156 & 99.7 & 94.7 & 98.9 \\
\hline & 216 & 94.2 & 90.4 & 88.6 \\
\hline
\end{tabular}


Table 5. Percent-recovery data for continuing calibration verification standards (CCVS) for day 0 through day 216-Continued

[IUPAC, International Union of Pure and Applied Chemistry]

\begin{tabular}{|c|c|c|c|c|}
\hline \multirow{2}{*}{ IUPAC compound name } & \multirow{2}{*}{ Preparation day } & \multicolumn{3}{|c|}{ Replicate CCVS, in percentage of recovery } \\
\hline & & 1 & 2 & 3 \\
\hline \multicolumn{5}{|c|}{ Target analytes-Continued } \\
\hline \multirow[t]{9}{*}{ 1,2-Dichlorobenzene } & 0 & 100 & 101 & 93.0 \\
\hline & 14 & 100 & 100 & 100 \\
\hline & 28 & 96.4 & 96.9 & 95.9 \\
\hline & 37 & 102 & 102 & 102 \\
\hline & 47 & 105 & 105 & 104 \\
\hline & 56 & 92.8 & 98.4 & 99.3 \\
\hline & 112 & 91.7 & 86.6 & 87.4 \\
\hline & 156 & 101 & 93.2 & 98.7 \\
\hline & 216 & 97.3 & 96.1 & 95.2 \\
\hline \multirow[t]{9}{*}{ 1,3-Dichlorobenzene } & 0 & 103 & 102 & 95.1 \\
\hline & 14 & 99.8 & 102 & 101 \\
\hline & 28 & 100 & 99.1 & 99.6 \\
\hline & 37 & 103 & 102 & 101 \\
\hline & 47 & 105 & 105 & 105 \\
\hline & 56 & 94.7 & 98.9 & 95.7 \\
\hline & 112 & 92.0 & 87.1 & 87.3 \\
\hline & 156 & 101 & 94.2 & 98.3 \\
\hline & 216 & 100 & 96.2 & 96.2 \\
\hline \multirow[t]{9}{*}{ 1,4-Dichlorobenzene } & 0 & 102 & 102 & 93.9 \\
\hline & 14 & 99.8 & 101 & 99.5 \\
\hline & 28 & 97.5 & 97.1 & 96.5 \\
\hline & 37 & 101 & 100 & 102 \\
\hline & 47 & 104 & 106 & 104 \\
\hline & 56 & 92.4 & 97.3 & 95.8 \\
\hline & 112 & 91.0 & 88.0 & 88.5 \\
\hline & 156 & 99.6 & 90.4 & 96.3 \\
\hline & 216 & 98.0 & 98.5 & 98.5 \\
\hline \multirow[t]{9}{*}{ Dichlorodifluoromethane } & 0 & 99.2 & 118 & 104 \\
\hline & 14 & 85.3 & 65.8 & 72.3 \\
\hline & 28 & 124 & 97.1 & 115 \\
\hline & 37 & 83.0 & 68.3 & 72.0 \\
\hline & 47 & 93.4 & 75.2 & 83.3 \\
\hline & 56 & 77.3 & 58.5 & 70.9 \\
\hline & 112 & 99.1 & 87.3 & 81.0 \\
\hline & 156 & 257 & 250 & 264 \\
\hline & 216 & 59.9 & 54.4 & 57.2 \\
\hline
\end{tabular}


Table 5. Percent-recovery data for continuing calibration verification standards (CCVS) for day 0 through day 216-Continued

[IUPAC, International Union of Pure and Applied Chemistry]

\begin{tabular}{|c|c|c|c|c|}
\hline \multirow{2}{*}{ IUPAC compound name } & \multirow{2}{*}{ Preparation day } & \multicolumn{3}{|c|}{ Replicate CCVS, in percentage of recovery } \\
\hline & & 1 & 2 & 3 \\
\hline \multicolumn{5}{|c|}{ Target analytes-Continued } \\
\hline \multirow[t]{9}{*}{ 1,1-Dichloroethane } & 0 & 102 & 104 & 98.6 \\
\hline & 14 & 103 & 98.2 & 96.6 \\
\hline & 28 & 101 & 98.7 & 101 \\
\hline & 37 & 104 & 98.3 & 97.5 \\
\hline & 47 & 101 & 100 & 101 \\
\hline & 56 & 95.6 & 97.2 & 94.2 \\
\hline & 112 & 118 & 114 & 115 \\
\hline & 156 & 103 & 99.6 & 102 \\
\hline & 216 & 93.3 & 91.6 & 90.2 \\
\hline \multirow[t]{9}{*}{ 1,2-Dichloroethane } & 0 & 100 & 103 & 94.9 \\
\hline & 14 & 102 & 99.9 & 99.4 \\
\hline & 28 & 92.0 & 94.9 & 96.3 \\
\hline & 37 & 103 & 100 & 100 \\
\hline & 47 & 101 & 102 & 101 \\
\hline & 56 & 94.0 & 97.1 & 97.2 \\
\hline & 112 & 124 & 119 & 121 \\
\hline & 156 & 102 & 97.2 & 99.6 \\
\hline & 216 & 93.6 & 92.6 & 91.2 \\
\hline \multirow[t]{9}{*}{ 1,1-Dichloroethene } & 0 & 98.1 & 104 & 97.8 \\
\hline & 14 & 104 & 97.4 & 96.6 \\
\hline & 28 & 119 & 108 & 114 \\
\hline & 37 & 105 & 98.4 & 99.3 \\
\hline & 47 & 110 & 104 & 110 \\
\hline & 56 & 98.0 & 99.2 & 99.3 \\
\hline & 112 & 107 & 100 & 101 \\
\hline & 156 & 98.1 & 92.3 & 98.5 \\
\hline & 216 & 84.0 & 82.3 & 85.8 \\
\hline \multirow[t]{9}{*}{ cis-1,2-Dichloroethene } & 0 & 101 & 101 & 93.1 \\
\hline & 14 & 102 & 101 & 99.5 \\
\hline & 28 & 104 & 103 & 104 \\
\hline & 37 & 103 & 102 & 101 \\
\hline & 47 & 104 & 103 & 104 \\
\hline & 56 & 94.7 & 99.7 & 97.3 \\
\hline & 112 & 100 & 98.1 & 98.7 \\
\hline & 156 & 102 & 100 & 101 \\
\hline & 216 & 94.6 & 93.3 & 91.4 \\
\hline
\end{tabular}


Table 5. Percent-recovery data for continuing calibration verification standards (CCVS) for day 0 through day 216-Continued

[IUPAC, International Union of Pure and Applied Chemistry]

\begin{tabular}{|c|c|c|c|c|}
\hline \multirow{2}{*}{ IUPAC compound name } & \multirow{2}{*}{ Preparation day } & \multicolumn{3}{|c|}{ Replicate CCVS, in percentage of recovery } \\
\hline & & 1 & 2 & 3 \\
\hline \multicolumn{5}{|c|}{ Target analytes-Continued } \\
\hline \multirow[t]{9}{*}{ trans-1,2-Dichloroethene } & 0 & 101 & 102 & 96.2 \\
\hline & 14 & 102 & 97.2 & 97.4 \\
\hline & 28 & 109 & 105 & 106 \\
\hline & 37 & 102 & 99.3 & 98.5 \\
\hline & 47 & 104 & 104 & 102 \\
\hline & 56 & 95.5 & 98.3 & 94.1 \\
\hline & 112 & 97.1 & 94.4 & 95.6 \\
\hline & 156 & 105 & 101 & 103 \\
\hline & 216 & 93.3 & 87.8 & 85.5 \\
\hline \multirow[t]{9}{*}{ Dichloromethane } & 0 & 100 & 99.9 & 94.7 \\
\hline & 14 & 98.3 & 95.5 & 96.9 \\
\hline & 28 & 98.9 & 95.3 & 99.1 \\
\hline & 37 & 100 & 99.2 & 97.3 \\
\hline & 47 & 102 & 100 & 102 \\
\hline & 56 & 94.4 & 96.8 & 95.4 \\
\hline & 112 & 98.0 & 95.8 & 95.7 \\
\hline & 156 & 99.9 & 96.8 & 97.5 \\
\hline & 216 & 92.2 & 87.3 & 86.5 \\
\hline \multirow[t]{9}{*}{ 1,2-Dichloropropane } & 0 & 103 & 103 & 97.1 \\
\hline & 14 & 98.6 & 98.8 & 96.6 \\
\hline & 28 & 94.3 & 94.2 & 97.6 \\
\hline & 37 & 103 & 97.8 & 98.6 \\
\hline & 47 & 100 & 100 & 101 \\
\hline & 56 & 96.0 & 96.9 & 96.4 \\
\hline & 112 & 118 & 115 & 118 \\
\hline & 156 & 101 & 96.8 & 100 \\
\hline & 216 & 95.7 & 93.4 & 93.8 \\
\hline \multirow[t]{9}{*}{ cis-1,3-Dichloropropene } & 0 & 97.6 & 102 & 93.9 \\
\hline & 14 & 97.5 & 99.1 & 98.1 \\
\hline & 28 & 96.9 & 95.8 & 93.9 \\
\hline & 37 & 99.4 & 101 & 104 \\
\hline & 47 & 107 & 103 & 101 \\
\hline & 56 & 94.1 & 98.4 & 97.0 \\
\hline & 112 & 93.5 & 91.0 & 91.2 \\
\hline & 156 & 101 & 96.6 & 105 \\
\hline & 216 & 91.5 & 91.4 & 93.1 \\
\hline
\end{tabular}


Table 5. Percent-recovery data for continuing calibration verification standards (CCVS) for day 0 through day 216-Continued

[IUPAC, International Union of Pure and Applied Chemistry]

\begin{tabular}{|c|c|c|c|c|}
\hline \multirow{2}{*}{ IUPAC compound name } & \multirow{2}{*}{ Preparation day } & \multicolumn{3}{|c|}{ Replicate CCVS, in percentage of recovery } \\
\hline & & 1 & 2 & 3 \\
\hline \multicolumn{5}{|c|}{ Target analytes-Continued } \\
\hline \multirow[t]{9}{*}{ trans-1,3-Dichloropropene } & 0 & 101 & 98.8 & 93.0 \\
\hline & 14 & 99.3 & 103 & 100 \\
\hline & 28 & 90.2 & 95.1 & 88.1 \\
\hline & 37 & 101 & 101 & 106 \\
\hline & 47 & 105 & 106 & 109 \\
\hline & 56 & 89.1 & 95.3 & 92.4 \\
\hline & 112 & 91.4 & 82.8 & 86.4 \\
\hline & 156 & 99.8 & 96.2 & 97.9 \\
\hline & 216 & 90.2 & 87.9 & 88.7 \\
\hline \multirow[t]{9}{*}{ 1,2-Dimethylbenzene } & 0 & 102 & 101 & 95.5 \\
\hline & 14 & 100 & 102 & 99.4 \\
\hline & 28 & 98.8 & 98.5 & 97.0 \\
\hline & 37 & 101 & 101 & 101 \\
\hline & 47 & 102 & 104 & 102 \\
\hline & 56 & 95.2 & 103 & 96.7 \\
\hline & 112 & 101 & 98.4 & 100 \\
\hline & 156 & 101 & 95.3 & 101 \\
\hline & 216 & 98.5 & 94.9 & 91.8 \\
\hline \multirow[t]{9}{*}{ 1,3-Dimethylbenzene and 1,4-Dimethylbenzene } & 0 & 102 & 102 & 97.2 \\
\hline & 14 & 101 & 101 & 98.6 \\
\hline & 28 & 100 & 100 & 99.0 \\
\hline & 37 & 103 & 101 & 100 \\
\hline & 47 & 102 & 104 & 104 \\
\hline & 56 & 95.5 & 101 & 95.5 \\
\hline & 112 & 102 & 98.5 & 99.5 \\
\hline & 156 & 104 & 99.0 & 102 \\
\hline & 216 & 100 & 95.5 & 95.5 \\
\hline \multirow[t]{9}{*}{ Ethenylbenzene } & 0 & 103 & 103 & 96.0 \\
\hline & 14 & 102 & 102 & 99.7 \\
\hline & 28 & 96.0 & 97.6 & 97.0 \\
\hline & 37 & 104 & 101 & 101 \\
\hline & 47 & 104 & 104 & 104 \\
\hline & 56 & 94.5 & 99.7 & 96.6 \\
\hline & 112 & 100 & 94.8 & 96.4 \\
\hline & 156 & 102 & 96.2 & 100 \\
\hline & 216 & 97.8 & 94.7 & 93.2 \\
\hline
\end{tabular}


Table 5. Percent-recovery data for continuing calibration verification standards (CCVS) for day 0 through day 216 - Continued

[IUPAC, International Union of Pure and Applied Chemistry]

\begin{tabular}{|c|c|c|c|c|}
\hline \multirow{2}{*}{ IUPAC compound name } & \multirow{2}{*}{ Preparation day } & \multicolumn{3}{|c|}{ Replicate CCVS, in percentage of recovery } \\
\hline & & 1 & 2 & 3 \\
\hline \multicolumn{5}{|c|}{ Target analytes - Continued } \\
\hline \multirow[t]{9}{*}{ 2-Ethoxy-2-methylpropane } & 0 & 97.1 & 102 & 90.8 \\
\hline & 14 & 99.0 & 98.3 & 101 \\
\hline & 28 & 88.7 & 91.0 & 92.7 \\
\hline & 37 & 100 & 102 & 103 \\
\hline & 47 & 105 & 105 & 103 \\
\hline & 56 & 92.8 & 97.6 & 99.6 \\
\hline & 112 & 120 & 115 & 118 \\
\hline & 156 & 102 & 95.0 & 98.6 \\
\hline & 216 & 91.4 & 89.4 & 89.4 \\
\hline \multirow[t]{9}{*}{ Ethylbenzene } & 0 & 104 & 102 & 96.1 \\
\hline & 14 & 102 & 100 & 97.9 \\
\hline & 28 & 99.7 & 98.8 & 98.6 \\
\hline & 37 & 103 & 102 & 101 \\
\hline & 47 & 103 & 104 & 103 \\
\hline & 56 & 95.1 & 101 & 96.0 \\
\hline & 112 & 101 & 99.1 & 98.9 \\
\hline & 156 & 101 & 95.6 & 101 \\
\hline & 216 & 97.3 & 95.4 & 95.2 \\
\hline \multirow[t]{9}{*}{ 1,1,2,3,4,4-Hexachloro-1,3-butadiene } & 0 & 102 & 105 & 97.7 \\
\hline & 14 & 99.7 & 100 & 97.9 \\
\hline & 28 & 109 & 105 & 106 \\
\hline & 37 & 102 & 101 & 98.7 \\
\hline & 47 & 106 & 104 & 107 \\
\hline & 56 & 95.1 & 98.2 & 98.3 \\
\hline & 112 & 83.1 & 82.3 & 78.7 \\
\hline & 156 & 90.2 & 83.5 & 96.3 \\
\hline & 216 & 104 & 106 & 109 \\
\hline \multirow[t]{9}{*}{ 1,1,1,2,2,2-Hexachloroethane } & 0 & 104 & 103 & 94.9 \\
\hline & 14 & 101 & 102 & 99.7 \\
\hline & 28 & 103 & 102 & 102 \\
\hline & 37 & 99.6 & 108 & 102 \\
\hline & 47 & 112 & 114 & 114 \\
\hline & 56 & 94.1 & 102 & 97.9 \\
\hline & 112 & 90.7 & 87.6 & 88.6 \\
\hline & 156 & 96.3 & 87.9 & 94.1 \\
\hline & 216 & 88.0 & 86.8 & 89.5 \\
\hline
\end{tabular}


Table 5. Percent-recovery data for continuing calibration verification standards (CCVS) for day 0 through day 216-Continued

[IUPAC, International Union of Pure and Applied Chemistry]

\begin{tabular}{|c|c|c|c|c|}
\hline \multirow{2}{*}{ IUPAC compound name } & \multirow{2}{*}{ Preparation day } & \multicolumn{3}{|c|}{ Replicate CCVS, in percentage of recovery } \\
\hline & & 1 & 2 & 3 \\
\hline \multicolumn{5}{|c|}{ Target analytes-Continued } \\
\hline \multirow[t]{9}{*}{ 2-Methoxy-2-methylbutane } & 0 & 98.1 & 99.8 & 90.6 \\
\hline & 14 & 97.5 & 102 & 104 \\
\hline & 28 & 88.2 & 91.7 & 92.6 \\
\hline & 37 & 100 & 103 & 102 \\
\hline & 47 & 105 & 106 & 105 \\
\hline & 56 & 91.7 & 99.2 & 102 \\
\hline & 112 & 112 & 107 & 112 \\
\hline & 156 & 101 & 97.0 & 98.6 \\
\hline & 216 & 89.0 & 89.9 & 87.6 \\
\hline \multirow[t]{9}{*}{ 2-Methoxy-2-methylpropane } & 0 & 98.8 & 101 & 89.9 \\
\hline & 14 & 98.4 & 100 & 104 \\
\hline & 28 & 91.0 & 93.3 & 95.0 \\
\hline & 37 & 102 & 102 & 105 \\
\hline & 47 & 106 & 106 & 109 \\
\hline & 56 & 94.6 & 98.8 & 102 \\
\hline & 112 & 111 & 106 & 109 \\
\hline & 156 & 103 & 96.6 & 98.6 \\
\hline & 216 & 86.5 & 85.9 & 85.8 \\
\hline \multirow[t]{9}{*}{ Methylbenzene } & 0 & 104 & 101 & 96.8 \\
\hline & 14 & 100 & 97.2 & 96.0 \\
\hline & 28 & 98.7 & 99.5 & 99.5 \\
\hline & 37 & 102 & 100 & 99.7 \\
\hline & 47 & 101 & 100 & 104 \\
\hline & 56 & 91.3 & 97.2 & 93.6 \\
\hline & 112 & 101 & 100 & 100 \\
\hline & 156 & 98.2 & 95.3 & 98.0 \\
\hline & 216 & 96.7 & 95.3 & 92.6 \\
\hline \multirow[t]{9}{*}{ (1-Methylethyl)benzene } & 0 & 102 & 102 & 97.3 \\
\hline & 14 & 102 & 101 & 98.2 \\
\hline & 28 & 101 & 99.6 & 99.6 \\
\hline & 37 & 104 & 102 & 100 \\
\hline & 47 & 102 & 103 & 103 \\
\hline & 56 & 96.5 & 101 & 95.0 \\
\hline & 112 & 103 & 99.6 & 100 \\
\hline & 156 & 100 & 97.0 & 98.8 \\
\hline & 216 & 101 & 97.8 & 94.9 \\
\hline
\end{tabular}


Table 5. Percent-recovery data for continuing calibration verification standards (CCVS) for day 0 through day 216-Continued

[IUPAC, International Union of Pure and Applied Chemistry]

\begin{tabular}{|c|c|c|c|c|}
\hline \multirow{2}{*}{ IUPAC compound name } & \multirow{2}{*}{ Preparation day } & \multicolumn{3}{|c|}{ Replicate CCVS, in percentage of recovery } \\
\hline & & 1 & 2 & 3 \\
\hline \multicolumn{5}{|c|}{ Target analytes-Continued } \\
\hline \multirow[t]{9}{*}{ Naphthalene } & 0 & 88.5 & 91.2 & 81.0 \\
\hline & 14 & 112 & 115 & 117 \\
\hline & 28 & 97.2 & 106 & 109 \\
\hline & 37 & 116 & 99.6 & 114 \\
\hline & 47 & 140 & 135 & 138 \\
\hline & 56 & 101 & 98.0 & 116 \\
\hline & 112 & 88.4 & 86.6 & 90.0 \\
\hline & 156 & 50.1 & 45.3 & 89.9 \\
\hline & 216 & 90.7 & 98.3 & 98.9 \\
\hline \multirow[t]{9}{*}{ 2,2'-Oxybis[propane] } & 0 & 97.9 & 98.8 & 95.4 \\
\hline & 14 & 100 & 99.5 & 98.8 \\
\hline & 28 & 92.3 & 93.8 & 94.4 \\
\hline & 37 & 103 & 101 & 102 \\
\hline & 47 & 103 & 102 & 104 \\
\hline & 56 & 93.0 & 102 & 102 \\
\hline & 112 & 116 & 115 & 113 \\
\hline & 156 & 103 & 98.6 & 101 \\
\hline & 216 & 92.2 & 95.4 & 93.6 \\
\hline \multirow[t]{9}{*}{ 2-Propenal } & 0 & 124 & 131 & 97.1 \\
\hline & 14 & 98.8 & 101 & 108 \\
\hline & 28 & 70.4 & 77.0 & 79.0 \\
\hline & 37 & 109 & 119 & 121 \\
\hline & 47 & 135 & 137 & 141 \\
\hline & 56 & 97.8 & 108 & 110 \\
\hline & 112 & 133 & 131 & 125 \\
\hline & 156 & 85.2 & 83.0 & 80.0 \\
\hline & 216 & 88.0 & 90.4 & 90.2 \\
\hline \multirow[t]{9}{*}{ 2-Propenenitrile } & 0 & 102 & 104 & 93.6 \\
\hline & 14 & 100 & 101 & 103 \\
\hline & 28 & 85.8 & 92.5 & 93.8 \\
\hline & 37 & 104 & 105 & 104 \\
\hline & 47 & 105 & 106 & 106 \\
\hline & 56 & 96.0 & 110 & 104 \\
\hline & 112 & 109 & 112 & 109 \\
\hline & 156 & 101 & 102 & 103 \\
\hline & 216 & 85.5 & 92.5 & 92.5 \\
\hline
\end{tabular}


Table 5. Percent-recovery data for continuing calibration verification standards (CCVS) for day 0 through day 216 - Continued

[IUPAC, International Union of Pure and Applied Chemistry]

\begin{tabular}{|c|c|c|c|c|}
\hline \multirow{2}{*}{ IUPAC compound name } & \multirow{2}{*}{ Preparation day } & \multicolumn{3}{|c|}{ Replicate CCVS, in percentage of recovery } \\
\hline & & 1 & 2 & 3 \\
\hline \multicolumn{5}{|c|}{ Target analytes-Continued } \\
\hline \multirow[t]{9}{*}{$n$-Propylbenzene } & 0 & 103 & 103 & 96.4 \\
\hline & 14 & 103 & 99.2 & 96.7 \\
\hline & 28 & 101 & 101 & 101 \\
\hline & 37 & 103 & 102 & 101 \\
\hline & 47 & 104 & 103 & 103 \\
\hline & 56 & 96.9 & 100 & 94.7 \\
\hline & 112 & 101 & 97.8 & 99.3 \\
\hline & 156 & 99.2 & 93.1 & 99.7 \\
\hline & 216 & 102 & 97.0 & 101 \\
\hline \multirow[t]{9}{*}{ Tetrachloroethene } & 0 & 102 & 100 & 96.4 \\
\hline & 14 & 99.8 & 99.8 & 96.3 \\
\hline & 28 & 106 & 104 & 103 \\
\hline & 37 & 103 & 98.6 & 97.9 \\
\hline & 47 & 99.8 & 99.0 & 98.1 \\
\hline & 56 & 94.4 & 97.4 & 93.5 \\
\hline & 112 & 90.5 & 86.9 & 87.3 \\
\hline & 156 & 101 & 96.9 & 98.3 \\
\hline & 216 & 94.0 & 92.1 & 87.4 \\
\hline \multirow[t]{9}{*}{ Tetrachloromethane } & 0 & 102 & 103 & 97.9 \\
\hline & 14 & 104 & 98.8 & 97.2 \\
\hline & 28 & 99.9 & 98.9 & 98.1 \\
\hline & 37 & 103 & 100 & 101 \\
\hline & 47 & 107 & 108 & 106 \\
\hline & 56 & 94.7 & 97.2 & 93.0 \\
\hline & 112 & 105 & 102 & 103 \\
\hline & 156 & 101 & 98.4 & 100 \\
\hline & 216 & 95.6 & 90.9 & 91.5 \\
\hline \multirow[t]{9}{*}{ Tribromomethane } & 0 & 104 & 106 & 94.0 \\
\hline & 14 & 94.6 & 100 & 102 \\
\hline & 28 & 84.4 & 86.4 & 87.2 \\
\hline & 37 & 107 & 121 & 118 \\
\hline & 47 & 128 & 130 & 130 \\
\hline & 56 & 88.2 & 98.3 & 97.5 \\
\hline & 112 & 74.6 & 71.1 & 69.6 \\
\hline & 156 & 93.2 & 87.3 & 91.6 \\
\hline & 216 & 87.0 & 86.1 & 85.3 \\
\hline
\end{tabular}


Table 5. Percent-recovery data for continuing calibration verification standards (CCVS) for day 0 through day 216-Continued

[IUPAC, International Union of Pure and Applied Chemistry]

\begin{tabular}{|c|c|c|c|c|}
\hline \multirow{2}{*}{ IUPAC compound name } & \multirow{2}{*}{ Preparation day } & \multicolumn{3}{|c|}{ Replicate CCVS, in percentage of recovery } \\
\hline & & 1 & 2 & 3 \\
\hline \multicolumn{5}{|c|}{ Target analytes-Continued } \\
\hline \multirow[t]{9}{*}{ 1,1,2-Trichloro-1,2,2-trifluoroethane } & 0 & 98.7 & 102 & 97.5 \\
\hline & 14 & 103 & 96.6 & 97.7 \\
\hline & 28 & 119 & 110 & 116 \\
\hline & 37 & 109 & 105 & 102 \\
\hline & 47 & 114 & 112 & 114 \\
\hline & 56 & 99.6 & 102 & 104 \\
\hline & 112 & 95.0 & 88.1 & 86.7 \\
\hline & 156 & 106 & 98.3 & 102 \\
\hline & 216 & 86.1 & 83.6 & 82.0 \\
\hline \multirow[t]{9}{*}{ 1,2,3-Trichlorobenzene } & 0 & 94.8 & 95.8 & 87.6 \\
\hline & 14 & 97.3 & 99.6 & 102 \\
\hline & 28 & 95.0 & 100 & 103 \\
\hline & 37 & 99.2 & 95.7 & 102 \\
\hline & 47 & 107 & 113 & 113 \\
\hline & 56 & 92.4 & 94.4 & 102 \\
\hline & 112 & 88.6 & 86.1 & 87.2 \\
\hline & 156 & 59.2 & 53.4 & 89.4 \\
\hline & 216 & 96.7 & 101 & 108 \\
\hline \multirow[t]{9}{*}{ 1,2,4-Trichlorobenzene } & 0 & 96.3 & 98.7 & 90.5 \\
\hline & 14 & 96.5 & 97.3 & 98.2 \\
\hline & 28 & 95.4 & 98.6 & 99.0 \\
\hline & 37 & 99.9 & 92.7 & 99.5 \\
\hline & 47 & 109 & 109 & 110 \\
\hline & 56 & 89.5 & 93.2 & 103 \\
\hline & 112 & 88.5 & 82.9 & 84.3 \\
\hline & 156 & 60.5 & 51.5 & 88.2 \\
\hline & 216 & 99.8 & 99.0 & 110 \\
\hline \multirow[t]{9}{*}{ 1,1,1-Trichloroethane } & 0 & 101 & 101 & 96.3 \\
\hline & 14 & 99.9 & 97.7 & 95.6 \\
\hline & 28 & 102 & 102 & 102 \\
\hline & 37 & 102 & 98.2 & 98.8 \\
\hline & 47 & 103 & 101 & 102 \\
\hline & 56 & 95.3 & 97.6 & 94.2 \\
\hline & 112 & 104 & 101 & 102 \\
\hline & 156 & 102 & 99.0 & 101 \\
\hline & 216 & 94.9 & 90.2 & 88.7 \\
\hline
\end{tabular}


Table 5. Percent-recovery data for continuing calibration verification standards (CCVS) for day 0 through day 216-Continued

[IUPAC, International Union of Pure and Applied Chemistry]

\begin{tabular}{|c|c|c|c|c|}
\hline \multirow{2}{*}{ IUPAC compound name } & \multirow{2}{*}{ Preparation day } & \multicolumn{3}{|c|}{ Replicate CCVS, in percentage of recovery } \\
\hline & & 1 & 2 & 3 \\
\hline \multicolumn{5}{|c|}{ Target analytes-Continued } \\
\hline \multirow[t]{9}{*}{ 1,1,2-Trichloroethane } & 0 & 99.4 & 102 & 92.9 \\
\hline & 14 & 98.5 & 102 & 102 \\
\hline & 28 & 90.5 & 94.5 & 92.4 \\
\hline & 37 & 99.6 & 101 & 102 \\
\hline & 47 & 103 & 105 & 103 \\
\hline & 56 & 91.9 & 99.9 & 98.0 \\
\hline & 112 & 98.7 & 93.6 & 97.3 \\
\hline & 156 & 101 & 94.7 & 95.6 \\
\hline & 216 & 98.5 & 91.3 & 93.1 \\
\hline \multirow[t]{9}{*}{ Trichloroethene } & 0 & 98.9 & 100 & 94.5 \\
\hline & 14 & 101 & 97.6 & 95.5 \\
\hline & 28 & 103 & 99.2 & 102 \\
\hline & 37 & 104 & 99.8 & 97.0 \\
\hline & 47 & 100 & 101 & 102 \\
\hline & 56 & 95.1 & 99.3 & 94.5 \\
\hline & 112 & 103 & 100 & 102 \\
\hline & 156 & 100 & 97.3 & 100 \\
\hline & 216 & 95.6 & 93.7 & 94.9 \\
\hline \multirow[t]{9}{*}{ Trichlorofluoromethane } & 0 & 99.3 & 105 & 100 \\
\hline & 14 & 104 & 94.4 & 94.5 \\
\hline & 28 & 121 & 112 & 119 \\
\hline & 37 & 106 & 96.2 & 98.1 \\
\hline & 47 & 109 & 98.5 & 104 \\
\hline & 56 & 98.6 & 91.3 & 94.4 \\
\hline & 112 & 110 & 103 & 102 \\
\hline & 156 & 106 & 100 & 107 \\
\hline & 216 & 80.8 & 75.1 & 73.5 \\
\hline \multirow[t]{9}{*}{ Trichloromethane } & 0 & 103 & 102 & 89.5 \\
\hline & 14 & 99.1 & 98.4 & 97.0 \\
\hline & 28 & 100 & 100 & 103 \\
\hline & 37 & 101 & 101 & 101 \\
\hline & 47 & 105 & 105 & 106 \\
\hline & 56 & 95.1 & 97.6 & 96.1 \\
\hline & 112 & 108 & 104 & 106 \\
\hline & 156 & 101 & 97.6 & 100 \\
\hline & 216 & 96.0 & 93.7 & 90.0 \\
\hline
\end{tabular}


Table 5. Percent-recovery data for continuing calibration verification standards (CCVS) for day 0 through day 216 - Continued

[IUPAC, International Union of Pure and Applied Chemistry]

\begin{tabular}{|c|c|c|c|c|}
\hline \multirow{2}{*}{ IUPAC compound name } & \multirow{2}{*}{ Preparation day } & \multicolumn{3}{|c|}{ Replicate CCVS, in percentage of recovery } \\
\hline & & 1 & 2 & 3 \\
\hline \multicolumn{5}{|c|}{ Target analytes-Continued } \\
\hline \multirow[t]{9}{*}{ 1,2,3-Trichloropropane } & 0 & 102 & 105 & 94.0 \\
\hline & 14 & 98.2 & 99.8 & 102 \\
\hline & 28 & 85.2 & 87.6 & 89.7 \\
\hline & 37 & 97.4 & 102 & 102 \\
\hline & 47 & 105 & 107 & 106 \\
\hline & 56 & 93.2 & 106 & 104 \\
\hline & 112 & 109 & 97.5 & 106 \\
\hline & 156 & 99.4 & 89.5 & 96.4 \\
\hline & 216 & 93.0 & 91.1 & 93.9 \\
\hline \multirow[t]{10}{*}{ 1,2,4-Trimethylbenzene } & 0 & 99.8 & 101 & 95.8 \\
\hline & 14 & 101 & 99.3 & 97.9 \\
\hline & 28 & 102 & 101 & 99.3 \\
\hline & 37 & 104 & 98.1 & 101 \\
\hline & 47 & 104 & 105 & 104 \\
\hline & 56 & 95.1 & 97.5 & 95.4 \\
\hline & 112 & 102 & 97.4 & 98.8 \\
\hline & 156 & 85.0 & 73.9 & 96.5 \\
\hline & 216 & 109 & 108 & 108 \\
\hline & \multicolumn{2}{|c|}{ Other analytes } & & \\
\hline \multirow[t]{9}{*}{ Bromobenzene } & 0 & 102 & 101 & 93.7 \\
\hline & 14 & 98.5 & 101 & 101 \\
\hline & 28 & 99.0 & 99.6 & 97.9 \\
\hline & 37 & 102 & 102 & 104 \\
\hline & 47 & 104 & 106 & 106 \\
\hline & 56 & 93.2 & 100 & 98.5 \\
\hline & 112 & 87.4 & 85.3 & 84.6 \\
\hline & 156 & 99.8 & 93.5 & 98.0 \\
\hline & 216 & 97.3 & 92.8 & 90.9 \\
\hline \multirow[t]{9}{*}{ Bromochloromethane } & 0 & 100 & 105 & 95.2 \\
\hline & 14 & 99.8 & 99.9 & 99.0 \\
\hline & 28 & 99.1 & 98.6 & 99.6 \\
\hline & 37 & 102 & 104 & 102 \\
\hline & 47 & 105 & 105 & 106 \\
\hline & 56 & 94.0 & 101 & 99.8 \\
\hline & 112 & 97.7 & 93.0 & 96.4 \\
\hline & 156 & 105 & 97.6 & 100 \\
\hline & 216 & 93.6 & 92.4 & 89.1 \\
\hline
\end{tabular}


Table 5. Percent-recovery data for continuing calibration verification standards (CCVS) for day 0 through day 216-Continued

[IUPAC, International Union of Pure and Applied Chemistry]

\begin{tabular}{|c|c|c|c|c|}
\hline \multirow{2}{*}{ IUPAC compound name } & \multirow{2}{*}{ Preparation day } & \multicolumn{3}{|c|}{ Replicate CCVS, in percentage of recovery } \\
\hline & & 1 & 2 & 3 \\
\hline \multicolumn{5}{|c|}{ Other analytes-Continued } \\
\hline \multirow[t]{9}{*}{ 2-Butanone } & 0 & 101 & 102 & 90.5 \\
\hline & 14 & 98.1 & 100 & 105 \\
\hline & 28 & 79.1 & 86.9 & 90.8 \\
\hline & 37 & 99.7 & 106 & 103 \\
\hline & 47 & 103 & 103 & 102 \\
\hline & 56 & 91.1 & 98.5 & 103 \\
\hline & 112 & 122 & 115 & 117 \\
\hline & 156 & 99.6 & 95.1 & 95.3 \\
\hline & 216 & 90.6 & 90.8 & 90.1 \\
\hline \multirow[t]{9}{*}{ Carbon disulfide } & 0 & 108 & 111 & 106 \\
\hline & 14 & 104 & 91.8 & 93.0 \\
\hline & 28 & 110 & 102 & 111 \\
\hline & 37 & 106 & 102 & 99.3 \\
\hline & 47 & 116 & 107 & 115 \\
\hline & 56 & 98.3 & 89.0 & 94.4 \\
\hline & 112 & 115 & 103 & 108 \\
\hline & 156 & 105 & 92.8 & 102 \\
\hline & 216 & 85.0 & 82.6 & 91.1 \\
\hline \multirow[t]{9}{*}{ 1-Chloro-2-methylbenzene } & 0 & 102 & 102 & 97.0 \\
\hline & 14 & 101 & 100 & 97.5 \\
\hline & 28 & 101 & 98.8 & 99.5 \\
\hline & 37 & 103 & 101 & 101 \\
\hline & 47 & 102 & 102 & 103 \\
\hline & 56 & 94.7 & 99.5 & 96.9 \\
\hline & 112 & 100 & 97.4 & 97.8 \\
\hline & 156 & 103 & 98.2 & 104 \\
\hline & 216 & 98.3 & 96.2 & 93.2 \\
\hline \multirow[t]{9}{*}{ 1-Chloro-4-methylbenzene } & 0 & 102 & 103 & 92.8 \\
\hline & 14 & 100 & 101 & 96.5 \\
\hline & 28 & 100 & 98.3 & 96.1 \\
\hline & 37 & 103 & 99.1 & 99.8 \\
\hline & 47 & 101 & 102 & 102 \\
\hline & 56 & 96.2 & 101 & 95.9 \\
\hline & 112 & 101 & 95.9 & 96.9 \\
\hline & 156 & 98.6 & 92.4 & 99.6 \\
\hline & 216 & 101 & 98.2 & 98.5 \\
\hline
\end{tabular}


Table 5. Percent-recovery data for continuing calibration verification standards (CCVS) for day 0 through day $216-$ Continued

[IUPAC, International Union of Pure and Applied Chemistry]

\begin{tabular}{|c|c|c|c|c|}
\hline \multirow{2}{*}{ IUPAC compound name } & \multirow{2}{*}{ Preparation day } & \multicolumn{3}{|c|}{ Replicate CCVS, in percentage of recovery } \\
\hline & & 1 & 2 & 3 \\
\hline \multicolumn{5}{|c|}{ Other analytes - Continued } \\
\hline \multirow[t]{9}{*}{ 3-Chloro-1-propene } & 0 & 106 & 109 & 102 \\
\hline & 14 & 101 & 97.3 & 96.4 \\
\hline & 28 & 105 & 102 & 109 \\
\hline & 37 & 106 & 102 & 99.2 \\
\hline & 47 & 109 & 107 & 113 \\
\hline & 56 & 99.3 & 97.8 & 94.8 \\
\hline & 112 & 117 & 110 & 112 \\
\hline & 156 & 92.9 & 90.0 & 93.1 \\
\hline & 216 & 118 & 118 & 120 \\
\hline \multirow[t]{9}{*}{ Dibromomethane } & 0 & 101 & 102 & 92.1 \\
\hline & 14 & 101 & 102 & 102 \\
\hline & 28 & 95.0 & 97.8 & 98.9 \\
\hline & 37 & 101 & 102 & 102 \\
\hline & 47 & 104 & 106 & 107 \\
\hline & 56 & 94.7 & 102 & 95.9 \\
\hline & 112 & 103 & 99.0 & 100 \\
\hline & 156 & 101 & 95.8 & 99.4 \\
\hline & 216 & 94.0 & 92.0 & 91.3 \\
\hline \multirow[t]{9}{*}{ trans-1,4-Dichloro-2-butene } & 0 & 105 & 107 & 96.3 \\
\hline & 14 & 99.7 & 103 & 104 \\
\hline & 28 & 80.6 & 85.4 & 87.9 \\
\hline & 37 & 101 & 105 & 103 \\
\hline & 47 & 108 & 118 & 120 \\
\hline & 56 & 90.9 & 103 & 102 \\
\hline & 112 & 118 & 112 & 115 \\
\hline & 156 & 106 & 97.5 & 103 \\
\hline & 216 & 102 & 105 & 106 \\
\hline \multirow[t]{9}{*}{ 1,3-Dichloropropane } & 0 & 101 & 103 & 93.1 \\
\hline & 14 & 98.0 & 101 & 101 \\
\hline & 28 & 91.6 & 93.5 & 95.9 \\
\hline & 37 & 103 & 103 & 104 \\
\hline & 47 & 105 & 105 & 108 \\
\hline & 56 & 92.5 & 98.2 & 97.5 \\
\hline & 112 & 110 & 104 & 105 \\
\hline & 156 & 102 & 95.3 & 99.0 \\
\hline & 216 & 92.4 & 90.6 & 88.8 \\
\hline
\end{tabular}


Table 5. Percent-recovery data for continuing calibration verification standards (CCVS) for day 0 through day 216-Continued

[IUPAC, International Union of Pure and Applied Chemistry]

\begin{tabular}{|c|c|c|c|c|}
\hline \multirow{2}{*}{ IUPAC compound name } & \multirow{2}{*}{ Preparation day } & \multicolumn{3}{|c|}{ Replicate CCVS, in percentage of recovery } \\
\hline & & 1 & 2 & 3 \\
\hline \multicolumn{5}{|c|}{ Other analytes-Continued } \\
\hline \multirow[t]{9}{*}{ 2,2-Dichloropropane } & 0 & 93.1 & 96.4 & 96.3 \\
\hline & 14 & 98.9 & 96.0 & 87.8 \\
\hline & 28 & 102 & 97.8 & 97.7 \\
\hline & 37 & 102 & 91.4 & 94.0 \\
\hline & 47 & 99.2 & 95.5 & 99.4 \\
\hline & 56 & 94.2 & 92.1 & 89.7 \\
\hline & 112 & 109 & 102 & 97.8 \\
\hline & 156 & 103 & 96.3 & 97.2 \\
\hline & 216 & 94.0 & 88.4 & 89.7 \\
\hline \multirow[t]{9}{*}{ 1,1-Dichloropropene } & 0 & 101 & 104 & 97.3 \\
\hline & 14 & 99.6 & 99.7 & 95.7 \\
\hline & 28 & 105 & 102 & 105 \\
\hline & 37 & 103 & 100 & 99.4 \\
\hline & 47 & 102 & 103 & 103 \\
\hline & 56 & 95.1 & 96.4 & 94.6 \\
\hline & 112 & 110 & 108 & 108 \\
\hline & 156 & 101 & 96.9 & 100 \\
\hline & 216 & 95.4 & 90.8 & 90.5 \\
\hline \multirow[t]{9}{*}{ (1,1-Dimethylethyl)benzene } & 0 & 104 & 102 & 98.3 \\
\hline & 14 & 102 & 99.9 & 97.6 \\
\hline & 28 & 101 & 99.7 & 98.4 \\
\hline & 37 & 105 & 102 & 102 \\
\hline & 47 & 104 & 103 & 103 \\
\hline & 56 & 95.5 & 101 & 95.9 \\
\hline & 112 & 103 & 99.1 & 100 \\
\hline & 156 & 96.1 & 90.4 & 99.5 \\
\hline & 216 & 106 & 104 & 103 \\
\hline \multirow[t]{9}{*}{ 1,4-Epoxybutane } & 0 & 98.8 & 103 & 90.0 \\
\hline & 14 & 102 & 99.9 & 106 \\
\hline & 28 & 87.0 & 94.8 & 96.0 \\
\hline & 37 & 104 & 106 & 111 \\
\hline & 47 & 106 & 110 & 109 \\
\hline & 56 & 92.7 & 101 & 103 \\
\hline & 112 & 115 & 110 & 115 \\
\hline & 156 & 100 & 98.0 & 101 \\
\hline & 216 & 90.4 & 87.0 & 89.0 \\
\hline
\end{tabular}


Table 5. Percent-recovery data for continuing calibration verification standards (CCVS) for day 0 through day 216-Continued

[IUPAC, International Union of Pure and Applied Chemistry]

\begin{tabular}{|c|c|c|c|c|}
\hline \multirow{2}{*}{ IUPAC compound name } & \multirow{2}{*}{ Preparation day } & \multicolumn{3}{|c|}{ Replicate CCVS, in percentage of recovery } \\
\hline & & 1 & 2 & 3 \\
\hline \multicolumn{5}{|c|}{ Other analytes-Continued } \\
\hline \multirow[t]{9}{*}{ 1-Ethyl-2-methylbenzene } & 0 & 103 & 101 & 97.4 \\
\hline & 14 & 103 & 101 & 98.0 \\
\hline & 28 & 100 & 100 & 99.3 \\
\hline & 37 & 104 & 99.6 & 101 \\
\hline & 47 & 103 & 104 & 104 \\
\hline & 56 & 96.9 & 100 & 96.6 \\
\hline & 112 & 106 & 102 & 104 \\
\hline & 156 & 96.9 & 89.2 & 101 \\
\hline & 216 & 105 & 104 & 102 \\
\hline \multirow[t]{9}{*}{ Ethyl 2-methyl-2-propenoate } & 0 & 100 & 102 & 89.3 \\
\hline & 14 & 100 & 104 & 104 \\
\hline & 28 & 87.5 & 91.8 & 92.9 \\
\hline & 37 & 101 & 102 & 103 \\
\hline & 47 & 105 & 110 & 106 \\
\hline & 56 & 92.8 & 103 & 106 \\
\hline & 112 & 113 & 110 & 117 \\
\hline & 156 & 98.0 & 95.0 & 96.2 \\
\hline & 216 & 87.8 & 86.8 & 85.0 \\
\hline \multirow[t]{9}{*}{ 2-Hexanone } & 0 & 102 & 103 & 91.0 \\
\hline & 14 & 99.0 & 103 & 108 \\
\hline & 28 & 82.1 & 88.8 & 91.6 \\
\hline & 37 & 102 & 108 & 107 \\
\hline & 47 & 106 & 109 & 110 \\
\hline & 56 & 93.4 & 103 & 106 \\
\hline & 112 & 119 & 113 & 118 \\
\hline & 156 & 100 & 96.6 & 98.9 \\
\hline & 216 & 85.7 & 88.8 & 90.7 \\
\hline \multirow[t]{9}{*}{ Iodomethane } & 0 & 122 & 124 & 111 \\
\hline & 14 & 102 & 99.9 & 92.0 \\
\hline & 28 & 97.8 & 93.8 & 98.0 \\
\hline & 37 & 103 & 104 & 104 \\
\hline & 47 & 107 & 106 & 108 \\
\hline & 56 & 95.4 & 88.6 & 78.3 \\
\hline & 112 & 85.8 & 94.3 & 91.5 \\
\hline & 156 & 131 & 122 & 128 \\
\hline & 216 & 89.8 & 90.3 & 88.9 \\
\hline
\end{tabular}


Table 5. Percent-recovery data for continuing calibration verification standards (CCVS) for day 0 through day 216-Continued

[IUPAC, International Union of Pure and Applied Chemistry]

\begin{tabular}{|c|c|c|c|c|}
\hline \multirow{2}{*}{ IUPAC compound name } & \multirow{2}{*}{ Preparation day } & \multicolumn{3}{|c|}{ Replicate CCVS, in percentage of recovery } \\
\hline & & 1 & 2 & 3 \\
\hline \multicolumn{5}{|c|}{ Other analytes-Continued } \\
\hline \multirow[t]{9}{*}{ 1-Isopropyl-4-methylbenzene } & 0 & 103 & 102 & 99.3 \\
\hline & 14 & 102 & 99.6 & 97.0 \\
\hline & 28 & 104 & 103 & 103 \\
\hline & 37 & 106 & 101 & 100 \\
\hline & 47 & 104 & 106 & 105 \\
\hline & 56 & 96.1 & 98.5 & 94.6 \\
\hline & 112 & 108 & 104 & 102 \\
\hline & 156 & 83.7 & 72.3 & 98.2 \\
\hline & 216 & 117 & 122 & 122 \\
\hline \multirow[t]{9}{*}{ Methyl 2-methyl-2-propenoate } & 0 & 101 & 102 & 89.4 \\
\hline & 14 & 96.6 & 103 & 104 \\
\hline & 28 & 84.5 & 90.5 & 90.0 \\
\hline & 37 & 102 & 103 & 104 \\
\hline & 47 & 104 & 107 & 108 \\
\hline & 56 & 91.5 & 98.5 & 100 \\
\hline & 112 & 114 & 110 & 108 \\
\hline & 156 & 102 & 97.5 & 101 \\
\hline & 216 & 90.0 & 92.0 & 92.0 \\
\hline \multirow[t]{9}{*}{ 4-Methyl-2-pentanone } & 0 & 101 & 104 & 90.1 \\
\hline & 14 & 98.9 & 103 & 108 \\
\hline & 28 & 83.8 & 91.1 & 92.6 \\
\hline & 37 & 101 & 105 & 105 \\
\hline & 47 & 105 & 107 & 108 \\
\hline & 56 & 94.2 & 100 & 104 \\
\hline & 112 & 112 & 110 & 114 \\
\hline & 156 & 97.8 & 94.6 & 98.4 \\
\hline & 216 & 89.8 & 89.5 & 89.6 \\
\hline \multirow[t]{9}{*}{ 2-Methyl-2-propenenitrile } & 0 & 101 & 101 & 94.1 \\
\hline & 14 & 97.0 & 105 & 107 \\
\hline & 28 & 85.5 & 90.0 & 90.0 \\
\hline & 37 & 105 & 106 & 108 \\
\hline & 47 & 110 & 109 & 108 \\
\hline & 56 & 93.5 & 102 & 104 \\
\hline & 112 & 116 & 110 & 111 \\
\hline & 156 & 101 & 98.0 & 97.0 \\
\hline & 216 & 92.5 & 98.0 & 95.0 \\
\hline
\end{tabular}


Table 5. Percent-recovery data for continuing calibration verification standards (CCVS) for day 0 through day 216-Continued

[IUPAC, International Union of Pure and Applied Chemistry]

\begin{tabular}{|c|c|c|c|c|}
\hline \multirow{2}{*}{ IUPAC compound name } & \multirow{2}{*}{ Preparation day } & \multicolumn{3}{|c|}{ Replicate CCVS, in percentage of recovery } \\
\hline & & 1 & 2 & 3 \\
\hline \multicolumn{5}{|c|}{ Other analytes-Continued } \\
\hline \multirow[t]{9}{*}{ Methyl-2-propenoate } & 0 & 99.6 & 102 & 87.4 \\
\hline & 14 & 99.2 & 98.8 & 100 \\
\hline & 28 & 80.0 & 84.0 & 85.5 \\
\hline & 37 & 100 & 99.5 & 102 \\
\hline & 47 & 106 & 103 & 108 \\
\hline & 56 & 88.5 & 100 & 102 \\
\hline & 112 & 117 & 111 & 112 \\
\hline & 156 & 104 & 103 & 100 \\
\hline & 216 & 88.0 & 92.0 & 86.0 \\
\hline \multirow[t]{9}{*}{ (1-Methylpropyl)benzene } & 0 & 104 & 103 & 98.9 \\
\hline & 14 & 102 & 99.8 & 96.7 \\
\hline & 28 & 102 & 99.1 & 101 \\
\hline & 37 & 104 & 101 & 101 \\
\hline & 47 & 102 & 104 & 104 \\
\hline & 56 & 95.9 & 99.3 & 95.7 \\
\hline & 112 & 103 & 100 & 101 \\
\hline & 156 & 92.4 & 82.3 & 97.3 \\
\hline & 216 & 108 & 110 & 110 \\
\hline \multirow[t]{9}{*}{ 1,1'-Oxybisethane } & 0 & 104 & 104 & 94.0 \\
\hline & 14 & 97.6 & 98.2 & 100 \\
\hline & 28 & 92.6 & 98.0 & 101 \\
\hline & 37 & 102 & 99.3 & 98.7 \\
\hline & 47 & 106 & 105 & 103 \\
\hline & 56 & 93.6 & 96.7 & 101 \\
\hline & 112 & 138 & 125 & 126 \\
\hline & 156 & 98.0 & 88.3 & 94.4 \\
\hline & 216 & 81.4 & 85.6 & 86.8 \\
\hline \multirow[t]{9}{*}{ 2-Propanone } & 0 & 104 & 104 & 92.5 \\
\hline & 14 & 95.6 & 98.6 & 101 \\
\hline & 28 & 87.6 & 91.2 & 97.3 \\
\hline & 37 & 98.3 & 103 & 104 \\
\hline & 47 & 98.5 & 98.1 & 101 \\
\hline & 56 & 93.3 & 99.8 & 109 \\
\hline & 112 & 131 & 130 & 133 \\
\hline & 156 & 135 & 118 & 131 \\
\hline & 216 & 87.9 & 90.2 & 94.2 \\
\hline
\end{tabular}


Table 5. Percent-recovery data for continuing calibration verification standards (CCVS) for day 0 through day 216 - Continued

[IUPAC, International Union of Pure and Applied Chemistry]

\begin{tabular}{|c|c|c|c|c|}
\hline \multirow{2}{*}{ IUPAC compound name } & \multirow{2}{*}{ Preparation day } & \multicolumn{3}{|c|}{ Replicate CCVS, in percentage of recovery } \\
\hline & & 1 & 2 & 3 \\
\hline \multicolumn{5}{|c|}{ Other analytes-Continued } \\
\hline \multirow[t]{9}{*}{ 1,1,1,2-Tetrachloroethane } & 0 & 102 & 101 & 94.8 \\
\hline & 14 & 99.0 & 100 & 98.0 \\
\hline & 28 & 97.2 & 96.4 & 95.5 \\
\hline & 37 & 102 & 101 & 101 \\
\hline & 47 & 105 & 104 & 104 \\
\hline & 56 & 94.8 & 97.4 & 96.7 \\
\hline & 112 & 94.7 & 91.8 & 91.8 \\
\hline & 156 & 98.2 & 94.1 & 99.5 \\
\hline & 216 & 94.5 & 94.4 & 90.8 \\
\hline \multirow[t]{9}{*}{ 1,1,2,2-Tetrachloroethane } & 0 & 103 & 105 & 91.3 \\
\hline & 14 & 98.4 & 99.5 & 105 \\
\hline & 28 & 79.6 & 91.5 & 89.0 \\
\hline & 37 & 99.4 & 103 & 105 \\
\hline & 47 & 106 & 111 & 110 \\
\hline & 56 & 89.2 & 101 & 100 \\
\hline & 112 & 100 & 96.5 & 98.9 \\
\hline & 156 & 99.4 & 94.6 & 97.6 \\
\hline & 216 & 92.4 & 93.3 & 92.4 \\
\hline \multirow[t]{9}{*}{ 1,2,3,4-Tetramethylbenzene } & 0 & 88.6 & 89.3 & 86.6 \\
\hline & 14 & 96.4 & 92.2 & 97.1 \\
\hline & 28 & 94.1 & 99.9 & 97.4 \\
\hline & 37 & 103 & 87.5 & 96.2 \\
\hline & 47 & 113 & 109 & 108 \\
\hline & 56 & 92.5 & 85.1 & 96.6 \\
\hline & 112 & 109 & 104 & 104 \\
\hline & 156 & 49.2 & 47.4 & 89.7 \\
\hline & 216 & 105 & 102 & 106 \\
\hline \multirow[t]{9}{*}{ 1,2,3,5-Tetramethylbenzene } & 0 & 95.4 & 93.8 & 90.8 \\
\hline & 14 & 100 & 97.2 & 98.5 \\
\hline & 28 & 102 & 106 & 107 \\
\hline & 37 & 102 & 89.4 & 95.9 \\
\hline & 47 & 106 & 106 & 105 \\
\hline & 56 & 95.1 & 89.8 & 97.5 \\
\hline & 112 & 120 & 109 & 114 \\
\hline & 156 & 59.1 & 52.8 & 93.0 \\
\hline & 216 & 104 & 101 & 106 \\
\hline
\end{tabular}


Table 5. Percent-recovery data for continuing calibration verification standards (CCVS) for day 0 through day 216-Continued

[IUPAC, International Union of Pure and Applied Chemistry]

\begin{tabular}{|c|c|c|c|c|}
\hline \multirow{2}{*}{ IUPAC compound name } & \multirow{2}{*}{ Preparation day } & \multicolumn{3}{|c|}{ Replicate CCVS, in percentage of recovery } \\
\hline & & 1 & 2 & 3 \\
\hline \multicolumn{5}{|c|}{ Other analytes-Continued } \\
\hline \multirow[t]{9}{*}{ 1,2,3-Trimethylbenzene } & 0 & 101 & 101 & 96.6 \\
\hline & 14 & 100 & 99.2 & 99.2 \\
\hline & 28 & 98.6 & 99.2 & 99.6 \\
\hline & 37 & 102 & 98.6 & 101 \\
\hline & 47 & 104 & 108 & 106 \\
\hline & 56 & 93.7 & 99.1 & 96.2 \\
\hline & 112 & 108 & 102 & 104 \\
\hline & 156 & 82.3 & 71.4 & 94.4 \\
\hline & 216 & 109 & 109 & 108 \\
\hline \multirow[t]{9}{*}{ 1,3,5-Trimethylbenzene } & 0 & 103 & 102 & 97.4 \\
\hline & 14 & 101 & 102 & 99.0 \\
\hline & 28 & 100 & 101 & 101 \\
\hline & 37 & 104 & 100 & 101 \\
\hline & 47 & 105 & 105 & 104 \\
\hline & 56 & 96.0 & 99.2 & 94.9 \\
\hline & 112 & 102 & 98.3 & 99.4 \\
\hline & 156 & 96.1 & 88.0 & 98.8 \\
\hline & 216 & 106 & 104 & 104 \\
\hline
\end{tabular}

